ISSN: 1808-5385

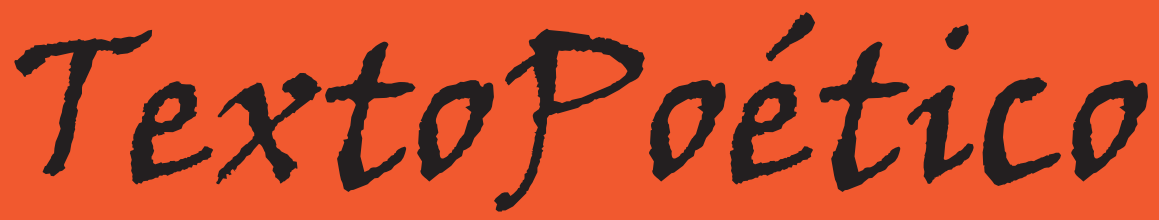

REVISTA DO GT TEORIA DO TEXTO POÉTICO (ANPOLL) ANO XI - N. 17 - 2. SEMESTRE/2014 


\section{TextoPoético}

Revista do GT Teoria do Texto Poético

ISSN: 1808-5385

\section{Coordenação}

Diana Junkes Bueno Martha

Ida Maria Santos Ferreira Alves

\section{Editora resposável}

Diana Junkes Martha Toneto

\section{Co-editora resposável}

Ida Maria Santos Ferreira Alves

\section{Comitê Editorial}

Diana Junkes Martha Toneto (UNESP/ São José do Rio Preto)

Ida Maria Santos Ferreira Alves (UFF)

Adalberto Luis Vicente (UNESP/Araraquara)

Antonio Donizeti da Cruz (UNIOESTE/Marechal Cândido Rondon)

Elaine Cristina Cintra (UFU)

Solange Fiuza Cardoso Yokozawa (UFG/Goiânia)

Wilton José Marques (UFSCar-UNESP/Araraquara)

\section{Conselho Editorial}

Albertina Vicentini Assumpção (UCG)

Ana Maria Lisboa de Mello (UFRGS)

Ângela Maria Dias (UFF)

Enivalda Nunes Freitas e Souza (UFU)

Fernando Cabral Martins (Universidade Nova de Lisboa)

Francis Uteza (Université Paul Valéry - Montpellier)

Ida Maria Santos Ferreira Alves (UFF)

Jaime Ginzburg (USP)

Marcos Siscar (IEL/UNICAMP)

Maria Adélia Menegazzo (UFMS)

Maria Zaira Turchi (UFG/Goiânia)

Paula Glenadel (UFF)

Vera Lúcia de Oliveira (Università di Perugia)

\section{Revisão}

Talita Serpa e João Paulo Vani

\section{Projeto Gráfico e Diagramação}

HN Editora 


\section{SUMÁRIO}

\section{DOSSIÊ}

Pessoa e Platão: alguns contatos

Bernardo Nascimento de AMORIM

Édipo hermeneuta - a dimensão poético-ontológica da tragédia

\section{David Fontes}

Katia Rose Oliveira de Pinho

Visões do Oriente e dos Impérios; Théophile Gautier e

Giuseppe Verdi

\section{Celina Maria Moreira de MELLO}

A escritura de um efêmero: aspectos da releitura da obra

baudelairiana em Une histoire de bleu, de Jean-Michel Maulpoix

\section{Erica MILANEZE}

Poesia Impressionista no Simbolismo Brasileiro: Maranhão

Sobrinho, Pedro Kilkerry e Ernani Rosas

Jairo Nogueira LUNA

Um simbolista na periferia do capitalismo: sonho, transcendência e queda na poética de Cruz e Sousa Paula Regina SIEGA 
Manoel de Barros é um leitor dos Sermões de Vieira?

Ilca Vieira de OLIVEIRA

Sujeito em trânsito: filiação e ruptura ao Modernismo em

em Armando Freitas Filho

Paulo ANDRADE

Poetic experience and cultural knowledge in P. K. Page’s

"Brazilian Fazenda"

Sigrid RENAUX

Alguma Poesia e a Técnica

209

João Batista SANTIAGo SOBRINHO

\section{VÁRIA}

Imagens poéticas e pictóricas das Cataratas do Iguaçu e

Sete Quedas: poesia e memória

\section{Antonio Donizeti da CRUZ}

Escrevendo-se mulher: um diálogo entre a crítica feminista 253 a lírica de Maria Teresa Horta

Natália Salomé de SOUZA Vinícius Carvalho PEREIRA 


\title{
PESSOA E PLATÃO: ALGUNS CONTATOS
}

\section{PESSOA AND PLATO: SOME CONNECTIONS}

Bernardo Nascimento de AMORIM ${ }^{1}$

\begin{abstract}
RESUMO: 0 texto que ora se publica é o resultado da vontade de aproximação entre dois autores de campos diferentes, um poeta e um filósofo, separados por mais de dois milênios de história. Em Platão, o fundador da Academia, vislumbrase o nascimento da filosofia ocidental, ou, pelo menos, como muito se tem dito, da metafísica do Ocidente. Em Fernando Pessoa, a metafísica, como muitas outras ideias e posições, será objeto de fundo e dramático questionamento, envolvendo a experiência subjetiva, a perspectiva do poeta lírico, em tempos modernos. 0 artigo focaliza alguns dos pontos de contato entre os dois autores, ressaltando atritos e afinidades, com a crença de que tal procedimento possa jogar luz à compreensão de questões que permanecem prementes no presente.
\end{abstract}

PALAVRAS-CHAVE: Fernando Pessoa. Platão. Poesia. Filosofia.

ABSTRACT: The text herein published is the result of the wish to bring closer two authors from different fields, a poet and a philosopher, separated by over two thousand years of

${ }^{1}$ Professor do Departamento de Letras do Instituto de Ciências Humanas e Sociais (ICHS) da Universidade Federal de Ouro Preto (UFOP). 
history. In Plato, the founder of the Academy, one witnesses the birth of western philosophy or at least, as it has often been said, of the western metaphysics. In Fernando Pessoa, the metaphysics, as several other ideas and positions, will be object of deep and dramatic questioning, involving the subjective experience - the perspective of the lyric poet - in modern times. The article intends to focus on some of the connections between the two authors, emphasizing frictions and affinities, believing that by doing so it may throw some light on the understanding of some issues that remain distressing in the present.

KEY-WORDS: Fernando Pessoa. Plato. Poetry. Philosophy.

0 primeiro momento do artigo, que logo revela o seu caráter fragmentário, o qual se fará acompanhar de movimentos de idas e vindas, como se verá, é apenas para se apresentar algo dito por Bernardo Soares, semi-heterônimo de Fernando Pessoa, que, nos escritos hoje reunidos no Livro do desassossego, significa de maneira singular palavras e expressões como "permanência" e "nunca mudar". É esta maneira que me servirá como indício de um posicionamento central, a partir do qual se desdobrarão as reflexões que aqui terão lugar. Diz Soares: "Não compreendo senão como uma espécie de falta de asseio esta inerte permanência em que jazo da minha mesma e igual vida, ficada como pó ou porcaria na superfície de nunca mudar." (PESSOA, 1999, p. 76).

II

Quando Platão (429-347 a. C.) concebeu A república, por volta do século IV antes de Cristo (375 ou 374 a. C.), Atenas tinha atravessado um momento culminante de crise, decorrente, segundo Benedito Nunes, de um processo de laicização de suas instituições, o qual 
teria como resultado a diminuição do prestígio daqueles que antes eram vistos como quem detinha o saber, sustentado pelo domínio de uma "palavra mágico-religiosa" (NUNES, 1999, p. 81). 0 tempo era o de uma transição que colocava em lados opostos um "pensamento reflexivo condicionado pela apreciação dialógica" (NUNES, 1999, p. 82), de que Sócrates e Platão seriam representantes, e um tipo mais antigo de conhecimento, embasado na "potência reveladora ambígua" (NUNES, 1999, p. 82) que as palavras alcançariam no mito e na poesia. Não mais seriam os adivinhos ou os poetas quem se imagina poder ter um acesso privilegiado à verdade, sendo capazes de ensiná-la aos outros, mas os filósofos, que, na república que se concebe, tornam-se, também, os legisladores.

0 que se encena, em $A$ república, seria uma persistente querela, incidindo sobre quem poderiam ser, em determinada comunidade, nas palavras de Maria da Penha Vilella-Petit, "os portadores de palavras essenciais” (VILELLA-PETIT, 2003, p. 53). Sócrates submete os dizeres dos poetas a questionamento com vistas a apontar e a esclarecer suas supostas deturpações, o seu afastamento tanto da verdade quanto da virtude. As interrogações, evidenciando quais seriam "os dois campos em confronto" (NUNES, 2010, p. 1), visariam a destronar os poetas da posição que ocupavam, em especial, no âmbito do magistério. A tal ponto chega a disputa que o filósofo, procurando consagrar "a superioridade hierárquica do filosófico sobre o poético" (NUNES, 1999, p. 2), afirma como a mais alta das artes das musas, justamente, "a arte do filósofo" (VILELLAPETIT, 2003, p. 61).

\section{III}

Nos momentos em que Fernando Pessoa procurou sistematizar uma espécie de hierarquia entre as artes, conforme o apontado por Georg Rudolf Lind (1970), filosofia e literatura, somadas à música, ocupam o lugar mais alto, pois seriam as artes que, além 
de exercer uma influência duradoura, libertariam o homem do domínio das sensações, da sensibilidade, contribuindo para o seu aperfeiçoamento, para uma "evolução do cérebro humano" (LIND, 1970, p. 246). Tais artes, chamadas de "artes abstratas" (LIND, 1970, p. 245), em oposição às "artes concretas" (LIND, 1970, p. 245), dentre as quais se contariam a dança, o teatro, a escultura, a pintura e a arquitetura, seriam destinadas a poucos, preenchendo e exigindo pré-requisitos raros, nomeadamente, a capacidade de "análise psicológica" (LIND, 1970, p. 248), a de "especulação metafísica" (LIND, 1970, p. 248) e a de "emoção abstrata" (LIND, 1970, p. 248). Aproximam-se, deste modo, no pensamento do autor, filosofia e poesia, artes igualmente capazes de abstração, operação racional que elevaria o indivíduo sobre os seus pares, afastando-o de certo "plebeísmo intelectual" (LIND, 1970, p. 249), e às quais se atribui uma forma de "missão civilizadora" (LIND, 1970, p. 249).

\section{IV}

Se Pessoa, todavia, chegou a realizar esta aproximação, dizendo-se mesmo "um poeta animado pela filosofia" (PESSOA apud LIND, 1970, p. 245), será preciso perceber as tensões que ela implica. Em primeiro lugar, será necessário chamar a atenção para as contradições inerentes ao pensamento do autor, as quais vão de encontro a certos princípios de uma filosofia como a de Platão. De início, basta lembrar que a tal "missão civilizadora" imaginada pelo poeta, remetendo à função que se atribui ao filósofo, em A república, será muitas vezes repudiada, na obra de Pessoa. Se o autor, em alguns momentos, fala efetivamente em trabalhar "para o progresso da civilização e o alargamento da consciência da humanidade" (PESSOA apud PERRONE-MOISÉS, 2001, p. 53), acreditando na "terrível e religiosa missão que todo homem de gênio recebe de Deus com o seu gênio" (PESSOA apud PERRONE-MOISÉS, 2001, p. 53), em outros será a postura cética, 
feita de dúvida e abdicação, senão de puro desdém aristocrata, o que se anuncia, como no Livro do desassossego: “... e um profundo e tediento desdém por todos quantos trabalham para a humanidade, por todos quantos se batem pela pátria e dão a sua vida para que a civilização continue..." (PESSOA, 1999, p. 70). Do mesmo modo contraditório, serão repudiadas, em muitas passagens de sua obra, a "análise psicológica", a "especulação metafísica" e a "emoção abstrata", mencionadas acima, bem como a própria ideia de coerência, seja no plano das ações do sujeito, ou da "conduta do indivíduo, e portanto da moral, em sentido estrito" (NUNES, 2010, p. 86), seja no do discurso, seja no dos fenômenos do mundo.

V

Com relação a esta posição diante dos fenômenos do mundo, e tendo em vista a proximidade entre as noções de coerência e harmonia, identidade, regularidade, ausência de variedade, de diversidade, de multiplicidade, vale a pena lembrar o poema em que o heterônimo Alberto Caeiro, criado para ser o mestre do próprio Pessoa, fala de uma suposta unidade da natureza, em 0 guardador de rebanhos:

Num dia excessivamente nítido,

$[\ldots]^{2}$

Entrevi, como uma estrada por entre as árvores,

O que talvez seja o Grande Segredo,

Aquele Grande Mistério de que os poetas falsos falam.

Vi que não há Natureza,

Que Natureza não existe,

Que há montes, vales, planícies,

Que há árvores, flores, ervas,

\footnotetext{
${ }^{2}$ Suprimi apenas dois versos do poema, o segundo e o terceiro da primeira estrofe. Inteira, ela é assim: "Num dia excessivamente nítido, / Dia em que dava a vontade de ter trabalhado muito / Para nele não trabalhar nada,/ Entrevi, como uma estrada por entre as árvores, / 0 que talvez seja o Grande Segredo, / Aquele Grande Mistério de que os poetas falsos falam." (PESSOA, 2003, p. 226-227).
} 
Que há rios e pedras,

Mas que não há um todo a que isso pertença,

Que um conjunto real e verdadeiro

É uma doença das nossas ideias.

A Natureza é partes sem um todo.

Isto é talvez o tal mistério de que falam.

Foi isto o que sem pensar nem parar,

Acertei que devia ser a verdade

Que todos andam a achar e que não acham,

E que só eu, porque a não fui achar, achei. (PESSOA, 2003,

p. 226-227).

\section{VI}

No poema, que repete características centrais da poética de Caeiro, incide-se deliberadamente sobre questão filosófica matricial, qual seja, a do conhecimento ou busca do princípio (arkhé) da Natureza (phýsis), atribuindo-se falsidade à crença em um tipo de mistério ("o Grande Segredo" ou "aquele Grande Mistério") que estaria para além das aparências do mundo concreto, onde se veem "montes, vales, planícies", "árvores, flores, ervas”, "rios e pedras", mas não se vê a natureza, simplesmente, como coisa mais geral, espécie de totalidade. Para Caeiro, com efeito, apenas em uma região abstrata, marcada pela invisibilidade, como em um mundo de ideias, poder-se-ia conceber a natureza como um universo ordenado, de maneira regular e integrada, como se fosse a unidade última de uma multiplicidade.

Recusa-se, assim, no poema, tanto o mistério dos místicos, sugeridos com a menção aos "poetas falsos", que falam em um "grande segredo", quanto a verdade dos filósofos. Ambas as figuras, poetas místicos e filósofos, são aproximadas em sua dimensão metafísica ou visionária, pois crentes em ideias como a de totalidade, conjunto abstrato, transcendente em relação às partes de que se forma, tomando como realidade o que não seria senão produto 
de uma fantasia. Ambos os tipos acreditariam poder recuperar o contato com uma forma de origem ou verdade superior, seja através da revelação, seja através da especulação. No primeiro caso, a verdade, ou um princípio, como a explicação do ser da natureza, seriam manifestados através de um modo de conhecimento excepcional, levando à essência das coisas. No segundo, seria através da razão, tornada o instrumento privilegiado, quando não exclusivo, de uma existência superior, que se poderia chegar ao verdadeiro conhecimento, no seio do qual, segundo uma filosofia como a de Platão, teriam lugar o imutável e o ser, em oposição ao mutável e ao devir.

Note-se, para além disso, ainda tendo em vista a questão da tensão entre coerência e incoerência a que o poema dá ensejo, a forma em si mesma contraditória que o discurso de Caeiro assume, paradoxal, primeiro, porque se trata de encenar a revelação em que se diz não acreditar ("Entrevi, como uma estrada por entre as árvores / O que talvez seja o Grande Segredo"), e, segundo, porque tal se dá através do próprio pensamento, que recusa o pensar. Negando-se a ideia de totalidade, de unidade, com referência à natureza, toca-se, ademais, em um ponto central da poética de Pessoa, o qual, com o jogo heteronímico, fruto, segundo ele próprio, de sua "tendência [...] para a despersonalização e para a simulação" (PESSOA apud LIND, 1970, p. 242), questiona, também no plano do sujeito, o "conjunto real e verdadeiro" que o poema associa a uma "doença das nossas ideias".

\section{VII}

No final do Livro II de A república, Sócrates, procurando levar o seu interlocutor a concluir o que ele deseja que conclua, perguntalhe o seguinte, remetendo às ideias de unidade e integridade que se vislumbrou acima: 
Mas as coisas melhores não são as menos sujeitas a metamorfoses e alterações por influência alheia? Por exemplo, o corpo mais saudável e mais forte não é o que menos se altera pela ação da comida, da bebida e do esforço, bem como qualquer planta sujeita ao calor do sol, ao vento ou a qualquer acidente dessa espécie? (PLATÃO, 2001, p. 94).

Ao falar de como são as melhores coisas, pensando, inclusive, na ideia de saúde, fica evidente que Sócrates considera a alteração algo pernicioso, sobretudo, quando se trata de uma alteração decorrente do que chama de "influência alheia". O trecho revela um valor que ele e Platão compartilham, qual seja, o valor daquilo que permanece, manifestando estabilidade e continuidade. Neste primeiro trecho, o exemplo é o do corpo, “coisa”, como diz Sócrates, que teria menos valor do que aquilo que vem em seguida, na continuação do diálogo, pois se fala da alma, que se acredita ter uma origem superior: "E quanto à alma, não será a mais corajosa e mais sensata a que é menos abalada e alternada por qualquer acidente externo?" (PLATÃO, 2001, p. 94). Novamente, então, aparecem os valores que a filosofia de Platão defende, agora, na associação entre o abalo e a alternância, por um lado, e a coragem e a sensatez, por outro. Sendo A república um diálogo que visa fornecer as bases ou um programa para a formação dos cidadãos, em particular, dos soldados ou guardiães de uma nova cidade, é natural que a corajem mereça destaque.

De todo modo, o que importa notar, neste passo, é que o programa pedagógico do filósofo, centrado em duas disciplinas fundamentais, a ginástica para o corpo e a música para a alma, teria como um dos seus valores primaciais a ideia de integridade, mesmo em um sentido simples, destes que se encontram em dicionários, como "estado ou característica daquilo que está inteiro, que não sofreu qualquer diminuição” (HOUAISS, 2007), que não sofreu, portanto, abalo ou alteração. 


\section{VIII}

É com a preocupação com a formação dos íntegros cidadãos da república ideal que Sócrates condena o que chama de "fábulas falsas" (PLATÃO, 2001, p. 87), ainda entre os livros II e III de A república. Falsas, neste caso, seriam aquelas tramas próprias dos poetas, os quais as contariam fugindo da verdade, mesmo os mais respeitados, como Hesíodo e Homero, até então referências maiores para a preservação da memória da comunidade. Os enganos aconteceriam, com muita frequência, afirma o personagem de Platão, sendo bastante específico, quando se trata de delinear "a maneira de ser de deuses e heróis" (PLATÃO, 2001, p. 88). Para Sócrates, com relação aos primeiros, seria verdade que "cada uma das divindades, sendo a mais bela e melhor que é possível, permanece sempre e de uma só maneira com a forma que lhe é própria" (PLATÃO, 2001, p. 95). Destarte, não se poderia, pois seria mentiroso, falso, pernicioso, dizer, como se vê na Odisseia, que os deuses assumem "aspectos variados" (HOMERO apud PLATÃO, 2001, p. 95). Ao final do Livro II, afirma-se que os deuses não podem mesmo ser representados como "feiticeiros que mudam de forma nem [como] seres que nos iludem com mentiras em palavras e atos" (PLATÃO, 2001, p. 98), como os representam os poetas, mentindo, eles também, e, assim, iludindo-nos.

\section{IX}

Já no Livro III da obra de Platão, Sócrates apresenta a imagem de um "homem honesto" (PLATÃo, 2001, p. 104), o qual se concebe como aquele que "se basta perfeitamente a si mesmo para viver feliz e que, diferentemente dos outros, precisa muito pouco de outrem" (PLATÃO, 2001, p. 104). Trata-se, muito simplesmente, de um homem autossuficiente, senhor de si, que não se abala, mais uma vez, pois que mantém a sua integridade, independentemente da 
"influência alheia". É tendo isto em vista que se critica, em seguida, a representação de Aquiles por Homero, porquanto o herói da Ilíada teria sido composto como "um espírito desordenado" (PLATÃo, 2001, p. 112), que alberga "em seu íntimo dois males contrários um ao outro" (PLATÃO, 2001, p. 112), quais sejam, "uma grosseira ambição" (PLATÃo, 2001, p. 112) e "um sobranceiro desprezo pelos deuses e pelos homens" (PLATÃO, 2001, p. 113). Aquiles, como um herói, não poderia ser representado de tal forma, segundo Platão, pois não se deve acreditar que ele seja contrário ao que se imagina que seja o herói, como ideia ou verdade a que se chega através do uso da razão, em acordo com o modelo de integridade e virtude, a ser seguido por aqueles que se quer educar.

Por fim, ainda no terceiro livro de $A$ república, na mesma altura em que passam a ser prescritas regras para o que se deve ou não imitar, já que as imitações podem se transformar "em hábito e natureza para o corpo, a voz e a inteligência" (PLATÃO, 2001, p. 120 ), acaba por ser proscrito da cidade o artista capaz de "tomar todas as formas e imitar todas as coisas" (PLATÃo, 2001, p. 124), o qual, ainda que "maravilhoso, encantador" (PLATÃO, 2001, p. 125), teria que dar lugar a uma figura mais austera "e menos aprazível, tendo em conta a sua utilidade" (PLATÃo, 2001, p. 125). Esta, para além de relacionada ao caráter didático que se imagina inerente à poesia, como parte da música, disciplina da alma, associa-se a uma divisão social do trabalho, das tarefas que caberia a cada homem desempenhar para exercer uma função junto à comunidade. Nas palavras de Sócrates, não deve existir, na imaginada república, "homem duplo nem múltiplo, uma vez que cada um executa uma só tarefa" (PLATÃO, 2001, p. 124).

\section{$\mathbf{X}$}

No Dicionário de Fernando Pessoa e do modernismo português, há um verbete dedicado a Platão, no qual se fala que o poeta "tomou 
muito cedo conhecimento" (DIX, 2010, p. 659) do filósofo, lendo, não apenas $A$ república, mas também outros diálogos, como o Protágoras e o Fédon. Entretanto, a relação estabelecida por Pessoa com o discípulo de Sócrates teria sido marcada mais pela rejeição do que pela assimilação. Em especial, manifestar-se-ia, na poesia de Alberto Caeiro, um "quase programa antiplatônico" (DIX, 2010, p. 660), repudiando-se o privilégio do mundo das ideias, com o seu pressuposto metafísico, em prol da experiência concreta do mundo sensível, sem mistério e sem transcendência, como se viu no poema mais acima transcrito. São também de Caeiro, aquele que disse que "pensar é estar doente dos olhos" (PESSOA, 2003, p. 205), os versos a seguir:

Sou um guardador de rebanhos.

0 rebanho é os meus pensamentos

E os meus pensamentos são todos sensações.

Penso com os olhos e com os ouvidos

E com as mãos e os pés

E com o nariz e a boca.

Pensar uma flor é vê-la e cheirá-la

E comer um fruto é saber-lhe o sentido.

$[\ldots]^{3}$

E me deito ao comprido na erva,

E fecho os olhos quentes,

Sinto todo o meu corpo deitado na realidade,

Sei a verdade e sou feliz. (PESSOA, 2003, p. 212-123).

\section{XI}

No texto em questão, não seria a virtude da integridade, decantada por Platão, o que estaria em jogo, mas ainda uma noção de verdade,

\footnotetext{
${ }^{3}$ Desta vez, suprimi os dois primeiros versos da última estrofe do poema, que transcrevo aqui, com a estrofe completa: "Por isso quando num dia de calor / Me sinto triste de gozá-lo tanto. / E me deito ao comprido da erva, / E fecho os olhos quentes, / Sinto todo o meu corpo deitado na realidade, / Sei a verdade e sou feliz." (PESSOA, 2003, p. 212-123).
} 
a qual também vai de encontro ao pensamento do fundador da Academia. Para o filósofo, como se sabe, a experiência sensível ocultaria a natureza das coisas, sendo "a visão intelectual das ideias" (NUNES, 2010, p. 94) o que fundamentaria "o conhecimento verdadeiro" (NUNES, 2010, p. 94), já que as ideias seriam imutáveis, mas aquilo que se dá à percepção sensível não. Aí estariam as bases, nas palavras de Benedito Nunes, mais uma vez, do "perfil metafísico" (NUNES, 2010, p. 105) do pensamento do autor, assentado na relação da verdade "com o que é eterno e imutável" (NUNES, 2010, p. 105) e na "dominância do suprassensível" (NUNES, 2010, p. 105).

O poema de Pessoa, entretanto, vai em sentido contrário ao que pensava o filósofo grego, manifestando o que se poderia chamar de um "credo sensacionista" (MARTINS, 2010, p. 881), próprio de Caeiro, o qual conceberia como fundamento de toda a verdade possível, não a razão dos filósofos, não a fantasia dos "poetas místicos", tipos metafísicos, mas a sensação, aquela que emana do corpo, dos cinco sentidos, dando forma e significado às coisas. Se existe critério para a determinação da verdade, ele estaria, neste caso, como para os epicuristas, na sensação.

\section{XII}

Pessoa, todavia, sabia não ser possível realizar, na prática, a lição do mestre, no que diria respeito tanto à sua experiência particular quanto à experiência do sujeito de seu tempo. Incapaz de estancar o impulso de interrogação sobre si e sobre o mundo, subordinando-o "à exigência de garantir a tranquilidade do espírito" (ABBAGNANO, 2000, p. 337), como fariam os epicuristas, o poeta se reconhece como um "raciocinador minucioso e analítico" (PESSOA apud FINAZZI-AGRÒ, 1987, p. 204) "um [obsessivo] analisador que busca, quanto em si cabe, descobrir a verdade" (PESSOA apud FINAZZIAGRÒ, 1987, p. 204). Neste passo, aproxima-se, então, novamente, do filósofo, ainda que de um filósofo que pensa para chegar à 
conclusão sobre o caráter vão do pensamento, ao menos, no que diz respeito à busca da verdade. Agora, é de ceticismo que se tinge o olhar do autor. Como se lê no Primeiro Fausto, acredita-se que "o erro é a condição da nossa vida, / a única certeza da existência" (PESSOA, 2003, p. 464). Restaria ao filósofo, assim, admitir-se apenas como um artista do pensamento, que teria, distanciandose de Platão, "tanto mais êxito quanto mais mentir a si mesmo e se compenetrar da verdade da mentira que criou" (PESSOA apud MARTINS, 2010, p. 881). Se a verdade idealmente se encontra na sensação, como quer Caeiro, tratar-se-ia, portanto, de uma das vias possíveis, a qual, no final das contas, mostra-se apenas como mais uma, embora, talvez, a mais desejável, já que aparece como a via daquele que se julga o mestre.

\section{XIII}

Se o problema, contudo, passa a ser encontrar a verdade da personalidade, tema central na poesia do autor, o cenário se torna ainda mais complexo, remetendo, mais uma vez, naturalmente, para o problema da integridade, agora visto sob a luz de uma tendência tipicamente moderna para a busca do que se poderia chamar de um eu autêntico, supostamente mais profundo e mais verdadeiro do que aquilo que se parece ser. A questão da integridade volta aqui à tona, sobretudo, porque, em meio à destacada percepção de que se pode travar apenas contato, no plano existencial, com "fragmentos do 'ser'” (FINAZZI-AGRÒ, 1987, p. 205), não se exclui, em Pessoa, como diz Ettore Finazzi-Agrò, a busca por um "Si orgânico e perdido" (FINAZZI-AGRÒ, 1987, p. 206) uma vontade de "regeneração do indivíduo" (FINAZZI-AGRÒ, 1987, p. 235). 0 poeta não deixa de buscar, com efeito, o que imagina poder ser um “'centro' egótico” (FINAZZI-AGRÒ, 1987, p. 210), o qual lhe permitiria, hipoteticamente, ser restituído a si próprio. Como se lê no Primeiro Fausto, trata-se de uma "pretensão a ser" (PESSOA, 
2003, p. 472). Ao mesmo tempo, todavia, experimenta-se, tanto no plano existencial quanto no intelectual, especialmente conjugados, um "incômodo de ter de ser idêntico a si mesmo" (FINAZZI-AGRÒ, 1987, p. 238), de onde se tornar a heteronímia, como processo por excelência de multiplicação, um caminho de aproximação de uma verdade, a "verdade egótica" (FINAZZI-AGRÒ, 1987, p. 205), que não poderia senão ter um caráter multívoco.

\section{XIV}

Com a metamorfose heteronímica, projeto que tem em vista a expansão de uma personalidade, Pessoa, por outro lado, aproximase do mito, retomado como prática que, sem se afastar de todo do pensamento racional, desloca-se para além de seu círculo restrito. Reconhecendo que, de todo modo, é apenas a fabulação mítica que poderia dar forma a uma espécie de "identidade original, 'natural' e integral” (FINAZZI-AGRÒ, 1987, p. 226), o poeta será, então, como imagina ser o filósofo, um artista do pensamento, fazendo um uso mitológico de sua "faculdade de abstração" (PESSOA, 1999, p. 106). Tendo-se em vista a experiência com "pedaços de uma verdade desmontada e dificilmente repetível na sua integridade" (FINAZZIAGRÒ, 1987, p. 206), mas se procurando "vencer a fragmentação do $e u$ " (FINAZZI-AGRÒ, 1987, p. 211), ainda que através da percepção raciocinada do caráter irrevogável da fragmentação, é que se institui aquilo que o próprio poeta chamou de "drama em gente" (PESSOA apud FINAZZI-AGRÒ, 1987, p. 211), objeto em que investe o seu poder de criação.

\section{XV}

Pessoa assume, assim, deliberada e conscientemente, o papel de um "criador de mitos" (PESSOA apud FINNAZI-AGRÒ, 1987, p. 228), 
atividade por meio da qual imagina poder se experimentar como um sujeito em expansão, vislumbrando, ainda que ao longe, em uma dimensão projetiva, alguma plenitude, ressonância fantástica de "uma vida total à qual é impossível renunciar" (FINAZZI-AGRÒ, 1987, p. 239). Se a verdade, a integridade, a totalidade, do mundo e do indivíduo, necessariamente subjetivadas, não são abarcáveis pela visão limitada que é dada a um único sujeito ter, restaria trilhar o caminho da multiplicação, tornando-se o vazio, a ausência, o ponto de partida para a fabricação, como diria Bernardo Soares, de um "mundo de imagens sonhadas" (PESSOA, 1999, p. 56), correspondentes a um "ser [que se quer] infinito" (PESSOA, 1999, p. 56). No plano da personalidade, considera-se, como se diz em "Tabacaria", que é por não ser nada, por não poder querer ser nada, que se pode, paradoxalmente, ter "todos os sonhos do mundo": "Não sou nada. / Nunca serei nada. / Não posso querer ser nada. / À parte isso, tenho em mim todos os sonhos do mundo" (PESSOA, 2003, p. 362). Seria nesta posição que o poeta se revestiria de um poder específico, o de um contraditório "poder ser" (FINAZZI-AGRÒ, 1987, p. 239). Conforme aponta ainda Finazzi-Agrò, lembrando algo que remete às condenações de Platão, em A república, aí estaria o "sentido da metamorfose heteronímica" (FINAZZI-AGRÒ, 1987, p. 239) de Pessoa, cujo movimento obrigaria o sujeito "a passar de uma identidade para outra, sempre estranho a si mesmo" (FINAZZIAGRÒ, 1987, p. 239), mas "sempre na pista de um Si orgânico e perdido" (FINAZZI-AGRÒ, 1987, p. 239), tornando-se a sua poesia "experimentação de existências alternativas na convicção [...] [de] que o ser se pode e deve resolver em existir, ou seja, em poder ser" (FINAZZI-AGRÒ, 1987, p. 239).

\section{XVI}

Se é pertinente afirmar que Pessoa procura "encontrar alternativas em relação ao domínio da razão" (FINAZZI-AGRÒ, 1987, 
p. 235), questionando a "hegemonia da racionalidade unificante" (FINAZZI-AGRÒ, 1987, p. 233), conforme as palavras de FinazziAgrò, é também necessário notar que tal não se dá sem que a tradição ou a história de que ele quer se afastar marque nele mesmo a sua presença, ocasionando tensões que não apresentam solução. Neste sentido é que se há de destacar a insistência na tentativa de recuperar "a si mesmo na sua plenitude" (FINAZZI-AGRÒ, 1987, p. 235), conforme o visto acima, pois que se trata da sobrevivência de uma ideia de integridade, cara a Platão, como se notou, no imaginário do poeta. De forma análoga, estaria longe de ser um mero acaso a sobrevivência de uma certa postura aristocrata do autor, remetendo à importância que se dá ao intelecto, à capacidade de pensar e de contemplar, a qual, em alguns momentos, associa-se à própria metafísica, como dimensão a que só homens superiores aspirariam.

Quando Álvaro de Campos, em “Tabacaria”, refere-se ao "Esteves sem metafísica" (PESSOA, 2003, p. 366), ele o faz marcando, precisamente, a sua diferença em relação a quem não é tocado pelo impulso especulativo. 0 poeta reconhece que pensar pode ser um mau, aproximando-se muito de Caeiro, neste ponto, quando afirma ter a "consciência de que a metafísica é uma consequência de estar mal disposto" (PESSOA, 2003, p. 366), mas indica, ao mesmo tempo, que se trata de um elemento distintivo de seres superiores. Em outro poema, também de Campos, o poeta deixa claro que acredita ser "a capacidade de pensar" (PESSOA, 2003, p. 402) o que sente, ou seja, a tendência a fazer dos próprios sentimentos objeto de reflexão, aquilo que o distinguiria "do homem vulgar" (PESSOA, 2003, p. 402). No Livro do desassossego, pululam frases de desprezo pela "humanidade vulgar" (PESSOA, 1999, p. 95), pelos "pobres diabos homens" (PESSOA, 1999, p. 102), cuja "horrorosa ignorância da inimportância do que são" (PESSOA, 1999, p. 96) não pode deixar de causar um enorme asco àquele que se considera o "único consciente" (PESSOA, 1999, p. 102), sujeito singular, justamente, por ter sido dotado de um intelecto privilegiado, o que equivaleria, 
em seu raciocínio, de fundo e vocabulário metafísicos, a ter uma alma.

\section{XVII}

Sendo um homem não vulgar, a tendência do poeta, no universo de Pessoa, seria o isolamento, o mesmo para o qual, significativamente, tenderia o filósofo, nos termos de Platão. De acordo com este último, com efeito, o filósofo, em seu caminho em direção ao aperfeiçoamento, deveria optar por "uma forma de vida autônoma, isolada e ascética” (NUNES, 2010, p. 91), bastante distinta da vida do homem comum. No projeto da República, de viés marcadamente aristocrático, os dirigentes seriam também filósofos, habilitados a comandar classes julgadas inferiores, como a dos artesãos, lavradores e comerciantes, vistos como simplesmente ignorantes ou apenas capazes de um "conhecimento de opinião" (NUNES, 2010, p. 94), limitado ao “domínio do sensível” (NUNES, 2010, p. 95). Os indivíduos das classes mais baixas, diferentemente dos filósofos, tomados como os novos mestres da verdade, terapeutas e censores, não seriam aptos a contemplar, a adotar uma "atitude constante e firme da alma, distanciada do imediato" (NUNES, 2010, p. 94), com a qual se veria, nas palavras de Benedito Nunes, "de longe e de cima as próprias ideias imutáveis que escapam à visão próxima e rasa da experiência sensível" (NUNES, 2010, p. 94).

\section{XVIII}

Em Pessoa, de modo expressivo, a contemplação também aparece como algo que merece destaque, lembrando uma tradição que não seria apenas de Platão, mas também de Aristóteles, para quem a vida contemplativa, em detrimento da vida voltada para a prática, seria a mais elevada (Cf. ABBAGNANO, 2000, p. 198-199). No Livro 
do desassossego, por exemplo, afastando o indivíduo dos negócios e sucessos do mundo, ela surge como "destino" (PESSOA, 1999, p. 45), em específico, agora, como uma "contemplação estética" (PESSOA, 1999, p. 45). Diferentemente da referida tradição, contudo, agora se trata de uma capacidade de reflexão voltada para a vida interior do sujeito, de que não se excluem as próprias sensações, "grandes países desconhecidos" (PESSOA, 1999, p. 46), cujos "modos e resultados" (PESSOA, 1999, p. 46) interessa ao poeta explorar e expressar. Não se poderia tratar, do mesmo modo, como em Platão, de uma "atitude constante e firme da alma", pois, nesta, o que vigora, para Pessoa, é um "desalinho triste" (PESSOA, 1999, p. 81), são "emoções confusas" (PESSOA, 1999, p. 81).

Para o poeta, de fato, o que se contempla são formas equívocas, incongruentes. Daí que a contemplação, como atividade daquela espécie de ser de exceção que é o poeta, também se revele como veneno, mais do que como remédio. É com a banalidade da vida comum, da vida sem contemplação, sem metafísica, que se associa a felicidade, não por acaso, também relacionada ao que Pessoa pensa serem as "artes inferiores e médias" (LIND, 1970, p. 248), que "proporcionam alegria" (LIND, 1970, p. 248), enquanto as "superiores" (LIND, 1970, p. 248), marcadas pela capacidade de abstração, seriam "profundamente tristes" (PESSOA apud LIND, 1970, p. 248).

\section{XIX}

Relacionado a esta importância que ambos os autores, Pessoa e Platão, dão à postura contemplativa, que os aproxima, ainda que com as nuances apontadas, há um último ponto, um desdobramento dos parágrafos acima, que valeria a pena destacar. 0 que acontece é que ambos os autores, de fato, fazem de uma dimensão suprassensível da existência, espaço localizado para além da realidade concreta, um objeto de fundo interesse. Naturalmente, como tentei demonstrar, 
em Pessoa, as posições, com relação a esta questão, não são estanques, comportando contradições, idas e vindas, movimentos de afirmação e de negação, ao contrário do que parece acontecer com Platão, em particular, em $A$ república, onde se identificaria o percurso em direção ao mundo das ideias como "um só trânsito, que vai do ilusório ao real, do aparente ao verdadeiro" (NUNES, 1999, p. 93).

Quando ressalta, entretanto, a insatisfação do poeta português com a realidade, vista como limitada, irreal, ilusória, seria também para um mundo outro que tenderia o sujeito, um universo de coisas impalpáveis, não visíveis com os olhos do corpo, mas apenas com os da alma, os quais seriam virtualmente capazes de estabelecer uma relação mais essencial com os objetos contemplados. Se esta relação, em Pessoa, dá-se, em especial, por força de uma faculdade como a imaginação, que seria própria da alma, de modo a se criar o que se vê, isto não escamoteia o fato de que se trata, também, como em Platão, de uma partida para outra dimensão. Nos primeiros versos de "Visão", soneto ortonímico, lê-se: "Há um país imenso mais real / do que a vida que o mundo mostra ter" (PESSOA, 2003, p. 106). Como diz Bernardo Soares, a realidade superior não seria a do mundo mesmo, em seu aspecto exterior, julgado "frívolo e trivial" (PESSOA, 1999, p. 71), mas a da alma, lugar de gestação dos sonhos, a que se atribui uma "soberana e pura grandeza" (PESSOA, 1999, p. 71).

\section{XX}

É mesmo para outro plano, então, que se direciona o poeta, assim como é para outro plano que se dirige Platão, quando concebe o caminho de ascensão do filósofo. Este, para Pessoa, como se viu, não deixaria de ser, também, um criador de mitos, e, portanto, necessariamente, um poeta-filósofo. Que Platão tenha sido, malgrado ele mesmo, um poeta-filósofo, inventor de uma forma 
dramática, é o que não se pode negar. Da outra parte, igualmente, não se pode negar que o procedimento de quem, indispondo-se com as limitações das ideias de integridade e coerência, metamorfoseou-se deliberadamente para ir ao encontro dos múltiplos fragmentos de seu potencial de ser, tenha algo a ensinar ainda hoje aos cidadãos, poetas, filósofos ou quem quer que seja interessado em ir para além da opinião não refletida, abrindo-se à música das musas, aquelas que, apesar dos pesares, sobrevivem.

\section{REFERÊNCIAS BIBLIOGRÁFICAS}

ABBAGNANO, N. Dicionário de filosofia. Tradução da 1aa edição brasileira coordenada e revista por Alfredo Bosi. Revisão da tradução e tradução dos novos textos por Ivone Castilho Benedetti. 4. ed. São Paulo: Martins Fontes, 2000.

DIX, S. Platão. In: MARTINS, F. C. (Coord.). Dicionário de Fernando Pessoa e do modernismo português. São Paulo: Leya, 2010. p. 659-660.

FINAZZI-AGRÒ, E. Utopia e verdade. In: . O álibi infinito: o projeto e a prática na poesia de Fernando Pessoa. [Lisboa]: Imprensa Nacional-Casa da Moeda, 1987. p. 201-284.

INTEGRIDADE. In: DICIONÁRIO eletrônico Houaiss da língua portuguesa. Rio de Janeiro: Objetiva, 2007. Versão monousuário 2.0. 1 CD Rom.

LIND, G. R. A hierarquia dos poetas e das artes. In: Teoria poética de Fernando Pessoa. Porto: Editorial Nova, 1970. p. 229-252. 
MARTINS, F. C. Verdade. In: (Coord.). Dicionário de Fernando Pessoa e do modernismo português. São Paulo: Leya, 2010. p. 880-881.

NUNES, B. Poesia e filosofia: uma transa; Introdução è República de Platão. In:____. Ensaios filosóficos. Organização e apresentação de Victor Sales Pinheiro. São Paulo: WMF Martins Fontes, 2010. p. 1-19; 75-117.

PERRONE-MOISÉS, L. O gênio desqualificado. In:

Fernando Pessoa: aquém do eu, além do outro. Nova ed. rev. e ampl. São Paulo: Martins Fontes, 2001. p. 45-92.

PESSOA, F. Livro do desassossego: composto por Bernardo Soares, ajudante de guarda-livros na cidade de Lisboa. Organização de Richard Zenith. São Paulo: Companhia das Letras, 1999.

. Obra poética. Organização, introdução e notas de Maria Aliete Galhoz. Rio de Janeiro: Nova Aguilar, 2003.

PLATÃo. A república. Tradução de Maria Helena da Rocha Pereira. Lisboa: Fundação Calouste Gulbenkian, 2001.

VILLELA-PETIT, M. da P. Platão e a poesia na República. Kriterion, Belo Horizonte, n. 107, jun. 2003, p. 51-71. 



\section{ÉDIPO HERMENEUTA - A DIMENSÃO POÉTICO-ONTOLÓGICA DA TRAGÉDIA}

\section{OEDIPOUS HERMENEUT - THE POETIC-ONTOLOGICAL DIMENSION OF THE TRAGEDY}

David FONTES

Katia Rose Oliveira de PINHO

Resumo: Este trabalho pretende dialogar com questões de Édipo, o personagem mitológico, no ensejo do teatro trágico de Sófocles. Em sua jornada reflexiva em busca de seu ser, sobretudo na peça Édipo Rei, Édipo investiga seu próprio caminho para a morte. Propomos refletir a morte como condição de possibilidade para a emergência de Édipo a partir de suas próprias ruínas. Assim, nosso pressuposto é que o des-encobrimento da verdade de Édipo culmine, ao final da peça, com a morte de uma de suas personas, de um dos eus da personagem. A questão da interpretação, portanto, é fundamental, e dela origina o título deste trabalho. Pois, Édipo é hermeneuta na medida em que interpreta o enigma que estrutura sua própria história mítica.

Palavras-chave: Teoria Literária. Édipo Rei. Interpretação. Poética. Tragédia.

Abstract: This work intends to dialogue with questions of Oedipus, the mythical character, brought about by Sophocles 
tragic drama. In his reflective journey in search of his being, especially in the play Oedipus Rex, Oedipus investigates its own path to death. We propose reflect the death as a condition of possibility for the emergence of Oedipus as from his own ruins. Thus, our assumption is that the uncovering Oedipus' truth culminate at the end of the play, with the death of one of his personas, one of the selves of character. The issue of the interpretation therefore is crucial, and it leads to the title of this work. Therefore Oedipus is a hermeneut in the extent that he interprets the enigma that structures his own mythical history.

Key-words: Literary Theory. Oedipus Rex. Interpretation. Poetics. Tragedy.

Este trabalho pretende dialogar com questões de Édipo, o personagem mitológico, no ensejo do teatro trágico de Sófocles. Em sua jornada reflexiva em busca de seu ser, sobretudo na peça Édipo Rei, Édipo investiga - ainda que sem saber - seu próprio caminho para a morte, de maneira tal que a morte se lhe impõe como princípio, caminho e destino - como método para a busca da verdade. Propomos refletir a morte como condição de possibilidade para a emergência de Édipo a partir de suas próprias ruínas. Assim, nosso pressuposto é que o des-encobrimento da verdade de Édipo culmine, ao final da peça, com a morte de uma de suas personas, de um dos eus da personagem. A questão da interpretação, portanto, é fundamental, e dela origina o título deste trabalho. Pois, Édipo é hermeneuta na medida em que interpreta o enigma que estrutura sua própria história mítica. Ele é hermeneuta na medida em que habita e canta sua moira, que vige sobre deuses e homens, desvelando-se a partir dela. Observa-se que Édipo, em seu percurso existencial, dialoga também com as mesmas questões, que serão em seguida abordadas.

A questão que move a procura de Édipo é "quem sou eu?". Também para nós, aqui, essa questão se apresenta como norteadora do diálogo. Quem é Édipo? Pouco nos auxiliaria uma coletânea de 
dados acerca da figura de Édipo, tampouco um mero detalhamento de sua narrativa trágica. Para que a questão alcance uma dimensão essencial, tal como para Édipo, essa pergunta deve ser entendida a partir de um questionar poético-ontológico. Sabemos que Édipo é um personagem mítico, mas o que isso significa? Afinal, o que é o mítico e o mito? A palavra mýthos tem sua origem etimológica no verbo mytheomai, que significa desocultar pela palavra. Palavra essa, organizada na forma de discurso sagrado, de palavra divina. Assim, dizemos que o mito é o próprio real a eclodir e vigorar desde a linguagem. Édipo é aquele que a partir do canto, do dizer poético se dá como gesto do real, como realidade e presença. Entender Édipo como uma personagem mítica, portanto, é reconhecê-lo como consumação do real e suas possibilidades.

Como interpretar a morte de Édipo na tragédia de Sófocles? A possibilidade mais ligeira é a de afirmar que, na conclusão da peça, Édipo, após perfurar os próprios olhos, é expulso de Tebas e permanece vivo e, logicamente, não morto. De fato, quanto a isso não há discussão. No entanto, creditar a morte como fim biológico de um ser vivo é já uma maneira de interpretar a morte. Essa interpretação permanece perfeitamente correta, mas longe de ser a única possível. A dificuldade de abordar a questão a partir de outro sentido além daquele mais explicitamente dado emerge de uma de-cisão histórica, a decisão pela metafísica, que instala o domínio da filosofia em toda a história do ocidente e que embota certas possibilidades de pensamento em favor de outras.

Esta de-cisão metafísica promoveu as transformações, as experiências e as interpretações de quase 25 séculos. A metafísica, por sua vez, corresponde a uma determinada maneira de ser real. Na metafísica, todo ente é observado e interrogado apenas enquanto ente. Disse-se "apenas" pois a possibilidade de observar e interrogar o ente enquanto ser é de todo esquecida, já que o ser (do ente) é esquecido. A partir do vigorar da metafísica é que foi suprimida a possibilidade de se relacionar com o real desde uma experiência poética. 
O exemplo clássico, talvez por isso mais desgastado, para compreender a questão da metafísica é o mito da caverna proposto por Platão no diálogo $A$ república. 0 mito mostra com clareza a separação do sensível e do inteligível, binômio em que se sustenta todo pensamento metafísico, e de que decorrem as distinções e as oposições entre certo e errado, morte e vida, claro e escuro, bem e mal, céu e inferno e tantas outras que se nos parecem hoje como totalmente indissociáveis.

No mito, o interior escuro da caverna é apartado do exterior luminoso e iluminado, em que este se projeta naquele criando uma representação do real a partir do jogo de luz e sombra, de maneira que os homens presos na caverna experimentam o real apenas e desde aquilo que esse jogo permite. Caberia a um desses homens, porém, sair da caverna e experimentar o mundo real exterior, educando os olhos ao mundo sensível, primeiro contemplando o céu noturno e, em seguida, o esplendor luminoso do sol. Esse homem estaria, assim, preparado a priori para ver e conhecer a realidade do real. Aqui se funda a possibilidade originária de ascensão da consciência metafísica. Ora, o cavernícola que torna a cabeça para a luz do fogo e para algo além da projeção de luz e sombra passa a estar condicionado a um ver apriorístico, o ver eidético, o ver da ideia. 0 ver idealizado do mundo. A experiência do sensível passa a ser anteriormente mediada pela presciência do inteligível. 0 ser é abstraído da coisa, restando somente a coisa pela coisa. Desse modo, passa a imperar a verdade a partir da aparência. Isso significa que a verdade das coisas não repousa na coisa e na sua maneira de se per-fazer tal como é, mas na capacidade de o homem a conhecer a partir do dado aparente, daquilo que lhe é permitido abstrair e formular como ideia. Assim, se por um momento vemos um objeto qualquer, um sapato, a visão eidética vê não um sapato sensivelmente experimentado, mas a ideia do sapato, que já existe em nós a priori. A visão aparente do sapato é supra(meta)-sensível(phýsis) - metafísica, metaphýsis. Pensar a coisa desde a ideia da coisa, do supra-sensível, é o que distingue o 
pensamento metafísico (HEIDEGGER, 1991). Os gregos eram muito visuais. Eles aprendiam o mundo primeiramente através dos olhos. Daí, a terrível condição a que Édipo se impõe ao fim da tragédia, antes de ser expulso do Tebas. O castigo que Édipo escolhe para infligir a si mesmo aponta a relevância da experiência do ver tanto em sua condição particular, como aquele capaz de enxergar tudo, quanto como homem grego. 0 ver, para os gregos, e também para Sófocles, se dava de uma maneira diferente do ver eidético impresso pela metafísica. Para Sófocles, tanto o ver como a coisa vista não se distinguiam uma da outra, de maneira que uma depende da outra para que aconteça, para que se perfaçamtão como são. Assim, uma perspectiva não é algo em si prévio que será oportunamente adotado pelo ver, isto é, por um sujeito que se apropria. 0 ver e o visto se dão mutuamente como concretização do real.

Ao se estranhar a questão acerca de uma possível morte de Édipo, ao final da tragédia de Sófocles, já se assume um determinado sentido à morte. Nesse sentido lógico, Édipo não pode ter morrido, já que ao final da peça permanece ainda vivo. Algo não pode estar morto e vivo. Essa maneira de interpretar a morte é fruto das possibilidades ofertadas pela consciência metafísica, no entanto não poderia ser mais distante da noção grega trágica de mundo a que a obra pertence. Não se pretende, é claro, argumentar a favor de um Édipo morto-andante, um morto-vivo. De maneira que não se deseja falar aqui a respeito dos eventos de que se morre. 0 que se pretende é deitar de lado a noção dos binômios autoexcludentes e questionar a partir de um pensamento mais antigo do que seja a morte, mas que se nos faz presente a cada vez que lemos e relemos qualquer tragédia grega. Queremos questionar a essência da morte. 0 exercício de questionar a essência dos seres nos aproxima da noção grega de co-relacionar-se com o mundo e, dessa maneira, nos dá possibilidade de interpretar a tragédia de modo mais originário.

Por outro lado, não se pode furtar ao problema que é indagar as possibilidades de realizar tal feito. Como é possível efetivamente questionar o real e as dádivas do real de uma maneira já há tanto 
esquecida, de uma maneira grega? De fato, quanto distamos da possibilidade de poder, a rigor, lançar uma questão acerca da essência de algo? Um discurso que pretenda dizer a essência da morte - ou, no limite, a essência do que quer que seja - será sempre um discurso falso. Nessa afirmação, porém, já acena uma con-vivência dinâmica, um habitar o próprio inefável. Seja como for, é preciso admitir que em cada pergunta-questão lançada já se lhe encontra, inerente, uma resposta que, por sua vez, já novamente torna à questão que a origina e sempre origina. 0 exercício, talvez, seja pôr em prática o mesmo método - que nada mais é do que se dispor ao caminho - a que por sua vez Édipo se lançou: o exercício de questionar(-se).

\section{I}

Quem é Édipo? A partir da interpretação literária que propomos, revigoramos a mesma pergunta que desvelou o destino terrível da personagem trágica, isto é, "quem sou eu?". A pergunta, no entanto, é dada desde outro matiz, ou melhor, aparece velada, posto que aquele a quem se procura, conforme o conhecer apriorístico de Édipo, é o assassino de Laio, que, por vagar impune entre os bons cidadãos, faz cair uma peste sobre a cidade de Tebas, onde reina Édipo.

Édipo, desde o começo da peça, é aquele para quem o conhecer se lhe impõe como ordem. Nesse caso, o conhecer de Édipo e sua relação com ele não se dão meramente como coisas fortuitas, mas operam sempre em favor da pólis. É visível desde o evento anterior do enigma da Esfinge, que Édipo resolve, que seu conhecimento é em favor do coletivo, tanto que lhe é dada, por justiça, a cidade para que fosse governada. 0 conhecer de Édipo se mostra mais como um estar informado acerca de algo e de suas relações, de maneira que esse conhecimento lhe permita dominar esse mesmo algo, mas o que lhe falta é o conhecimento que se volte para o que as coisas são em 
seu fundamento, em sua essência. Esse saber essencial, que escapa a Édipo, é que permite não dominar as coisas, mas ser tocado por elas. Heidegger (1991) relembra o poema de Hölderlin "Num azul amável floresce...", no qual o poeta alemão reflete acerca da figura de Édipo, "O Rei Édipo talvez tenha um olho demais". Esse olho a mais de Édipo é aquele que lhe configura o caráter investigativo num fundamento metafísico que sempre busca a identidade na identidade e nunca como igualdade, que é incapaz de encontrar a igualdade no próprio seio da diferença. Mesmo na estrutura formal da linguagem, a resposta de Édipo à "ríspida cantora" já lhe apontava o caminho em que estava inserido e a forma com que se dava o seu conhecer. A Esfinge pergunta qual ser possui dois, três e quatro pés - dípous, trípous, tetrápous, ao que Édipo lhe responde: "homem" - oi-dipus. Esse saber, no entanto, é, em seu particular, indicativo do saber geral de Édipo, que sem deixar de ser um saber efetivo é, ainda assim, apenas aparente. Pois, mesmo que dissolvido o enigma proposto pela Esfinge, permanece inalcançada a questão primeva “que é o homem?", que circunscreve e é a mesma questão de Édipo: "quem sou eu?". Assim, já desde o começo da tragédia sofocliana, antes mesmo que Tirésias retorne da visita ao oráculo de Delfos com a instrução divina para pôr fim à peste, o ímpeto de Édipo é violento, pois quer a todo custo desvelar aquilo que está oculto, e responde ao chamado do Sacerdote que fala pela população, em razão da peste instalada na cidade (v. 71-2):

\author{
ÉDIPO: \\ (...) a paz como devolvo \\ A Tebas, com palavras ou com atos?
}

Com efeito, a investigação de Édipo lança-o sempre em direção ao conhecer. Édipo é o homem de maior saber e justamente isso lhe concede o reinado em Tebas. O saber de Édipo, no entanto, é sempre mais do que um simples conhecer, pois as questões todas que embalam seu percurso não se mostram como um conhecer ou não conhecer algo, mas como um conhecer ou não conhecer a si, 
e isso é decisivo para seu destino. Portanto, se por um lado Édipo é aquele capaz de resolver todos os enigmas e elaborar todos os engenhos, ele é tão incapaz, quanto qualquer homem, de responder à questão "o que é o homem?". Isso torna o saber de Édipo um falso saber, na medida em que ele tanto sabe quanto não-sabe. Tomemos como exemplo a visita de Édipo ao santuário délfico, quando ainda morador de Corinto. Naquela época, ele recebeu a profecia antes dada a Laio, isto é, de que cometeria parricídio e incesto. 0 saber que Édipo tem de si, então, é falso, pois ele se presume como filho de Políbio e Mérope, no entanto, é, no mesmo grau, verdadeiro, pois já ali lhe é dada a saber a moira a que pertence, a que está pertencido. Édipo sempre soube e não soube, isto é, sabia conforme desconhecia, e vice-versa. Ora, a tensão entre esse saber e nãosaber é que o levará a abandonar Corinto e, justamente nessa fuga, o fará cumprir seu destino trágico.

A resolução do enigma da Esfinge é um evento anterior àqueles dados na peça de Sófocles, quer dizer, quando a peça se inicia, Édipo há muito já visitou o templo délfico, abandonou Corinto e, sobretudo, já matou o pai e desposou a mãe. Não se pode, então, buscar uma interpretação, pelo menos uma que se queira mais próxima da verdade poética trágica, se consideramos que a peça de Sófocles desvela o destino de Édipo a partir de uma representação lógica de eventos concatenados. No entanto, é justamente essa interpretação que, desde $A$ Poética de Aristóteles, tornou-se normativa na tradição literária ocidental (SOUZA, 2010). A interpretação proposta por Aristóteles para a tragédia de Sófocles, assim como para qualquer outra tragédia grega e para toda interpretação literária banhada pelo postulado aristotélico, peca por esquecer ou ignorar o sentido trágico nessas obras gregas.

O que se entende hoje por trágico em nada diz respeito ao trágico 
poematizado por Ésquilo, Sófocles e Eurípedes. A palavra "trágico", ou "tragédia", não é alheia ao uso do vulgo, isto é, não é um termo que surge tão-somente no ensejo dos altos estudos catedráticos deste ou daquele tema. Se perguntássemos a quem quer que fosse, o que ouviríamos, com mais ou menos variações, é que trágico é aquilo que traz mortes ou tremendas desventuras, algo calamitoso, sinistro, funesto. Se um avião cai causando a morte de centenas de pessoas não será raro que se diga do incidente como sendo trágico, uma tragédia em si. Não se discute o nível de correção do uso da palavra, mas, assim como a dificuldade de observar, no contexto antes referido, a morte em Édipo, a utilização da palavra "trágico" da forma como se disse também aponta para uma maneira de lidar e interpretar a palavra. Essa maneira não era a maneira entendida por Sófocles, nem poderia ser.

Cabe, então, questionar o sentido do trágico na consciência grega antiga. Sim, pois se referir a uma noção de trágico que leve em consideração apenas o contexto "grego" não nos aproxima do âmbito do questionar a que desejamos. A paideia grega de Sócrates, Platão e a Grécia helênica de Aristóteles é bastante distinta daquela em que outrora foram encenadas as peças de Sófocles. A primeira, como se disse, consolidou todo o pensamento e a forma de pensar da sociedade ocidental, sombreando toda organização dessa mesma sociedade e chegando até nós, hoje, como numa avalanche; a outra, diferentemente, compreende um mundo que, hoje, talvez, não tenha mais espaço. Nesse mundo, a essência do homem era trágica. Já que há quase 25 séculos a história da humanidade é a história da impertinência de ser e pensar, que grassa como uma tosse crônica, talvez, pelo menos à guisa de reativar essa possibilidade, mais nos interesse cuidar em atenção e defrontar esse homem outrora trágico.

Antes da instituição da dicotomia metafísica e da filosofia a partir de Platão, a Grécia já se havia permitido outras maneiras de dialogar com o real. Referimo-nos, sobretudo, aos pensadores gregos antigos Anaximandro, Heráclito e Parmênides. Muito 
embora o cânone literário estabeleça uma relação crítico-teórica das tragédias com a Poética de Aristóteles, é com esses pensadores que as tragédias dialogam mais essencialmente. A filosofia comumente se refere a esses três pensadores como "pré-socráticos". Mas nosso percurso não deve passar incólume por isso que parece apenas um posicionamento nomenclatório dado a partir de um fato histórico, mas que denuncia a de-cisão pelo domínio dicotômico. 0 uso do prefixo "pré-" assegura a posição privilegiada da metafísica, que tem seu germe em Sócrates, como o parâmetro a que se deve seguir, de maneira que a escolha pelo prefixo não sugere uma mera indicação cronológica, mas é, sobretudo, axiomática. É o axioma da ascensão da filosofia e do declínio do pensamento (LEÃO, 1980). A opção por um nome desvela a fragilidade de dois mil e quatrocentos anos de racionalismo. Pensar o pensamento dos primeiros pensadores não significa uma tentativa de reproduzir com fidelidade aquilo que porventura tenha passado no cérebro desses homens nem, tampouco, nos forçar a pensar como eles, o que é tão falso e impossível quanto inútil e desnecessário. Pensar desde o pensamento dos primeiros pensadores significa experienciar a miopia do pensamento em que hoje nos debatemos.

"Existe somente a tragédia grega e nenhuma outra além desta. Somente a essência do ser, como experimentado pelos gregos, tem essa originariedade, que faz o trágico se tornar aqui uma necessidade" (HEIDEGGER, 2008). 0 pensamento trágico compreende o real em seu fundamento dionisíaco, isto é, no qual o deus grego se dá como a reunião acolhedora das diferenças na unidade e permite emergir todos os entes que se resguardam no acolhimento da vida e da morte. Tanto para os tragediólogos quanto para os primeiros pensadores gregos, trágico era o ser da própria realidade, trágica era a totalidade do real. Um pensamento recíproco para o que ao mesmo tempo se dá em consonância e dissonância, isso é pensar trágico. Que o dia e a noite circulamse, submetidos ao tempo, que os homens vivam como seres prometidos para a morte e que na morte vige, indistinguível, a 
vida, isso é trágico. Na execução do inexequível está o trágico. É dessa substância, que regia a tessitura do mundo, que se origina o pensamento presente tanto nos fragmentos dos pensadores quanto nas tragédias dos poetas gregos que hoje nos chegaram. Assim, a tragédia surge dessa "tensão harmônica dos contrários em luta em todos os aspectos da realidade cósmica” (SOUZA, 2010). Heráclito afirmava a identidade na diferença, a unidade na multiplicidade, a permanência na mudança, do repouso no movimento.

O contrário em tensão é convergente; da divergência dos contrários, a mais bela harmonia. (Frag. 8)

(...) harmonia de movimentos contrários, como do arco e da lira. (Frag. 51)

Aquilo que se mostra ao passo que se encobre, aquilo que, como um vaga-lume, se acende ao passo que escurece. Não é possível aproximar-se da fala do pensador se estamos arraigados no conceitual que a filosofia demanda e em que se estrutura. 0 dito seria de todo "sem sentido", "sem lógica". Justamente, o que lhe falta é essa lógica tão prezada e necessária ao raciocínio adequado do homem ocidental, mas é nessa ausência que se encontra o precioso e raro. E é nesse instante que se torna propício vislumbrar aquilo que projetamos como trilha de um caminho.

Quem é Édipo? A questão agora acena de outra perspectiva, pois compreender o mundo em que Édipo se insere deixa ver as possibilidades a que Édipo estava lançado. Édipo é uma personagem trágica, sabê-lo assim já nos diz muito, talvez mesmo tudo de que necessitamos. Trágico não compreendido por seu destino terrível, mas sua essência radicalmente paradoxal, pois habita em si a violenta tensão entre o poder de realização intelectual e a impotência calcada na ignorância, entre voluntarismo e fragilidade.

Vejamos: Édipo foi criado por Políbio e Mérope e era filho biológico de Laio e Jocasta, aquele a quem assassinou e esta a quem desposou. Foi criado em Corinto, de onde fugiu, chegando a Tebas, onde reinou e nasceu - este, fato que toda vida ignorou. Todas essas 
são proposições acertadas acerca de Édipo, mas em que medida dizem o que foi Édipo? Isto é, como nos auxiliam essas informações, dadas assim? Talvez mais do que as respostas, as questões possam nos dar um rumo mais frutífero. Qual era a origem e o habitar de Édipo? É preciso, no entanto, que se entenda essa origem e esse habitar a que se questiona desde uma dinâmica poético-ontológica. Assim, não nos interessa saber a origem de Édipo como seu inaugurar cronológico para uma sequência linear; do mesmo modo, não nos interessa saber o habitar de Édipo como descrição de suas instalações residenciais neste ou naquele período. Origem e habitar são tratados aqui de modo distinto. Queremos entender a origem de Édipo como sua arché, como aquilo a que Édipo, em resposta à sua essência, precise sempre retornar para que se constitua em seu páthos como aquilo que é, como vigorar de uma cadência. As reflexões do coro acerca dos sentimentos e aflições das personagens em cena já apontam também para a origem de Édipo, a mesma que faz cumprir sua moira:

CORO:

(...)

um desgraçado

que traz no pé a desgraça! (Ver. 478-9)

A chaga que Édipo traz no pé acena também desde o dizer de seu próprio nome. Édipo - Oidipous - devira oideo ("inchar") e pous ("pés"). Édipo é o "de pés inchados", referência ao defeito físico que o herói carrega desde os primeiros dias de vida provocado pelo pai, Laio, antes de entregar o filho para que fosse abandonado em monte ermo. Aquilo que Édipo "traz", traz como originário de si mesmo, aquilo que o constitui como presença seja em Corinto ou Tebas, ou em que tempo for, já lhe fora assegurado desde a origem, garantindo a segurança do ser, verdadeiro e essencial, mesmo que num invólucro de uma aparência que não corresponda à verdade.

Igualmente, entender o habitar em Édipo é lançar luz sobre 
aquilo que em Édipo vem resguardado na cadência que sua arché permite. Daí que não se possa distinguir de uma a outra questão, já que perguntar pela origem já é sempre remeter a um habitar. De que modo, então, podemos perguntar sobre esse habitar e originar de Édipo, visto que seu próprio verdadeiro ser esteve sempre oculto? 0 comportamento de Édipo, encolerizado quando do confronto com Tirésias, é justificado naquilo que ele desconhecia em sua origem e em seu habitar, mas que para Tirésias era sabido (Ver. 337-8):

\author{
TIRÉSIAS: \\ (...) \\ O meu comportamento recriminas \\ Por ignorares o que habita em ti
}

Tirésias não se refere ao habitar de Édipo como algo que lhe é exterior, isto é, não se refere ao habitar como habitar em Tebas ou Corinto ou algures. Tirésias refere-se ao que em Édipo habita. 0 que em Édipo é aquilo que essencialmente corresponde a Édipo; ou melhor, o que habita em Édipo é o próprio Édipo. Mas não se pode dizer que Édipo tinha de si apenas uma consciência falsa, posto que ele não vive em ilusão, de maneira que ele jamais poderia ter de si uma noção falsa. Porém, o que ele tinha de si era uma falsa verdade ou uma verdade aparente. Essa verdade é posta em dúvida por Tirésias, que instiga em Édipo a obsessão por não mais revelar o assassino de Laio, mas sua própria história e seu próprio ser ora postos em dúvida, mas que, em última instância, correspondem à mesma pessoa. (Ver. 414-15)

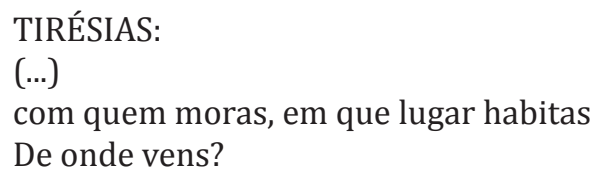

Essa obsessão de Édipo é que estabelece uma tensão entre a verdade aparente - des-encoberta - e a verdade essencial encoberta. Nessa tensão reside aquilo que consideramos como ponto fundamental para entender a jornada de Édipo - alétheia. 


\title{
III
}

Alétheia, no grego, significa des-encobrimento, e aponta para uma das formas como eles, os gregos, se relacionavam com a verdade. 0 conceito em nada se parece com a forma como nós, homens ocidentais, lidamos com a verdade. Nossa verdade advémde enunciações provenientes dos dados da "realidade". Assim, por exemplo, se tocamos em uma superfície como uma mesa de mármore, dizemos, "esta superfície é rígida". E isso é verdade. Tão verdade quanto se disséssemos, “esta superfície não é moleável”. Essa forma de obtenção da verdade, por meio de uma enunciação que se pretenda correta, é fruto da subjetividade que adequa e adjetiva os entes em conforme sua necessidade - o homem como sujeito sujeitador da realidade -, e não corresponde à verdade obtida desde um des-encobrir. A verdade enquanto des-encobrimento é o real se fazendo realidade como presença. Se, por um lado, a verdade dada a partir da enunciação emerge de uma fala, a verdade dada a partir da alétheia emerge de uma ausculta silenciosa. Na dimensão trágica da peça, essa verdade é assegurada e se faz presente desde o aceno divino re-apresentado na figura de Tirésias cantada pelo coro (Ver. 297 e seg.)

\author{
CORO: \\ [...] Aqui já trazem \\ O divino profeta. Nelo só \\ Se infunde o Desocultamento: Alétheia.
}

E na fala do próprio Tirésias:

TIRÉSIAS:

[...] pois me nutre o vero, a própria Alétheia.

A verdade de Édipo se dá desde um des-encobrimento. 0 começo e o fim do Édipo rei formam dois polos opostos, dois eus de uma mesma persona, de uma mesma personagem. Esses dois eus co-pertencem, todavia, a uma mesma unidade, conservando igual 
intensidade e amplitude, sendo anversos proporcionais, simétricos. 0 eu inicial é aquele calcado numa verdade falsa, posto que apenas aparente, o segundo eu representa a ruína - a morte - do primeiro, onde se gera a verdade essencial do ser, isto é, o ser de Édipo. Daí que a morte do eu falso permita a emergência do eu verdadeiro. Toda a peça trata da tensão entre o recolhimento para o encobrimento de um eu até a exposição e des-encobrimento do outro eu. Essa tensão gerada se dá quando a estrutura de aparência a que Édipo se viu sempre submetido é posta em questão, e isso vai ocasionar que a revelação, o des-encobrimento da verdade se dê através do próprio esforço investigativo de Édipo.

A ideia da verdade - não se trata aqui de falar de realidade, já que, no início, Édipo não vive em ilusão, mas na falsidade objetiva e na aparência -; como dito, é, na estrutura da aparência, o resultado de dois eventos: o primeiro é marginal, o segundo central. 0 primeiro nasce da seguinte pergunta: o que é isso que se oculta de mim e que se me impõe como tarefa a ser esclarecida? O segundo parte da seguinte: o que sou eu e qual meu próprio ser? (REINHARDT, 2007, p. 121)

Essas duas questões se relacionam com Édipo de maneira diferente. A primeira surge como uma tarefa política, aquela a que Édipo se submete em favor da pólis, de maneira que a questão se veja tomada pela ação subjetiva da investigação de Édipo, estabelecendo uma relação de sujeito e objeto; a segunda, para a qual ele gradualmente se encaminha, se mostra numa relação que não permite ser objetivada, já que a questão, ela mesma, não se distingue do próprio Édipo. A relação de conformidade, sujeito e objeto, a que Édipo esteve sempre habituado não se mostra possível desta vez, já que o próprio ser que motiva Édipo à questão é, na mesma medida, motivado por ela, um governado pela outra. Os processos interiores da mente de Édipo, seu poder de raciocínio e investigação se mostram, agora, incapazes de concordar de forma verdadeira com os fatos exteriores. 
O Édipo Rei, contrário ao que a interpretação aristotélica sugere, não é, de modo algum, a tragédia do destino humano, apesar de ter sido por muito tempo considerada como modelo para esse tipo de obra. Na interpretação de Aristóteles, o "destino" é subentendido no binômio metafísico destino x liberdade, sendo que, na peça, a liberdade ética do ser humano é suprimida pelo destino imposto pela vontade divina, o que nos leva a entender Édipo como o resultado de um joguete de forças divinas. Édipo Rei é, como sugere Reinhardt (2007), a tragédia da aparência (Schein) humana, que por sua vez não se confunde com o falso, mas se apresenta como um modo de ser em cujo panorama o homem vive a escassez da dádiva poética. 0 coro, que em instante algum canta o destino, canta e questiona a eminente aparência de Édipo e dos homens (Ver. 1188 e segs.)

\author{
CORO: \\ Estirpe humana, \\ o cômputo do teu viver é nulo. \\ Alguém já recebeu do demo um bem \\ não limitado a aparecer \\ e a declinar \\ depois de aparecer?
}

Se Édipo Rei é a tragédia da aparência humana, não há espaço para uma interpretação tal como a que propôs Aristóteles. Para se pensar a questão do destino na tragédia de Édipo é necessário entender esse mesmo destino desde um percurso trágico, tal como a natureza do drama ático. Não corresponde a essa natureza, portanto, uma interpretação do destino como um impedimento ao livre agir das disposições intelectuais humanas. 0 destino do homem, na tragédia de Sófocles, está fundado na alétheia, e se dá enquanto abertura desveladora de si para o ser. 0 destino do homem se dá enquanto presença na terra como ser prometido para a morte, e toda presença, enquanto desvelamento, vigora na tensão do diálogo essencializado enquanto verdade e linguagem. A 
alétheia, que dis-põe o ser para a dinâmica de declinar e aparecer, determina a irrupção do próprio ser na emergência de sua essência, que, inevitavelmente, sempre se mostra. Por essa razão, os deuses gregos, como também os homens, nada podem diante do destino ou contra ele. A moira vige anteriormente e sobre deuses e homens. $\mathrm{Na}$ peça, as referências à moira estão sempre entre-tecidas na noção de Sófocles da experiência trágico-poética. Assim, a moira aparece quando Édipo se põe a amaldiçoar o assassino que busca, o que é uma fala pública na medida em que é pessoal.

\author{
ÉDIPO: \\ Ao inferno - assassino! - esteja oculto \\ sozinho ou com o bando de comparsas. \\ Na miséria, sem Moira, acabe o mísero!
}

A Tirésias, pela dádiva divida, é dado ver a verdade em seu desvelamento. Assim, ainda que Édipo tente se valer da cegueira do profeta e acuse-o de ser, por isso, incapaz de atingi-lo com suas acusações, Tirésias vê a senda de Édipo. Ironicamente, naquele instante, Édipo é aquele que enxerga, mas não vê (ver. 376-7).

\author{
ÉDIPO: \\ Te nutre Nýks - noite. És incapaz \\ de fazer mal a quem com luz convive. \\ TIRÉSIAS: \\ Não cabe à minha Moira sobre ti \\ cair. Do fato Apolo cuida. E basta.
}

A referência de Tirésias a Apolo não significa que parte desse deus a decisão do destino de Édipo, sua queda não é justificada numa decisão dos olímpicos, eles apenas a predisseram. Assim, como aponta Reinhardt (2007), não trata-se, de um jogo de gato e rato, no qual os deuses impõem um destino que se põe à espreita de uma vítima sem que esta suspeite de nada. Dizer que os deuses são responsáveis, como Édipo diz (ver. 1329-30), 
ÉDIPO:

Apolo o fez, amigos, Apolo

Me assina a sina má: pena apenas.

não significa compreender os deuses como senhores do destino de Édipo - pois sequer são responsáveis pelos seus próprios -, mas que eles, no máximo, permitem a dinâmica da alétheia sobre a vida, para que ela seja o que vem a ser. 0 elemento, o destino não é acaso misterioso ou designo de divino, mas o próprio fazer-se da vida enquanto vida. Édipo não é, portanto, aquele a quem sua liberdade se veja impedida, mas aquele que, vivendo uma aparência, acredita contornar o próprio destino. Ele sempre agiu desde sua própria livre vontade. Tanto é assim, que ele, mesmo naufragado em ruína, não admite que suas ações, por mais brutais, possam ser interpretadas como demandas alheias à sua própria vontade. (ver. 1331-32)

\footnotetext{
ÉDIPO:

Ninguém golpeou-me, além das minhas mãos.
}

De fato, a desgraça e a dor que Édipo aflige a si mesmo são consoantes às mesmas maldições lançadas por ele no início da peça, quando o assassino ainda estava oculto. A partir do momento em que Édipo é capaz de vislumbrar com clareza a sua jornada, percebendo-se como assassino e incestuoso, ele reconhece a sua moira. E se antes havia acreditado transgredi-la, finalmente se dá conta de que jamais esteve além ou aquém das pre-visões dos oráculos divinos (ver. 1458).

ÉDIPO:

Que a Moira me encaminhe ao meu destino!

IV

Édipo rei é a tragédia da aparência humana e do declínio da 
aparência (Schein) (encobrimento) até que se dê a re-velação (Unverborgenheit) do ser. Justamente por isso não se deve ver em Édipo apenas a ruína, o declínio. 0 declínio acena como a única condição possível para a emergência de uma ascensão, ainda que para Édipo o que se revela dessa ascensão seja terrível ao ponto de ser suportada apenas perfurando-se os olhos, os mesmos olhos que lhe deram o conhecimento falível do mundo, fazendo cair sobre si o império da noite. Por outro lado, não se deve entender a tragédia de Édipo como mera disposição dos eventos que ascendem, o que significaria novamente entendê-la com a tragédia do destino humano, desvelado na peça desde o encadeamento dos fatos. Entender a tragédia de Édipo e a própria noção grega do trágico é perceber a co-existência do declínio e da ascensão, que permitem o ser de Édipo apenas na medida em que existam nesse e desde esse conflito. Compreender esse conflito é apreender o próprio horizonte da noção da trágica grega.

De certo modo, Édipo depois de cegar-se passa a ter a mesma noção des-encoberta do real que Tirésias, pelo menos no que tange a si mesmo. 0 próprio Apolo que Édipo acusa de ter-lhe arruinado é o mesmo que predisse e permite a doação e a exposição do ser de Édipo em toda sua plenitude. Mas não se trata meramente de considerar o Édipo cego com o expurgado, aquele a quem a revelação, caindo-lhe sobre, instantaneamente lhe faz melhor ou livre de imperfeições. Essa interpretação aponta um reflexão deficiente acerca da aparência do falso, que decorre num engano. A aparência não faz com que Édipo apenas se mostre, como ente, naquilo que ele não é, mas, também, encobre a si mesma, como aparência, ao passo que se mostra como ser. Como aponta Heidegger (1991), a aparência somente porque engana a si mesma é que pode enganar ao homem. Essa ilusão, contudo, é que possibilita a própria mobilidade do homem na tensão de ser e não-ser, da mesma maneira que mobilizou Édipo a declinar de si e para si surgindo, cônscio de sua origem, como Édipo. Disso é que nos fala os versos finais da peça, na última reflexão do coro (ver. 1528-30). 


\section{CORO:}

Atento ao dia final, homem nenhum

afirme: eu sou feliz!, até transpor

- sem nunca ter sofrido - o umbral da morte.

Aqui, o que se lê é a observação culminante da moira pertencente a Édipo. 0 coro refere-se aos homens não como seres fadados a um destino elaborado além de suas forças, mas ao homem como aquele que vaga na tensão do aparecer e do resguardar-se. Assim, afirmar “eu sou feliz!", tal como era a condição do rei tebano no início da peça, agraciado pelos homens e pelos deuses, é erigir as próprias paredes a ilusão em que se pretende habitar. “eu sou feliz!”, na tragédia de Édipo, é justamente a fala daquele que se apresenta numa ilusão, daquele a quem a vida aparece ajustada a uma aparência. Desse modo, "nunca ter sofrido", significa permanecer na aparência, e essa experiência grega de sofrer o real se dá nas emoções mais apaixonadas e horríveis, que invariavelmente suscitam no herói trágico o agir brutal. 0 coro se refere a uma transposição necessária para que se dê o conhecimento desde um sofrer, é preciso "transpor (...) o umbral da morte". De que morte se fala e como é possível entendê-la? Podemos entender essa morte como o mesmo sofrer. Transpor o limiar da morte diz o mesmo que o instante de declinar de uma aparência, fazer surgir-se em re-velação, tal como kairós. 0 coro fala da morte do próprio Édipo. Novamente, não se deve crer que essa morte indica o fim do viver de Édipo, mas o declínio da sua aparência, que se encoberta para a exposição do ser.

O caráter de Édipo, a despeito da re-velação de sua origem e destino terrível, não é outro senão o do próprio herói trágico. Édipo é grande não pela posição que ocupa no mundo - pois essa posição é uma ilusão fruto da aparência em que vive -, mas porque congrega em si as mais altas potencialidades humanas, na busca incansável da verdade. Ora, fosse Édipo uma personagem banal, o que lhe impediria de interromper sua investigação quando esta despontava para o desvelamento de seu destino terrível, que certamente lhe garantiria a morte ou o exílio? Édipo não aceita seu destino, ele o 
celebra, ele o conclama desde o estigma da dor. De olhos perfurados e entregue à cegueira e à desgraça, Édipo abre os portões da cidade para mostrar-se a ela como originariamente é. E o coro, quando o vê, reconhece seu destino encaminhando (ver. 1312)

CORO:

A um horror não audível, não visível.

Isto, este "horror", como um grande cataclismo de terra, originase desde o cerne de Édipo, que é incapaz de fazer com que os cidadãos ouçam e vejam aquilo que seu próprio ser lhe assegura, mas que se dá unicamente na mesma medida em que não se dá por completo, pois permanece na mesma tensão de ocultar e acenar. Não há caminho de volta na decisão do herói trágico, no qual a paixão fundamental dos gregos acende a flama das emoções primitivas, e galga o seu destino, grau mais alto e mais brutal - a paixão de des-vendar o ser. 0 enigma de Édipo conclama o enigma de todo homem, que ainda hoje, ao acelerar a infinitésima partícula, vive perplexo à roda da dinâmica da vida, na qual ele não é mais do que um papelinho com que o vento brinca.

\section{REFERÊNCIA BIBLIOGRÁFICA}

HEIDEGGER, Martin. Introdução à metafísica. Trad. Emmanuel Carneiro Leão. 4⿳a ed. Rio de Janeiro: Tempo Brasileiro, 1991.

. Parmênides. Trad. Sérgio Mário Wrublevski. Petrólis:

Vozes; Bragança Paulista:

EdUSF, 2008.

HEINHARDT, Karl. Sófocles. Trad. Oliver Tolle. Brasília: Editora Universidade de Brasília, 2007. 
HERÁCLITO. Fragmentos. Trad. Emmanuel Carneiro Leão. Rio de Janeiro: Tempo Brasileiro, 1980.

SÓFOCLES. Édipo rei. Trad. Trajano Vieira. São Paulo: Perspectiva, 2012.

SOUZA, Ronaldes de Melo e. Atualidade da tragédia grega. In: Ensaios de poética e hermenêutica. Rio de Janeiro: Oficina Raquel, 2010. 


\title{
VISÕES DO ORIENTE E DOS IMPÉRIOS; THÉOPHILE GAUTIER E GIUSEPPE VERDI.
}

\section{VIEWS OF THE EAST AND OF EMPIRES: THÉOPHILE GAUTIER AND GIUSEPPE VERDI.}

\begin{abstract}
RESUMO: A ópera Aida (1871), do compositor italiano Giuseppe Verdi (1813-1901), explora um tema pitoresco exótico, a força, a selvageria e a plasticidade dos antigos impérios egípcios, que tanto marcaram as imagens do outro no século XIX e que também podemos encontrar em inúmeras obras românticas, tais como o Romance da múmia (1857) de Théophile Gautier (1811-1872). 0 poeta e romancista francês compartilhou com o compositor um imaginário romântico que fez do Egito um dos espaços mais evocados no século XIX, para uma ambientação pitoresca oriental. Ambos projetam as imagens românticas do antigo Egito que encantaram tantos viajantes e cuja plasticidade muito deve às imagens que foram se formando, a partir de um fundo de textos, documentos, desenhos, interpretações e fabulações criadas por poetas, escritores e pintores. Sua consolidação resulta de processos de dominação política e de representação, em que a literatura e a arte têm um papel primordial. Evocamos, aqui, de que modo os antigos impérios do Egito são reconstruídos por Théophile Gautier em Le Roman de la momie e por Verdi em Aida, na mesma lógica das relações entre a arte e a sociedade.
\end{abstract}

${ }^{1}$ Professora Titular de Língua e Literatura francesa da Universidade Federal do Rio de Janeiro, Bolsista de Produtividade em Pesquisa do CNPq. 
PALAVRAS-CHAVE: criação poética; romantismo; imagens do oriente; Théophile Gautier; Verdi.

ABSTRACT: The opera Aida (1871), by Italian composer Giuseppe Verdi (1813-1901), explores a picturesque and exotic theme: the power, savagery and plasticity of the Ancient Egyptian empires, which marked nineteenth-century images of otherness that can also be found in many romantic works, such as Le Roman de la momie (1857), by Théophile Gautier (1811-1872). The French poet and novelist shared a romantic ideal with the Italian composer that turned Egypt into the most evoked space for an eastern picturesque ambience. Both artists project romantic images of ancient Egypt which enchanted travellers and whose plasticity derived from texts, documents, drawings, interpretations and confabulations created by poets, writers and painters. The consolidation of such images results from processes of political and representational domination, in which art and literature played a key role. In this essay we show how the ancient empires of Egypt were reconstructed by Théophile Gautier in Le Roman de la momie and by Verdi in Aida, under the same logic that governs the relationship between art and society.

KEYWORDS: poetic creation; romaticism; eastern images; Théophile Gautier; Verdi.

Em abril de 2013, na temporada de ópera do Teatro Municipal do Rio de Janeiro, houve cinco récitas da ópera Aida, do compositor italiano Giuseppe Verdi (1813-1901), com inegável sucesso de público. ${ }^{2}$ A ópera de Verdi explora um tema pitoresco exótico, a força, a selvageria e a plasticidade dos antigos impérios egípcios, que tanto marcaram os imaginários do outro no século XIX e que também podemos encontrar em inúmeras obras românticas, tais como o Romance da múmia (1857) de Théophile Gautier (18111872). Romantismo não indicará, aqui, um estilo de época, tal como é definido nos manuais de literatura, e cujos limites temporais são os de uma geração, mas uma formação discursiva moderna,

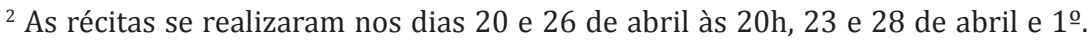
de maio às 17.00 com a direção musical e regência de Isaac Karabtchevsky, a Orquestra Sinfônica e o Coro do Teatro Municipal.
} 
um recorte tributário da arqueologia foucaultiana que contempla períodos da história mais extensos, definidos pelo conceito de longa duração da nova história.

Cabe lembrar, na esteira do ensaio de Edward Saïd, $O$ orientalismo (2007), que o Oriente, em um contexto histórico europeu colonial, é uma construção, em que se confundem épocas e culturas diversas, que vão do Marrocos ao Japão. A consolidação ocidental desta imagem de oriente, com sua face oculta, a de um ocidente civilizado e hegemônico, resulta de processos de dominação política e de representação internalizada em forma de habitus ${ }^{3}$, em que a literatura e a arte têm um papel primordial. Sua plasticidade, que se quer icônica de um esplendor passado, muito deve às imagens que, ao longo dos séculos, foram se formando, graças a um fundo de textos, documentos, desenhos, interpretações e fabulações que devemos aos viajantes, arqueólogos e historiadores, e também a cronistas, poetas, escritores e pintores.

Os costumes e a plasticidade dos antigos impérios do Egito são reconstruídos por Théophile Gautier em Le Roman de la momie (1857) e por Verdi em Aida (1871), com uma inspiração poética associada a um grande cuidado de documentação. Não se trata, contudo, de relatos de viajantes, nem de obra de historiador, e muito menos de ciência política: Gautier e Verdi compartilharam, com muitos de seus contemporâneos, e suas obras contribuíram para formar, um imaginário romântico que fez do Egito dos faraós um dos espaços mais evocados, pelos escritores e artistas do século XIX, para uma ambientação pitoresca oriental. Por outro lado, tanto o romance quanto a ópera não podem ser cortados de seu contexto político, da marcante presença dos franceses no Egito, repercutindo a campanha de Napoleão (1798-1799), no Egito, ou de episódios que são um símbolo das relações entre

\footnotetext{
${ }^{3}$ Um dos conceitos fundamentais da teoria dos campos de Pierre Bourdieu: "système de dispositions durables acquis par l'individu au cours du processus de socialisation qui génère et organise les pratiques et les représentations des individus et des groupes. " - "sistema de disposições duráveis adquiridas pelo indivíduo ao longo do processo de socialização que gera e organiza as práticas e as representações dos indivíduos e dos grupos." (BONNEWITZ, 2002, p. 94, tradução nossa)
} 
europeus e egípcios, como a construção do canal de Suez, que vai de 1859 a 1869 .

0 romance de Gautier e a ópera de Verdi inserem-se neste acervo de imagens compõem um imaginário do Oriente e do Egito, que por sua vez suas criações vieram enriquecer. 0 escritor e o compositor se inspiram de um Egito que foi em grande parte redescoberto, no século XIX, desenhado, repertoriado, classificado, representado, interpretado e valorizado como um patrimônio da humanidade, por viajantes, artistas e arqueólogos ocidentais, em que dois grandes nomes são franceses: Jean-François Champollion (17901832) e Auguste Mariette (1821-1881). Entre os viajantes ilustres que se interessaram pelas grandes descobertas arqueológicas que lá foram realizadas no século XIX, encontramos o Imperador Pedro II, que fez duas viagens ao Egito, em 1871 e 1876, quando visitou o Alto Egito em companhia precisamente de Auguste Mariette.

\section{Théophile Gautier e o Romance da múmia}

O Egito antigo é um tema recorrente entre os autores do romantismo e igualmente presente na obra de Théophile Gautier, desde seu primeiro texto Un repas au désert de l'Egypte (Uma refeição no deserto do Egito, 1831). Há também dois contos, Une nuit de Cléopâtre (Uma noite de Cleópatra, 1838) e Le pied de Momie (O pé da múmia, 1840) (GAUTIER, 1990); destaca-se o dueto de poemas " Nostalgies d'obélisques », publicado no jornal La Presse, em 4 de agosto de 1851 (GAUTIER, 1968, p70). Curiosamente, até a inauguração do Canal de Suez, em 1869, Théophile Gautier não tinha nenhum conhecimento direto do Egito. 0 país, para ele, fazia parte desse oriente imaginário, que fascinou várias gerações e que ele contribuiu para fascinar.

Flaubert e seu amigo Maxime Du Camp, este em missão arqueológica oficial, partem para o Egito em 1849, país que visitaram ao longo de oito meses, indo até o Alto Egito, e de que retornaram, 
como ainda hoje voltam os viajantes, carregados de fotos - as de Maxime du Camp ${ }^{4}$, claro, pois Flaubert detestava fotografias - de sensações e experiências. A estreita amizade de Théo com Gustave Flaubert e Maxime Du Camp, nos anos 1850, aproxima-o ainda mais de um Egito antigo, que já o havia inspirado e com que sempre sonhara: uma breve carta de Maxime du Camp a Théophile Gautier, datada de 31 de março de 1850, estaria na origem dos poemas dos obeliscos.

A Luxor, ô Théo, j'ai beaucoup pensé à vous, et voici pourquoi. - Parce qu'il y a un obélisque ! - Cela peut vous sembler étrange [...] et cependant c'est l'obélisque qui m'a fait songer à vous. - [...] Depuis qu'ils sont séparés, ces deux siamois monolithes s'embêtent de façon désespérante. Celui qui est à Luxor envie le destin de son frère. Celui de Paris est encore plus triste et se désespère en pensant au pays [...]. Cher maître j'ai vu là un beau sujet de vers. ${ }^{5}$

$O$ romance da múmia trata de um tema que corresponde ao enorme interesse dos franceses pelo Egito antigo, que é despertado, sobretudo, pela missão civilizadora de Napoleão e a descoberta de Champollion, o qual, ao decifrar a pedra de Roseta, permitiu a leitura dos hieróglifos, até então indecifráveis. A possibilidade de ler os registros em hieróglifos revoluciona a reconstituição da história antiga do Egito, ao descortinar episódios fabulosos das diversas dinastias dos faraós, que haviam sido conservados em registros

\footnotetext{
${ }^{4}$ Maxime Du Camp, que aprendera a tirar fotos especialmente para esta viagem, publica, em 1852, um livro que resulta desta viagem: Égypte, Nubie, Palestine et Syrie : dessins photographiques recueillis pendant les années 1849, 1850 et 1851, accompagnés d'un texte explicatif et précédés d'une introduction par Maxime Du Camp, chargé d'une mission archéologique en Orient par le ministère de l'Instruction publique, Paris, Gide et Baudry, 1852.

5 “Em Luxor, ó Théo, lembrei muito de você, e eis o motivo. - Porque há um obelisco! Isto poderá lhe parecer estranho [...] e contudo foi por causa do obelisco que lembrei de você . - [...] Desde que foram separados, estes dois monolitos siameses entendiam-se de um modo desesperador. - Aquele que se encontra em Luxor inveja o destino do irmão. Aquele que está em Paris está ainda mais triste e fica desesperado ao lembrar de sua terra [...]. Caro poeta, pensei que seria um belo tema para um poema." (Lov. C 493, ff. 430-431 apud GAUTIER, 1968, p. 70, tradução nossa).
} 
de papiro ou nas paredes de templos e túmulos, destruindo, definitivamente, a secular datação do mundo bíblico, adotada pela Igreja Católica. 0 grand tour ${ }^{6}$ se expande, e a arqueologia naquelas terras bíblicas torna-se uma paixão. Novos temas aparecem na pintura, na literatura e na música, permitindo que se alargue o universo da erudição e do mundo antigo.

O romance da múmia foi publicado, em sua primeira versão, em 1857, no formato de folhetim, no Moniteur Universel, de 11 de março a 6 de maio (LOVENJOUL, 1887, p. 125), e depois, em 1858, em formato de livro, pela editora Hachette. ${ }^{7}$ É dedicado a Ernest Feydeau, autor da Histoire des usages funèbres et des sépultures des peuples anciens (História dos usos fúnebres e das sepulturas dos povos antigos), livro publicado em 1856, que teria sido o inspirador deste romance. 0 historiador teria colocado à disposição de Gautier a documentação necessária para sua fidelidade à história e aos costumes do Egito antigo, conforme fica registrado na dedicatória:

A M. Ernest Feydeau. Je vous dédie ce livre, qui vous revient de droit ; en m'ouvrant votre érudition et votre bibliothèque, vous m'avez fait croire que j'étais savant et que je connaissais assez l'Egypte antique pour la décrire ; sur vos pas, je me suis promené dans les temples, dans les palais, dans les hypogées, dans la cité vivante et dans la cité morte; vous avez soulevé devant moi le voile de la mystérieuse Isis et ressuscité une gigantesque civilisation disparue. L'histoire est de vous, le roman est de moi ; je n'ai eu qu'à réunir par mon style, comme par un ciment

\footnotetext{
${ }^{6}$ Nos séculos XVII, XVIII e XIX, longa viagem pela Europa, sobretudo Itália e Grécia que vem complementar a educação de jovens rapazes burgueses. Esta viagem, que é a origem do turismo, está voltada para visitas a sítios arqueológicos, igrejas, palácios e ateliês de artistas, e também bailes, tavernas e lupanares.

${ }^{7}$ Lovenjoul registra: "Voici une curieuse dédicace inédite d'un exemplaire de la première édition de cet ouvrage (Hachette, 1858). Je dédie ce roman pharmaceutique et ganaliforme à l'embaumeur F. Silas, mon ami insulaire et bientôt continental. Théophile Gautier. Londres, Panton-square, 9 juin 1862." - "Eis um curioso autógrafo inédito de um exemplar da primeira edição desta obra (Hachette, 1858). Dedico este romance farmacêutico e ganaliforme ao embalsamador F. Silas, meu amigo insular e em breve continental. Théophile Gautier. Londres. Panton-square, 9 de junho de 1862." (LOVENJOUL, 1968, p. 127, tradução nossa) Disponível em http:// gallica.bnf.fr/ark:/12148/bpt6k8840n. Acesso em 05 de novembro 2014.
} 
de mosaïque, les pierres précieuses que vous m'apportiez. Th. $G^{8}$

Neste romance, sonhos, devaneios e visões noturnas reatualizam elementos próximos do que Gautier chamava de fantasias, ou seja, narrativas fantásticas; mas, graças a este respeito documental, a obra foi recebida como um romance histórico. Gautier, sempre fiel a seus fantasmas, faz da ambientação dos ritos funerários egípcios o tema perfeito para representar o desafio que se coloca à narrativa literária. Em suas descrições ele joga com simulacros pelos quais o leitor se apaixona, do mesmo modo que o jovem Lorde Evandale se apaixona pela múmia do título, Tahoser. Filha do grande sacerdote, ela é desenterrada pelos europeus de um túmulo até então inviolado: “Une tombe que n'auront fouillée ni les rois pasteurs, ni les Mèdes de Cambyse, ni les Grecs, ni les Romains, ni les Arabes, et qui nous livre ses richesses intactes et son mystère vierge [...]. »9.

Ao penetrar no túmulo, o jovem inglês tem a impressão de que havia voltado no tempo e que a história se anulara projetando-o em um passado que se torna seu presente: "Une main invisible avait retourné le sabier de l'éternité, et les siècles, tombés grain à grain comme des heures dans la solitude et la nuit, recommençaient leur chute." ${ }^{10}$ A "mão invisível" é aquela do autor e seu gesto representa

\footnotetext{
8 "Ao Senhor Ernest Feydeau. Eu lhe dedico este livro, que é seu por direito; ao me abrir sua erudição e sua biblioteca, o senhor me levou a crer que eu era um erudito e conhecia suficientemente o Egito para o descrever; seguindo seus passos, andei pelos templos, palácios, hipogeus, pela cidade viva e pela cidade morta; o senhor levantou para mim o véu da misteriosa Isis e ressuscitou uma gigantesca civilização extinta. A história é sua, eu escrevi o romance; apenas tive que reunir, com meu estilo, como usando um cimento de mosaico, as pedras preciosas que o senhor me trazia. Th. G." (GAUTIER, 1858, dedicatória, s.p., tradução nossa). Disponível em: http://catalogue.bnf.fr/ark:/12148/cb30490246s. Acesso em 4 de novembro 2014.

9 "Um túmulo que não terá sido violado nem pelos reis pastores, nem pelos medos de Cambises, nem os gregos, nem os romanos, nem os árabes, e que nos entrega suas riquezas intocadas e seu mistério virgem [...]. ». (GAUTIER, 1858, p. 2 , tradução nossa).

10 "Uma mão invisível havia invertido a ampulheta da eternidade, e os séculos de areia, escorrendo grão por grão como as horas na solidão e na noite, recomeçavam a cair.". (GAUTIER, 1858, p. 35-36, tradução nossa).
} 
o movimento mesmo da leitura que permite ao leitor tornar-se um viajante do tempo e penetrar em outros espaços-tempos. A distância de séculos e de culturas tão distantes e díspares produz, mais uma vez, pela mão de Gautier que vira a "ampulheta da eternidade", a narrativa de um amor absoluto e impossível, sempre associado à beleza.

Lorde Evandale é um belo jovem, de uma beleza perfeita, pura mas fria, como uma efígie de cera: " [...] il portait partout avec lui [...] une beauté dont on ne pouvait rien dire, sinon qu'elle était trop parfaite pour un homme. En effet, sa tête pure, mais froide, semblait une copie en cire de la tête de Méléagre ou de l'Antinoüs. ${ }^{11}$. 0 rapaz, a pós a leitura de sua história apaixona-se pela múmia que se encontra naquele túmulo. É descrita a beleza intacta da jovem morta, que vivera muitos séculos antes de Cristo:

Jamais statue grecque ou romaine n'offrit un galbe plus élégant; les caracteres particuliers de l'idéal égyptien donnaient même à ce beau corps si miraculeusement conservé une sveltesse et une légèreté que n'ont pas les arbres antiques. ${ }^{12}$

O egiptólogo alemão Rumphius, que acompanhara o jovem lorde em sua aventura arqueológica, depois de três anos de estudos, finalmente, decifra a história de Tahoser, nos papiros que haviam encontrado. 0 relato do alemão, romance da múmia, é uma narrativa dentro da narrativa (mise-en-abyme), como a múmia em seu sarcófago, relato que vem justificar o título do romance. Esta estratégia narrativa, a cena de uma simples transcrição de um relato que foi encontrado, apaga a presença do autor e confere à narrativa,

\footnotetext{
11 «[...] ele levava sempre aonde ia [...] uma beleza de que nada se podia afirmar a não ser que era perfeita demais para um homem. Com efeito, sua cabeça pura, mas fria, parecia uma cópia de cera da cabeça de Meléagro ou de Antínoo. » (GAUTIER, 1858, p. 3-4, tradução nossa).

12 « Jamais estátua grega ou romana apresentou curvas mais elegantes; e até mesmo os traços específicos do ideal egípcio conferiam a este belo corpo, tão milagrosamente conservado, uma finura e uma leveza que não possuem as árvores antigas." (GAUTIER, 1858, p. 55, tradução nossa).
} 
para o leitor de seu tempo, uma legitimidade de documento, tal como o define Jacques Le Goff (1924, p.526-527) :

O documento que, para a escola positivista do fim do século XIX, será o fundamento do fato histórico, ainda que resulte da escolha, de uma decisão do historiador, parece apresentar-se por si mesmo como prova histórica. A sua objetividade parece opor-se à intencionalidade do monumento. Além do mais, afirma-se essencialmente como um testemunho escrito.

Tahoser fora enterrada como rainha do Egito, no vale dos Reis e não no vale das Rainhas, mais precisamente no túmulo que havia sido preparado para o Faraó Ramsés, aquele que teria sido engolido pelo Mar Vermelho, quando corria ao encalço de Moisés. Este episódio bíblico também é narrado por Gautier, no romance, de que constitui a última parte. A história tecida de amores impossíveis, do Faraó Ahmosis por Tahoser, e de Tahoser por um jovem judeu, Poëri, serve de pretexto para o talento descritivo do autor. Este nos transporta para as cenas que descreve, por sua qualidade plástica. E como quem não quer nada, aqui e ali, Gautier insere críticas à França de seu tempo e aos europeus civilizados. A sofisticação dos ritos fúnebres do antigo Egito serve de pretexto para uma crítica bem humorada à França contemporânea:

Quelle touchante coutume, dit le docteur Rumphius, enthousiasmé à la vue de ces trésors, d'ensevelir avec une jeune femme tout son coquet arsenal de toilette! [...] à côté des Egyptiens, nous sommes vraiment des barbares; emportés par une vie brutale, nous n'avons plus le sens délicat de la mort. [...]

- Peut-être, répondit lord Evandale tout pensif, notre civilisation, que nous croyons culminante, n'est-elle qu'une décadence profonde, n'ayant plus même le souvenir historique des gigantesques sociétés disparues. Nous sommes stupidement fiers de quelques ingénieux mécanismes récemment inventés, et nous ne pensons pas aux colossales splendeurs, aux énormités irréalisables pour 
tout autre peuple, de l'antique terre des Pharaons. Nous avons la vapeur; mais la vapeur est moins forte que la pensée qui élevait ces pyramides [...].13

Em um constante exercício de seu estilo descritivo, Gautier nos leva a contemplar o Nilo, a cidade de Tebas (com os templos de Luxor e Karnac), a entrada triunfal do faraó, que retorna vitorioso de combates, os músicos e seus instrumentos, o esplendor dos palácios, com seus rituais, grandes pinturas de história. E em écfrasis de pequenas cenas de gênero, os humildes casebres e os costumes dos homens e das mulheres do povo. Ao descrever uma das salas do palácio do faraó, Gautier projeta em suas paredes uma imagem que ele chama de "desfile etnográfico", na qual vemos representantes de diferentes etnias; e neste desfile, o europeu vem por último e é « o mais selvagem de todos » (GAUTIER, 1858, p. 246-247).

Ao concluir o romance, o pudor de Gautier quanto a qualquer expressão sentimental leva-o a brincar com os clichês referentes a tipos nacionais, que caracterizam a literatura de consumo no século XIX, mencionando a excentricidade dos ingleses; o jovem lorde apaixonado pela bela múmia, por toda a eternidade, "retrospectivamente", jamais se casou. E o narrador comenta filosoficamente: "Il y a pourtant des folies anglaises moins motivées que celle-là".14

\footnotetext{
13 "Que costume tocante, disse o doutor Rumphius, entusiasmado ao ver esses tesouros, aquele de enterrar com uma jovem todo seu elegante arsenal de toalete! [...] comparados aos egípcios, somos realmente bárbaros; arrastados por uma vida brutal, perdemos o delicado sentido da morte. [...] - Talvez, respondeu Lorde Evandale profundamente pensativo, nossa civilização, que pensamos ser culminante, seja apenas uma decadência profunda, não tendo nem conservado a lembrança histórica das gigantescas sociedades que desapareceram. Temos um orgulho estúpido de alguns mecanismos engenhosos recentemente inventados e não lembramos os colossais esplendores, cuja enormidade é irrealizável para qualquer outro povo. Temos o vapor; mas o vapor é menos forte do que o pensamento que erguia estas pirâmides." (GAUTIER, 1858, p. 50-51, tradução nossa).

14 "Contudo há loucuras inglesas menos motivadas do que esta." (GAUTIER, 1858, p. 302, tradução nossa).
} 
Enquanto Gautier e escreve e publica seu romance, o canal de Suez está sendo projetado. 0 Egito, mais do que nunca está na moda, sobretudo graças à repercussão das primeiras descobertas arqueológicas de Auguste Mariette nas escavações de Sakkhara, que enriqueceram o acervo do Louvre com milhares de peças.

\section{Giuseppe Verdi e Aida}

A gênese de Aida, seu processo de criação, ilustram de modo exemplar a circulação de ideais políticos, temas e estéticas, e a não menos intensa circulação de escritores, artistas e músicos, entre a Itália e a França, no século XIX. 0 próprio Verdi viajou inúmeras vezes a Paris, cidade em que viveu por longos períodos, sem ser objeto de curiosidade ou reprovação carola, com sua companheira, a soprano Giuseppina Strepponi (1815-1897). ${ }^{15}$

Várias óperas de Verdi retomam personagens e argumentos do repertório dramático francês do romantismo: Ernani (1844), inspirada pela peça homônima Hernani (1830), de Victor Hugo; o tema de Rigoletto (1851) provém de Le Roi s'amuse (0 rei se diverte, 1832), igualmente de autoria de Victor Hugo ${ }^{16}$, enquanto La Traviata (1853) retoma o argumento do romance de Alexandre Dumas filho, La Dame aux Camélias (A dama das Camélias,1848), que havia sido adaptado para o teatro em 1852. A Ópera de Paris tem laços estreitos com os gêneros dramáticos românticos, cujas intrigas inspiram os compositores (NAUGRETTE, 1981, p.84-85).

A recepção de Verdi, na França, em um primeiro momento, passa por grupos de franceses que apoiam a causa da unificação italiana e, por outro lado, por sua fama de ter renovado a tradição operística

${ }^{15}$ Giuseppina Strepponi manteve, por muitos anos, uma relação com Giuseppe Verdi, que começa em 1846; eles só se casarão em 1859.

${ }^{16}$ A peça estreia dia 22 de novembro de 1832 e, logo após a primeira apresentação, foi proibida por imoralidade. Verdi modifica os títulos das personagens nobres, seus nomes, assim como a localização da ação, para fugir à censura (NAUGRETTE, 2011, p. nota a). 
apegada à fórmula do Bel Canto. Deve também ser mencionada a atuação de críticos folhetinistas, como o compositor e maestro Hector Berlioz (1803-1869), o maior crítico musical da França, e o próprio Théophile Gautier.

Gautier era considerado o maior crítico em seu tempo, na França, não apenas de artes plásticas, mas de artes dramáticas e espetáculos de dança, líricos e de ópera, em La Presse (1836-1855) e posteriormente no Moniteur Universel (1855-1868). As posições do escritor e do compositor, enquanto críticos de música, são bem contrastadas: Gautier é um entusiasta da ópera italiana, embora considere os libretos "em sua maioria incomprehensíveis ou estúpidos" ${ }^{17}$, enquanto Berlioz prefere a escola alemã de música ${ }^{18}$. Assim, Gautier acompanhou a trajetória de Giuseppe Verdi, de que sempre foi um defensor entusiasmado.

Com sua potência criadora e a visão da ópera como espetáculo em que se integram história, libretto, cantores e músicos, Verdi vai deixando de lado a fórmula de óperas em que a trama é um mero pretexto para criar momentos fortes que valorizem as áreas. Ele cria óperas que assumem um aspecto dramático, no qual a orquestra tem um grande protagonismo. Suas obras seduzem o exigente público parisiense e o imperador Napoléon III, a tal ponto que em 1853 lhe é encomendada uma ópera para a abertura da Exposição Universal

\footnotetext{
17 “[...] aucun ouvrage n'a complètement réussi aux Bouffes, à l'exception de Donizetti, qui, avec Rossini et Bellini, composent pour ainsi dire tout le répertoire. - La faute n'en est pas au directeur, qui a consciencieusement fait jouer à Paris tout ce qui avait réussi sur les scènes d'Italie. On doit en accuser un peu les compositeurs, et beaucoup les livrets, inintelligibles ou stupides pour la plupart, ce qui choque toujours vivement le public français. " "[...] obra alguma teve um real sucesso no teatro de Bouffes, excetuando-se Donizetti, o qual com Rossini e Bellini, compõe de certo modo todo o repertório. - Não é por culpa do diretor, que fez conscienciosamente representar em Paris tudo o que havia sido um sucesso nos palcos da Itália. Os responsáveis são, um pouco, os compositores e, muito, os libretos, os quais em sua maioria são incompreensíveis ou estúpidos." (La Presse, 30 de setembro de 1844, p. 2, tradução nossa).

18 Berlioz, polêmico e irônico, é muito mais crítico em relação à escola italiana de música, sobretudo desde sua estada na Itália, em 1831, após ter ganho o Prêmio de Roma, quando se decepciona com a situação decadente da música e dos músicos (BERLIOZ, 1991).
} 
de 1855. Verdi passa então três anos em Paris e compõe, com um libreto de Eugène Scribe (1791-1861) e Duveyrier (1803-1866), Les Vêpres siciliennes, que foi traduzido, meses depois por Caimi, para a Scala de Milão: I Vespri Siciliani (1856). A fama do compositor já fizera de sua obra um sucesso internacional, enquanto os encantos da ópera italiana chegam ao Egito.

O primeiro responsável pela gênese de Aida foi o sultão Khédive Ismail. ${ }^{19}$ Formado na admiração da cultura europeia, ao se tornar vice-rei do Egito, em 1763, em seu projeto de modernizar o país, ele assegura a realização do projeto de Ferdinand de Lesseps de abrir o canal de Suez, finalmente inaugurado em 17 de novembro de 1869. Ele foi, também, diretamente responsável pela construção da ópera do Cairo, para celebrar aquele acontecimento e indiretamente pelo fato de Verdi ter sido o compositor solicitado para compor uma ópera para sua inauguração.

O Khédive Ismail tinha o projeto de inaugurar o Canal de Suez com uma série de festividades solenes, para as quais convidara todos os soberanos da Europa. Estas festividades foram organizadas por Auguste Mariette, que já havia sido responsável pelo pavilhão do Egito na Exposição Universal de Londres, em 1862, e na Exposição Universal de 1867, em Paris. Arqueólogo de fama incontestável, naquela altura ele já não mais era um funcionário do Louvre, mas do governo egípcio; fora nomeado Inspetor Geral e Conservador dos Monumentos do Egito e era responsável por políticas de conservação e proteção aos vestígios do Egito antigo. ${ }^{20}$

o Khédive lhe encomenda, então, uma ópera egípcia que seria representada na inauguração do Grande Teatro do Cairo, construído por ocasião das festividades do Canal de Suez. O sultão, apaixonado por ópera, e que conhecia todo o repertório da ópera italiana, desejara dar ao Egito uma sala com padrões europeus e que apresentasse os melhores recursos de conforto e acústica,

\footnotetext{
${ }^{19} \mathrm{O}$ Egito fazia parte do império otomano; Khédive era o título honorífico que era concedido aos vice-reis do Egito entre 1867 e 1914.

${ }^{20}$ Com esta finalidade ele cria o Museu de Boulaq (1863-1889), cujo acervo hoje se encontra no Museu egípcio do Cairo, inaugurado em 1902.
} 
em seu tempo. Este teatro, que foi chamado de Ópera Khédival e que, infelizmente, foi destruído em um incêndio em 1971, deveria ser inaugurado com uma obra que celebrasse a antiga história do Egito. Para a trama de autoria de Mariette Pacha, de quem o Khédive exigira um enredo, o vice-rei exigiu também o maior compositor de óperas em seu tempo, Verdi. Esta é a origem de Aida. (ISON, 1999, p. 278).

No site oficial da Ópera do Cairo, há o registro da construção da Ópera Khédival e da gênese da ópera Aida, cujo ponto de partida, como já foi mencionado, teria sido um projeto do Khédive:

Par ailleurs et avant l'achèvement de la construction, il a cherché à présenter une ouvre qui traduit [sic] l'histoire de l'Egypte. Il a choisi une ancienne histoire égyptienne écrite par Mariette pacha et a demandé au poète italien Ghislanzoni de la transformer en pièce d'opéra et de [sic] son compatriote, le grand musicien Verdi, de composer sa musique. Par conséquent, cette combinaison impeccable a engendré au monde l'opéra d'Aida. [...] Et malgré les efforts effectués et la volonté de Khédive Ismail, l'opéra a été inauguré en novembre 1869, lors de la célébration de l'ouverture du Canal de Suez par un autre spectacle, c'était l'opéra de Rugolotto [sic] toujours composé par Verdi. ${ }^{21}$

O maestro, de início, não aceitara o convite, recusa contornada por um hábil artifício do diretor da Ópera Cômica de Paris, Camille du Locle (1832-1903). Este lhe encaminha o argumento de Aida, sem nome de autor, acompanhado por uma carta de Mariette, a qual traz em seu post-scriptum a seguinte frase: "si le signor Verdi

\footnotetext{
${ }^{21}$ « Por outro lado e antes de terminar a construção, ele procurou apresentar uma obra que traduzisse a história do Egito. Ele escolheu uma antiga história egípcia, escrita por Mariette Pacha e pediu ao poeta italiano Ghislanzoni que a transformasse em libreto e que seu compatriota, o grande músico Verdi, compusesse a música. Por conseguinte, esta impecável combinação gerou para o mundo a ópera Aida [...] E apesar dos esforços empenhados e da vontade de Khédive Ismail, a ópera foi inaugurada em novembro de 1869, por ocasião da abertura do Canal de Suez por outro espetáculo, a ópera Rigoletto, igualmente composta por Verdi." (Disponível em http://www.cairoopera.org/history.php. Acesso em 15 de agosto de 2013, tradução nossa)
} 
n'accepte pas, Son Altesse vous prie de frapper à une autre porte... Elle pense à Gounod et aussi à Wagner."22

Não é bem assim que a história é contada na biografia de Verdi, de autoria de seu contemporâneo Pougin (1886). 0 maestro teria sido seduzido pelo convite e aceita o régio contrato:

Verdi fut séduit tout d'abord: d'une part, par la grandeur de la donnée générale; de l'autre, par l'idée première de la scène du jugement, à laquelle on doit le tableau étrange et puissamment dramatique qui forme le dénouement. Il comprit tout le parti qu'on pouvait tirer musicalement d'un tel sujet, et n'hésita pas à l'accepter. ${ }^{23}$

Repugnara-lhe a encomenda de um vice-rei déspota? Penso que não, ele já atendera ao convite de Napoleão III, e aceitara o convite do Czar, em 1862, para uma apresentação em São Petersburgo da ópera La forza del destino, além disso, o Khédive era um tirano progressista: almejava libertar o Egito da Sublime Porta - a dominação turca - e, além disso, era um grande amador de ópera. 0 mais provável é que Verdi temesse a travessia por mar (POUGIN, 1886, p. 221). Foi então feito um arranjo para a dupla estreia da ópera, uma no Cairo e a outra em Milão, no La Scala, logo após aquela do Cairo. A primeira récita ocorre em 24 de dezembro de 1871 e a segunda, seis semanas depois, em 7 de fevereiro de 1872 (POUGIN, 1886, p. 232).

O sucesso de Aida foi imenso e imediato, tanto no Cairo quanto em Milão. Depois em seu giro d'Italia e nas capitais europeias, obtém um estrondoso sucesso.

\footnotetext{
22 "caso o signor Verdi não aceite [o convite], sua alteza lhe pede que o Senhor bata em uma outra porta... Ela está pensando em Gounod e também em Wagner." (ISON, 1999, p. 279, tradução nossa).

23 "Verdi foi seduzido logo: por um lado, pela grandeza geral da proposta, e, por outro lado, pela ideia primeira do julgamento, à qual se deve o quadro estranho e poderosamente dramático que forma o desenlace. Ele compreendeu todo o partido que ele poderia tirar, musicalmente, de um tema como esse e não hesitou em aceitar." (POUGIN, 1886, p. 217, tradução nossa).
} 
Le soir même de la première représentation, après le deuxième acte, une députation d'artistes s'approcha de Verdi et lui offrit un superbe sceptre en ivoire orné d'une étoile en diamants, semblable à celui que porte le roi d'Egypte dans l'opéra ; sur ce sceptre était tracé en rubis le nom d'Aida, tandis que celui de Verdi se détachait en pierres précieuses sur une branche de laurier. ${ }^{24}$

Aida é uma ópera bastante complexa, para alguns é a última das grandes óperas; sua criação envolveu, além do compositor, vários colaboradores, a começar pelo autor do enredo, Auguste Mariette. 0 argumento de Aida teria sido desenvolvido, em prosa, cena por cena, por Camille du Locle, que criou os diálogos, em Bussetto, sob a atenta supervisão de Verdi: "L'idée du finale du dernier acte, avec ses deux scènes superposées, lui appartient particulièrement.."25

A tradução em versos italianos é de autoria do poeta italiano Antonio Ghislanzoni (1824-1893). Alguns anos depois, os versos foram traduzidos para o francês, para a estreia de Aida na Ópera de Paris. Du Locle, em carta enviada ao jornal L'Italia, de Roma, em 1880 , por causa de uma polêmica, na imprensa italiana, envolvendo autorias esclarece a participação de cada um (POUGIN, 1886, p. 219220). Encerrada a composição do libretto, Verdi criou a partitura.

Para a composição musical, em um primeiro momento, Verdi pensa em reconstituir a música do Egito dos faraós e informa-se junto a Mariette sobre os instrumentos egípcios antigos e as danças sagradas; apesar das descrições fornecidas por Mariette, face às lacunas de documentação, Verdi deixa de lado este projeto e tenta criar uma música “à moda egípcia”, com temas turcos que são destinados a produzir uma cor local. Ele encomenda, então, a um

24 "Já na noite de estreia, depois do segundo ato, uma delegação de artistas aproximou-se de Verdi e ofereceu-lhe um soberbo cetro de marfim, adornado com uma estrela de diamantes, semelhante àquele do rei do Egito na ópera; no cetro havia sido incrustado em rubis o nome de Aida, enquanto o nome de Verdi se destacava com pedras preciosas em um ramo de louro." (POUGIN, 1886, p. 232, tradução nossa).

25 "A ideia do finale do último ato, com suas duas cenas superpostas, lhe pertence particularmente." (POUGIN, 1886, p. 219, tradução nossa). 
artesão de Milão réplicas das trombetas do Egito, que, conforme narra Plutarco, "lembravam o grito dos burros" (ISON, 1999, p. 280).

A ópera envolveu grandes dificuldades técnicas para a construção de cenários, produção de objetos de cena, armas e joias, assim como para a confecção de figurinos, todos desenhados por Mariette, o qual exigiu, nos mínimos detalhes, a máxima fidelidade histórica. Para inspirar-se, o arqueólogo se recolhera no templo de Ísis, na ilha de Philae, no Egito. Acessórios e maquinaria foram confeccionados no Cairo, cenários e figurinos, em Paris. Como a História atravessa certos sonhos, com a guerra franco-prussiana de 1870, cenários e figurinos ficaram presos na capital de França sitiada e a ópera do Cairo, afinal, foi inaugurada, como já foi mencionado, com outra composição de Verdi, a ópera Rigoletto.

Como em Nabucco (1842), reencontramos, em Aida, a solenidade dos sacerdotes, o coro das massas, a dramaticidade do grupo de escravos. A minissérie da R.A.I, Giuseppe Verdi, sua vida, sua obra, aponta uma novidade: a sensualidade da ópera (GIUSEPPE VERDI, 1982). Certamente um ingrediente indispensável do imaginário romântico de oriente, que confunde escravas e concubinas, danças rituais e a beleza de corpos nus, Egito antigo e haréns muçulmanos.

A trágica paixão que une Aida, uma princesa da Etiópia, escrava no Egito, a um general egípcio, Radamès, é um topos dramático muito conhecido. A personagem dividida entre a lealdade a seu pai e a paixão amorosa por Radamès reatualiza o drama de Chimène, no El Cid (1637) de Corneille (1606-1684), dividida entre o dever para com a memória de Don Gomez e o amor por Don Rodrigue. Da mesma peça, reconhecemos o orgulho e o amor frustrados da antagonista de Aida, a filha do Faraó, apaixonada por Radamès, que reedita a personagem da Infanta espanhola. 0 cruel destino dos amantes, Aida condenada a ser enterrada viva e Radamès que a segue para compartilhar seu castigo, é o castigo que Creonte reservara a Antígona, na peça homônima (cerca de 442 a.C) de Sófocles. 


\section{0 triunfo do faraó}

No contexto deste ensaio, não caberia um cotejo ponto por ponto das sequências do romance com as cenas da ópera, nem é nosso objetivo um estudo comparativo de tramas. Na perspectiva proposta, de construção de imaginários de impérios, em uma ambientação de um Egito oriental, destaca-se o triunfo do faraó, presente nas duas obras. A representação do poder e do esplendor político, fundamentado em um poderio bélico, no Romance da múmia e em Aida, está fundamentalmente concentrada na figura do faraó, que retorna vitorioso de suas batalhas e nas cenas que compõem o desfile de guerreiros, em que ressaltamos a presença dos sacerdotes.

$\mathrm{Na}$ ópera, os diferentes grupos que ocupam sucessivamente o palco, em um triunfo que é mais romano do que egípcio, desfilam em uma ordem muito próxima daquela que lemos no Romance $d a$ múmia. Na obra de Gautier, primeiramente, é descrita a multidão que espera o retorno do rei. Abrindo o desfile, os sacerdotes, seguidos por soldados e altas personalidades. Contrastando com esse grupo, temos mulheres semidespidas, com os filhos pequenos no colo, extremamente pobres, e ainda, belas mulheres abastadas, acompanhadas por três ou quatro criadas. Tahoser desloca-se, junto com a multidão, para ver a chegada do faraó, que é precedida por um rumor extraordinário, provocado por instrumentos, carros de guerra, e depois a infantaria, com o trepidar dos passos dos combatentes. Abrem o desfile militar os músicos, seguidos pelos aliados e por último, temos a descrição do botim:

L'avant-garde des musiciens s'arrêta quelques instants; des colléges [sic] de prêtres, des députations des principaux habitants de Thèbes [...] se rangèrent en haie dans les poses du respect le plus profond, de manière à laisser le passage libre au cortège.

La musique, qui, a elle seule, eût pu former une petite armée, se composait de tambours, de tambourins, de trompettes et de sistres. 
Le premier peloton passa, sonnant une retentissante fanfarre de triomphe dans ses courts clairons de cuivre brillants comme de l'or. ${ }^{26}$

Em Aida (II, 2), vemos em primeiro lugar o faraó, os sacerdotes, seguidos pelos feitores armados com chicotes que conduzem os escravos; há um número de dança e depois o desfile de tropas, precedidas pela fanfarra: a infantaria, carros de guerras, carroças carregando troféus e estátuas de divindades, a cavalaria, os prisioneiros de guerra.

Assim como no romance de Gautier, as trombetas assumem um relevo especial, na Marcia trionfale (Marcha triunfal, II, 2), também conhecida como marcha das trombetas; tratase da adaptação de trombetas encomendadas por Verdi, que foi chamada de trombeta tebana exatamente a partir da representação de Aida, e que hoje também é chamada de trombeta tebana (OPHICLÉDIDE 2009).

Associam-se, aqui, os dois fortes elementos musicais e dramáticos da formação juvenil de Verdi: a música sacra que acompanha rituais religiosos e as marchas tocadas por bandas militares. Estas operam como metonímias, respectivamente, da Igreja e do Estado. Sacerdotes e governantes que se confundem com chefes guerreiros representam, na obra de Verdi, aqui, duas instituições autoritárias, as quais, juntamente com a família burguesa e seus valores, sacrificam as grandes paixões.

\section{Considerações finais}

0 romance e a ópera, em uma abordagem meramente

\footnotetext{
26 "A vanguarda dos músicos parou por alguns instantes; colégios de sacerdotes, representantes dos principais habitantes de Tebas [...] abriram alas, na atitude do mais profundo respeito de modo a deixar passar o cortejo. A música, que sozinha poderia formar um pequeno exército, compunha-se de tambores, tamborins, trombetas e sistros. O primeiro pelotão passou, tocando uma retumbante fanfarra de triunfo em seus curtos clarins reluzentes como ouro.” (GAUTIER, 1858, p. 102, tradução nossa).
} 
temática, parecem não trazer nenhum registro do contexto histórico de sua criação. E as imagens mesmas que projetam do antigo Egito são imagens que nos habituamos a chamar de românticas, aquelas que encantaram, e continuam encantando tantos viajantes ocidentais. Esse Egito antigo, hoje de turismo de massa, das pirâmides, da esfinge, dos túmulos de faraós e dos templos ao longo do rio Nilo, como aquele de Luxor, é um Egito que os arqueólogos do longo século XIX descobriram literalmente, desencavando-o da areia, e que se confunde, para nós, com imaginários de que já fazem parte estes mesmos viajantes, reais ou saídos da ficção, como as personagens de Morte sobre o Nilo (1937), de Agatha Christie.

Ao examinarmos de perto a cena enunciativa ${ }^{27}$ das duas obras, vemos que, embora aparentemente esteja distante no espaço e no tempo da Europa do século XIX, o antigo Egito dos faraós assume, na tradição literária, tanto aquela das narrativas orientalistas quanto a dos preceitos aristotélicos referentes à tragédia, um valor alegórico, de encenação de espaços de poder e crítica política. Essa crítica ultrapassa uma postura de oposição ao Segundo Império francês, no que se refere a Théophile Gautier, que detestava notoriamente qualquer envolvimento político, e ainda não se confunde com o traço de resistência ao Império austríaco, na ópera de Giuseppe Verdi. Talvez, entretanto, com um impacto que vem em parte pelo fato de integrarem obras que, por sua permanência no cânone, recebemos hoje cortadas de um contexto histórico e político direto, essas imagens de Egito permaneçam investidas, em nossos dias, do potencial de desvelar a crueldade dos poderes

\footnotetext{
${ }^{27}$ Cena enunciativa ou cena de enunciação, noção vinculada à análise do discurso, formulada por Dominique Maingueneau: "[...] en parlant de 'scène d'énonciation', on met l'accent sur le fait que l'énonciation advient dans un espace institué, défini par le genre de discours, mais aussi sur la dimension constructive $d u$ discours, qui se 'met en scène', instaure son propre espace d'énonciation. ” - “ [...] ao nos referirmos a 'cena de enunciação', acentuamos o fato de que a enunciação ocorre em um espaço instituído, definido pelo gênero do discurso, mas também pela dimensão construtiva do discurso, que se 'encena', instaura seu próprio espaço de enunciação.” (CHARAUDEAU \& MAINGUENEAU, 2002, s.v. Scène d'énonciation, p.515, tradução nossa, destaques do autor).
} 
arbitrários de todos os regimes autoritários, de que é feita a alegoria construída a partir do imenso poderio dos faraós.

\section{REFERÊNCIAS BIBLIOGRÁFICAS}

BERLIOZ, H. Mémoires. Paris : Flammarion, 1991.

BONNEWITZ, P. Pierre Bourdieu ; vie, oeuvre, concepts. Paris : Ellipses, 2002.

CHARAUDEAU, P. \& MAINGUENEAU, D. Dictionnaire d'analyse du discours. Paris : Seuil, 2002.

DU CAMP, M. Égypte, Nubie, Palestine et Syrie : dessins photographiques recueillis pendant les années 1849, 1850 et 1851, accompagnés d'un texte explicatif et précédés d'une introduction par Maxime Du Camp, chargé d'une mission archéologique en Orient par le ministère de l'Instruction publique. Paris : Gide et Baudry, 1852.

Disponível em http://gallica.bnf.fr/ark:/12148/ btv1b86260711.r=.langPT. Acesso em 31 de agosto de 2013.

FEYDEAU, E. Histoire des usages funèbres et des sépultures des peuples anciens. Paris : GIDE \& BAUDRY, 1856.

Disponível em http://books.google.com.br/book. Acesso em 21 de novembro 2014.

GAUTIER, T. Feuilleton de La Presse. La Presse, Paris, 30 de setembro de 1844, p. 1-2. Disponível em http://gallica.bnf.fr/ark:/12148/bpt6k429717x.

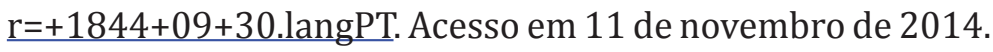


GAUTIER, T. Le Roman de la momie. Paris : Hachette, 1858. Disponível em http://catalogue.bnf.fr/ark:/12148/ cb30490246s. Acesso em 4 de novembro 2014.

. Emaux et camées, avec une iconographie rassemblée et commentée par Madeleine Cottin. Paris : Lettres Modernes Minard, 1968.

Contes et récits fantastiques. Paris : Librairie Générale Française, 1990.

. Un repas au désert de l'Egypte. Disponível em http://www.logoslibrary.eu/document.php. Acesso em 21 de novembro 2014.

GIUSEPPE VERDI ; Sua vida, sua obra. (La vita de Verdi). DVD. Itália, França, Alemanha: RAI \& TRADE, 1982.

ISON, C. Le Tourneur d'. Mariette Pacha ou le rêve égyptien. Paris : Plon, 1999.

LE GOFF, J. História e memória. Trad. Bernardo Leitão [et al.]. Campinas, SP: Editora da Unicamp, 2003.

LOVENJOUL, Ch. Histoire des oeuvres de Théophile Gautier. Tome deuxième. Genève: Slatkine, 1968. (Facsímile da edição de Paris, 1887). Disponível em gallica.bnf.fr/ ark:/12148/bpt6k8840n. Acesso em 05 de novembro 2014.

NAUGRETTE, Fl. Le théâtre romantique; histoire, écriture, mise en scène. Paris : Seuil, 2001. 
POUGIN, A. Verdi ; Histoire anecdoctique de sa vie et de ses oeuvres. Paris: Calmann Lévy, 1886.

Disponível em http//bnf.fr / Bibliothèque nationale de France. Acesso em 31 de agosto 2013.

SAIID, E. Orientalismo; o Oriente como invenção do Ocidente. Trad. Rosaura Eichenberg. Coleção Companhia de Bolso. São Paulo :Companhia das Letras, 2007.

VERDI, G. Aida. Chorus, ballet and orchestra of the National Theatre Brno; Ernst Mäzendorfer. DVD. República Tcheca Brno: Euro Arts \& Video Brokers, 2009.

Sites:

http://www.cairoopera.org/history.php, consultado em 15 de agosto de 2013.

http://www.ophicleide.fr/fr/133250881820376-unetrompette-un-peu-particuliere-.html\#.VHRI 81NeTc, consultado em 25 de novembro de 2014.

1ritiques européens, M. Ernest ébt eur FilippFilippi, de la Perseverza, 



\title{
AESCRITURA DE UM EFÊMERO: ASPECTOS DA RELEITURADA OBRA BAUDELAIRIANA
} EM UNE HISTOIRE DE BLEU, DE JEAN-MICHEL MAULPOIX

\section{SCRIPTURE AN EPHEMERAL: ASPECTSOF READING INTHE WORKBAUDELAIREAN}

\author{
UNE HISTOIRE DE BLEU, \\ JEAN-MICHEL MAULPOIX
}

Erica MILANEZE ${ }^{1}$

\begin{abstract}
RESUMO: No cenário da poesia francesa contemporânea, o lirismo crítico expressa um prolongamento das tendências de recuperação da escrita lírica iniciada nos anos 80 do século XX. Neste contexto, os ensaios e os textos poéticos de Jean-Michel Maulpoix são representativos desta vertente poética, especialmente Une histoire de bleu, onde o poeta exterioriza sua interioridade e efetua uma reflexão sobre seus sentimentos e suas dúvidas, ao mesmo tempo em que questiona a realidade exterior e a linguagem poética. Além
\end{abstract}

\footnotetext{
1 Pós-doutoranda em História e crítica literária e professora colaboradora do Departamento de Teoria Literária, Instituto de Estudos da Linguagem, Universidade Estadual de Campinas, UNICAMP, CEP 13083-859, Campinas, SP, Brasil. Pesquisadora da Fundação de Amparo à Pesquisa do Estado de São Paulo (FAPESP). email: erica.milaneze@gmail.com.
} 
disso, Une histoire de bleu revela uma releitura da obra de Charles Baudelaire em consonância com as formulações críticas de Maulpoix, que se confessa herdeiro do poeta da modernidade. Pretendemos analisar alguns aspectos da releitura efetuada por Jean-Michel Maulpoix em Une histoire de bleu da obra baudelairiana para compreender seu papel nos mecanismo de construção do lirismo crítico no interior do texto e a influência do poeta da modernidade no projeto estético do autor contemporâneo.

PALAVRAS-CHAVE: poesia francesa; poesia contemporânea; lirismo crítico; Jean-Michel Maulpoix; literatura contemporânea

ABSTRACT: In scenario of contemporary French poetry,the critical lyricism expresses a prolongation of the trends of recovery of lyric writing initiated in the 80 s of $\mathrm{XX}$ century. In this context, the trials and the poetic texts of Jean-Michel Maulpoix are representative of this poetic trend, especially Une histoire de bleu, where the poet externalizes his inner self and makes a reflection on their feelings and doubts, while questioning the external reality and poetic language. Furthermore, Une histoire de bleu reveals a reading of the work of Charles Baudelaire in agreement with the critical formulations Maulpoix, which the poet confesses heir of modernity. We intend to analyze some aspects of rereading carried out by Jean-Michel Maulpoix in Une histoire de bleu of Baudelaire's work to understand their role in the construction the critical lyricism in the interior of text and the influence of the poet of modernity in the contemporary design esthetic mechanism author.

KEYWORDS: French poetry; contemporary poetry; critical lyricism; Jean-Michel Maulpoix; contemporary literature

No diversificado e rico cenário da poesia francesa dos últimos trinta anos, os ensaios críticos e as obras poéticas de Jean-Michel Maulpoix (1952) são representativos do lirismo crítico, vertente estética que expressa um prolongamento do movimento de 
renovação lírica que, por volta dos anos 80 do século $\mathrm{XX}$, inicia uma reação à produção das várias vertentes que perfazem as neovanguardas dos anos de 1960 e 1970. Predominantemente voltadas para a experimentação e a abstração, estas neo-vanguardas legam o lirismo para segundo plano a favor da literalidade, sendo a póspoesia no contexto atual uma de suas herdeiras mais proeminentes na medida em que se contrapõe às vertentes neo-líricas, propondo ainda uma "saída" de todos os modelos consagrados pela tradição da poesia.

Neste cenário literário, os trabalhos de Maulpoix revelam sua importância porque trazem uma abordagem teórica mais ampla e aprofundada do complexo conceito de lirismo por meio de sua investigação desde sua origem no Romantismo francês até sua reatualização ao contexto contemporâneo, onde desenvolve o conceito de lirismo crítico. Para Maulpoix (2009, p.09), o lirismo não se reduz nem a ideia simplista de um fluxo verbal exacerbado e de uma efusão dos sentimentos, nem a uma incompatibilidade com a literalidade - opinião compartilhada por críticos como Pinson (1995) e Collot (2006); isto porque, considera o lirismo como um estado poético em que o sujeito sofre ou se beneficia de um "acesso" de linguagem, correspondendo à maneira como o sujeito se coloca no texto poético, ou seja, ao movimento da linguagem dentro do corpo e na voz do sujeito que se transforma em escrita (MAULPOIX, 2000, p.23). No ensaio La poésie comme l'amour (1998), Maulpoix descreve outras formas, além do lirismo crítico, por meio das quais o lirismo pode se manifestar na literatura contemporânea, inclusive no interior das tendências experimentais e literais: lirismo do movimento; do embaralhamento; do prosaico; da precariedade; da alteridade; da voz; da desilusão. Na verdade, o lirismo crítico expressa um outro encaminhamento possível para a produção contemporânea em relação às propostas da pós-poesia, pois defende a persistência da 'poésie malgré tout'. De fato, o lirismo crítico procura preservar a voz e as emoções do sujeito apesar dos riscos de cair no pathos e no sentimentalismo; assim, crítico é o lirismo 
que escava mais que eleva, interroga mais que celebra, "critique, cette écriture qui se retourne anxieusement sur elle-même au lieu de chanter dans l'insouciance. Mais lyrique cependant, puisque les questions qu'elle pose restent indissociables de l'émotion d'un sujet et de la circonstance vécue." (MAULPOIX, 2009, p.21). Quando assume uma postura crítica, o lirismo atua como um articulador entre as emoções do sujeito, a realidade exterior e a linguagem, ao mesmo tempo em que examina, analisa e investiga em uma atitude metapoética sua escrita e o impulso lírico.

Ao longo do processo de reavaliação do lirismo, Maulpoix se detém na investigação da modernidade poética, encontrando na obra de Charles Baudelaire a gênese de um lirismo que se torna crítico, pois se afasta do sentimentalismo, da efusão, do pathos, da inspiração - exacerbados por uma certa vertente romântica - e, ao trazer a consciência crítica para o ato criador, acaba por transformar o lirismo em um lugar crítico (MAULPOIX, 2000, p. 89). É interessante citar as considerações de André Gide, em sua Anthologie de la poésie française (1949), sobre a contribuição de Baudelaire para a renovação das concepções poéticas promovidas pela modernidade, utilizadas inclusive por Maulpoix para reforçar seu argumento, porque advém de um crítico e romancista que presencia de modo mais imediato os efeitos que as mudanças estéticas do final do século XIX determinam no início do século XX:

L'on ne s'aperçut pas aussitôt de l'extraordinaire nouveauté qu'apporta Baudelaire dans le champ de la poésie; on ne consentit à voir dans Les Fleurs du mal que la nouveauté des sujets traités (ce qui n'avait que peut d'importance); mais c'était une révolution sans précédant que de ne plus s'abandonne aux flux lyrique, de résister à la facilité de 'inspiration', au laisser-aller rhétorique, à l'entraînement des mots, des images et des conventions surannées; que de traiter la Muse en rétive, qu'il faut soumettre au lieu de s'en remettre à elle, esprit et sens critique liés, bref: que d'inviter l'art à maîtriser la poésie (GIDE, 1949 apud MAULPOIX, 2000, p. 88). 
Dentre as obras poéticas de Jean-Michel Maulpoix, Une histoire de bleu, publicada em 1992, corresponde a seu primeiro texto poético no âmbito do lirismo crítico. Nela os versos cedem lugar a uma prosa que se coloca nas fronteiras com a poesia, ao mesmo tempo em que questiona a escrita poética e o ímpeto lírico. Com efeito, o poeta exterioriza sua interioridade e efetua uma reflexão acerca de seus sentimentos, dúvidas e crenças, enquanto interroga a realidade exterior e a linguagem poética por meio do motivo da cor azul, que adquire nas diversas pequenas prosas que compõem a obra um sentido polissêmico - é a cor do céu, do mar, do amor, da morte, da melancolia, do olhar, do ideal, da religiosidade, etc. -, construindo uma rede complexa de reflexões e questionamentos, que lhe permite dar conta de suas experiências e emoções depreendidas pelo contato com o mundo exterior pelo ato da escrita. Matéria fluida, visível e a um só tempo invisível, que se expande pelo espaço exterior, impregnando a interioridade dos seres e das coisas, o azul ou "bleu" se transforma nas emoções que determinam o estado poético, mistura-se ao corpo, estimula a voz a exteriorizar o canto e, ainda, desencadeia uma disposição interior no sujeito que lhe permite perceber suas mais tênues manifestações na realidade exterior. $\mathrm{O}$ azul envolve, então, tanto a paisagem quanto o ser humano, reunindo a vida e a escrita na medida em que é a manifestação da poesia na matéria e nos sentimentos:

Ce n'est pas, à vrai dire, une couleur. Plutôt une tonalité, un climat, une résonance spéciale de l'air. Un empilement de clarté, une teinte qui naît du vide ajouté au vide, aussi changeante et transparente dans la tête de l'homme que dans les cieux.

L'air que nous respirons, l'apparence de vide sur laquelle remuent nos figures, l'espace que nous traversons n'est rien d'autre que ce bleu terrestre, invisible tant il est proche et fait corps avec nous, habillant nos gestes et nos voix. Présent jusque dans la chambre, tous volets tires et toutes lampes éteintes, insensible vêtement de notre vie. (MAULPOIX, 2005b, p. 67). 
Desta forma, o azul pode ser considerado, conforme a definição de Collot (1997), uma matéria-emoção que corresponde ao próprio lirismo tal qual o define Maulpoix.

Analisando alguns aspectos da releitura de Jean-Michel Maulpoix da obra baudelariana, depreendemos que Une histoire de bleu se vincula à escrita de um efêmero em que a linguagem lírica e crítica se apóia no aspecto transitório das vivências do poeta que lança seu olhar para o universo exterior com o intuito de construir uma escrita que dê conta de sua interação com a realidade contemporânea. Situado no contexto do final do século $\mathrm{XX}$, o poeta exterioriza a melancolia causada pela consciência da impossibilidade definitiva de satisfazer seu desejo de atingir o Ideal - ou "L'Azur" como o denomina Mallarmé em seu famoso poema - e de sua condição de criatura finita irremediavelmente presa nos limites da realidade terrena: "L'azur est lettre morte, l'horizon est indéchiffrable. On se demande comment rester debout dans ce paquet de chair. La terre n'est pas si difficile: elle veut bien de nos os. Mais le ciel bleu dédaigne notre paleur" (MAULPOIX, 2000, p. 63), como ressalta em Une histoire de bleu. Maulpoix (2006, s.p.) se confessa herdeiro da modernidade a partir de "L'Albatroz" baudelairiano, claudicando entre sua época e a tentação de uma retirada intemporal na natureza. Tal postura diante da transcendência e da realidade contingente percorre as obras do autor e revela que a reinterpretação da modernidade conforme a define Baudelaire, em $O$ Pintor da vida moderna (1863), fornece o suporte para a constituição de um texto lírico e crítico, em que o lirismo se coloca em uma posição intermediária de maneira a articular a subjetividade, o mundo exterior e a linguagem em uma relação estreita e complexa. Assim, o poeta permanece no espaço entre o céu e a terra, entre o "ici" e o "là-bas", espaço "entre-deux" ou intermediário que compõe o limite de seu horizonte - espacialidade preenchida pelo "bleu" em Une histoire de bleu - e, por conseguinte, a paisagem que visualiza e o envolve, onde transcorrem suas percepções e sensações. A paisagem romântica se caracteriza por um horizonte ilimitado que 
se abre para o infinito, o qual o poeta anseia por ultrapassar para entrever a divindade que, entretanto, não se deixa revelar. Contudo, para os românticos a metáfora do horizonte exprime de modo radical e dramático o recuo de Deus em uma profundeza inacessível (COLLOT, 1988, p. 53). Com a modernidade, o horizonte adquire uma conotação negativa, uma vez que oferece ao olhar a imagem de um infinito cósmico esvaziado da presença divina e de dimensões desproporcionais diante da finitude humana. 0 horizonte se apresenta, então, como uma abertura vazia que se fecha sobre a paisagem, juntamente com a parcela do céu e da terra que lhe é contígua (COLLOT, 1988, p. 73-6). Tal a imagem do horizonte que permanece até os dias atuais, da qual Maulpoix se nutre em Une histoire de bleu.

0 poeta francês Jean-Claude Pinson, no ensaio Habiter en poète (1995) lembra que a reabilitação da realidade contingente é um fenômeno que se desenvolve de modo mais específico na literatura moderna, principalmente na poesia, que a torna um referente privilegiado. Lembrando as afirmações de Northrop Frye em Anatomia da crítica (1957), Pinson (1995, p.97) comenta que a produção moderna "voit son centre de gravité se déplacer peu à peu du haut vers le bas, de l'idéal vers le réel, du nobre vers le grotesque, du merveilleux vers le trivial.". Quando se acompanha, ainda conforme Pinson (1995, p.97), esta evolução ao longo do tempo, constata-se que pertence também "à l'échelle plus resserrée de la poésie contemporaine", como aponta, inclusive, o poeta Philippe Jaccottet (1992, p. 268).

Ao efetuar a releitura da definição baudelairiana, "a modernidade é o transitório, o fugaz, o contingente, a metade da arte cuja metade restante é eterna e imutável" (BAUDELAIRE, 2010, p.35). Maulpoix se detém na relação que o aspecto transitório estabelece com o ser humano inserido em um determinado intervalo temporal, ou seja, o transitório é a condição do homem que "naît, qui souffre et qui meurt. Avec ses affections, ses vices, tribut payé au temps et à autrui. Les avatars singuliers d'une disparition, rien de plus." 
(MAULPOIX, 1998, p. 69). Interessa para Maulpoix compreender a transitoriedade como uma condição individual e, portanto, variável para cada ser humano dentro de um único ou em diferentes contextos sociais, históricos e culturais. De acordo com este ponto de vista, perfaz o período de duração da vida de cada homem com suas experiências, percepções e sensações desenvolvidas por meio do contato com os outros seres humanos e com a realidade contingente desde o seu nascimento até a sua morte. É nesta direção que incide a reflexão de Maulpoix acerca do que venha a ser o contemporâneo:

Je suis, comme quiconque, [...] le contemporain des gens que je croise et de ceux avec qui je partage mon temps, de ceux à qui je donne de mon temps, de ceux avec qui je prends ou je perds mon temps. [...] Je suis le contemporain de mes sensations, mes désirs, mes chimères, mes oublis, mes pensées. Je suis le contemporain de tout ce qui insiste en moi. Je suis le contemporain du corps de ma mère dont après un demi siècle d'efforts j'ai toujours bien du mal à (me) sortir. Je suis le contemporain de ceux que j'aime, parce que ceux que j'aime m'offrent du temps et des raisons de vivre. Je suis le contemporain de mon transitoire. D'un enfant qui naît et d'un homme qui meurt (MAULPOIX, 2005a, p. 52-4).

Neste intercâmbio entre a subjetividade e a alteridade, Maulpoix se considera, junto com seus semelhantes, contemporâneo de um contexto mais amplo que abrange toda sua época, esta também extremamente contingente, da qual nenhum ser humano pode escapar: "Je suis donc le contemporain de George Bush et de Ben Laden, de Star Academy et d'Yves Bonnefoy, de BHL et du DVD, du téléphone portable, d'Internet et du Mac Do, etc." (MAULPOIX, 2005a, p. 52). Ora, ao tomar o transitório do ponto de vista do sujeito, o autor aproxima o conceito de modernidade formulado por Baudelaire da maneira como entende o contemporâneo, pois a vida humana se concretiza em uma temporalidade transitória em qualquer momento histórico ou social. Desta forma, o poeta 
como qualquer outro ser humano com quem compartilha sua contemporaneidade participa do caráter efêmero da vida que se insere, por sua vez, em um presente também contingente. Em Une histoire de bleu, o poeta denota um sentimento de tristeza frente à consciência da transitoriedade da vida e da realidade exterior, relacionando-a também com a precariedade das palavras em transmitir as vivências em sua amplitude e inteireza diante da finitude: "Nous sommes ici pour peu de temps: quelques mots, quelques phrases, si peu sous les étoiles, rien que cela, parmi tout le reste." (MAULPOIX, 2005b, p. 39).

Neste sentido, o transitório observado por Baudelaire como uma das faces da modernidade será explorado por Maulpoix em diversas acepções a fim de construir os laços entre a subjetividade e a alteridade, articulação que caracteriza um dos aspectos do lirismo crítico, que corresponde também a "une écriture lyrique tendue par et vers l'altérité (épreuve de l'altérité en soi et au-dehors de soi) et qui met en examen la poussée lyrique» (MAULPOIX, 2001, s.p.). Esta escrita lírica apresenta, a meu ver, um dinamismo que é responsável pela transição da interioridade à realidade exterior, que compreende tanto as coisas quanto os outros seres humanos, sendo um instrumento articulatório que estabelece uma continua circulação entre o mundo interior e o exterior.

$\mathrm{Na}$ esteira baudelairiana, o autor contemporâneo "prend du transitoire son parti" para elaborar a partir dele uma escrita poética, em que o lirismo se torna o esforço articulatório que faz de uma vida uma voz e que busca uma possível coincidência entre o movimento da pluma e o passo do destino (MAULPOIX, 2000, p. 89). Converter as experiências vivenciadas ao longo da vida em uma voz e, consequentemente, em uma escrita que consiga apreender as sensações e as percepções na efemeridade de seu presente e da presença, tal o anseio que Maulpoix tenta materializar nas pequenas prosas de Une histoire de bleu. Unindo a vida à escrita, o poeta contemporâneo busca uma forma possível de se adaptar à realidade na qual se insere, ou seja, de "habitar" poeticamente 
a vida e o mundo, postura que caracteriza toda uma vertente do lirismo contemporâneo que deseja dizer a vida e o mundo por meio da subjetividade, em oposição às tendências experimentais neo-vanguardistas e à pós-poesia que desenvolvem uma poética do evento ao se colocarem à escuta do que a vida diz a partir do trabalho com a linguagem (GAME, 2001, s.d.).

Para tanto, Maulpoix recupera o transitório no sentido do ato de transitar, do deslocamento de um lugar para outro no espaço, o que implica um sujeito em um constante movimento em sintonia com as transformações ininterruptas da realidade que o cerca, onde as mudanças estão cada vez mais aceleradas e intensas desde a modernidade até a sociedade midiática e tecnológica contemporânea. Se, como lembra Maulpoix (1998, p. 72), o caminhante solitário que foi Rousseau andava pelos bosques em busca de elevação por meio da comunhão com a natureza no final do século XVIII, o "rôdeur" baudelairiano perambula e não mais caminha pelos espaços naturais na segunda metade do século XIX, mas pela grande cidade em intenso processo de transformação, fragmentado entre o spleen e o ideal, tendo-se, portanto, dois diferentes tipos de deslocamento. 0 trajeto lírico do solitário»rôdeur», segundo a leitura de Maulpoix (2005a, p. 176), é uma atitude dolorosa em busca de extrair a beleza do mal, pois o poeta espera que, ao agravar os aspectos negativos da realidade urbana e dos efeitos destes na vida humana, possa se elevar apesar de todos os obstáculos. Se existe algum ímpeto vertical para o ideal na obra baudelairiana, este se manifesta apenas na solidão do quarto “'à une heure du matin', lorsque l'artiste retranché appelle à lui la grâce de quelques beaux vers. Le reste du temps, la verticalité est barrée, étouffée par un lourd couvercle" (MAULPOIX, 2000, p. 90). Já o poeta contemporâneo, tal qual o concebe Maulpoix, tende a se situar tanto na solidão de seu quarto quanto na profusão das ruas da cidade, movimentando-se ou transitando de um espaço para outro: 
Mobile, plutôt que penché sur le vierge papier [...] C'est [...] une abeille qui va et vient sans cesse de la route à la chambre et qui rapporte son butin dans 'la ruche de l'invisible'. Et c'est parce qu'il est lui-même une espèce d'oeil double, partagé, divisé de l'intérieur, qu'il ne peut trouver d'apaisement que dans le mouvement. (MAULPOIX, 2009, p. 35, grifo nosso).

O poeta lírico-crítico se situa em uma posição intermediária, em um "entre-deux", como o próprio lirismo crítico, mantendo-se em um frágil equilíbrio devido à intensa movimentação entre a interioridade e a realidade exterior, em um deslocamento constante "d'aller et de venir" entre o quarto e a rua, da escrita para a vida e vice-versa: "[...] sans cesser, il [le lyrisme/le poète] continue d'aller et de venir entre la chambre et la rue, la page et les vivants" (MAULPOIX, 2009, p.32).

Com efeito, em Une histoire de bleu, o poeta realiza um itinerário de seu quarto para a rua, especialmente em direção aos espaços à beira-mar, em um movimento de idas e vindas, atento aos elementos materiais e aos seus semelhantes, aos quais observa para desenvolver tanto uma experiência pessoal quanto se identificar com as experiências da alteridade a fim de estabelecer um íntimo contato com a exterioridade. Em uma das prosas, aparece dentro de um barquinho, envolvido pela imensidão do mar e pelo brilho das estrelas; porém, a escuridão da noite o impede de visualizar a paisagem que se expande até a linha do horizonte. Esta obscuridade desperta no poeta sentimentos contraditórios, o desejo de uma experiência metafísica com a divindade e a angústia diante da consciência da impossibilidade em satisfazer tal anseio, uma vez que dos deuses resta apenas um vazio. Um conforto, no entanto, advém ao acender um cigarro, cuja luz ilumina o espaço à semelhança de uma estrela, dando-lhe a sensação de existir, de "habitar" o mundo, ou seja, de fazer parte, ser uma pequena parcela da vida que se desenvolve e se movimenta incessantemente no espaço ao seu redor, na alteridade exterior: «J'aime allumer une 
cigarette au milieu de la mer. C'est un minuscule point rouge sur le bleu. Un point d'incandescence, de grésillement et de chaleur. Il signifie que j'existe: je suis une graine, une pépite d'homme, une parcelle d'âme en larmes [...]» (MAULPOIX, 2005b, p. 103). Por outro lado, o poeta lança seu olhar atentamente para as atitudes, as falas, os gestos cotidianos, enfim, para a movimentação dos outros seres humanos, eles também às voltas com sua contingência:

Ils se déplacent. Ils songent à se placer. [...] Promptement, ils s'habillent, se dévêtent, et se rhabillent encore devant le miroirs. Cela, semble-t-il, les occupent. [...] Vivants, ils vont les mains devant. [...] Ils racontent tout haut leurs soucis, expliquent leurs misère, découpent des images, inventent des histoires, chantent à tue-tête et se trémoussent sur des musiques. Ils fouillent parfois dans leur mémoire pour y chercher un mots qui se puisse murmurer à l'oreille d'une femme [...] (MAULPOIX, 2005b, p. 44-5).

Ao observar as vivências da alteridade, a voz poética acaba por se projetar em suas experiências de maneira que o outro se torna um prolongamento ou uma parte de si mesma. Para exteriorizar seus sentimentos, suas emoções e suas queixas, a voz lírica busca uma orelha, chamando para o discurso a presença de um "tu" que pode ser Deus, o ser amado, um animal, um objeto inanimado ou até uma pessoa qualquer. Entretanto, esta alteridade que corresponde ao "tu" pode expressar também uma parte da própria voz lírica - o que remete a uma fragmentação da subjetividade -, e ainda, a um "tu" que se exterioriza por meio da primeira pessoa do singular e que, assim, assume a autorreflexidade lírica. O lirismo crítico constitui o que Maulpoix denomina a quarta pessoa do singular, uma pessoa potencial e contraditória que trabalha em conjunto todas as instâncias discursivas, mas que não corresponde "ni le 'je' biographique de l'individu, ni le 'tu' dramatique du dialogue, ni le 'il' épique ou romanesque" (MAULPOIX, 1998, p.36). Todavia, o sujeito lírico, na verdade, não existe, conforme Maulpoix (1998, p.32), 
porque ocupa o intervalo invisível e móvel entre o "je" o "moi", isto é, estabelece-se no intervalo e no deslocamento entre o indivíduo e o conteúdo de sua vida afetiva, entre o que a criação deseja e seu conteúdo. Desta forma, a instância poética de Une histoire de bleu se fragmenta nas várias pessoas do discurso, il ( $s$ ), je, on, nous, tu e vous, a fim de proporcionar uma abertura da interioridade para as diversificadas transições da alteridade na realidade contingente, vivenciando suas percepções, sensações, tristezas, dificuldades, etc. como se fossem experimentadas por si mesma.

0 autor contemporâneo caracteriza o poeta como um ser que caminha sobre a terra, à semelhança do "flâneur" baudelairiano, em uma errância em que importa mais o movimento de seguir sempre adiante apenas guiado pelo movimento ou pela visualização de algum detalhe na paisagem, uma pessoa, um objeto ou um lugar particular, que lhe desperta uma percepção mais aprofundada da realidade, como no itinerário do poeta em Ne cherchez plus mon coeur (1986):

Il lui arrive de marcher des heures à travers la ville, improvisant l'itinéraire au gré de la perspective, du tumulte, des coloris, ou pour la seule inclination des passants qui déambulent par là plus vifs et plus légers. Cette marche le délivre. Ce n'est plus lui qui va ni qui décide, mais l'oeil et le pas des silhouettes qu'il accompagne. Pour une mèche de cheveux, il change de trottoir. Quelques boutiques le retiennent: l'une vend des couteaux au pied de la montagne Saint-Geneviève, une autre des vieux livres symbolistes parmi des foulards et des Tour Eiffel au bord de la Seine. À l'angle d'une rue, son histoire termine, le ciel s'entrouve, c'est presque la mer. C'est un marché parfois, avec des poissons et des fruits, des cris et des parfums mêlés comme en province. Parfois, c'est une école à l'heure de la récréation: on s'arrête, on observe, on écoute, on s'accroche, on regarde toujours à travers des grilles (MAULPOIX, 2012, p.12).

Nos textos de Maulpoix, o poeta se identifica e se projeta no 
homem comum - com o qual comunga o caráter efêmero da vida e o contexto sócio-cultural -, que todos os dias espera pelo transporte que o conduz para suas ocupações, começando e recomeçando suas experiências que são sempre as mesmas sendo também outras: "[...] celui qui attend l'autobus ou le train de banlieue, les ailes repliées sous l'imperméable, à la même heure toujours sur le même quai, prêt à s'embarquer vers le premier jour de sa propre vie." (MAULPOIX, 2005b, p.51). Este homem, que seria um alterego do próprio poeta, como o albatroz do soneto baudelairiano, apresenta-se em uma postura de recolhimento com os braços/ asas dobrados próximos ao corpo, melancólico devido ao apecto repetitivo de seu cotidiano. No entanto, caracteriza ainda o ser humano mergulhado na contingência como alguém sem traços definidos, sem uma identidade definida, como se todos os homens se assemelhassem e comungassem a mesma aparência física, os gestos, os sentimentos, as experiências, etc., sendo somente "fantoches de açúcar" que perdem a singularidade de sua identidade ao se submeterem e se deixarem manipular pelos mecanismos da sociedade contemporânea: "De ses semblables, il mélange les traits, pour qu'on ne puisse les reconaître et qu'ils se sentent ainsi moins seuls, moins prisonniers de leur figure et de leur corps périssable [...]. il ne donne pas de nom à ces patins de sucre [...]" (MAULPOIX, 2005b, p.51). Na medida em que se projeta nas vivências dos outros também compartilha essa despersonalização do ser humano nas grandes cidades, despersonalização que se inicia na obra baudelairiana onde, conforme a leitura de Maulpoix (2000, p. 94), as diversas personagens criadas pelo poeta em Spleen de Paris, os pobres, a pequena velha, o louco, o cachorro, Madame Bistori, o vidraceiro, etc. são manequins que vestem e encarnam os vícios e as dores causadas por sua imersão no real, ou seja, na Paris da segunda metade do século XIX, que se define por seus lugares malditos que, entretanto, exercem um intenso fascínio sobre o poeta. Como lembra Maulpoix ao recuperar o poema "Les petites vieilles" de Les fleurs du mal e as errâncias do poeta em Spleen de 
Paris, "dans les rues de la ville: c'est bien là, en effet, qu'il rôde, qu'il va, qu'il court, qu'il cherche, celui que Baudelaire appelle 'le peintre de la vie moderne', lancé dans le 'grand désert des hommes' à la poursuite de 'ce quelque chose qu'on nous permettra d'appeler la modernité"' (MAULPOIX, 2002, p. 73). No entanto, a cidade por onde o "flâneur" transitava no passado, não permite mais que o poeta se lance na aventura de extrair o eterno do transitório, pois ao se transformar em uma metrópole no contexto contemporâneo, absorve os seres humanos e a si mesma, criando uma ruptura cada vez mais acentuada entre a subjetividade e a alteridade:

Or, ce schéma baudelairien a perdu de sa force, en même temps que s'épuisait la modernité et que la ville elle-même se trouvait absorbée et défaite en mégapole, réseau, banlieues: la combinatoire et l'interconnexion y prenant le pas sur la dialectique, la saturation des signaux et la bousculade accélérée des corps y occultant la lisibilité des signes et des figures. Dans l'horizon contemporain, le bavardage du village global recouvre les bruits et les voix de la ville. Indéfiniment distendue, elle ne donne plus l'échelle ni le plan de l'humaine condition. [...] Dans les rues de la ville, il y a les excréments canins. La passante d'aujourd'hui téléphone en marchant. Elle porte sur les oreilles un walkman. La passante de naguère est devenue touriste. La rue appartient aux 'rollerbladers': à ceux qui circulent et qui glissent, et non à ceux qui cherche ce mystérieux quelque chose qu'on appelle 'la modernité'. Ceux qui roulent sur leurs patins ou sur leur trotinette ne cherchent rien: ils jouissent d'eux-mêmes. Voici que la rue s'est changée en salle de jeux ou terrain de sport (MAULPOIX, 2002, p.77-9).

Neste contexto, Maulpoix se indaga, inspirado em Baudelaire, «que cherche-t-il [le poète]?», encontrando a resposta ao analisar a deambulação do poeta no texto lírico-crítico Les ruines de Paris (1977), de Jacques Redá:

À l'oeil du baguenaudeur postmoderne n'apparaissent plus 
de créatures ni de lieux exemplaires, investis d'une valeur morale, susceptibles de se coordonner pour former des figures lisibles et emblématiques. [...] Les grandes identités symboliques qui pour Baudelaire s'appelaient le pauvre, la prostituée, l'enfant, la vieille, ne sont plus sous la plume d'aujourd'hui que des silhouettes incertaines de gens qui font la queue devant une boulangerie [...]. La grande ville est creuse et vacante. Tout a déjà eu lieu: le monde est pleine de lieux communs (MAULPOIX, 2009, 191-2).

Inserido no espaço terreno contingente, seu único horizonte possível, o homem contemporâneo passa a ser um viajante sempre na espera de um acontecimento que venha quebrar a rotina cotidiana e que represente a aventura de uma outra ou uma nova partida, isto é, de uma experiência renovada. Com efeito, em Une histoire de bleu, o poeta acaba por se transformar em um viajante que descreve um deslocamento constante de idas e vindas, de sua casa para o mundo exterior, sempre no aguardo ou na esperança de vislumbrar a manifestação de um instante poético: "De quais de gares et d'aéroports, de valises faites et défaites, de piles de chemises ou de livres, et d'encre noire qui vire au bleu" (MAULPOIX, 2005b, p. 108). Assim, seu trajeto lírico corresponde a um ir e vir, das partidas para o mundo ao ansioso retorno para o aconchego de sua casa junto à amada e à intimidade de seu quarto - "Mais toujours je reviens vers elle, vers sa maison odorante et propre où il y a beaucoup de place pour mes après-midi de pages blanches" (MAULPOIX, 2005b, p. 109) -, em detrimento da multiplicidade de trajetórias do lirismo apontadas por Maulpoix (2005a, p.178-9) na obra baudelairiana: vertical, horizontal, em linhas quebradas, oblíquas, etc.. Em Une histoire de bleu, o quarto da casa do poeta denota, então, o lugar de recolhimento em que se volta para sua interioridade e para a escrita poética, em oposição aos impessoais quartos de hotel cujos corredores dão sempre para outros quartos com as portas fechadas, onde somente lhe resta abdicar ao prazer da escrita: “je ne m'y installe guère. Couloirs plutôt, ils donnent sur des chambres. Je cogne aux portes et vais de défaits en abdications. Les 
jours de mes chimères sont comptés» (MAULPOIX, 2005b, p. 108). 0 poeta contemporâneo é o poeta das estações de trem ou de metrô e dos aeroportos, que só pode temporariamente experimentar a sensação de atingir o céu ao viajar de avião, retornando sempre para seu ponto de partida terreno, onde mesmo as viagens de trem não lhe permitem lançar-se além do horizonte. Desta forma, as viagens não permitem ao poeta lírico-crítico uma evasão em que possa ultrapassar seu horizonte rumo ao infinito, pois correspondem apenas a um trânsito pelo espaço terreno contingente que ressalta ainda mais sua condição finita.

Como também assinala Maulpoix (2000, p.89), ao refletir acerca do transitório a partir do pensamento baudelairiano, cabe ao homem ser um lugar de passagem tanto quanto um passageiro. Enquanto passageiro, o poeta se deixa levar pelo movimento da vida cotidiana tendo como espelho a alteridade, porém, pode viajar imóvel diante da página em branco, seja para um passado perdido na infância, seja por meio da tentativa de satisfazer seu desejo pelo infinito. Contudo, como um "lugar de passagem" se coloca a disposição do efêmero na procura de uma apreensão mais primária, imediata e profunda da realidade pela percepção sensorial, registrada pela escrita. De fato, seu corpo permanece sempre alerta, estimulado pelos sentidos que captam, por exemplo, o lento movimento dos barcos amarrados no porto ao anoitecer, o céu que readquire uma tonalidade azulada após a tempestade que cai sobre a cidade, a alegria sensual de homens e mulheres que se encontram no fim da tarde nos bares para o happy-our, o soar do sino da igreja badalando oito horas, o prazer em acender um cigarro dentro de um barquinho em alto-mar ou em ouvir o som das ondas que se quebram na praia atrás das venezianas de um quarto, ou ainda, relembrar a voz da mãe soletrando o alfabeto na infância quando ouve o barulho do mar. São instantes frágeis e efêmeros registrados pela escrita, que originada a partir de um estado poético despertado pela percepção, capta apenas parcelas da realidade e as transforma em fugazes instantes de poesia, como ao descrever a 
beleza que se depreende da observação de um jardim em uma tarde de domingo: "Des jardins superflus poussent plus haut vers le large, odorants de menthes, de myosotis et d'impatientes. Une rumeur de lilas dégringole vers la mer quand, sur les balcons de bois peints, le coeur des marins s'éclabousse» (MAULPOIX, 2005b, p.34).

0 poeta procura fazer com que o ato de escrita ocorra o mais próximo possível do momento de sua percepção, de modo que por seu corpo ressoe os frágeis acontecimentos da realidade exterior, convertendo-os em escrita poética. Notamos este processo, por exemplo, em uma das pequenas prosas de Une histoire de bleu, pois enquanto a chuva cai, o poeta vai acompanhando lentamente as sensações e emoções que lhe são despertadas pela sonoridade da água, que produz uma linguagem que corresponde ao estado poético, ou seja, ao lirismo:

Tard en automne, lorsque la pluie tombe à petit bruit, il me plaît de croire entendre le ciel pleurer. Écrire ajoute alors ses larmes compliquées à la transparente coulée qui fait tinter le toit d'ardoise et le zinc du chéneau. [...] À cette heure et en cette saison, l'on ne brusque pas le langage, on s'y abandonne, sûr que pour une fois la justesse est en un tel acquiescement au murmure de la pluie et à l'obscurité de la fenêtre (MAULPOIX, 2000b, p. 110).

Como forma de apreender esta temporalidade efêmera, em que os limites entre o passado, o presente e o futuro são muito tênues, o poeta carrega consigo um caderninho de notas, nomeado no texto "Carnet d'un éphémère" em Une histoire de bleu, onde vai anotando ou rabiscando estes momentos fugazes recolhidos do contato com a alteridade, tanto a alteridade humana quanto a alteridade urbana ou natural, ou as reflexões e os questionamentos relativos à escrita poética. 0 caderninho de notas fornece ao poeta um instrumento que lhe permite registrar os momentos efêmeros que são despertados por suas atentas observações da realidade contingente, porque possui a vantagem de acompanhá-lo em suas idas e vindas, em seus deslocamentos da rua para a solidão do quarto, das viagens 
para o aconchego do lar e vice-versa; portanto, o caderninho de notas atua como uma extensão do poeta e por isto participa de sua transitoriedade entre o interior e o exterior, a reflexão crítica e a revelação poética. Tende ainda a dar conta do anseio de Maulpoix de transformar as experiências da vida, sejam os momentos especiais em que consegue vislumbrar o efêmero, seja em suas caminhadas em busca de uma aproximação com seus semelhantes ou até com a divindade, em uma escrita poética durante seu transitar pela realidade contingente, por isto, o poeta afirma:

\begin{abstract}
À vrai dire, je n'écrit pas, je note, furieusement. Un carnet à petits carreaux, sur une borne, au carrefour, près du panneau de l'abribus. Là où s'affiche la fille en soutiengorge noir, au regard de madone. Là où le Christ de pierre grise penchait naguère la tête vers les vieillards. Genoux pliés, je griffonne en faute. Marchant dans la lumière des feux et des enseignes, je me sauve, je me révérbère [...]. Parmi tous ceux qui passent et dont le coeur cogne tout prés. (MAULPOIX, 2005b, p. 106).
\end{abstract}

É interessante salientar que o registro rápido das percepções, das sensações, das descobertas, das reflexões e dos questionamentos acaba por ser o ponto de partida para a escrita de outras obras lírico-críticas de Maulpoix que se relacionam inclusive com sua experiência pessoal, como sua viagem para a China que dá origem a obra em forma de um pseudo-diário Chute de pluies fines (2002), sendo que algumas páginas do caderno de anotações manuscrito resultante desta viagem podem ser vistas no website do escritor, ou ainda, L'Amérique n'existe pas (2014), que corresponde a um caderno de viagem relativo a sua estadia em Los Angeles, nos Estados Unidos.

No entanto, a fugacidade das experiências desenvolvidas com a alteridade mostra para o poeta a fragilidade da vida humana, que caminha passo a passo para a finitude desde o nascimento até a morte, bem como para a irremediável destruição do ser humano e também de suas construções. Como consequência o poeta registra "as diversas formas de morrer" em Une histoire de bleu, onde 
diferentes imagens da morte e de mortos invadem as pequenas prosas: cadáveres de afogados no fundo do mar, uma adolescente em seu leito funerário com um buquê de lilazes entre os seios, velhas caquéticas e carros funerários, os cabelos brancos e as rugas que vão deixando rastros no rosto, a cidade solitária em ruínas, os amores desfeitos, etc. Estas imagens, entretanto, são apresentadas com um tom ao mesmo tempo melancólico e doce, pois o autor não deseja extrair a beleza da morte a fim de atingir um sublime - como o faz Baudelaire, por exemplo, no poema «Une Charogne», mas mostrar a efêmeridade da própria morte:

Une coeur de verre plié. Un tas de bois devant la porte. Un bouquet de lilas entre les seins de la petite morte. Un trait de plume au bas de la page dont continue de s'écouler, longtemps après, l'encre invisible. Une chambre sans meuble, où s'allonguer un soir à même le sol dans un merveilleux corps sans apparence ni nudité (MAULPOIX, 2005b, p. 121).

Por isto, o poeta adverte que «bientôt ne subsistera de la vie passée que bouffissure. De l'amour berloques, les tirelires brisées et les papiers froissés. Il ne restera du coquelicot et du bleuet que la tumeur. Rien qu'une histoire décomposée, dans ses grands haillons blancs et noirs» (MAULPOIX, 2005b, p. 117). Histórias que não podem ser plenamente recompostas porque delas permanecem somente alguns restos, algumas parcelas e alguns fragmentos como a escrita do poeta que tem consciência de sua efemeridade, mas que encontra no seio da finitude o sentido da vida e da escrita: «La mort est en nous l'idée la plus belle, l'idée mère, l'idée douce et sans bornes, la seule idée point trop folle pour laquelle on puisse avoir encore le goût de vivre» (MAULPOIX, 2005b, p. 121). Como o presente sempre se converte instantaneamente em passado, a escrita do poeta se mantém sempre no frágil intervalo entre o que já passou e o que ainda não é, estando, portanto, às voltas com a tentativa de evocar a perda, construir sua escrita com o que resta 
como forma reatar na página em branco os laços que a realidade desfaz.

Enfim, por meio de um intenso processo de releitura da obra baudelairiana, Jean-Michel Maulpoix constrói em Une histoire de bleu a escrita de um efêmero, escrita lírico-crítica que lhe permite articular a subjetividade, a realidade e a linguagem, traçando um rumo para a poesia francesa contemporânea que se diferencia da experimentação desenvolvida pela pós-poesia, que se opõe ao lirismo em seu esforço por romper com a tradição e os modelos perpetuados pela tradição da poesia.

\section{Agradecimento}

Agradeço à Fundação de Amparo à Pesquisa do Estado de São Paulo (FAPESP) pelo financiamento da pesquisa, da qual este artigo faz parte.

\section{REFERÊNCIAS BIBLIOGRÁFICAS}

BAUDELAIRE, C. Les fleurs du mal. Paris: Gallimard, 1991.

O Pintor da vida moderna. Belo Horizonte: Autêntica Editora, 2010.

COLLOT, M. COLLOT, M. Dossier - Lyrisme et Littéralité, 2009. Disponível em <http://periodicalrs.narr.de/index. php/lendemains/.../157>. Acesso em 05/06/2012.

La matière-émotion. Paris: PUF, 1997.

. L'horizon fabuleux. v.I. Paris: José Corti, 1988.

FRYE, N. Anathomie de la critique. Paris: Gallimard, 1977. 
GAME, J. Actualité du moderne. Magazine Littéraire. Paris, n. 396, mars, 2001.

JACCOTTET, P. L'Improbable. Paris: Mercure de France, 1992.

MAULPOIX, J. M. Adieux au poème. Paris: José Corti, 2005 a.

. Chutes de pluie fine. Paris: Mercure de France, 2002.

. Du Lyrisme. Paris: José Corti, 2000.

. Entretien avec Jean-Michel Maulpoix par Laurence Liban. L'Express. Paris, 2006.

- Introduction à une poétique du texte offert Apostilles. 2001. Disponível em <http://www.maulpoix. net $>$. Acesso em 12/07/2010.

. La poésie comme l'amour. Essai sur la relation lyrique. Paris: Mercure de France, 1998.

. L’Amérique n'existe pas. Paris: Le Nouveau Recueil, 2014.

. Le poète perplexe. Paris: José Corti, 2002.

. Ne cherchez plus mon coeur. Paris: Publiepapier, 2012.

. Une histoire de bleu suivi de L'instinct de ciel. Paris: Gallimard, 2005b.

. Pour un lyrisme critique. Paris: José Corti, 2009. 
PINSON, J.C. Habiter en poète. Seyssel: Champ Vallon, 1995.

RÉDA, J. Les ruines de Paris. Paris: Gallimard, 1993. 



\title{
POESIA IMPRESSIONISTA NO SIMBOLISMO BRASILEIRO: MARANHÃO SOBRINHO, PEDRO KILKERRY E ERNANI ROSAS
}

\author{
Jairo Nogueira LUNA
}

RESUMO: Neste artigo buscaremos demonstrar como o Simbolismo brasileiro guarda interessantes relações com a escola Impressionista de pintura e de como essas relações impregnaram o nosso Simbolismo de exemplos de poemas com fortes características Impressionistas. Para tal demonstração, nos utilizaremos de poemas de Maranhão Sobrinho, Pedro Kilkerry e Ernani Rosas, uma vez que os três poetas estão entre os que souberam utilizar a questão da percepção da luz para composição dos cenários imagéticos de seus poemas. Deste modo, acreditamos poder apresentar um texto que recupera aspectos um tanto quanto esquecidos do Simbolismo brasileiro.

Palavras-chave: Simbolismo, Impressionismo, Pintura e Poesia.

Abstract: In this article we seek to demonstrate how the Brazilian Symbolism contains interesting relationships with Impressionist school of painting and how these relationships pervade our Symbolism with examples of poems with strong features Impressionists. For this demonstration, we will use the poems of Maranhão Sobrinho, Pedro Kilkerry and Ernani Rosas, once the three poets are among those who could use the issue of the perception of light in composing his poems 
imagistic scenarios. Thus, we believe we can provide a text that recovers somewhat forgotten aspects of Brazilian Symbolism.

Keywords: Symbolism, Impressionism, Painting and Poetry.

A concepção de arte impressionista está por vários aspectos teóricos e pragmáticos ligada ao Simbolismo, embora possamos levantar diferenças específicas aos aspectos técnico-poéticos de uma e de outra. Juan José Balzi faz uma observação fulcral sobre esta questão técnico-poética, destacando as dificuldades entre pintura e poesia, sem com isso querendo afirmar que o Impressionismo seria mais pictórico e o Simbolismo mais literário:

"O Impressionismo, como o Cubismo e outros seus derivados são inovações tecnopictóricas. No entanto, os críticos e historiadores têm, geralmente, uma formação literária. Assim, quando em uma obra de história ou num curso de arte (onde o espaço dedicado à arte moderna e contemporânea é muito reduzida) chega-se ao capítulo que trata destes movimentos, a explicação torna-se sumária e insuficiente. Ou, quando se trata de livros ou ciclos específicos, ela resultará ao leitor ou ao ouvinte complicada demais ou falsamente erudita. É que, na realidade, a tradução de uma linguagem plástico-visual a outra escrita ou falada é mais difícil do que parece." (BALZI, p.8-9)

Poderíamos aqui evocar Lessing, acerca das distinções entre poesia e pintura, mas não creio que seja necessário. Afinal, nosso objetivo central aqui é demonstrar como três poetas nomeadamente simbolistas desenvolveram uma técnica impressionista de composição poética.

Neste sentido, convém destacar a especificidade característica do Impressionismo que é o trabalho com a luz, isto é, como a luz interfere e define nossa apreensão das cores e, mais, como a percepção destas cores pode ser modificada pela nuanças atmosféricas e pela distância que nos encontramos do objeto 
observado ou a posição em que nos encontramos em relação a ele. Desse modo, os pintores impressionistas se dedicaram ao desenvolvimento de uma técnica cromática muito singular no que se refere ao uso das cores e ao modo de pincelá-las, por vezes distorcendo o contorno dos objetos, suas formas, para nos dar a impressão dos efeitos dessa luminosidade na atmosfera. Não é por acaso que o nome do movimento se deve ao quadro "Impressão: Nascer do Sol"(1872) de C. Monet.

Podemos assim enumerar as características do Impressionismo a partir desta questão da luminosidade:

- As tintas devem salientar a forma que os objetos adquirem ao reflexo da luz num momento específico, haja vista que as cores da natureza constantemente, dependendo da hora da incidência da luz do sol;

- Desse modo é também uma pintura instantânea (captação do momento), recorrendo, inclusivamente, à fotografia, como forma de preparação para a pintura;

- Os contornos não são nítidos com destaque para relação mancha/cor;

- as sombras devem ser luminosas e coloridas, tal como é a impressão visual que nos causam.

- os contrastes de luz e sombra devem ser obtidos de acordo com a lei das cores complementares. Assim um amarelo próximo a um violeta produz um efeito mais real do que um claro-escuro.

No caso do Simbolismo, e poderíamos também levantar alguns pintores Simbolistas como Gustave Moreau, Odilon Redon ou Pierre Bonard - não raras vezes inseridos em listas de pintores impressionistas - também existe um aspecto referente à luminosidade, mas conceitualmente são processos distintos. No caso do Impressionismo a visão se sobrepõe aos demais sentidos, de forma que a Sinestesia decorre de uma expansão da visão 
para os outros sentidos, notadamente o tato. Ao passo que no Simbolismo não existe um domínio da visão sobre os demais, mas uma integração eqüitativa quanto possível dos sentidos. Talvez, por isso, a pintura simbolista seja, não raras vezes, considerada impressionista, uma vez que na pintura, a visão naturalmente e conceitualmente se sobrepõe, ficando a distinção nesta arte, muito ligada aos temas pintados do que à técnica.

$\mathrm{Na}$ poesia simbolista os experimentos impressionistas não foram poucos e vamos destacar aqui, no caso do simbolismo brasileiro, três poetas que levaram a cabo o que consideramos boas realizações de técnica impressionista em poesia.

Vamos começar por Pedro Kilkerry e seu poema "0 Cetáceo". 0 poeta passou a ser mais conhecido a partir do excelente trabalho de revisão de Augusto, Revisão de Kilkerry (1985). Numa dissertação de mestrado apresentada na UEPB (2009), Paulo Fernando Fonseca Ferreira faz (uma aliteração em ff...?) uma interessante análise dos poemas de Kilkerry e no caso específico do poema "O Cetáceo" começa por dizer:

"Em Cetáceo (ANEXO N), o olhar da liricidade capta na luz evasiva e o instante mais fluido que desmaterializa os objetos em densa plasticidade imagética. A cena só aparentemente se limita à forma parnasiana, uma vez que o soneto e as cadências métrica e acentual do verso (o decassílabo heróico) parecem diluir-se nos sentidos fugidios e nos aspectos precários da descrição (a marinha)." (FERREIRA, p. 97).

Transcrevemos a seguir o soneto:

\section{o Cetáceo}

Fuma. É cobre o zênite. E, chagosos do flanco, Fuga e pó, são corcéis de anca na atropelada. E tesos no horizonte, a muda cavalgada.

Coalha bebendo o azul um largo vôo branco. 
Quando e quando esbagoa ao longe uma enfiada De barcos em betume indo as proas de arranco. Perto uma janga embala um marujo no banco Brunindo ao sol brunida a pele atijolada.

Tine em cobre o zênite e o vento arqueja e o oceano Longo enfroca-se a vez e vez e arrufa, Como se a asa que o roce ao côncavo de um pano.

E na verde ironia ondulosa de espelho Úmida raiva iriando a pedraria. Bufa O cetáceo a escorrer da água ou do sol vermelho. (cópia fornecida por Álvaro Kilkerry. In: CAMPOS, 1985).

Destacaremos aqui a questão do trato com a luminosidade no poema e a forma como a percepção desta modifica a escrita do poema por meio do uso de metáforas e metonímias como recurso lingüístico para exploração destas percepções:

Os primeiros dois versos são compostos por dois períodos. Um, simples, de uma só palavra ("Fuma") e outro compreendendo as demais. Ao colocar "Fuma" logo no início do poema, já temos aí uma referência impressionista. Lembremos da fala de Monet: "A única maneira de se dar a impressão da realidade é chegarmos a representar a atmosfera; isto que está entre você e eu (abre e fecha a mão ante os olhos de Manet, como se apanhasse a fumaça do seu cigarro)." (BAZI, p. 27) ${ }^{1}$. De fato, a questão da relação entre a atmosfera e a luz é um dos pontos centrais da técnica impressionista, como já notamos na apresentação de suas características.

O segundo período ("E, chagosos do flanco, Fuga e pó, são corcéis de anca na atropelada.") nos apresenta uma metáfora, ao que me parece, já resultado desta interferência da atmosfera.Os corcéis são imagens percebidas a partir do movimento das nuvens no horizonte, sob a luz do Sol, o efeito rosicler.

E o quarteto se encerra com um terceiro período que

\footnotetext{
${ }^{1}$ As frases e citações de falas de pintores inseridas no livro de Bazi, ao que me parece, são originárias do estudo de John Rewald, História do Impressionismo. Trad. Jefferson Luís Camargo. São Paulo, Martins Fontes, 1991.
} 
compreende os dois versos seguintes: ("E tesos no horizonte, a muda cavalgada. / Coalha bebendo o azul um largo vôo branco."). Continuando na descrição da metáfora anterior, o poeta baiano salienta que o tropel de corcéis encontrar-se em momento de tensão - extáticos ao momento instantâneo de sua percepção - mas num processo sinestésico, salienta que sua cavalgada é "muda", o que é um contra-senso que desvela a metáfora, uma vez que uma cavalgada de corcéis em disparada e tesos seria das mais ruidosas. Esta sinestesia (audição / visão) fornece ao leitor uma pista para a compreensão da metáfora. O verso seguinte, considerado por Augusto de Campos um dos mais belos do simbolismo brasileiro, um alexandrino com os hemistíquios $1^{\circ}$ : “Coalha bebendo o azul - acentos na 1. $\underline{\text { a }}$ - resultante de uma união das sílabas co+a -, 3. ${ }^{\text {a }}$ e 6. e 2. ' hemistíquio: "um largo vôo branco" - com acentos na 2. ${ }^{\mathrm{a}}$, 4. ${ }^{\mathrm{a}}$ e 6. ${ }^{\mathrm{a}}$ sílabas - mantendo-se o hiato de "vôo". De modo que o primeiro só tem acentos em sílabas ímpares e o segundo em pares, como num processo de equilíbrio barroquista. E a união dos dois hemistíquios se faz por um eco: “o + a - zUL // UM", para analogia com o movimento contínuo das nuvens no céu. No eco, o som se propaga, as nuvens por sua vez, se metamorfoseiam continuamente, ao discurso poético de um proteu-poeta.

Observemos três quadros impressionistas que podemos relacionar ao descrito no primeiro quarteto do poema:

O primeiro é o quadro "San Giorgio Maggiore ao anoitecer Claude Monet", notemos o modo como os tons de azul, amarelo e vermelho são apresentados para compor a percepção do horizonte. 


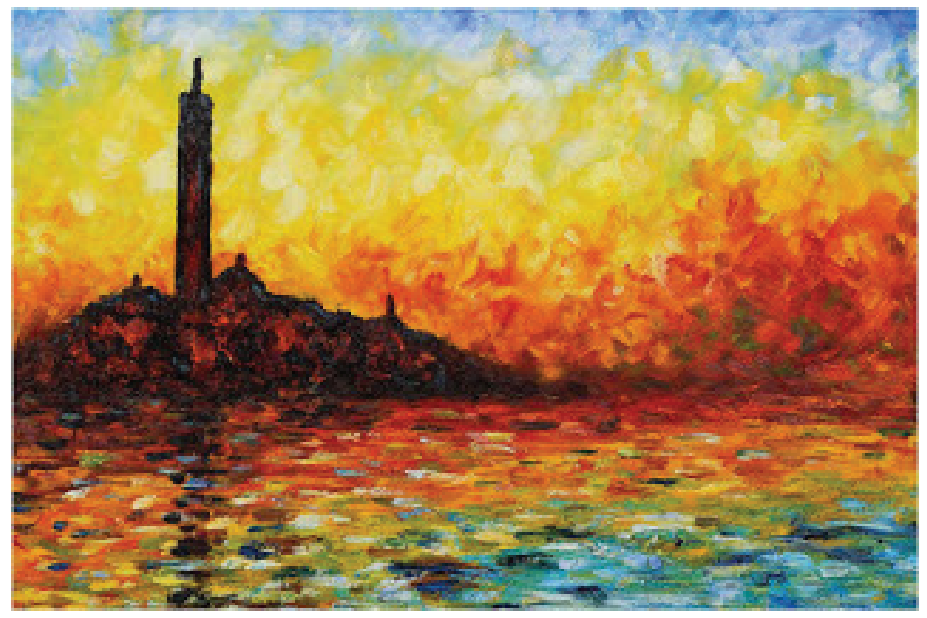

Ou este de André Derain, Ponte em Charing Cross (1906):

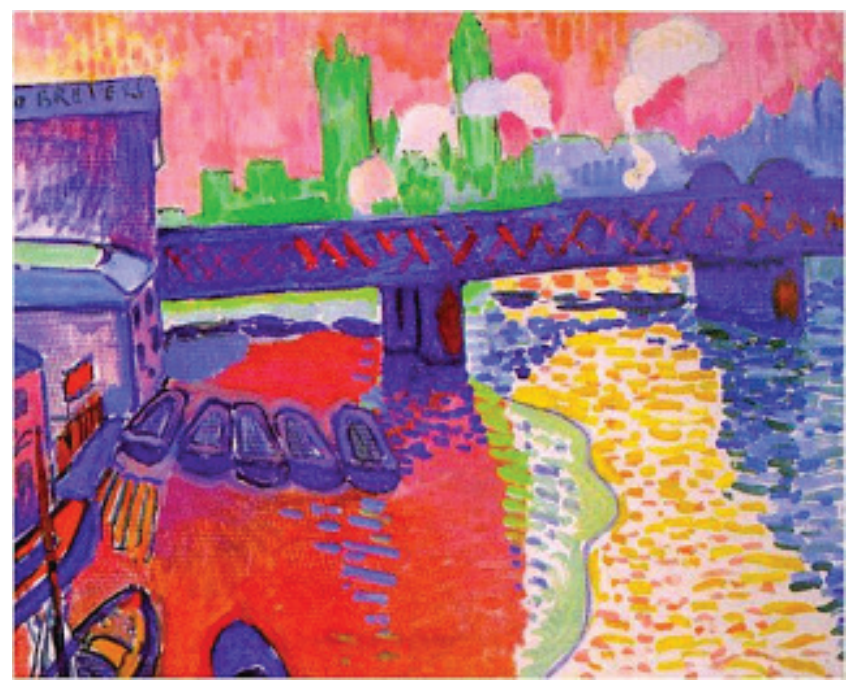

Notemos a intensidade das cores do céu avermelhado e a água do canal, próximo às margens, onde estão os barcos. 0 modo como o tom avermelhado está relacionado à percepção da sombra causada pelas construções sobre o canal.Os contornos difusos e o trabalho com o reflexo do céu e da ponte nas águas. 
Ou este, de Franz Marc, Paisagem com Cavalo (1910), em que notamos o modo como a cor do cavalo é avermelhada, mas a crina de um forte azul. E os tons de azul e vermelho em pequenas porções no cenário do campo amarelo e verde:

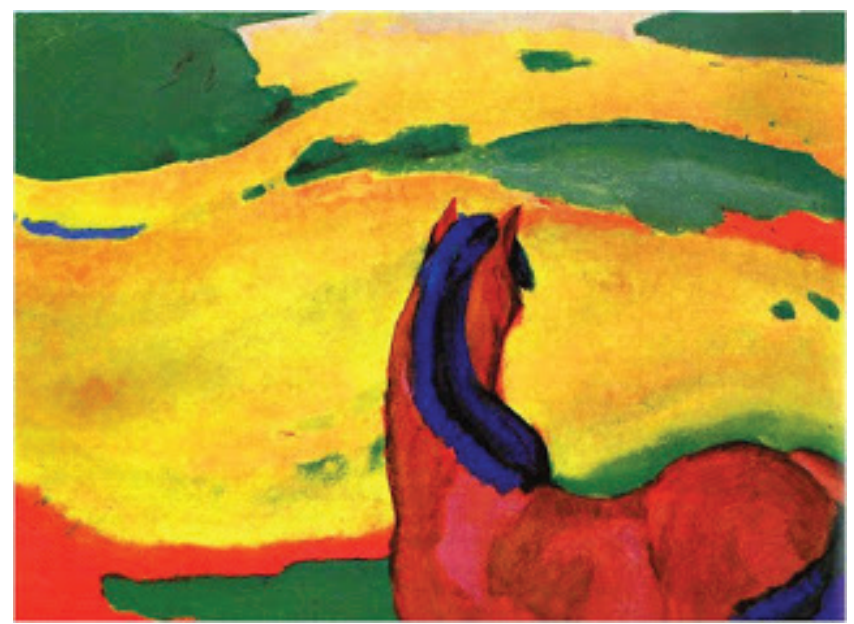

Passemos à análise do segundo quarteto. Que contém dois períodos de dois versos cada. O primeiro ("Quando e quando esbagoa ao longe uma enfiada / De barcos em betume indo as proas de arranco."), nos apresenta o cenário da linha do horizonte mar/céu também pincelada com imagens de barcos. 0 advérbio "ao longe" orienta-nos espacialmente para imaginação da cena proposta. Podemos notar aqui também a questão do uso do negro no Impressionismo. Existe uma tendência a evitá-lo tanto quanto possível, pois por definição, o preto é ausência de cor, o que invalidaria a questão da percepção da cor com relação à luminosidade. Assim, o "betume" dos barcos estaria mais para o azul, já citado no último verso do quarteto anterior, talvez num tom mais escuro. 0 verbo "esbagoar", tirar o bago, abrir a vagem, aqui em sentido conotativo, seria a seqüência de barcos aparecendo ao horizonte, em fila, como os grãos numa vagem de feijão, metáfora original. Na expressão 
"proas de arranco", ainda temos por extensão, o verbo, arrancar, contíguo metonimicamente ao sentido de esbagoar.

Notemos o tom com que Monet pinta os barcos no seu famoso quadro "Impressões do Nascer do Sol” (1872):

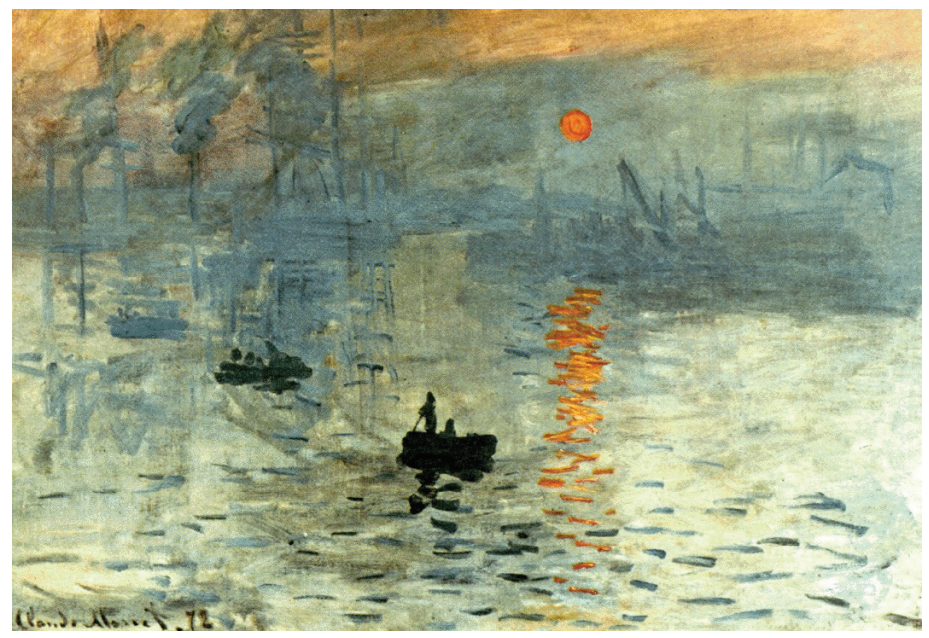

0 tom escuro dos dois pequenos barcos mais próximos e os espectros azulados e difusos dos outros barcos ao que nos parece, numa neblina que vai aos poucos se diluindo ante o Sol vermelho que vai nascendo e já pondo seu reflexo sobre a água.

O segundo período deste quarteto ("Perto uma janga embala um marujo no banco / Brunindo ao sol brunida a pele atijolada."), apresenta-nos com o advérbio de lugar "Perto" a possibilidade de colocação da cena que vai se descrita para compor o cenário: uma jangada mais próxima do que os distantes barcos ou as nuvens que lembram cavalos no horizonte. Perto o suficiente para olharmos que na jangada está um marujo de pele bronzeada. A personificação da jangada que "embala um marujo no banco" dá um sentido afetivo, singelo, à cena. 0 verbo brunir, no sentido de dar brilho, fazer luzir, enriquece o sentido impressionista da percepção da cena da jangada e do jangadeiro sob a luz do Sol. Apreciemos o tom da pele em “Contos Bárbaros”(1902) de Paul Gauguin: 


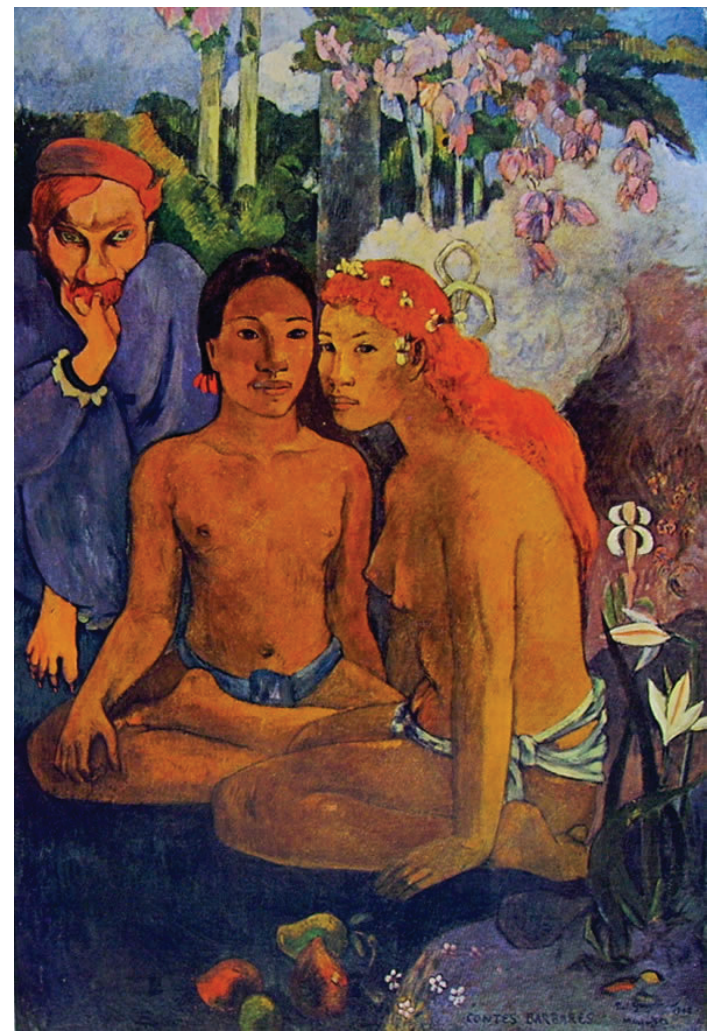

O modo avermelhado como ele apresenta o tom da pele das duas figuras seminuas, algo indianas. 0 sombreamento que ele dá para captação dos efeitos de luz.

No poema de Kilkerry, a expressão "pele atijolada" é uma adjetivação metonímica, uma vez que a cor do tijolo - barro vermelho - é usada para se referir à cor da pele do marujo brilhando sob a luz do Sol.

No primeiro terceto temos um só período. Começa com o verbo "tinir", que é relativo à produzir som no metal ou vidro. No caso, metal, pois logo a seguir fala na cor do cobre. Temos uma sinestesia, audição / visão. 0 zênite reforça a idéia de percepção da luz Solar com intensidade, uma vez que a cor do cobre - avermelhada, cor de fogo - associa-se à idéia de um ponto mais central e elevado do Sol 
naquele momento. Assim, com relação ao quarteto inicial já temos um horário diferente, já que no primeiro o rosicler é que dominava a percepção que o poeta tem das nuvens e dos barcos no horizonte, portanto, o amanhecer. E agora, o Sol a pino.

Neste terceto, três elementos da Natureza se relacionam: o Sol (na sinestesia cobre/tinir - brunir/zênite), o vento que arqueja (personificação e metonímia) e o oceano que enfroca-se (metáfora). 0 vento é personificado em um ser que está esbaforindo, ofegante, devido ao calor do Sol, ao mesmo tempo, esta respiração arquejante é natural de quem tenha dificuldade em respirar naturalmente o ar (vento), assim, nesta personificação, existe também uma metonímia em que o ser respirante é substituído pelo respirado. 0 vento ao enfrocar-se, isto é, fazer frocos (tênues filamentos) que costumeiramente relacionamos à idéia de flocos, é uma metáfora para as espumas das ondas do mar. Uma vez que o oceano LONGO permite ao poeta imaginá-lo na ação de enfrocar-se, cujo resultado imagético são suas ondas. E a ação de arrufar, que tanto pode relacionar-se à idéia de fazer rufo (produzir som), como a de ouriçar ou arrepiar e mais ainda a idéia de zangar-se, que se liga à vela da jangada, côncava pela ação do vento, mas ao mesmo tempo, como alguém que zangado enche as bochechas, portanto, metaforicamente vendo o pano branco da vela. 0 verbo "roçar", no sentido de raspar, tornar áspero, continua a imagem da vela em relação ao vento.

A riqueza de figuras deste terceto, a complexa relação que se estabelece entre elas é como se o poeta Pedro Kilkerry concebesse que se na pintura impressionista o tom dominante é o trabalho com as cores de modo a demonstrar, por meio delas, a relação com a luz, na poesia, as cores são dadas pelo uso de figuras, portanto, utilizálas para descrever a forma e o tom dos seres e das coisas seria um recurso impressionista.

A relação cor / figuras é bem discutida na Retórica, na Poética, em diferentes autores, desde Aristóteles e para tanto, basta lembrarmos do parágrafo 2, do cap. XXVI da Arte Poética de Aristóteles: 
"Sendo o poeta um imitador, como o é o pintor ou qualquer outro criador de figuras, perante as coisas será induzido a assumir uma dessas três maneiras de as imitar: como elas eram ou são, como os outros dizem que são ou dizem que parecem ser, ou como deveriam ser."

Por outro lado, a relação cor (visual) com palavras (som, forma) está já fundamentada no Siumbolismo, em Rimbaud (Voyelles), em Baudelaire (Correspondances), em René Ghil e seu quadro de relações sinestésicas.

No último terceto, temos dois períodos - como no segundo quarteto - e o primeiro período ("E na verde ironia ondulosa de espelho / Úmida raiva iriando a pedraria") a complexidade das figuras continua se desenvolvendo ricamente. A relação sonora ironia / iriando que se expande para uma aliteração (ironia - raiva - iriando - pedraria) já instaura uma série de figuras: a verde ironia é o reflexo do céu azul-branco nas águas verdes do mar, ondulosa (esbranquiçada, de enfrocar-se) e a raiva é a força com que se iria, dá brilho, matizam-se as cores. E aqui "pedraria” que é uma transformação metonímica de conteúdo para formulação metafórica, haja vista que pedra e água do mar são elementos bem distintos quanto à dureza e textura, mas por outro lado, a formulação anterior das espumas, fica reforçada se pensarmos em pedras (rochas) contra as quais a água do mar bate mais fortemente. Se ao longe vemos barcos, e perto vemos a jangada (lembremos ainda do adjetivo atijolada), a idéia de colocarmos no cenário pedras contra as quais a água bate não é de modo algum fugir ao texto. E, ainda, se pensarmos que isto é a visão que o poeta tem de um cenário da natureza, cabe nos perguntar, em que posição se coloca o poeta, e deve estar mais para cá da jangada, ou seja, próxima as pedras ou praia.

Observemos, para efeito de comparação, como Renoir na tela $L a$ Grenouillere (1869) pinta a textura da água do calmo lago, como coloca os barcos sobre a água e o jogo de reflexos entre o verde da vegetação e a água. 0 líquido tem sua densidade aumentada numa impressão visual que busca a transcendência do visual para o tátil. 


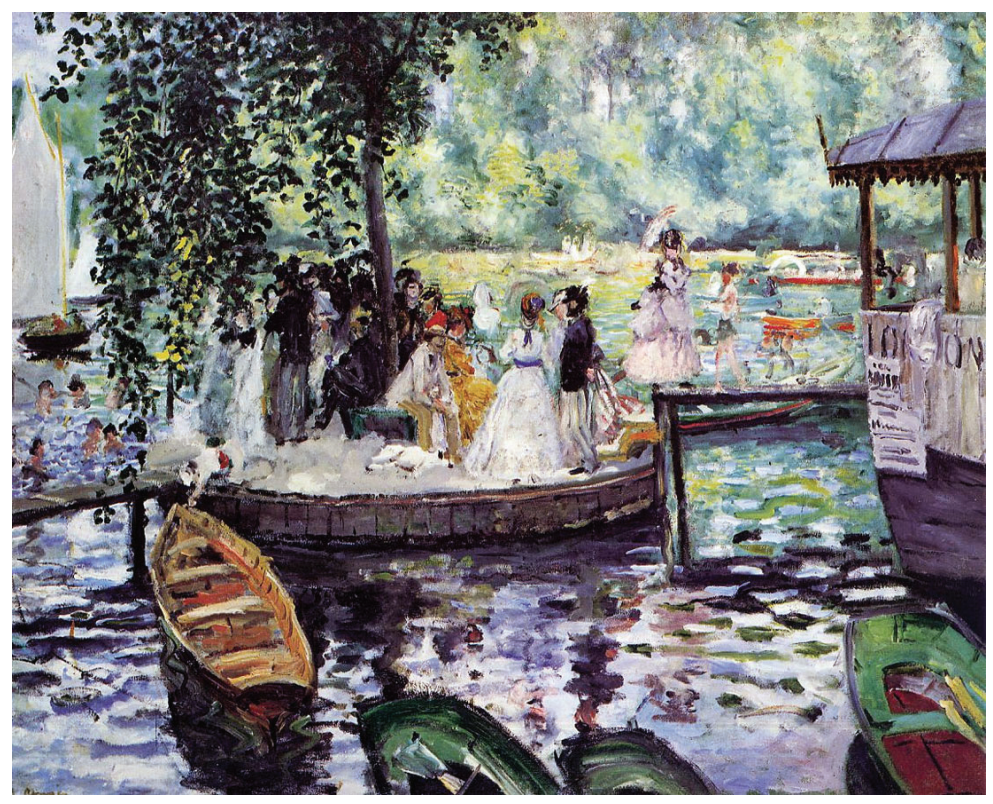

No último período do poema, como uma chave de ouro, temos o aparecimento do ser que dá título ao poema. A baleia, enorme se comparada à frágil jangada, surge das águas, ou aliás, e aí é que se coloca uma nova dimensão perceptiva: a baleia escorre água, no caso de emergir, ou escorre luz no caso de submergir, ou ambas as coisas em ambos os casos. A luz líquida, a água-pedra, enfim uma transformação alquímica dos elementos, a busca da densidade da cor na luz impressionista. 0 verbo no presente do indicativo, "Bufa", retoma sonoramente a primeira palavra do poema por efeito aliterativo: Fuma / Bufa, e o confronto F-B (fricativa surda substituída por oclusiva sonora) é bem o barulho que o enorme animal produz no cenário, ao agitar das águas - como as águas nas pedras - ao respiradouro, ao bater das nadadeiras na superfície maior que o roçar do vento na côncava vela, e ainda, o tom da pele da baleia, expandindo a pele atijolada do marujo na janga.

Enfim, um dos mais ricos poemas simbolistas da literatura brasileira, e ao mesmo tempo, exímio exercício de observação impressionista em versos. 
Outro poema que trataremos de Pedro Kilkerry é "O Verme e a Estrela”. O poema já foi gravado por Adriana Calcanhoto, musicado por Cid Campos, filho de Augusto de Campos. 0 poema que se constrói num interessante jogo sonoro entre as palavras verme e epiderme e numa antinonímia com a palavra luz, assim perfazendo um jogo de sinestesias, uma vez que a luz se percebe pela visão, ao passo que a epiderme é táctil:

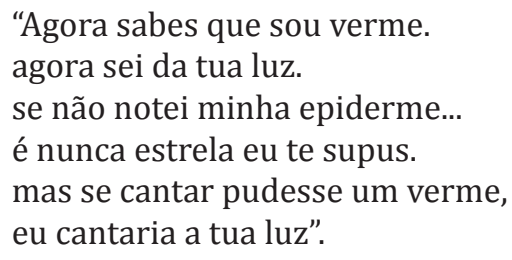

"Agora sabes que sou verme. agora sei da tua luz. se não notei minha epiderme... é nunca estrela eu te supus. mas se cantar pudesse um verme, eu cantaria a tua luz".

A percepção de si mesmo, e o reconhecimento da condição inferior diante da suposta estrela coloca o eu-lírico num embate contínuo como uma arrastar de verme pela superfície terrena em busca do entendimento da enorme distância que o separa da luz estelar. Evidentemente, tal condição, metáfora da inatingibilidade de algum desejo ou amor idealizado se compraz na hipérbole desta enorme distância e diferença. A exígua dimensão do verme e a imensa distância, luminosidade e tamanho de uma estrela. Assim, mais do que simbolista, este poema, guarda em sua estrutura o jogo das impressões sensoriais, o jogo da luz que atinge um verme, que ao que nos parece, não dotado de visão, como é característico dos vermes, mas com epiderme sensível o suficiente para percepção do calor luminoso.

\footnotetext{
"Olho examino-me a epiderme olho e não vejo a tua luz vamos que sou talvez um verme estrela nunca eu te supus olho examino-me a epiderme Ceguei! ceguei da tua luz".
} 
Tratemos agora de um poema de Ernani Rosas (1886-1954), poeta de quem Augusto de Campos, escreve num artigo, em que demonstra as influências e as relações de recriação com a poesia de Mário de Sá-Carneiro e de Eugênio de Castro, além de sua admiração por Mallarmé:

\begin{abstract}
"Se a linguagem de Ernani Rosa tem a sua individualidade até certo ponto afetada pela porosidade que oferece a outros estilos -e nisso ele difere de Pedro Kilkerry, dono de um idioleto mais pronunciado -, essa circunstância não chega a tolher-lhe a invenção, patente na reelaboração crítica eseletiva queleva o poeta a soluções extraordinárias e a configurações lingüísticas inteiramente estranhas à tradição e ao contexto brasileiros." (CAMPOS, 1990).
\end{abstract}

O poema escolhido para trabalho neste artigo é "Salomé", um soneto que trata de figura carismática, simbólica e cara ao Simbolismo em geral ${ }^{2}$. Se o primeiro verso começa com uma metáfora até certo ponto previsível, a de colher semelhança entre a dança de Salomé e a de uma mariposa ("Ó Bailarina, oh! mariposa inquieta!"), logo nos versos seguintes o poeta desfila um conjunto original de metáforas: as cores das gemas e a cor do entardecer ("Aljofrada da gema de uma tarde."), entre Salomé e um barco ágil ("És nume, Salomé, ágil goleta..."), e ainda, uma sinestesia surpreendente extraída da relação entre o incenso que volteia no ar e a cor do ouro derretido ("dentre o incenso da sombra que oura e arde..."), recuperando a imagem do Sol ao entardecer ante a fumaça do incenso.

$\mathrm{Na}$ segunda estrofe, continuando com uma base imagética estelar, agora citando o cometa e a Lua. No que se refere ao cometa, estrela-errante, se num primeiro momento pode parecer uma

\footnotetext{
${ }^{2}$ Sobre a figura de Salomé no Simbolismo brasileiro, veja meu texto "Starlets do Simbolismo Brasileiro", publicado no livro Monografias de Literatura, Teatro, Comunicação e Semiótica. São Paulo, Epsilon Volantis, 1999. Sobre a figura de Salomé no Sensacionismo europeu, indicamos o estudo de Álvaro Cardoso Gomes, "Salomé, Starlet Simbolista (Eugênio de Castro", publicado no seu livro O Poético: Magia e Iluminação. São Paulo, Perspectiva, 1989.
} 
metáfora fácil para Salomé, a forma como Rosas escreve o verso é que recupera para a linguagem a capacidade criativa da mesma, desvelando do óbvio, a novidade: "Espectro errante de um cometa absorto / após a bacanal 'saturniana'!...”. Deste modo, as expressões "espectro errante" e "bacanal saturniana" se dinamizam numa metaforização dos movimentos da dança de Salomé. No verso seguinte, a imagem da flor perfumada (nardos) e sua proximidade com o cenário do Mar-morto, de modo que a dança de Salomé seja também um signo de morte.

0 último verso deste segundo quarteto, apresenta a Lua como "irial" e "sibariana”. Irial por ser a percepção das cores dos véus da dança de Salomé, sibariana, pela luxúria e hedonismo da dança sensual.

0 primeiro terceto, o poeta redimensiona a imagem da dança de Salomé, para uma nova concepção, a transformação de seus véus e seus movimentos metaforizados na imagem estelar de um céu noturno claro, em que a névoa estelar da Via-Láctea é um dos véus de Salomé caindo sobre a Terra:

"Chovem do céu os raios da nova aurora sobre seu corpo d'âmbar colmado da via Láctea que su'alma olora...”

Metáfora hiperbólica, original, criativa, sinestésica (raios visão; corpo - tato; âmbar, olor - olfato). E criando uma sugestão de esperança ("raios da nova aurora") em razão da beleza, como se as próprias palavras do poema dançassem sobre os significados e as imagens, a cada verso, palavra, rima ou sílaba.

0 último terceto, a imagem estelar volta-se para o significado da dança de Salomé, para a morte que causa - do profeta João Batista - mas ao mesmo tempo, o poeta atenta para a beleza da dança, para a sensualidade fulgurante, como se demonstrasse que o "Mal", que aparece no último verso entre aspas, se relativiza diante do prazer estético da visão e da audição da música e da dança: 
"Numa auréola de Luz e alegoria

Esvaindo-Te em Sonho musicado, para a glória do "Mal" que a irradia..."

A aproximação sonora entre "auréola" e "alegoria" abrindo o terceto e a expressão "Sonho musicado", que propõe, ao meu ver, uma nova possibilidade de sinestesia, porém, não entre os sentidos usuais, mas entre a audição (musicado) e o inconsciente (o sonho), ou seja, ouvir a música em sonho, findando com a irradiação (visão) do "Mal" relativizado.

Podemos, agora, ler o poema observando o quadro de Gustave Moreau, Salomé, chamada de tatuada (1871):

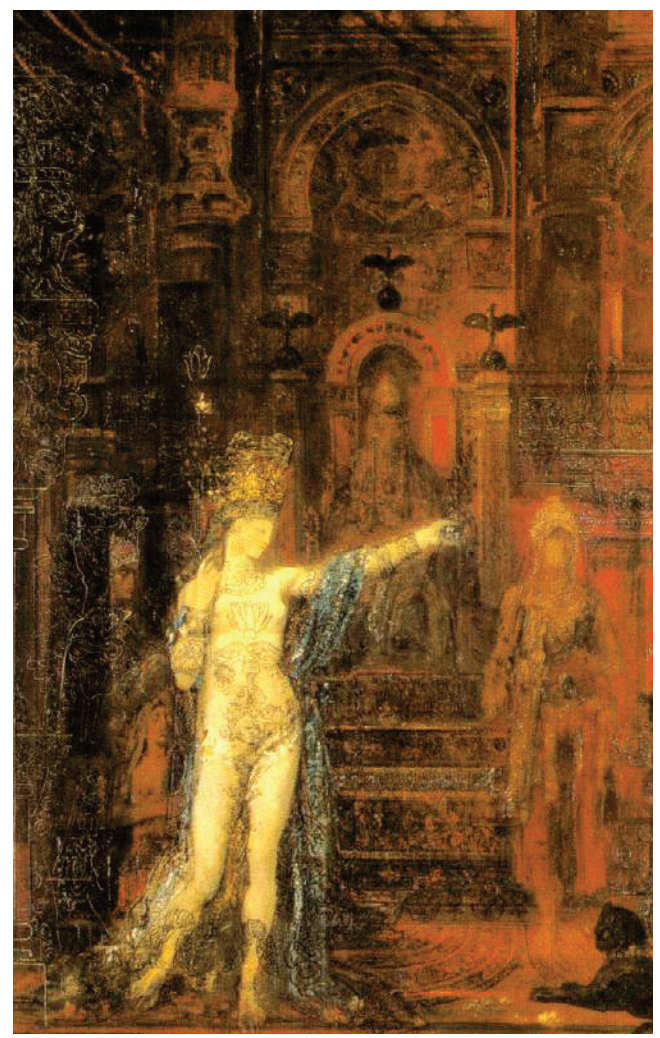


Observemos no quadro de Moreau, o véu azul caindo-lhe dos braços, a sutileza transparente dos tecidos, a luminosidade que cai sobre a figura da dançarina enquanto ao redor, as demais figuras encontram-se numa penumbra avermelhada, como o entardecer, destacando-se ao fundo, mas em posição central no quadro, a figura atenta e atônita de Herodes. É muito provável que Ernani Rosas não tivesse visto o quadro, uma vez que sendo um poeta pobre, de parcos recursos, morrendo esquecido no Rio de Janeiro, vindo de Florianópolis, além de sofrer discriminação por ser gago e homossexual, não se tem notícia de que tivesse ido ao estrangeiro, onde poderia ver o quadro de Moreau, nem que tivesse alguma reprodução acessível. Mas, o modo como Rosas apresenta sua Salomé, é um bom exemplo da utilização dos recursos impressionistas relativos à valorização do jogo de luz, das impressões visuais sobre os sentidos e das correlações de sinestesia que isto pode provocar.

Mas poucos poetas simbolistas foram tão impressionistas quanto Maranhão Sobrinho (1879-1915). Poeta de versificação rica, original e extraordinária, utilizando imagens e metáforas como quem pinta quadros, Maranhão Sobrinho, porém, como a maioria de nossos poetas simbolistas, caiu no esquecimento, sendo lembrado eventualmente em parcos estudos e artigos.

Destacaremos dois sonetos deste poeta singular. 0 primeiro é "Interlunar", poema muitas vezes lembrado pela sonoridade singular de suas rimas (-ânio, -ênio, -ínio, -ônio, únio). 0 poema constrói uma imagem do pôr-do-Sol, tema caro aos simbolistas e aos impressionistas, por motivos próximos, mas diversos. O Sol, metaforizado em "hoplita messênio", "recolhido essênio", vencido se esconde num horizonte que é um "planalto de urânio". No segundo quarteto, temos a sugestão da tumba de Mallarmé, atrás da qual os últimos raios de Sol se escondem:

\footnotetext{
"Veloz como um corcel, voando num mito hircânio, tremente, esvai-se a luz no leve oxigênio da tarde, que me evoca os olhos de Estefânio Mallarmé, sob a unção da tristeza e do gênio!"
} 
A riqueza das sonoridades em Maranhão Sobrinho pode ser bem representada pelo primeiro verso deste quarteto: VELOZ ComO um-m-m-m CorcEL Voan-n-n-do num-m-m-m mIto hIrc-ân-n-n-io. As sensações sinestésicas trabalhadas com detalhe, a sensação da velocidade do vôo de um corcel - o que nos lembra um verso de Pedro Kilkerry em "O Cetáceo" - a Luz que se esvai ao entardecer na atmofesra (oxigênio) e os olhos de Mallarmé, porém, fechados, uma vez que está morto.

Nos tercetos a Noite se sobrepõe ao cenário, uma vez que o Sol, vencido, se esconde. É domínio das sombras, porém, pétreas (Ônix), duras, convincentes sobre toda a imagem apresentada. 0 último brilho do rosicler ao horizonte - o famoso crepusculismo simbolista - é a testemunha de um assassinato, a da luz, que por sua vez, é a metáfora da poesia de Mallarmé.

As "torres medievais" são impressões da visão do túmulo do poeta francês. Assim, neste soneto, Maranhão Sobrinho, presta homenagem ao seu poeta preferido, tendo se notabilizado pela constante referência que faz à obra do simbolista francês.

Em outro poema, "Equatorial", também um soneto, o poeta Maranhão Sobrinho nos apresenta a partir de um cenário inusual na poesia, um lodo visguento ("Sobre o lodo escorrega o musgo. A renda") e os insetos e vermes que por lá vivem ("E na lama, que a lesma azul, meandra de rugas" / .../ "arrastam-se pulsando as moles sanguessugas"), um conjunto de versos que fazem por trabalhar com maestria a sonoridade, as sinestesias e as metáforas, quase como quem pintasse o lago impressionista onde brotam as flores aquáticas, porém, num tom mais lúgubre e escuro.

A tropicalidade evocada no poema é justamente o cenário oposto daquela "multidão de insetos" idealizada no poema de Bilac ("Pátria" - "Não verás país nenhum como este”...), uma vez que aqui, em Maranhão Sobrinho é o conjunto de imagens dum cenário algo asqueroso, mas rico em vida, em que o que para nós é de sentido de nojo, para a vida é berço de criação e transformação: 
"Sobre o lodo escorrega o musgo a renda. Em viços soberbos, o esplendor das aquáticas sarças beira o líquido espelho em que, de espantadiços olhos, banham-se, ao sol, as branquicentas garças."

Comparemos, por exemplo, o poema "Tropical" com dois quadros de Claude Monet, "Estudo da Água" e "Nenúfares". No primeiro, o movimento ríspido, as cores escuras dão nos a impressão duma água barrenta, lodosa, sem reflexo; ao passo que o segundo, vivo em cores, quase que translúcido, nos remete a um cenário de vida.

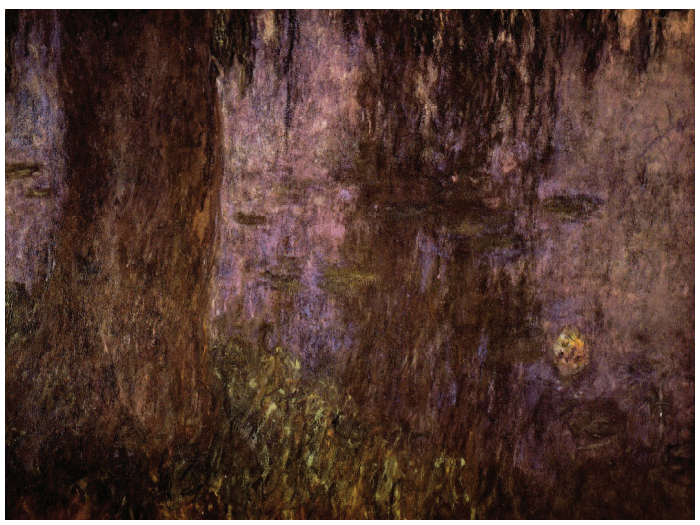

Claude Monet, Estudo da Água

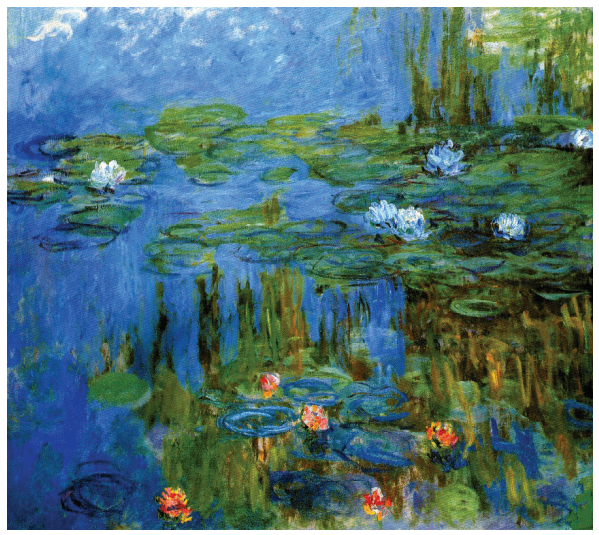

Claude Monet, Nenúfares. 
Porém, em ambos, o que se sobressai é a busca pela compreensão da luz como determinante da imagem e, portanto, da pintura. Daí o Impressionismo ser considerado a escola de pintura que trabalha a forma de como a luz impressiona nossa percepção visual e estabelece os limites de nossa capacidade visual. Neste sentido, é uma técnica que busca a recuperação de nossa capacidade de olhar para além dos limites da convencionalidade cotidiana. Em Maranhão Sobrinho, por seu turno, a par de sua influência mallarmaica, existe uma proposta análoga, só que o poeta - como é característico da poesia, lembramos Lessing - o faz pelo uso da palavra, pelas sinestesias, pelas metáforas e pela exploração da sonoridade com a intenção última de redescobrirmos a capacidade imagética da imaginação.

Assim, ao fim e ao cabo deste artigo, espero ter demonstrado como o Simbolismo brasileiro guarda interessantes e criativos exemplos da proximidade com o Impressionismo. E se o Impressionismo, costuma ser referenciado como escola de pintura em primeiro plano, não é de se menosprezas os modos como se utilizou da técnica impressionista na composição de poemas no Simbolismo brasileiro.

\section{Referências bibliográficas}

ARISTÓTELES. Arte Retórica e Arte Poética. Rio de Janeiro, Ediouro, 2001.

BALZI, Juan José. O Impressionismo. São Paulo, Ática, série Princípios, vol. 225, 1992.

CAMPOS, Augusto de. Revisão de Pedro Kilkerry. São Paulo, Brasiliense, 1985. 
CAMPOS, Augusto de. "O Enigma Ernani Rosas". São Paulo, Revista da USP, Set./out./nov., 1990, p. 157-172.

FERREIRA, Paulo Fernando Fonseca. $O$ Verbo Encarnado na Alma Cósmica: A Poesia de Pedro Kilkerry. Dissertação de Mestrado, orientador: Prof. Dr. Milton Marques Júnior. João Pessoa, UFPB, 2009.

LESSING, Gotthold Ephraim. Laocoonte. São Paulo, Iluminuras, 1999.

REWALD, John. História do Impressionismo. São Paulo, Martins Fontes, 1991.

ROSAS, Ernani. Poesias. Em: Orfeu Spam Apostilas. Disponível em: http://www.jayrus.art.br/Apostilas/ LiteraturaBrasileira/Simbolismo/Ernani Rosas.htm

SOBRINHO, Maranhão. Poesias. Em: Orfeu Spam Apostilas. Disponível em: http://www.orfeuspam.com.br/Apostilas/ LiteraturaBrasileira/Simbolismo/MARANHAO_SOBRINHO. $\underline{\mathrm{htm}}$ 


\section{UM SIMBOLISTA NA PERIFERIA DO CAPITALISMO: SONHO, TRANSCENDÊNCIA E QUEDA NA POÉTICA DE CRUZ E SOUSA}

\section{A SYMBOLIST AT THE PERIPHERY OF CAPITALISM : DREAM, TRANSCENDENCE AND FALL IN THE POETICS OF CRUZ E SOUSA}

RESUMO: De uma perspectiva comparativa, o artigo observa a vinculação criativa do poeta Cruz e Sousa ao movimento internacional simbolista, na sua condição de intelectual brasileiro. Através de trechos de prosa poética e do poema "Violões que choram...", indica-se a percepção estética do escritor em relação a temas e técnicas do simbolismo. 0 objetivo é compreender traços característicos da poética de Cruz e Sousa, entendida seja como estilo pessoal de composição, seja como reflexão programática acerca da escrita.

PALAVRAS-CHAVE: Cruz e Sousa; Simbolismo; Poética.

ABSTRACT: From a comparative perspective, the article observes the creative link of the poet Cruz e Sousa to the international Symbolist Movement, in his specific Brazilian intellectual condition. Through excerpts of poetic prose and 
the poem "Guitars that cry...", it is indicated the aesthetic perception of the writer in relation to themes and techniques of symbolism. The goal is to understand some of the characteristic features of Cruz e Sousa's poetics, understood both as a personal compositional style, as a programmatic reflection on the writing.

KEYWORDS: Cruz e Sousa; Symbolism; Poetics.

Tenho que tragar tudo e ainda curvar a fronte e ainda mostrar-me bem inócuo, bem oco, bem energúmeno, bem mentecapto, bem olhos arregalados e bem boca escancaradamente aberta ante a convencional banalidade. Sim! suportar tudo e cair admirativamente de joelhos, batendo o peito, babando e beijando o chão e arrependendo-me do irremediável pecado ou do crime sinistro de ver, sonhar, pensar e sentir um pouco...

Cruz e Sousa

\section{0 influxo externo}

"Je suis l'Empire a la fin de la decadénce" é o incipt do poema "Langueur", publicado em 1883 por Paul Verlaine na revista Le chat noir (apud DIDIER, 2009, p. 223)..$^{1} 0$ verso expressa bem o sentimento de fin de siècle vivido por parte da classe culta europeia: em uma imaginária correspondência entre o final do século XIX e o império romano à época das invasões bárbaras, a sensação é a de viver um período de crise e declínio, onde o poeta abandona-se a um sentimento de langor e fascínio pela própria condição "decadente". ${ }^{2}$ Depurada do sentido puramente negativo, a denominação acaba

\footnotetext{
${ }^{1}$ O gato negro; "Langor"; "Eu sou o Império ao fim da decadência” (tradução nossa). 2 "fim de século" (tradução nossa).
} 
encontrando ampla aceitação entre os artistas alinhados contra o pensamento positivista, expressão de uma mentalidade burguesa que constrói o próprio bem-estar a partir do progresso científico. ${ }^{3}$ Desta perspectiva, os decadentistas reivindicam o reconhecimento dos componentes irracionais da obra de arte e as sensações inimitáveis advindas do contato com a mesma, na exaltação do gosto e do refinamento do esteta (CASADEI; SANTAGATA, 2011).

Ao decadentismo é estreitamente ligada a corrente do simbolismo, que encontra em Jean Moréas um de seus primeiros teóricos. Em 1886, sob solicitação dos editores do Le Figaro (1886, p. 150) a respeito da "école de poètes et de prosateurs dits 'décadents'”, o literato expõe os princípios fundamentais da nova corrente, nomeada por ele "simbolismo", palavra que considera "la seule capable de désigner raisonnablement la tendance actuelle de l'esprit créateur en art" (MORÉAS, 1886, p. 151). ${ }^{4}$ Como inimigo de "l'enseignement, la déclamation, la fausse sensibilité, la description objective", tal espírito busca "vêtir l'Idée d'une forme sensible" (MORÉAS, 1886, p. 151). ${ }^{5}$ Em outras palavras, tratar-se-ia de dar expressão sensorial às ideias primordiais - que existiriam no mundo concreto por afinidades e correspondências -, tornando-as acessíveis através da forma artística

Do ponto de vista da história do movimento, Moréas (1886, p. 151) adota a perspectiva evolucionista característica do século XIX, assinalando que "chaque nouvelle phase évolutive de l'art correspond exactement à la décrépitude sénile, à l'inéluctable fin de l'école immédiatement antérieure", pois o que em um determinado momento constitui grande novidade, com o tempo se transforma em lugar comum. ${ }^{6}$ Neste concatenar-se tipicamente moderno,

\footnotetext{
${ }^{3}$ Le décadent (1886-1889) é a revista oficial do movimento, dirigida por Anatole Baju.

4 "a única capaz de designar razoavelmente a tendência atual do espírito criador na arte" (tradução nossa).

5 "o ensinamento, a declamação, a falsa sensibilidade, a descrição objetiva" (tradução nossa); "vestir a ideia com uma forma sensível" (tradução nossa).

6 "cada nova fase evolutiva da arte corresponde exatamente à decrepitude senil, ao
} 
o simbolismo coloca-se como reação ao domínio das estéticas Realista, Naturalista e Parnasiana que, por sua vez, tinham afirmado a própria existência na história literária recusando o subjetivismo romântico que as precedera, opondo a este a "objetividade" da narração, de acordo com a mentalidade cientificista do período (JUNKES, 2006).

Em ruptura com o passado recente e estabelecendo laços de continuidade com o romantismo, a escola simbolista volta a conferir importância à percepção do sujeito criador. Para o poeta, a realidade deixa de ser o centro de uma investigação aderente ao "objeto" para tornar-se motivo de uma evocação pessoal e íntima, destinada a despertar associações mais profundas, escondida sob a superfície das coisas - as "ideias primordiais" das quais falara Moréas (1886) - e que seriam perceptíveis somente pela sensibilidade poética. Recusa-se, assim, o status absolutista que a modernidade confere à ciência e à observação empírica, consideradas pelo pensamento progressista os únicos caminhos para chegar a uma compreensão "verdadeira" do mundo. Na visão dos simbolistas, a ciência não consegue penetrar satisfatoriamente na alma humana e nos mistérios do universo e, por isso, ao poeta e não ao cientista è dada a possibilidade de uma experiência e de um conhecimento privilegiados do real. Este passa a ser comunicado através de uma linguagem que, não mais orientada pela lógica ou pelo rigor clássico, é dotada de grande ambiguidade, comunicada pelo uso de recursos expressivos quais metáfora, analogia e sinestesia, voltadas a captar as relações misteriosas e simultâneas entre as coisas. Na sua posição de intérprete do mundo ao seu redor, o poeta recupera parte do papel que o romantismo lhe conferira, sendo concebido como um visionário capaz de perceber verdades e manifestações da harmonia universal, velada à maioria insensível dos homens.

Neste novo modo de conceber e expressar a realidade

inelutável fim de uma escolta imediatamente anterior" (tradução nossa). 
sensorial, a centralidade ocupada pela subjetividade artística é uma das razões à base da opção, tipicamente decadentista, de conferir ao esteta um lugar privilegiado na escala social. Quando artista, este passa a ser objeto de um de culto semelhante ao dedicado à obra de arte, considerada único fenômeno capaz de redimir o homem de uma existência vazia e fundada sobre a descrença em outros valores superiores da existência. Exemplar é o caso do escritor e "super-homem" Gabriele D’Annunzio. Uma aura mítica circunda a sua figura na sociedade italiana entre os séculos XIX e XX, transformando-o em espécie de "divo" nacional que, de certa forma, precede o culto dedicado mais tarde a Benito Mussolini. O seu primeiro romance, escrito em 1888 e intitulado Il piacere, deixa claro o ideal estetizante da arte como prazer absoluto, incorporado pelo herói decadente Andrea Sperelli." "Corrompido" pelos refinamentos de uma cultura que fortalece a sua sensibilidade estética ao mesmo tempo em que enfraquece a sua força moral, o protagonista apresenta-se dividido entre a idealidade sagrada da arte e a realidade mundana dos sentidos. A sua cura e redenção espiritual pode ser encontrada, então, no equilíbrio entre "un fine epicureismo pratico" e o "culto profondo $e$ appasionato" à suprema musa:

- L'Arte! L'Arte! - Ecco l'Amante fedele, sempre giovine, immortale; ecco la Fonte della gioia pura, vietata alle moltitudini, concessa agli eletti; ecco il prezioso Alimento che fa l'uomo simile a un dio. Come aveva egli potuto bevere ad altre coppe dopo avere accostate le labbra a quell'una? [...]. Come, infine, i suoi sensi avean potuto indebolirsi e pervertirsi nella bassa lussuria dopo essere stati illuminati da una sensibilità che coglieva nelle apparenze le linee invisibili, percepiva l'impercettibile, indovinava i pensieri nascosti della Natura? [grifo nosso] (D'ANNUNZIO, 1995, p. 110). ${ }^{8}$

\footnotetext{
${ }^{7}$ O prazer (tradução nossa).

8 "um fino epicureísmo prático", "culto profundo e apaixonado”; “- A Arte! A Arte!
} 
Transposta ao romance, a oposição entre uma perfeição formal capaz de revelar o invisível e uma realidade carnal que é refúgio ilusório do poeta, atormentado depois pela culpa, reflete a herança do Baudelaire das Flores do mal. Todavia, se no último a tentativa de envolver o leitor - seu "semelhante" e "irmão" - reflete-se na impostação da poesia "su un 'noi' corale indicante la condizione umana” (CACCIAVILLANI, 2000, p. 45), em D’Annunzio se evidencia a concepção exclusivista do esteta, eleito entre os eleitos que, à semelhança de um deus, se embriaga na "Fonte de júbilo" cujo acesso - econômico, inclusive - é proibido às multidões. ${ }^{9}$

Distante dos centros do poder cultural, a posição do simbolista Cruz e Sousa não poderia ser diferente. ${ }^{10} \mathrm{~A}$ arte não é, para o poeta brasileiro e pobre, a materialização da beleza da qual se circunda o homem de posses, mas experiência transcendente que se realiza no contato com uma verdade universal, compreendida através de um percurso doloroso, marginal e solitário, carregado por

- Eis a Amante fiel, sempre jovem, imortal; eis a Fonte do júbilo puro, proibido às multidões, concedido aos eleitos; eis o precioso Alimento que faz o homem semelhante a um deus. Como podia ele ter bebido de outras taças depois de ter aproximado os lábios àquela? [...] Como, enfim, os seus sentidos tinham podido enfraquecer-se e perverter-se na baixa luxúria depois de terem sido iluminados por uma sensibilidade que captava nas aparências as linhas invisíveis, percebia o imperceptível, adivinhava os pensamentos escondidos na natureza?" (tradução nossa).

9 "sobre um 'nós' coral indicador da condição humana" (tradução nossa).

${ }^{10}$ Nascido em 1861, na cidadezinha de Nossa Senhora do Desterro, em Santa Catarina, e falecido em Curral Novo, Minas Gerais, no ano de 1898, João de Cruz e Sousa é um poeta pouco reconhecido em vida. Sua obra seria revista e valorizada por parte da geração modernista e, mais tarde, sobretudo pelos estudiosos interessados na produção literária afro-brasileira, da qual é um dos poucos representantes não mestiços. Entre tais estudiosos, assinala-se Roger Bastide, que a ele dedica quatro estudos em volume sobre a poesia afro-brasileira, publicado no Brasil em 1943. A problemática da identidade racial de Cruz e Sousa em uma sociedade dominada pelo sentimento e pelas teorias da superioridade branca é comentada também por Raymond Sayers em Onze estudos da literatura brasileira (1983). Tanto Bastide quanto Sayers veem ecos do conflito racial nos poemas em que transparece o desejo irrealizado por mulheres brancas (uma virgem sobre um altar eclesiástico que rejeita a adoração de um monstro), assim como no maior realismo de poemas em que trata do amor (possível) por mulheres negras. Em relação a estes e outros estudos sobre Cruz e Sousa, reenviamos às "Notas sobre a literatura brasileira afro-descendente", de Eduardo de Assis Duarte. 
um sentimento de morte e de martírio. Conforme expõe no belo "Iniciado" de Evocações (publicado postumamente, em 1898), é a "via sacra da arte" a conduzir o poeta por "augustos e inéditos Infernos", dando lugar a uma transfiguração em que o jovem viçoso e saudável cede lugar ao ser "lívido, trêmulo, espectral" dotado do aspecto angustiante "de um guilhotinado" (SOUSA, 1898, p. 1415). À experiência estética alia-se, assim, a ideia de condenação à morte, onde esta é ponto de atração e passagem obrigatória para a revelação do mistério da vida, evocado em visões noturnas e fantasmagóricas. ${ }^{11}$

Embora divirjam em mais de um aspecto, decadentismo e simbolismo são movimentos fundamentais por agirem como divisor deáguas entre o romantismo eas vanguardas do século XX, propondo um comportamento antirracionalista, exotérico e refinado, que leva ao extremo o filão simbólico do romantismo (CASADEI; SANTAGATA, 2011). Segundo Bosi (2006), o símbolo assume então a função de vincular as partes ao todo universal. 0 que, observa Bastos (2013, p. 86), se dá num movimento de afastamento de uma simbologia convencional (por exemplo, a cruz para simbolizar a fé; o leão como símbolo de força, etc.), aproximando-se de uma representação simbólica intencionalmente vaga e misteriosa que torna a linguagem "semanticamente imprecisa, com abundância de substantivos abstratos, plurais indeterminadores, emprego ostensivo de maiúsculas alegorizantes, vocabulário composto de palavras pouco comuns". É o caso dos baudelerianos "Benção" e "O albatroz", das Flores do mal, onde os efeitos sonoros e imagéticos potencializam a ideia do poeta enquanto ser maldito e, ao mesmo tempo, bem-aventurado entre os homens. Figura errante e boêmia que encara o sofrimento como possibilidade de libertação interior, condenado e ridicularizado pela turba, o poeta vive a própria solidão em um mundo terreno cuja essência divina só ele é capaz de compreender, e do qual é o único em condições de alçar-se.

${ }_{11}$ Ainda em Evocações, esta ideia se evidencia de forma explícita em "Condenado à morte", condição simbólica do "Estético doloroso" (SOUSA, 2008b, p. 424-428). 
Le Poëte est semblable au prince des nuées

Qui hante la tempête et se rit de l'archer;

Exilé sur le sol au milieu des huées,

Ses ailes de géant l'empéchent de marcher ${ }^{12}$ (BAUDELAIRE, 2005, p. 352)

\section{No Brasil, a direção do movimento}

Surgindo em terras brasileiras antes que em portuguesas, o simbolismo é assimilado aqui por Medeiros e Albuquerque, que em 1887 recebe "de um amigo de Paris" as obras de "Mallarmé, Ghil, Stuart Merril e Jean Moréas", publicando, dois anos mais tarde, Canções da Decadência e Pecados (SAYERS, 1983, p. 54). Caracteristicamente colonial, o mecanismo da recepção é o de atualização em relação às novidades em voga na Europa, o que nos permite afirmar que, também desta vez, é o "influxo externo" a determinar a direção do movimento. ${ }^{13}$ Este se afirma definitivamente com os poemas em prosa de Missal e os poemas em verso de Broquéis, publicados por Cruz e Sousa em 1893. A filiação à escola estrangeira, todavia, não significa mera reprodução de algo já existente. Como observa Eduardo Portela apud Murici:

Cruz e Sousa foi a estilização ou reação brasileira diante de um Simbolismo eminentemente francês. No processo dialético da obra do grande poeta negro está a nota mais tipicamente brasileira de um movimento que era francês. A condição do etnicamente marginal, do "emparedado", agravada pelas suas debilidades físicas, outorgou-lhe uma cosmovisão de tal maneira peculiar que o distancia convenientemente dos seus companheiros franceses (PORTELA apud Murici, 1995, p. 40).

${ }^{12} 0$ Poeta se compara ao príncipe da altura / Que enfrenta os vendavais e ri da seta no ar / Exilado no chão, em meio à turba obscura, / As asas de gigante impedem-no de andar (tradução de Ivan Junqueira).

${ }^{13}$ Faz-se menção, aqui, à citação que Roberto Schwarz (2012, p. 30) faz de Machado de Assis no célebre Nacional por subtração: "Conforme notava Machado de Assis em 1879, 'o influxo externo determina a direção do movimento' “. 
De forma não dessemelhante se expressa Roger Bastide em estudo comparado sobre as poéticas de Baudelaire e Cruz e Sousa:

tanto em prosa como nos versos, nunca Cruz e Sousa desenvolve um tema baudelariano na sua totalidade poética. Ele encerra somente, resvala pelo seu próprio pensamento, introduz numa linha melódica original alguns temas musicais de Baudelaire, que se juntam momentaneamente aos seus, trocam notas e se separam e se desvanecem. Mas exatamente por não se apresentarem nunca sozinhos, por não passarem de flutuantes sobre uma superfície poética estranha, assumem significação bem diversa da que tinham nas Fleurs du Mal (BASTIDE, 1943, p 74).

Pela sua qualidade expressiva, a originalidade melódica a que se refere Bastide deixa fortes impressões no leitor, marcando a tônica particular da poética de Cruz e Sousa. Além das imagens descritas pela palavra, a cadência e a qualidade sonora com que esta é empregada conferem à escrita um movimento musical e rítmico capaz de transmitir uma gama de sensações que, presentes na língua, são valorizadas através de uma acurada pesquisa estilística. Esta tem sua importância esclarecida pelo próprio Cruz e Sousa, que compara o estilo ao "sol da escrita", responsável por coferir à criação poética "todas as gradações da luz, toda a escala dos sons" (SOUSA, 2008, p. 161). ${ }^{14}$ A concretude sensorial com a qual Cruz e Sousa (2008, p. 161) percebe a escrita pode ser identificada nos termos empregados para definir a palavra: possuindo "a sua anatomia" onde estão presentes cor, forma, som e sabor, a sua totalidade só é compreendida por aqueles dotados de "uma rara percepção estética, uma nitidez visual, olfativa, palatal e acústica, apuradíssima". Além disso, entre a palavra e o que esta denomina deve existir uma correspondência, pois a "inteireza da escrita" está no fato de que as "vestes" das palavras estejam em conformidade com o assunto sobre o qual discorrem (concepção que se assemelha

14 Publicado em Outras evocações (1961), o ensaio foi reunido no segundo volume das obras completas do poeta, organizadas por Lauro Junkes, em 2008. 
à estilística antiga, que vê a necessidade de correspondência entre os estilos - alto, médio, baixo - e os gêneros literários, segundo o seu "conteúdo").

Na necessidade de interação entre forma e conteúdo, inscreve-se também o valor transcendente conferido à linguagem artística, elo de ligação entre o poeta e a realidade, fundado no princípio de que a "Arte vem da Natureza, porque um artista faz-se da Natureza" (SOUSA, 2008, p. 161). Esta ideia é explicada melhor em "Luz e treva", onde o autor - em linha com a mística percepção simbolista - afirma que existe um mundo mágico para além das coisas terrenas, imperceptível para o vulgo. No ensaio, fundamental é a ideia da superior sensibilidade do poeta, cuja luz própria faz com que enxergue o que as multidões não veem. Dentro da sua imaginação solitária, ele abriga mundos grandiosos e autônomos, habitados por seres magníficos:

Não sei que luz estranha ilumina os espíritos superiores; eles refletem cousas extraordinárias que os seres vulgares nem sequer percebem, cambiantes de mágico brilho, fulgurações de astros incendidos no céu através a bruma transparente distendida no espaço.

Nessas imaginações esplêndidas, que parecem continuamente mergulhadas numa fosforescência translúcida, há incêndios de sóis, rendilhados jasperinos de espumas, colorações de astros e flores, diafaneidades de gozos indescritíveis; há risos de auroras, prantos de orvalho, rios de lágrimas, céus de alegrias, noites de tristezas, oceanos estrelados de amor, tempestades de ódio, eternidades de agonia; há envergaduras de heróis, reflexos de mulheres divinas, corpos aéreos de criaturas sobre humanas!... Há um mundo, uma natureza além das cousas terrestres superior a todas as cousas, em que vivem deuses fabulosos, arcanjos e sombras, que a vulgaridade não conhece (SOUSA, 2008, p. 208). ${ }^{15}$

Deste ponto de vista, somente o homem talentoso, que olha para dentro de si, seria capaz de captar no próprio pensamento o reflexo

${ }_{15}$ Publicado em Outras evocações (1961), o ensaio foi reunido no segundo volume das obras completas do poeta, organizadas por Lauro Junkes, em 2008. 
das visões extraordinárias que o escritor transporta para a "tela incomparável dos seus quadros fantásticos, luminosos" (SOUSA, 2008, p. 208). Embora o poeta faça questão de assinalar a diferença entre si e o vulgo, a sua postura parece ter pouco em comum com o filão decadentista aqui identificado com o elitismo d'annunziano, onde a distinção social do "gênio" é intimamente atrelada a sua elevada posição econômica. Levando em consideração, inclusive, a posição marginal que Cruz e Sousa ocupa na sociedade brasileira de então, exacerbar o poder sensorial do poeta e a sua distinção do espírito "vulgar", é muito mais um ato de resistência ao poder cultural e econômico que o segrega, que uma separação de tipo classista em relação ao "vulgo".

\section{Luz, sombra e musicalidade}

A importância do elemento visual na poética de Cruz e Sousa é perceptível tanto no título do artigo citado acima - "Luz e treva", que se refazendo ao claro/escuro simboliza o contraste entre a sabedoria e a ignorância -, quanto na imagem de uma transposição da escrita à tela. A analogia entre a imagem grafada em cores e a palavra escrita já comparecia em "O estilo" na afirmação de que o escritor é também o pintor e que, na sua arte, "gradua a luz, tonaliza, esbate e esfuminha os longes da paisagem” (SOUSA, 2008, p. 161). Peça importante no jogo sinestésico travado com o leitor, a alternância claro/escuro como correspondência do binômio visão/ cegueira se evidencia na descrição das trevas em que mergulham as mentes pouco imaginativas:

é que na escuridão vazia e tenebrosa que eles têm em si, nada distinguem, nada compreendem, porque não lhes chameja a imaginação, essa peregrina centelha acendida no cérebro como um grande farol na imensidade, essa luz fertilizante que vê as cousas inauditas que nos deslumbram; é que eles têm dentro do crânio a maldição da treva a esterilizar-lhes a mente, a mergulhá-los na 
sombra implacável do vácuo e do nada! (SOUSA, 2008, p. 208-209).

Como observa Sayers (1983), o sentido proeminente dado à cor na produção literária de Cruz e Sousa evidencia-se na transição do branco - cor dominante em seus primeiros poemas, refletindo a importância da mesma na poesia simbolista - à sempre maior presença do negro, na medida em que suas últimas obras tornam-se mais lúgubres. Bastide (1943, p. 65), por sua vez, pontua que o "simbolismo europeu é essencialmente a apologia do branco", e que Cruz e Sousa toma tal apologia por empréstimo, fixando-se nela como "nostalgia do branco". ${ }^{16}$ Contando as evocações de cores na obra do poeta, Bastide (1943, p. 65) observa que "o azul, o verde, o vermelho, o roxo que representam um certo papel no Missal desaparecem nos Broquéis ( 8 epítetos verdes, 1 roxo...), enquanto o branco em seus diversos tons [...] volta 169 vezes" e, em Faróis, diminui pela metade para dar lugar à poesia noturna.

Aliado à evocação das cores, um dos exemplos mais claros da integração de um princípio simbolista - a valorização da música na construção poética - a aspectos culturais e musicais profundamente brasileiros é dado pelo poema "Violões que choram...", publicado postumamente em Faróis, no ano de 1900. No poema, percebese uma magistral exploração do recurso sonoro enquanto possibilidade expressiva que enriquece o processo de interpretação semântica. Intimamente ligado à cultura popular, o violão "instrumento genuinamente brasileiro", como definiria Policarpo Quaresma no romance de Lima Barreto (1915, p. 19) - ganha sob a lavra de Cruz e Sousa o tom contemporaneamente lamentoso e voluptuoso que seria, mais tarde, a característica marcante de uma das mais conhecidas expressões musicais brasileiras, o chorinho, que começa a ganhar forma em meados do século XIX.

\footnotetext{
${ }^{16}$ Bastide dá uma interpretação racial ao branco, vendo na adesão de Cruz e Sousa ao simbolismo uma tentativa de elevação social dada a partir da sua "nostalgia do branco".
} 
Na poesia, o recurso sonoro adquire máxima amplitude na estrofe:

Vozes veladas, veludosas vozes,

Volúpias dos violões, vozes veladas,

Vagam nos velhos vórtices velozes

Dos ventos, vivas, vãs, vulcanizadas (SOUSA, 1900, p. 59).

Fazendo recurso à fonética, é fácil perceber como a repetição e encadeamento das consoantes vozeadas $[\mathrm{v}]$ e $[\mathrm{z}]$ produzem o efeito de uma vibração contínua que cria uma "base sonora" capaz de "embalar" os versos, em um procedimento semelhante ao da base de violão na música cantada. Como observa Bastos (2004), o conteúdo semântico - os sons do violão e das vozes transportadas pelo vento - ganha imediata expressão na forma poética. Esta realiza-se contemporaneamente enquanto evocação imagética (as palavras descrevem uma situação a ser visualizada pelo leitor) que de certa forma é transportada à realidade sensível através da evocação sonora (as palavras mimetizam rítmica e melodiosamente a situação descrita). No plano das ideias, o princípio simbolista de uma ligação metafísica com o absoluto através da criação artística pode ser percebido nos seguintes versos:

Tudo nas cordas dos violões ecoa

E vibra e se contorce no ar, convulso...

Tudo na noite, tudo clama e voa

Sob a febril agitação de um pulso

Que esses violões nevoentos e tristonhos

São ilhas de degredo atroz, funéreo,

Para onde vão, fatigadas do sonho,

Almas que se abismaram no mistério (SOUSA, 1900, p. 59-60).

Note-se a união do particular com o universal, do artístico com o natural: "tudo" ecoa nas cordas dos violões, transformados nos versos seguintes em ilhas oníricas para onde se dirigem, lançadas 
aos abismos da consciência adormecida, as almas iniciadas no mistério (universal). Obscura nos versos citados, a imagem pode ser clareada pelo autor quando, na sua prosa poética, discorre sobre a noite e, sobretudo, o sonho, entendido como (ir)realidade à base do universo, visível como os elementos físicos que o compõem. Na visão transcendentalista de Cruz e Sousa, tal sonho é despertado tanto na alma inculta quanto na erudita através da obra do artista, nascida de um "movimento de meia inconsciência conceptiva" que intensifica o seu poder de superação do real: "Porque o real é cheio de brumas de sobrenatural, o verdadeiro é cheio de brumas de fantástico e no fundo original da grande Causa está o Sonho" (SOUSA, 1898, p. 162).

A condição transcendente do poeta, cujo espírito transita entre dois mundos (material e imaterial), é expressa também em "Asco e dor", onde Cruz e Sousa relata a sensação de transe vivida diante de uma realidade que pode ser palco de visões sublimes ou infernais. 0 "eu" lírico, situado à hora do crepúsculo no último dia do carnaval, deixa-se arrastar pelo fascínio grotesco de uma mulher que, bêbada e descomposta, oferece à turba inclemente o espetáculo da própria degradação. Comovido e indignado, o poeta oscila entre a empatia e a repugnância por aquela miséria humana. Despertado por sentimentos conflitantes, o seu espírito vaga em uma zona misteriosa, em um estado de semidelírio comparável à atividade do sonhador:

E a minh'alma circunvagava, ia e vinha alucinada, através de adormecidas zonas de sonho, oscilante como um pêndulo de pesadelos, numa aflita ondulação de nevroses, meio dividida entre a bárbara turba mascarada e meio dividida entre a natureza, circundante, cá e lá, guilhotinada misteriosamente pela mesma dor e pelo mesmo asco, cá e lá misturada, amalgamada e perdida em iguais misérias de sangue, lama e lágrimas, ainda e para sempre com o mesmo asco e com a mesma dor...

Ao ato de sonhar alia-se, com frequência, a imagem da noite, que dá título ao ensaio poético onde esta é definida "Hóstia negra dos 
Sonhos brancos que eu eternamente comungo!" (SOUSA, 1898, p. 62). Observe-se, na composição em prosa, um percurso imagético semelhante ao realizado pelo poema "Violões que choram...". Em ambos, as cores brancas e negras configuram os polos de uma tensão estética que traduz o sentimento de dilaceração e que conduz ao movimento da queda: o rumo é o de quem se afasta dos olimpos radiantes para endereçar-se à escuridão dos ínferos, da morte, da lama onde arrasta-se a plebe obscura e degenerada.

No início de "A Noite", por exemplo, o poeta dirige a imaginação do leitor para o alto, tecendo imagens onde figuram céu, estrelas, vento, tempestade, e evocando a atmosfera mágica do ambiente noturno, no qual indica a presença simultânea de elementos lúgubres e paradisíacos associados às cores negra e branca, como se lê a seguir:

Ó doce abismo estrelado, nirvana sonâmbulo, taça negra de aromas quentes, onde eu bebo o elixir do esquecimento e do sonho. Como eu amo todas as tuas majestades, todas as tuas estrelas, todos os teus ventos, todas as tuas tempestades, todas as tuas formas e forças! Como eu sinto os perfumes que vêm das grandes rosas místicas dos teus maios; os eflúvios vibrantes, cândidos e finos dos teus junhos; o grasnar dos teus abutres e o claro bater das asas dos teus anjos! (SOUSA, 1898, p. 58).

Em continuidade, a noite é descrita como entidade materna e estranha, na qual a consciência do poeta voa livre, desaparecendo em meio aos astros dourados, enquanto, na terra, os olhos fitam sombras, os braços e as mãos movimentam-se livres, e os pés erram embriagados pelas trevas onde vibram harpas. A ideia de maternidade, todavia, não se encerra nos sentido de proteção e aconchego, mas abre-se aos aspectos soturnos e boêmios que vão conduzindo ao baixo, revelando-a como ambiente espectral onde aninham-se e perdem-se os noctâmbulos, exemplos extraviados de uma humanidade subalterna e trágica:

Mater dos meios tons e das meias sombras, das silhouettes 
e das nuances; trombeta de Josafá, que fazes caminhar todos os espectros, ressuscitar todos os mortos, máscara irônica de todas as chagas; confessionário de todos os pecados; liberdade de todos os cativos: como eu recordo a galeria subterrânea dos teus mórbidos bêbados, dos teus ladrões cavilosos, das tuas lassas meretrizes, dos teus cegos sublimes e formidáveis, dos teus morféticos obumbrados e monstruosos, dos teus mendigos teratológicos, de aspecto feroz e perigoso de tigres e ursos enjaulados, acorrentados na sua miséria, dos teus errantes e desolados Cains sem esperança e sem perdão, toda a negra boêmia cruel e tormentosa, ultrarromântica e ultratrágica, dos vadios, dos doentes, dos degenerados, dos viciosos e dos vencidos (SOUSA, 1898, p. 62).

Também em "Violões que choram...” existe um movimento descendente, onde a poesia, que inicia com uma imagem noturna iluminada pelo luar, pelas estrelas e pelo "azul da fantasia", vai sendo tingida de negro e ganhando peso. A sensação é de vórtice infernal, de descida, direção característica de toda dessacralização. 0 mistério funesto sobre o qual abismaram-se as almas seguindo os suspiros dos violões, povoa-se logo de caveiras, de sombras mortas, de longos véus de viúva, de velhos e velhas e cegos, concentrandose por um momento no contraste entre o escuro e o claro, expresso pelo "lenço preto" que comprime o queixo do "lívido defunto":

Quanta plebéia castidade obscura

Vegetando e morrendo sobre a lama,

Proliferando sobre a lama impura,

Como em perpétuos turbilhões de chama.

Que procissão sinistra de caveiras,

De espectros, pelas sombras mortas, mudas...

Que montanhas de dor, que cordilheiras

De agonias aspérrimas e agudas.

Véus neblinosos, longos véus de viúvas

Enclausuradas nos ferais desterros,

Errando aos sóis, aos vendavais e às chuvas, 
Sob abóbadas lúgubres de enterros;

Velhinhas quedas e velhinhos quedos, Cegas, cegos, velhinhas e velhinhos, Sepulcros vivos de senis segredos, Eternamente a caminhar sozinhos;

E na expressão de quem se vai sorrindo,

Com as mãos bem juntas e com os pés bem juntos

E um lenço preto o queixo comprimindo,

Passam todos os lívidos defuntos... (SOUSA, 1900, p. 62).

$\mathrm{Na}$ imagem da morte, ligada à da noite, do sono e dos fantasmas, fortalece-se a ideia de uma descida dantesca onde, perdida "la diritta via", o poeta observa a procissão infernal dos vencidos, que buscam no som dos violeiros o alívio momentâneo para as próprias penas:

Ébrios antigos, vagabundos velhos,
Torvos despojos da miséria humana,
Têm nos violões secretos Evangelhos,
Toda a Bíblia fatal da dor insana (SOUSA, 1900, p. 63).

Servindo de efêmera consolação, a menção das escrituras sagradas não arresta a queda. Expressão de uma miséria íntima (o vício) e coletiva (a sua condição marginal e pobre), o desfile grotesco dos "degenerados de todos os sangues" continua o seu percurso descendente. E se a imagem sombria é iluminada ao fim do poema, tal luz advém de um luar da meia-noite, hora simbolicamente conectada ao demoníaco, ao fantasmagórico, ao profano e ao "mundo dos mortos".

\footnotetext{
Todas as ironias suspirantes

Que ondulam no ridículo das vidas, Caricaturas tétricas e errantes

Dos malditos, dos réus, dos suicidas;

Toda essa labiríntica nevrose
} 
Das virgens nos românticos enleios;

Os ocasos do Amor, toda a clorose

Que ocultamente lhes lacera os seios;

Toda a mórbida música plebéia

De requebros de faunos e ondas lascivas;

A langue, mole e morna melopéia

Das valsas alanceadas, convulsivas;

Tudo isso, num grotesco desconforme,

Em ais de dor, em contorsões de açoites,

Revive nos violões, acorda e dorme

Através do luar das meias-noites! (SOUSA, 1900, p. 64).

Formal e semanticamente, o movimento de queda confirma a laceração entre o real (a plebe degenerada no sangue, no vício e na lama) e a sua idealização (a labiríntica nevrose das virgens nos românticos enleios), ambos reforçados pelo contraste entre luz e sombra. Contraste que, no poema, é empregado para produzir efeitos semelhantes aos da técnica do claro-escuro na pintura, intensificando a dramaticidade e a sugestionabilidade da representação. Assim, o ritmo da poesia vem a ser pautado também cromaticamente: os claros e escuros, em sua alternância, orientam a atenção do leitor para ações que, no fundo tenebrosos, são pontual e teatralmente iluminadas, carregando-as de sentimentos de melancolia e de mistério. Aplicado criativamente à realidade brasileira, o procedimento sinestésico configura-se modo a transpor em imagem e som a condição de contemporânea segregação (social) e transcendência (espiritual) do poeta, que vive em meio aos vencidos a própria infernal condição. 


\section{Referências bibliográficas}

BARRETO, L. Triste fim de Policarpo Quaresma. Rio de Janeiro: Typ. Revista dos Tribunaes, 1915. Obra digitalizada pela Biblioteca Brasiliana Guita e José Mindlin. Disponível em <http://www.brasiliana.usp.br/bbd/ handle/1918/00117900>.

BASTIDE, R. Quatro estudos sobre Cruz e Sousa. In: A poesia afro-brasileira. São Paulo: Martins, 1943. P. 87-128.

BASTOS, A. Poesia brasileira e estilos de época. Rio de Janeiro: 7Letras, 2004.

BAUDELAIRE, C. L'Albatros. Tradução Ivan Junqueira. Revista Brasileira, Rio de Janeiro, Ano XI, No 43, p. 352-353, AbrilMaio-Junho 2005. Disponível em http://www.academia.org. br/abl/media/poesia43.pdf . Último acesso em 28-10-2-14.

BAUDELAIRE, C. Bénédiction. Tradução Ivan Junqueira. Revista Brasileira, Rio de Janeiro, Ano XI, No 43, p. 346-351, Abril-Maio-Junho 2005.

BOSI, A. História concisa da literatura brasileira. São Paulo: Cultrix, 2006.

CACCIAVILLANI, G. La malinconia di Baudelaire. Nápoles: Liguori, 2000.

CANDIDO, A. Iniciação à literatura brasileira: Resumo para principiantes. São Paulo: Humanitas, 1997.

CASADEI, A.; SANTAGATA, M. Manuale di letteratura italiana contemporanea. Roma: Laterza, 2011. 
D’ANNUNZIO, G. Il piacere. Roma: Newton Compton, 1995.

DIDIER, B. Petites revues et esprit bohème à la fin du XIXe (1878-1889): Panurge, Le Chat noir, La Vogue, Le Décadent, La Plume. Paris: L'Harmattan, 2009.

DUARTE, E. A. Notas sobre a literatura brasileira Afrodescendente. In: DUARTE, E. A.; SCARPELLI, M. F. (Orgs.). Poéticas da diversidade. Belo Horizonte: UFMG, Fale, 2002. P. 47-61.

JUNKES, L. Simbolismo. São Paulo: Global, 2006. (Coleção roteiro da poesia brasileira).

MANIFESTE littéraire, Un. Le Figaro, Paris, Supplément Litteraire, p. 150, 18 set. 1886. Documento original digitalizado pela Universitat Duisburg-Essen. Disponível em: https://www.uni-due.de/lyriktheorie/scans/1886_moreas. pdf . Acesso em: 15 ago. 2014.

MORÉAS, J. Le symbolism. Le Figaro, Paris, Supplément Littéraire, p. 150-151, 18 set. 1886. Documento original digitalizado pela Universitat Duisburg-Essen. Disponível em: https://www.uni-due.de/lyriktheorie/scans/1886_moreas. pdf . Acesso em: 15 ago. 2014.

MURICI. A. Atualidade de Cruz e Sousa. In: SOUSA, C. Obras completas. Rio de Janeiro: Nova Aguilar, 1995. P. 19-48.

SCHWARZ, R. Nacional por subtração. In: Que horas são? . São Paulo, Companhia das Letras, 1987. P. 29-48.

SOUSA, C. e. A Noite. In: Evocações. Rio de Janeiro: Tip. Aldina, 1898. P. 58-65. Cópia digital disponibilizada Biblioteca Brasiliana da USP. 
SOUSA, C. e. Condenado à morte. In: Evocações. Rio de Janeiro: Tip. Aldina, 1898. P. 69-76. Cópia digital disponibilizada Biblioteca Brasiliana da USP.

SOUSA, C. e. Intuições. In: Evocações. Rio de Janeiro: Tip. Aldina, 1898. P. 154-197. Cópia digital disponibilizada Biblioteca Brasiliana da USP.

SOUSA, C. e. Iniciado. In: Evocações. Rio de Janeiro: Tip. Aldina, 1898. P.13-24. Cópia digital disponibilizada Biblioteca Brasiliana da USP.

SOUSA, C. e. Luz e treva. In: JUNKES, L. (Org.). Cruz e Sousa Obra completa Prosa. Jaraguá do Sul: Avenida ; 2008. v. 2. P. 208-209. Versão digital disponibilizada pela Fundação Catarinense de Cultura.

SOUSA, C. e. 0 estilo. In: JUNKES, L. (Org.). Cruz e Sousa Obra completa Prosa. Jaraguá do Sul: Avenida ; 2008. v. 2. P. 161-163. Versão digital disponibilizada pela Fundação Catarinense de Cultura.

SOUSA, C. e. Violões que choram... . In: Faróis. Rio de Janeiro: Tip. do Instituto Nacional, 1900. P. 58-64. Cópia digital disponibilizada Biblioteca Brasiliana da USP. http://www. brasiliana.usp.br/bbd/handle/1918/00448000. 



\title{
MANOEL DE BARROS É UM LEITOR DOS SERMÕES DE VIEIRA?
}

\section{IS MANOEL DE BARROS A READER OF VIEIRA'S SERMONS?}

\author{
Ilca Vieira de OLIVEIRA ${ }^{1}$
}

\begin{abstract}
RESUMO: Em 2003, o poeta Manoel de Barros inicia a publicação de sua poesia autobiográfica. 0 primeiro livro é intitulado de Memórias Inventadas: a Infância e, logo em seguida, publicará os outros dois livros que completam a trilogia: Memórias Inventadas: a Segunda Infância (2006) e Memórias Inventadas: a Terceira Infância (2008). Este artigo enfoca o leitor que é inventado nessas memórias, em especial um leitor que lê os sermões de Padre Antônio Vieira. Destaca-se, ainda, que, para analisar o leitor que é desenhado na escrita de Manoel de Barros, foram selecionados os poemas: "Parrrede", "Pintura" e "Jubilação", cuja leitura será iluminadapor outros poemas deoutras obras desse poeta.
\end{abstract}

PALAVRAS-CHAVE: Manoel de Barros, memórias inventadas, leitor, sermões de Padre Vieira.

ABSTRACT: In 2003, the poet Manoel de Barros begins

\footnotetext{
${ }^{1}$ Departamento de Comunicação e Letras. Programa de Pós-Graduação em Letras/ Estudos Literários do Centro de Ciências Humanas - Universidade Estadual de Montes Claros (UNIMONTES), campus de Montes Claros - CEP: 39401-089 Montes Claros - MG - Brasil - E-mail: ilca.vieira@pq.cnpq.br e ilcav@uai.com.br. O presente texto foi apresentado como conferência no Seminário de Portugués da Universidade de Salamanca no dia 30/4/2014 e contou com auxílio financeiro do projeto DEG -FAPEMIG. Este estudo faz parte de resultados de pesquisa desenvolvida no projeto "Itinerários Poéticos: viagens, paisagens e imagens das cidades de Minas", financiado pelo CNPq/CAPES/FAPEMIG.
} 
publishing his autobiographical poetry, the first book is titled Invented Memories: Childhood' and thereafter he would publish the other two books that completed the trilogy: Invented Memories: Second Childhood (2006) and Invented Memories: the Third Childhood (2008). This article focuses on the reader who is invented in these memories in particular a reader who reads the sermons of Father António Vieira. It is also noteworthy to mention that to analyze the reader who is drawn in the writing of Manoel de Barros the following poems were selected: "Parrrede", "Pintura" and "Jubilação" and that their reading will be illuminated by other works from this poet.

KEYWORDS: Manoel de Barros, invented memories, reader, FatherVieira's sermons.

\begin{abstract}
Remexo com um pedacinho de arame nas minhas memórias fósseis.

Tem por lá um menino a brincar no terreiro: entre conchas, osso de arara, pedaços de pote, sabugos, asas de caçarolas etc.

[...]

O menino é hoje um homem douto que trata com física quântica.

Mas tem nostalgia das latas.

Tem saudades de puxar por um barbante sujo umas latas tristes.
\end{abstract}

(BARROS, 2001, p. 47).

O livro Memórias Inventadas: as Infâncias de Manoel de Barros, publicado em 2010, reúne em um só livro a série de Memórias Inventadas, a qual é composta pela trilogia: a Infância (2003), a Segunda Infância(2006) e a Terceira Infância (2008), apresentando, também, as iluminuras de Martha Barros, filha do poeta. É importante destacar que cada livro teve sua publicação em uma pequena caixa-livro de papelão rígido, sendo as três impressões realizadas pela mesma editora que publicou, em 2010, a coleção completa dessas "memórias fósseis". O próprio formato do livro já seduz o leitor, por apresentar-se como um presente, ou seja, cada 
um dos livros foi colocado em uma caixa em que se estampam poemas em folhas fixadas com fitas coloridas de cetim.

Essa apresentação do livro em caixa de poemas lembra-nos do que não se joga no lixo, pois, como diz o poeta, no livro Matéria de poesia, de 1970: "0 que é bom para o lixo é bom para a poesia" (BARROS, 2001a, p. 14), ou seja, tudo pode ser "matéria de poesia". Ao publicar as suas Memórias Inventadas, Manoel de Barros traz à tona as suas experiências vividas e experimentadas na infância. Os livros podem ser lidos como uma coleção, e o poeta, como um colecionador. De acordo como Walter Benjamim (2011):

Crianças decretam a renovação da existência por meio de uma prática centuplicada e jamais complicada. Para elas colecionar é apenas um processo de renovação; outros seriam uma pintura de objetos, o recorte de figuras e ainda a decalcomania e assim toda a gama de modos de apropriação infantil, desde o tocar até o dar nome às coisas. Renovar o mundo velho - eis o impulso mais enraizado no colecionador ao adquirir algo novo, e por isso o colecionador de livros velhos está mais próximo da fonte do colecionador que o interessado em novas edições luxuosas. [...] De todas as formas de obter livros, escrevê-los é considerada a mais louvável. (BENJAMIN, 2011, p. 229)

Essas caixinhas de poemas revelam um poeta que "remexe" as suas "memórias fósseis" e retira delas o retrato de um "menino a brincar". Esse menino que sai de dentro dessas caixinhas é um menino que brinca com a língua e que é capaz de "aumentar o mundo/ com as suas metáforas”(BARROS, 2001b, p. 23). Esse menino - inventado nos poemas de Memórias Inventadas - não é novidade para o leitor da poesia da Manoel de Barros, porque ele já figura em Poemas Concebidos sem Pecado, de 1937, como o personagem Cabeludinho. 0 que se pode ler nessa trilogia é que ela se compõe como uma coleção de poemas reunidos em livros: o próprio formato evidencia esse aspecto de sua composição, pois são caixas com fascículos amarelos, presos com fitas. 
Em toda a obra de Manoel de Barros, há vestígios de um poeta colecionador, isto é, tem-se a figura de um sujeito leitor que, ao longo de sua vida, lê e anota, rascunha o que leu, escreve e reescreve os seus poemas. Destaca-se, ainda, em suas composições, o retrato do artista que vai se desenhando em muitos poemas, deixando-se transparecer esse processo de escrita do eu e do outro, nomeandose em vários livros como: diários, retratos, biografia, ensaios fotográficos, compêndios, desenhos, máquina de chilrear, cadernos de apontamentos, etc.

Nota-se que, em vários livros, o poeta explicita o seu diálogo com obras de autores da tradição literária universal ebrasileira ecom a filosofia. Além do diálogo com textos literários e filosóficos, a sua poesia também dialoga com a pintura e amúsica, bem como com outros textos em circulação no momento da escrita e publicação dos livros, tendo como exemplo textos de notícias de jornal.

Nas três caixinhas em que guarda suas memórias, Manoel de Barros inventa um menino leitor e escritor que vai compondo a sua infância por meio da palavra poética "em forma de gosma". $\mathrm{Na}$ primeira caixa, o quarto fascículo amarelo, que é nomeado como "Parrrede", o menino recebe como castigo a leitura dos sermões do Padre Antônio Vieira. Veja-se, a seguir, a transcrição do poema:

Quando eu estudava no colégio, interno, eu fazia pecado solitário.

Um padre me pegou fazendo.

- Corrumbá, no parrrede!

Meu castigo era ficar em pé defronte a uma parede e decorar 50 linhas de um livro.

0 padre me deu pra decorar o Sermão da Sexagésima de Vieira.

- Decorrrar 50 linhas, o padre repetiu.

0 que eu lera por antes naquele colégio eram romances de aventura, mal traduzidos e que me davam tédio.

Ao ler e decorar 50 linhas da Sexagésima fiquei embevecido.

E li o Sermão inteiro. 
Meu Deus, agora eu precisava fazer mais pecado solitário! E fiz de montão.

- Corumbá, no parrrede!

Era a glória.

Eu ia fascinado pra parede.

Desta vez o padre me deu o Sermão do Mandato.

Decorei e li o livro alcandorado.

Aprendi a gostar do equilíbrio sonoro das frases.

Gostar quase até do cheiro das letras.

Fiquei fraco de tanto cometer pecado solitário.

Ficar no parrrede era uma glória.

Tomei um vidro de fortificante e fiquei bom.

A esse tempo também eu aprendi a escutar o silêncio das paredes. (BARROS, 2012, p. 27)

O próprio título do poema já anuncia a escrita desse poeta, o qual afirma, em sua obra, que "escreve com o corpo". É por meio do seu corpo que jorra a semente de sua poética. No livro Arranjos para Assobio, de 1980,o poeta expõe,na sua poesia metalinguística, esse corpo que escreve: "Eu escrevo com o corpo/Poesia não é para compreendermas para incorporar/Entender é parede: procure ser uma árvore" (BARROS, 1998, p. 37).

No início do poema "Parrrede", o poeta faz a seguinte exposição: "Quando eu estudava no colégio, interno, /eu fazia pecado solitário./Um padre me pegou fazendo". (BARROS, 2012, p. 27.Grifo meus). Percebe-se que o passado é recriado por meio de imagens metafóricas. 0 colégio, que representa o espaço no qual se adquirem o conhecimento e o saber, transforma-se em lugar "em que se cometem pecados". É nesse espaço do saber que o menino descobre o prazer do sexo e da leitura. 0 texto nos sugere que o "pecado solitário" é o ato de masturbar-se, e esse ato se transforma numa escrita marcada por vários "r".

No livro Concerto a Céu Aberto para Solos de Ave (1991), Manuel

\footnotetext{
${ }^{2}$ Os poemas citados neste texto de Memórias Inventadas: as Infâncias de Manoel de Barros são de uma edição de 2012, porque esta apresenta páginas, mas, ao longo desta discussão, tomar-se-ão sempre as três caixas com as edições de 2003, 2006 e 2008, a fim de se ilustrar o estudo aqui proposto.
} 
de Barros traz à tona fragmentos da infância do menino no colégio interno. Veja-se, a seguir, o poema:

XXV. (lembrança)

Perto do rio tenho sete anos.

(Penso que o rio me aprimorava.)

Acho vestígios de uma voz de pássaro nas

águas.

Viajo de trem para o Internato.

Vou conversando passarinho pela janela do trem.

Um bedel raspou a cabeça de meu irmão no internato.

Haviaum muro cheio de ofendículos.

Liberdade havia de ser pular aquele muro.

Do outro lado havia um guaviral onde os moços e as moças se encontravam e se filhavam.

A gente manuseava os pichitos.

Na Igreja os padres reuniam os alunos e tentavam falar a sério.

Mas eu sempre achei muita graça quando as

pessoas estão falando sério.

Acho que isso é um defeito alimentar.

(BARROS, 1998c, p.27-28)

No poema acima, do livro de 1991, o poeta já anuncia ao seu leitor o espaço do colégio e a descoberta sexual, o contato com a liberdade e com as proibições dos padres. Esse poema traz elementos que complementam a leitura que se faz do verso "eu fazia pecado solitário". No verso: “- Corrumbá, no parrrede!”, nota-se que há uma repetição da letra " $r$ ", e essa letra revela um som arranhado que pode ser lido como um risco na parede ou o jorro do gozo. O verso: “- Corrumbá, no parrrede!” é escrito pela primeira vez, com alguns "erros" gramaticais, porque as palavras "Corumbá" e "parede"são escritas com três "r". No entanto, é com esse mesmo versoque o leitor irá perceber que o menino parece ter sido corrigido pelos padres que 
apontaram o castigo que lhe era destinado:"decorar o Sermão da Sexagésima/de Vieira".

O que se pode ver nessa cena recriada a partir das Memóriasde Manoel de Barros é que há uma abordagem sobre a leitura do texto literário de língua portuguesanas escolas brasileiras, principalmente no início do século XX. Nota-se que os livros indicados são "romances de aventura/mal traduzidos", como bem destaca esse leitor. Esse texto abre uma reflexão importante sobre a leitura literária no espaço escolar, dando ênfase para os tipos de textos que eram lidos pelos alunos. E o poeta brinca com a língua ao escrever o verso: “- Decorrrar 50 linhas, o padre repetiu”. É possível se ler aí que no espaço escolar a prática de leitura poderia desmotivar o aluno, pois os padres vão colocá-lo de castigo e pedir-lhe para "decorar" o texto literário; ou talvez nos fizesse pensar que há uma crítica aos métodos adotados pelos padres que queriam endireitar esse menino. No entanto, destaca-se que "decorar", pode ser lido como par coeur, relativo ao coração, isto é "aprender de cor", "reter na memória" aquilo que se leu, sendo assim, o menino irá guardar na memória aquilo que ele leu e não irá esquecer os textos de Vieira. As palavras "Decorrrar", "Parrrede" e a frase "Corrumbá, no parrrede!", escritas com tantos "r", pode-se inferir que essas revelam como as palavras eram pronunciadas pelos padres e, ao ouvido do menino, estranhas. 0 que se lê nessa escrita é que o som das palavras que são pronunciadas pelo padre estrangeiro ficou retido na memória da criança e será matéria poética para o adulto que escreve.

A criança é colocada diante da parede para refletir sobre o erro cometido, e o castigo que deveriacorrigi-la é a leitura de um livro. No entanto, há uma descoberta do prazer nas palavras do sermão: "Ao ler e decorar 50 linhas da Sexagésima fiquei/embevecido." Essa descoberta, que se processa com a leitura do sermão,está ligada à descoberta sexual, e, assim, o menino prefere continuar cometendo pecados, para poder ler mais. 0 que o texto evidencia é que, se o professor pretendia castigá-lo com a leitura, nota-se que o efeito é contrário, pois a leitura, supostamente um castigo, passa a ser um 
voo de liberdade. A leitura desse texto pode ser pensada a partir das proposições de Roland Barthes (2002) sobre o prazer do texto que afirma que:

0 escritor de prazer (e o seu leitor) aceita a letra; renunciando à fruição, tem o direito e o poder de dizêla: a letra é o seu prazer; está obsedado por ela, como o estão todos aqueles que amam a linguagem (não a fala), todos os logófilos, escritores, espistológrafos, linguistas; [...] (BARTHES, 2002, p. 29).

0 verso: "Meu castigo era ficar em pé defronte a uma parede e/decorar 50 linhas de um livro." Aqui, como se lê, o castigo do menino é ficar de frente a uma parede. 0 poema "Parrrede" revê a concepção da escrita e da leitura do texto literário. 0 poema de Manoel de Barros demonstra uma ambivalência, sobretudo porque "parede", que se constitui como uma estrutura que é rígida, concreta, e que simboliza prisão do ser humano, passa a ter o sentido de liberdade. A palavra parede, escrita com três "r", anuncia que é necessária a ruptura com a língua gramatical e, nesse sentido, ela liberta o poeta.

Em um poema do livro 0 Guardador de Águas, de 1989, o poeta traz à tona a palavra parede, livre do sentido de negatividade e proibições. Vejase como essa palavra aparece figurada no poema a seguir:

\section{2.}

Que a palavra parede não seja símbolo

de obstáculos à liberdade

nem de desejos reprimidos

nem de proibições na infância

etc. (essas coisas que acham os

reveladores de arcanos mentais)

Não.

Parede que me seduz é de tijolos, adobe preposto ao abdômen de uma casa.

Eu tenho um gosto rasteiro de ir por reentrâncias

baixar em rachaduras de paredes por frinchas, por gretas - com lascívia de hera.

Sobre o tijolo ser um lábio cego.

Tal um verme que iluminasse.

(BARROS, 1998a, p. 51) 
O poeta Manoel de Barros, que se inventa o tempo todo em sua obra, deixa, assim como o fazem o caracol e a lesma, o risco na parede daquilo que sai do seu corpo e da sua língua: as palavras molhadas. Em outro poema desse mesmo livro, $O$ Guardador de Águas, eis um poeta que anuncia o seu desejo de "gosmar/ sobre as palavras". Veja-se, a seguir, o poema:

10.

Em passar sua vagínula sobre as pobres coisas do chão, a lesma deixa risquinhos líquidos...

A lesma influi muito em meu desejo de gosmar sobre as palavras

Neste coito com letras!

$\mathrm{Na}$ áspera secura de uma pedra a lesma esfrega-se

$\mathrm{Na}$ avidez de deserto que é a vida de uma pedra a lesma escorre...

Ela fode a pedra.

Ela precisa desse deserto para viver.

(BARROS, 1998a, p. 49)

$\mathrm{Na}$ escrita desse poeta, há um artista que trabalha a língua e desconstrói o discurso, como ele mesmo destaca no poema "Despalavra", do livro Ensaios Fotográficos, de 2000: "Hoje eu atingi o reino das imagens, o reino da/despalavra" (BARROS, 2001b, p. 23). Esse poeta deixa no papel os rastros de suas palavras que escorrem como lesma na parede. As palavras "Corumbá", "parede" e "decorar" são grafadas com letras a mais do que rege a gramáticae, quando lidas com tantos " $r$ ", provocam em quem lê certa estranheza. Vê-se que a criança comete erros gramaticais que podem ser considerados como deslizes, no entanto, no poema, esses erros e deslizes apontam para a instauração de uma liberdade de criação e invenção.

0 que chama a atenção do leitor, no texto "Parrede", como escrita de memórias do autor, é a cena recriada no colégio. Nela, o poeta reporta-se a um momento de castigo e proibições - cena de violência contra a criança, muito comum em escolas brasileiras, 
durante muitas décadas - e à descoberta da leitura do texto literário. Essa cena não parece ser algo comum nos espaços escolares do nosso país, pois a leitura dos sermões sempre foi vista como difícil, sendo repudiada por muitos leitores. 0 texto, por meio de sua invenção poética, cria a figura do leitor "embevecido" pela escrita dos sermões de Padre Vieira. Então, a leitura, pensada como castigo, passa a ser um ato prazeroso para o menino. Este encontra, nas palavras do "Imperador da língua portuguesa" (PESSOA, s.d, p. 63), um verdadeiro fascínio e diz: "Aprendi a gostar do equilíbrio sonoro das frases./Gostar quase até do cheiro das letras". Essa cena escrita pode ser lida como uma reflexão do adulto sobre a aprendizagem na primeira infância. Seria, também, essa cena escrita uma leitura que o poeta faz do passado, com um olhar mais humanizado?

Ricardo Piglia (2006), no seu texto “O que éum leitor?", ao rastrear a figura do leitor, na literatura, chama esse leitor apaixonado por livros e pela leitura de viciado. De acordo com ele:

O leitor viciado, o que não consegue deixar de ler, e o leitor insone, o que está sempre desperto, são representações extremas do que significa ler um texto, personificações narrativas da complexa presença do leitor na literatura. Eu os chamaria de leitores puros; para eles a leitura não é apenas uma prática, mas uma forma de vida. (PIGLIA, 2006, p. 21)

No caso do leitor figurado no poema "Parrrede", a leitura dos sermões transforma-se em dependência, passando a ser um jogo, pois o menino comete erros para continuar lendo, e essa leitura configura-se, de certo modo, como uma forma de sobrevivência, uma vez que esse sujeito leitor quer se livrar das leituras dos romances, os quais provocam tédio.

Esse poema retoma, também, a escrita da infância, principalmente os erros cometidos no início do aprendizado da língua. Nota-se que o erro é exposto por meio de uma escrita incorreta das palavras e que o poeta adulto brinca com a língua, criando a sua própria Gramática 
Expositiva do Chão, representando, por meio desta, a criança que foi, em suas Memórias Inventadas. Mas, é também esse poeta que "erra a língua" e que esclarece ao seu leitor, em $O$ Guardador de Águas, que: "Para voltar à infância, os poetas precisariam também de/ reaprender a errar a língua./Mas esse é um convite à ignorância? A enfiar o idioma/ nos mosquitos?/Seria uma demência peregrina." (BARROS, 1998a, p. 64)

Na poesia de Manoel de Barros, há um artista que é capaz de "inventar o mundo com as suas metáforas" e, nesse livro de Memórias Inventadas, o leitor poderá perceber que o autorretrato do poeta que se desenha por meio da linguagem poética já vinha sendo elaborado desde o seu primeiro livro, Poemas Concebidos sem Pecados, de 1937. 0 retrato do artista, que pode ser apreendido dessa primeira caixa de poemas, nomeada como a Infância, é de um sujeito que experimenta o prazer da leitura e da escrita, de um poeta que revela, mais uma vez, o que já havia exposto em Retrato do Artista Quando Coisa, de 1998: "Vou sendo incorporado pelas formas pelos/cheiros pelo som pelas cores.” (BARROS, 2001, p. 21).

Ressalte-se que, no Livro sobre o Nada, de 1996, o texto que figura como epígrafe da segunda parte, que é nomeada como "Desejar ser", foi retirado das Paixões Humanas, de Padre Antônio Vieira. E que, além dessa epígrafe, Manoel de Barros compõe, para essa mesma parte desse livro, um poema no qual faz referência implícita ao Sermão dos Peixes. A seguir, cita-se o poema:

13.

Venho de nobres que empobreceram.

Restou-me por fortuna a soberbia.

Com esta doença de grandezas:

Hei de monumentar os insetos!

(Cristo monumentou a Humildade quando beijou os

pés dos seus discípulos.

São Francisco monumentou as aves.

Vieira os peixes.

Shakespeare, o Amor, a Dúvida, os tolos. 
Charles Chaplin monumentou os vagabundos.)

Com esta mania de grandeza:

Hei de monumentar as pobres coisas do chão mijada de orvalho.

(BARROS, 1998b, p. 61)

0 poeta percorre a trajetória histórica, em busca de nomes de grandes homens que foram reconhecidos pelas suas obras, e o Padre Vieira aparece ao lado de figuras como Cristo, São Francisco, Shakespeare e Charles Chaplin. Nota-se que, desde o primeiro verso, há um eu que se coloca como pobre, apesar de reconhecer que herdara umalinhagem poética nobre. Com um teor aparentemente irônico, o poeta traz uma autodefinição do próprio universo de criação, quando se diz herdeiro da "doença de grandezas". Vê-se que há um poeta quequestiona o que é uma grande obra e um grande autor e, contraindo os textos e os autores que cantavam os grandes feitos e os grandes homens da história, apresenta uma lista de poetas que cantaram as coisas pequenas. 0 verso que fecha o poema denota a atividade de atuação poética; há uma autoconfiguração do sujeito lírico que se coloca como grande, por "monumentar as pobres coisas do chão mijada/de orvalho".

No poema, Manoel de Barros revela um lado da escrita de Vieira, com interesse particular para a sua própria poesia, que é o uso de pequenas coisas do chão, nesse caso, precisamente, os peixes. 0 que se pode observar é que essa atração pela escrita de Vieira está presente na poesia Manoel de Barros, mesmo antes de Memórias inventadas, sendo possível reconhecer o uso das imagens metafóricas, das repetições, das hipérboles, das indagações e da forma como seduzia os ouvintes com as palavras, no diálogo com leitor e, pode-se dizer, que a condição de peregrino também possa ter atraído esse poeta. Como destaca n'O Livro das Ignorãças: "Repetir repetir - até ficar diferente/Repetir é um dom de estilo". (BARROS, 2000, p. 11)

O poema, como caixa que guarda lembranças do passado de uma infância vivida e experimentada pela palavra poética, revela 
um artista que se coloca como aquele que inventa o mundo. E, como inventor de sua infância, como leitor dos sermões de Vieira, pode-se observar que o poeta dá outro sentido para o castigo recebido na sua infância: a leitura, como um castigo recebido no colégio interno, não é encenada como sofrimento e dor; ela passa a ser uma experiência importante para se falar do contato com o estético e com o literário. 0 poeta apresenta a leitura como um ato de liberdade que retira o sujeito do emparedamento, ou seja, a escrita liberta o menino-poeta-pássaro. Este alça voo para além dos limites impostos pela língua culta e diz que: “- 0 poeta é promíscuo dos bichos, dos vegetais, das pedras. Sua gramática se apoia em contaminações sintáticas. Ele é contaminado de pássaros, de árvore, de rãs". (BARROS, 1999a, p. 39).

0 poeta revela que aprende com o outro; ao ler o outro, ele vai trazendo a técnica da escrita desse outro para sua própria escrita. E o sujeito embevecido pelos sermões de Vieira, que aparece em "Parrrede", não desaparece de outros textos das Memórias Inventadas, de Manoel de Barros, pois,ao abrir as outras duas caixinhas de poemas, o leitor encontrará maisdois fascículos amarelos: os textos "Pintura" e "Jubilação", em que o escritor Seiscentista é lembrado novamente. A própria forma do texto já sugere ao leitor uma volta à escrita de Vieira, pois essas duas composições têm mais semelhanças com um poema em prosa do que o texto "Parrrede", que se configura em versos. No livro Memórias Inventadas: a Segunda Infância, aparece o segundo texto no qual prevalece um diálogo de Manoel de Barros com a escrita Seiscentista. Veja-se, a seguir, como o poeta se diz aprendiz, em "Pintura":

Sempre compreendo o que faço depois que já fiz. o que sempre faço nem seja uma aplicação de estudos. É sempre uma descoberta. Não é nada procurado. É achado mesmo. Como se andasse num brejo e desse no sapo. Acho que é defeito de nascença isso. Igual como a gente nascesse de 
quatro olhares ou de quatro orelhas. Um dia tentei desenhar as formas da Manhã sem lápis. Já pensou? Por primeiro havia que humanizar a Manhã. Torná-la biológica. Fazê-la mulher. Antesmente eu tentara coisificar as pessoas e humanizar as coisas. Porém humanizar o tempo! Uma parte do tempo? Era dose. Entretanto eu tentei. Pintei sem lápis a Manhã de pernas abertas para o sol. A manhã era mulher e estava de pernas abertas para o sol. Na ocasião eu aprendera em Vieira (Padre Antônio, 1604, Lisboa) eu aprendera que as Imagenspintadas com palavras eram para se ver de ouvir. Então seria o caso de se ouvir a frase pra se enxergar a Manhã de pernas abertas? Estava humanizada essa beleza de tempo. E com os seus passarinhos, e as águas e o sol a fecundar o trecho. Arrisquei fazer isso com a Manhã, na cega. Depois meu avô me ensinou que eu pintara a imagem erótica da Manhã. Isso fora. (BARROS, 2012, p. 85)

Esse poema "Pintura" abre, para o seu leitor, uma reflexão sobre o próprio ato de criação literária como invenção. 0 poeta já ressalta, no início do poema, que o processo de composição poética é uma "descoberta" e que a criação do poema não está ligada ao "estudo", como se pode ler no verso: "É sempre uma descoberta. Não é nada/ procurado. É achado mesmo. Como se andasse num/ brejo e desse no sapo". (BARROS, 2012, p. 85). Dessa forma, a criação dos poemas seria algo que surge de maneira espontânea para ele, e não como elaboração técnica. No entanto, o poeta revela as suas contradições, pois, em vários poemas, confirma que a criação literária está relacionada a uma prática de leitura, de escrita e de reescrita constantes. Mesmo nesse texto, pode-se ver que ele confirma que a escrita está relacionada à leitura e aprendizagem, como se pode ler a seguir: "Na ocasião eu aprendera em Vieira (Padre/Antônio, 1604, Lisboa) eu aprendera que as/imagens pintadas com palavras eram para se ver de/ouvir". (grifos meus) (BARROS, 2012, p. 85). 
Se esse poema trata das memórias da infância, não se pode esquecer que a criança inventa o seu mundo por meio de desenhos, de jogos e de brincadeiras. É esse menino, o qual desenha o mundo com a imaginação, que o poeta recupera do passado, fazendo surgir diante dos olhos do leitor um poeta pintor, que desenha as coisas por meio das "cores das vogais" (RIMBAUD, 2007) e que deseja exprimir o inexprimível por meio das imagens metafóricas.

Note-se que, no poema, há um eu que exterioriza as suas dúvidas sobre o processo criativo, por meio de algumas perguntas que são feitas a um suposto leitor, mas esse ouvinte não tem tempo de respondê-las, já que o texto cuidará de dar as respostas ao seu leitor. É possível ler, nas indagações que figuram no texto, que, sem dúvida, o poeta Manoel de Barros recuperou no seu texto a técnica utilizada por Vieira, nos sermões.

Nas indagações do poeta sobre o ato criativo, vê-se que ele sentese impotente diante das palavras. 0 texto explicita uma concepção de poesia como artifício e invenção, deixando exposto o que o poeta descobre: que é possível inventar o mundo com criatividade quando se tem o olhar da criança que brinca. 0 poeta assume o ofício de pintor sem tintas, confirmando ter aprendido com Vieira a técnica de criar as suas imagens metafóricas. 0 poema encena um momento de descoberta, havendo um retorno à infância quando o poeta se configura como alguém que "desenha". No entanto, passado e presente se entrecruzam nessa escrita autobiográfica. E a criança que desenhava o mundo com o seu lápis de colorir vai desaparecer, para dar lugar ao poeta que desenha o seu mundo com imagens metafóricas, e/ou vice-versa. A invenção do mundo pela linguagem metafórica se faz por meio da exploração de todos os sentidos, de forma que corpo eescrita se entrelaçam eroticamente.

Em 17 de dezembro de 2000, Manoel de Barros concede ao Jornal do Brasil uma entrevista, expondo sobre o ato de criar e o ofício de ser poeta. Ao ser indagado por Pedro Maciel acerca da arte de criação poética, ele faz a seguinte exposição: 
- Poesia é devaneio com método?

- Quando um homem se aperfeiçoa para pássaro, ele está querendo ser poeta. Mas para ser poeta ele precisa adquirir o terceiro olho. Aprendi com Sófocles que há três olhos: o divinatório de Tirésias; o olho dos conhecimentos e, por fim, o olho da arte que é o terceiro. Portanto, a arte, que é o terceiro olho, se faz com o sentido divinatório e os nossos conhecimentos. Não basta aperfeiçoar-se em pássaro para cantar. É preciso imprimir no canto uma arquitetura humana. 0 método. Poesia não é devaneio, ora pois. É trabalho com palavras. (BARROS, 2000a)

O que fica evidente para o leitor dessa entrevista é que o poeta é esse ente que possui o terceiro olho, que é o olho da arte. Vê-se que, no poema "Pintura" das Memórias Inventadas, o poeta é um ser que possui um:"defeito de/ nascença isso. Igual como a gente nascesse de/ quarto olhares ou de quatro orelhas". (BARROS, 2012, p. 85). O que o poema sugere é que o poeta precisa de "quatro olhares" para criar o mundo poético, ou seja, o quarto olho seria o olhar da criança. É pelas imagens táteis, visuais, olfativas, gustativas e térmicas que o poeta re-experimenta as experiências vividas no passado, despertando os muitos "eus" vividos, numa alquimia de imagens de espaços e tempos diferentes.

O poema também sugere ao seu leitor uma reflexão filosófica sobre o poeta como um pintor e sobre a poesia como pintura, como se pode ler desde o título. É importante destacar que, desde a Antiguidade, a poesia era entendida e praticada como uma pintura. Na sua Poética, ao definir os vários processos de imitação, Aristóteles faz o seguinte comentário:

Imitador, como o pintor ou qualquer outro artista plástico, o poeta necessariamente imita sempre por uma de três maneiras: ou reproduz os originais tais como eram ou são, ou como os dizem e eles parecem, ou como deviam ser. Isso se exprime numa linguagem em que há termos raros, metáforas e muitas modificações de palavras, pois consentimos isso aos poetas. (ARISTÓTELES, 1997, p. 48) 
Mas é a partir de Horácio e de sua grande popularidade no Classicismo e Neoclassicismo que a comparação se divulga, até se transformar em preceito: "- Pintores e poetas sempre assistiram a justa liberdade de ousar seja o que for. - Bem o sei; essa licença nós pedimos e damos mutuamente; não, porém, a de reunir animais mansos com feras, emparelhar cobras com passarinhos, cordeiros com tigres". (HORÁCIO, 1997, p.55). Como se vê na citação de Horácio, o objetivo do poeta latino era reivindicar para a poesia a mesma liberdade da pintura. Mas não foi assim que o Renascimento e o Barroco entenderam-nas, decretando diferenças entre as duas artes, no que tangia à matéria e ao modo de imitação. Os artistas Miguel Ângelo e Leonardo da Vinci reafirmaram a ligação entre a poesia e a pintura, mas colocaram a pintura acima de todas as outras artes.

Nessa mesma entrevista concedida ao Jornal do Brasil, em dezembro de 2000, o próprio entrevistador Pedro Maciel traz à tona uma pergunta sobre Vieira. Leia-se fragmento, a seguir:

- O padre Vieira diz que "eu preciso de tempo pra ser breve".

- Vieira lisonjeava as palavras para obter favores régios delas. Esse paradoxo é um presente régio que o padre ganhou por ter passado a vida a lisonjear palavras. Acho que Vieira limpava a sua prosa ao ponto de poesia. Essa frase é poética por todas as ressonâncias literais e semânticas. Todos nós precisamos de tempo para enxugar as frases. Dizer a eternidade em duas palavras é uma eternidade em duas palavras. (BARROS, 2000a).

No poema "Jubilação", que aparece em Memórias Inventadas: a Terceira Infância, o poeta retoma o comentário que fizera sobre Vieira no fragmento acima. Na composição poética, ele vai dar continuidade a alguns temas jáexpostos em "Parrrede" e "Pintura", tais como: a criança e as experiências vividas, o menino que brinca e o leitor adulto, o brincar e o escrever, o desenhar e a arte de inventar e reflexões sobre a criação poética. 
Ao se lerem os poemas as Memórias e a entrevista de Manoel de Barros, pode-se ver que a escrita de Vieira assume um lugar de destaque na formação humanística e poética desse escritor. Cita-se, a seguir, "Jubilação":

Tenho gosto de lisonjear as palavras ao modo que o Padre Vieira lisonjeava. Seria uma técnica literária do Vieira? É visto que as palavras lisonjeadas se enverdeciam para ele. Eu uso essa técnica. Eu lisonjeio as palavras. E elas até me inventam. E elas se mostram faceiras para mim. Na faceirice as palavras me oferecem todos os seus lados. Então a gente sai a vadiar com elas por todos os cantos do idioma. Ficamos a brincar brincadeiras e brincadeiras. Porque a gente não queria informar acontecimentos. Nem contar episódios. Nem fazer histórias. A gente só gostasse de fazer de conta. De inventar coisas que aumentassem o nada. A gente não gostasse de fazer nada que não fosse brinquedo. Essas vadiagens pelos recantos do idioma seriam só para fazer jubilação com as palavras. Tirar delas algum motivo de alegria. Uma alegria de não informar nada de nada. Seria qualquer coisa como conversa no chão entre dois passarinhos a catar perninhas de moscas. Qualquer coisa como jogar amarelinha nas calçadas. Qualquer coisa como correr em cavalo de pau. Essas coisas. Pura jubilação sem compromissos. As palavras mais faceiras gostam de inventar travessuras. Uma delas propôs que ficássemos de horizonte para os pássaros. E os pássaros voariam sobre o nosso azul. Eu tentei me horizontar às andorinhas. $\mathrm{E}$ as palavras mais faceiras queriam se enluarar sobre os rios. Se ficassem prateadas sobre os rios falavam que os peixinhos viriam beijá-las. A gente brincava no prateado das águas. A mais pura Jubilação!

(BARROS, 2012, p. 155)

Em "Jubilação", o poeta retoma não só a entrevista dada ao Jornal do Brasil, mas também o poema "Lutador", do livro José, de Carlos Drummond de Andrade (2002). Se o poema de Drummond expressa 
a luta do poeta com as palavras, em Manoel de Barros não ocorre o mesmo, pois o poeta de Corumbá não se sente impotente ante as palavras, porque ele é capaz de lisonjeá-las, deixando explícito como conseguiu domá-las: "lisonjear as palavras ao modo que o/ Padre Vieira lisonjeava. Seria uma técnica literária/do Vieira? É visto que as palavras lisonjeadas se/ enverdeciam para ele. Eu uso essa técnica". O poeta aprendeu a manejar a palavra, explorando o que ela tem de mais sutil e astuto, assim como o fazia Vieira. A relação que o poeta Manoel de Barros estabelece com as palavras não é de lutador, como em Drummond, mas de galanteador, que procura entreter(-se) por meio delas.

O poema, novamente, ressalta, já no título, o modo como o poeta qualifica a sua concepção de poesia, ou seja, poesia como "alegria", sendo a sua prática artística uma técnica herdada de Vieira. 0 poeta se apropria da tradição, devorando a linguagem do outro como um leitor embevecido, aspecto assumido pelo personagem do poema "Parrrede". Evocando a escrita do escritor Seiscentista, o poeta traz uma definição da escrita autobiográfica como um jogo: "Eu/ lisonjeio as palavras. E elas até me inventam. E elas/se mostram faceiras para mim. Na faceirice as palavras/me oferecem todos os seus lados".

A figura do andarilho, tão presente na poesia de Manoel de Barros, aparece também nesse poema, como se pode perceber por meio dos versos: "Então a gente sai/a vadiar com elas por todos os cantos do idioma". No poema há um jogo erótico que se configura, tem-se um poeta que, ao "sair para vadiar com as palavras", obtém "alegria", ou seja, ao errar a língua, ele atinge algo pleno: o gozo com as letras.

Esse poema também retoma a infância, com as brincadeiras e o entrecruzar do passado e do presente: de um lado, figura a infância alegre de um menino que descobre o mundo por meio das brincadeiras, e as palavras inventam esse mundo mágico da infância vivida e experimentada por um adulto que volta a ser criança, com o objetivo de viver novamente o passado. E, de outro, 
figura o escritor adulto que escreve as suas Memórias e faz uma reflexão sobre o próprio processo de composição. Tem-se um poeta erudito, mas conhecedor de que, para chegar à perfeição, é preciso trabalhar a palavra poética, sendo o seu aprimoramento atingido com o passar do tempo.

Esse poeta que "Deseja ser", isto é, que deseja chegar à perfeição da composição poética, aprende com Vieira esse "aperfeiçoar para pássaro", ou seja, é preciso tempo para trabalhar as palavras. E o poeta assume mais um ofício em sua escrita, que é o de escovador de palavras, como se pode ler em "Escova”, poema que abre o livro de Memórias Inventadas: a Primeira Infância:

[...] Logo pensei de escovar palavra. Porque eu havia lido em algum lugar que as palavras eram conchas de clamores [antigos.

Eu queria ir atrás dos clamores antigos que estariam guardados dentro

das palavras. Eu já sabia também que as palavras possuem no corpo

muitas oralidades remontadas e muitas significâncias remontadas. Eu

queria então escovar as palavras para escutar o primeiro esgar de cada

uma. Para escutar os primeiros sons, mesmo que ainda bígrafos.

Comecei a fazer isso sentado em minha escrivaninha. Passava horas inteiras, dias inteiros fechado no quarto, trancado, a escovar palavras.

Logo a turma perguntou: o que eu fazia o dia inteiro trancado naquele quarto? Eu respondi a eles, meio entressonhado, que eu estava escovando palavras. Eles acharam que não batia bem. Então eu joguei a escova fora. (BARROS, 2012, p. 15)

Para encerrar a discussão proposta neste texto, deve-se atentar, também, para um texto escrito por Manuel de Barros e enviado a 
Lúcia Castelo Branco, em dezembro de 2000, o qual foi publicado pela Editora da UFMG em 2009. Nas palavras de Manoel de Barros para a amiga Lúcia, nota-se que Vieira assume um papel importante para esse poeta que escreve desde o século XX até a atualidade. Veja-se, a seguir, a confissão que ele faz à amiga:

\section{COISAS QUE CAEM DO CÉU:}

Pois Pois

Padre Antonio Vieira pregava encostar as orelhas na boca do bárbaro. Para ouvir as vozes do chão e das águas. Para ouvir a voz do silêncio e das pedras. Para ouvir a voz dos passarinhos e das árvores. Pois. Bernardo da Mata, meu irmão de vida e de infância, não fez outra coisa em toda a existência do que encostar o ouvido na boca do bárbaro. Ouviu a voz dos ventos e do sol. Pois. Passei muitos anos rabiscando de noite em meus caderninhos as coisas que Bernardo ouvia e me contava. Penso que ele ouvia mesmo a voz das águas e do chão. Ouvia a voz das origens e as origens da voz. Recolhi alguns de seus escutamentos. Registrei alguns. Se eu tivesse tempo gostaria de compor um livro com tais escutamentos. Dou um exemplo: Acima de mim só Deus e os passarinhos. (BARROS, 2009, p. 74)

Ao terminar esta leitura, fica a pergunta sobre o texto acima, escrito para Lúcia Castelo Branco: o poeta já não estaria anunciando os livros de Memórias Inventadas, que seriam publicados em 2003, 2006 e 2008? Parece ser possível fazer essa inferência, pois o tempo não foi problema para ele.

Em Memórias Inventadas, de Manoel de Barros, pode-se tanto associar a escritura e a leitura à coleção quanto caracterizar o escritor como um colecionador, porque, nos poemas, elabora-se a grafia da vida de um poeta que escreve desde 1937 até a atualidade, contribuindo de maneira significativa para a poesia moderna brasileira. 0 que se pode perceber é que o poeta vai aprimorando o seu retrato de artista, ao longo de sua escrita poética. E, como um leitor, ele sabe ler muito bem o texto do outro, sabe escolher o 
que ler e aprimora a sua escrita todos os dias, como um artista que "Deseja ser".

\section{Referências Bibliográficas}

ANDRADE, C. D. de. José (1942). In: Poesia Completa. Rio de Janeiro: Nova Aguilar, 2002.

ARISTÓTELES. Arte Poética. In: ARISTÓTELES; HORÁCIO; LONGINO. A Poética Clássica. Introdução de Roberto de Oliveira Brandão; tradução de Jaime Bruna. São Paulo: Cultrix, 1997. p. 19-52.

HORÁCIO. Arte Poética. In: ARISTÓTELES; HORÁCIO; LONGINO. A Poética Clássica. Introdução de Roberto de Oliveira Brandão; tradução de Jaime Bruna. São Paulo: Cultrix, 1997.p. 53-68.

BARTHES, R. 0 Prazer do Texto. Trad. de J. Guinsburg. 3. ed. São Paulo: Perspectiva, 2002.

BARROS, M. de. Poemas Concebidos sem Pecado (1937). 3. ed.Rio de Janeiro: Record, 1999.

. Gramática expositiva do Chão (1966). 3.ed. Rio de Janeiro: Record, 1999a.

Arranjos para Assobio (1980). 2. ed.Rio de Janeiro: Record, 1998.

O Guardador de Águas (1989). 2.ed. Rio de Janeiro: Record, 1998a. 
BARROS, M. de. Livro sobre Nada (1996). 7.ed. Rio de Janeiro: Record, 1998b.

. Concerto a Céu Aberto para Solos de Ave (1991). 3. ed. Rio de Janeiro: Record, 1998c.

. Livro das Ignorãças (1993). 9.ed. Rio de Janeiro: Record, 2000.

. Deslimite da Poesia. Entrevista Pedro Maciel. In: Jornal do Brasil, Rio de Janeiro, 17 dez. 2000a.

. Retrato do Artista Quando Coisa. 2. ed. Rio de Janeiro: Record, 2001.

. Matéria de Poesia. 5 ed. Rio de Janeiro: Record, 2001a.

.Ensaios Fotográficos(2000). 3.ed. Rio de Janeiro: Record, 2001b.

. Manoel de Barros/Prólogo Lúcia Castelo Branco. Ilustrações de Maria José Vargas Boaventura. Belo Horizonte: Editora UFMG, 2009. (Coleção AmorÍmpar. Caderno 1)

Memórias Inventadas: as Infâncias de Manoel de Barros. Iluminuras de Martha Barros. São Paulo: Editora Planeta, 2012.

- Memórias Inventadas: a Infância. Iluminuras de Martha Barros. São Paulo: Editora Planeta, 2003.

Memórias Inventadas: a Segunda Infância. Iluminuras de Martha Barros. São Paulo: Editora Planeta, 2006. 
BARROS, M. de. Memórias Inventadas: a Terceira Infância. Iluminuras de Martha Barros. São Paulo: Editora Planeta, 2008.

BENJAMIN, W. Imagens do Pensamento. In: .Obras escolhidas. Trad. de Rubens Rodrigues Torres Filho e José Carlos Martins Barbosa. São Paulo: Brasiliense, 2011. p.227235. v.II: Rua de mão única.

PESSOA, F. Mensagem. In: O Eu Profundo e os Outros Eus. Rio de Janeiro: Nova Fronteira, s/d.

PIGLIA, R. O que é um Leitor? In: 0 Último Leitor. Tradução de Heloisa Jahn. São Paulo: Companhia das Letras, 2006.

RIMBAUD, A. Uma Temporada no Inferno. Tradução de Paulo Hecker Filho. 2. ed. Porto Alegre: L\&PM, 2007.

VIEIRA, A. Sermões. 14. ed. Rio de Janeiro: Agir, 1997. 


\section{SUJEITO EM TRÂNSITO: FILIAÇÃO E RUPTURA AO MODERNISMO EM ARMANDO FREITAS FILHO}

\section{SUBJECT IN TRANSITION: AFFILIATION AND RUPTURE WITH MODERNISM IN ARMANDO FREITAS FILHO'S POETRY}

Paulo ANDRADE ${ }^{1}$

RESUMO: A poesia contemporânea revela identificação com os modernistas. Se esta afinidade se revela, muitas vezes, como "retradicionalização" (SIMON, 2011), em que os poetas fazem uso de formas, técnicas e procedimentos de modo conciliatório, evidenciando uma leitura mais de homenagem do que de crítica, em outros casos, porém, o diálogo se reveza entre convergências e conflitos com as poéticas de mestres como João Cabral, Carlos Drummond, Manuel Bandeira, entre outros. Armando Freitas Filho insere-se nesta segunda tendência da poesia brasileira, formada por poetas que buscam se libertar da tradição para trilhar um caminho singular. João Cabral é um dos principais poetas com os quais Armando Freitas Filho estabelece uma relação de permanente tensão. Se a relação entre Armando e Cabral se dá por meio da desleitura, do desvio, marcando sua filiação, pela diferença, os poemas dedicados a Drummond, publicados em Numeral/Nominal (2003), reveza entre

\footnotetext{
${ }^{1}$ Departamento de Literatura e Programa de Pós-Graduação em Estudos Literários, Faculdade de Ciências e Letras - Universidade Estadual Paulista - UNESP - CEP 14800-901 - Araraquara - SP - Brasil - pauloandrade@fclar.unesp.br
} 
um desejo de rivalizar com ele e com a impossibilidade de alcançá-lo.

PALAVRAS-CHAVE: tradição; intertextualidade; metalinguagem; Armando Freitas Filho; Carlos Drummond de Andrade

ABSTRACT: Contemporary poetry often presents identification with the Modernists and this affinity in many cases can reveal a "retraditionalization" (SIMON, 2011) in which the poets use forms, techniques and procedures in a conciliatory mode, through which their texts become rather tribute readings than critical works. However, in other cases, the dialogue interchanges between convergences and conflicts with the poetic works of masters such as João Cabral, Carlos Drummond de Andrade, Manuel Bandeira, among others. In this sense, Armando Freitas Filho integrates the second trend of Brazilian poetry, formed by poets who seek freedom from tradition so that they can trail a peculiar path. João Cabral is one of the major poets with whom Armando Freitas Filho establishes a relation of permanent tension. If the connection between Armando and Cabral is given by means of un-reading and deviation - determining their affiliation by difference -, on the other hand, the poems dedicated to Drummond published in Numeral/Nominal (2003) simultaneously displays an urge to compete with the poet and the impossibility of reaching him in terms of creative writing.

KEYWORDS: Tradition; intertextuality; metalanguage; Armando Freitas Filho; Carlos Drummond de Andrade.

"Você precisa se deixar inocular pelos poetas que te falam boca a boca. Só sendo possuído por eles vai poder fabricar anticorpos para, pelo menos, encará-los, sem deixar baixar os olhos, mesmo daqui do rés-dochão, como é o meu caso. Se não for assim você ficará paralisado, sem reação. E por mais pífia que seja essa reação, você tem que tentá-la, não uma vez, mas sempre, até o seu último dia" (FREITAS FILHO, 2000, p. 7 
"Se pudesse escolher, preferiria uma estrada mais calma e não esta - pedregosa - que Carlos Drummond abriu para todo sempre, para todos nós" (Id.ibid. p. 11)

$\mathrm{Na}$ contramão de algumas tendências na produção poética brasileira a partir dos anos 90, como a escrita minimalista e antidiscursiva, a ultraespecialização da linguagem com suas imagens raras e sublimes e o diálogo com o cânone modernista, a poesia de Armando Freitas Filho vem perfazendo um percurso cada vez mais singular, sem deixar, no entanto, de manter uma relação de permanente tensão com os seus mestres fundamentais. Um dos aspectos marcantes na obra de Armando Freitas Filho é a representação do ato de escrita. Para Rosa Maria Martelo (2010), a tematização do ato de escrita não é ingênua, nem destituída de sentido, mas, ao contrário, indicia "uma poética e também uma ética da escrita" (MARTELO, p.323), marcando, por meio do gesto metalingüístico, uma reflexão crítica do ato da sua própria escrita. O como se escreve é questão central na poesia de Armando. Neste artigo, iremos mostrar duas funções dessas encenações de escrita: a) marcar posição contra João Cabral, na obra Fio Terra (2000); b) assumir uma postura cambiante entre o desejo de rivalizar com Carlos Drummond e a consciência da impossibilidade de alcançálo, na sequência de poemas, em homenagem ao poeta mineiro, em Numeral/Nominal (2003).

O gesto metalinguístico que, diga-se, não é um fenômeno contemporâneo, exerce papel fundamental na reflexão sobre a sua poética, revelendo procedimentos e formas. Como ilumina Martelo (2010, p.323), "faz parte da dimensão meta-reflexiva da poesia de tradição moderna a apropriação das cenas de escrita como um dos tópicos através dos quais a poesia se dobra sobre si mesma e a si mesma se mostra, pensa e analisa. No gesto de debruçar-se sobre si mesma, a poética de Freitas Filho deixa-se ver e assume sua filiação, marcando uma considerável diferença, em relação aos mestres modernistas, especialmente Cabral e Drummond. 
Em entrevista, Armando comenta a gênese de Fio terra. 0 livro surgiu quando o poeta ganhou um caderno de capa dura e passou a escrever diariamente durante três meses uma espécie de diário poético. Em certo momento decidiu então reescrevê-lo, dando-lhe a conformação atual, com 450 versos: "Fio Terra foi se articulando... da mão para a boca. Contrariando toda a minha 'psicologia da composição' (...) A poesia, quando não é homérica, quando é apenas lírica, te visita brevemente, sem avisar, e vai embora, sem se despedir". (NAVAS, 2000, p. 7-8).

A encenação, no sentido teatral, sobre a escrita poética, começa no próprio título, “3 V 98”, um suposto registro da data de um diário confessional, em que o sujeito reflete sobre a criação poética. Neste jogo, importam o onde escrever - o cenário criado para sustentar no tempo e espaço a captação do instante em que se inicia a escrita - e o como escrever, que se refere à reflexão sobre o ato de escrita:

\author{
Começa o dia e o caderno \\ ainda de dentro, por entre \\ as venezianas que listram \\ de sol e sombra, a folha \\ agora pautada, e sob a mão \\ Mas o que consegue ser escrito \\ na linha que a luz abre \\ não é tudo nem bastante \\ 0 que ficou atrás, no escuro \\ do rascunho, cego e rasurado \\ não pára, de irradiar - segrega \\ em código na entrelinha, o que só \\ passa através de frestas: \\ sussurro, perigo, perfume. \\ Embora adiado, insiste \\ em inscrever-se, intenso. \\ Senão com as palavras \\ com as sensações dos sentidos. \\ (FREITAS FILHO, 2000, p. 567)
}

As categorias positivas que transbordam no ambiente solar não se coadunam com a interioridade angustiante do eu lírico. A luz 
exterior que invade o espaço da intimidade não atinge o sujeito; não lhe possibilita clareza de pensamento, nem lhe possibilita projetar para a folha de papel, com clareza e exatidão, o que pretende dizer. Ao contrário, depara-se com situação de limite, de impossibilidade de transformar em linguagem corpórea o que está guardado no "caderno de dentro". Como dizer aquilo que quer dizer? Como dar materialidade à linguagem, de modo lúcido, nas pautas do "caderno de fora"?

Apesar do poema-diário marcar a passagem do tempo, nos títulos e nas datas à margem do livro, ao longo dos 450 versos, não há, no entanto, marcação da temporalidade. 0 tempo não introduz modificações. O sentido chega aos poucos, de modo nebuloso, desmedido de regras, pronto a revelar o que o "caderno de dentro" pretende exprimir.

Nessa tematização da escrita, o que está em jogo é menos a configuração que a afirmação de uma poética que, no ato da sua realização, já antecipa o seu fracasso. Por isso, é refratária à linguagem controlada e calculada, afinal "o que consegue ser escrito" "não é tudo nem o bastante". A escrita de Armando se mostra como um retorno do recalcado ou como uma escrita em palimpsesto, cujas marcas do rascunho, daquilo que foi apagado, ainda se revela. Por mais que se tente controlar o discurso, alguns elementos ("sussurro, perigo, perfume") insistem em aparecer. 0 que foi recalcado quer "inscrever-se", de modo deformado, "senão for com palavras" ao menos com as "sensações do sentidos"

O que está subjacente nesta poética é a negação do controle da sintaxe de João Cabral, mais precisamente o modelo de "Psicologia da Composição", poema metalinguístico que integra a trilogia publicada em 1947, Psicologia da composição, Fábula de Anfion e Antiode, e que reflete sobre o exercício de criação poética:

Esta folha branca me proscreve o sonho, 


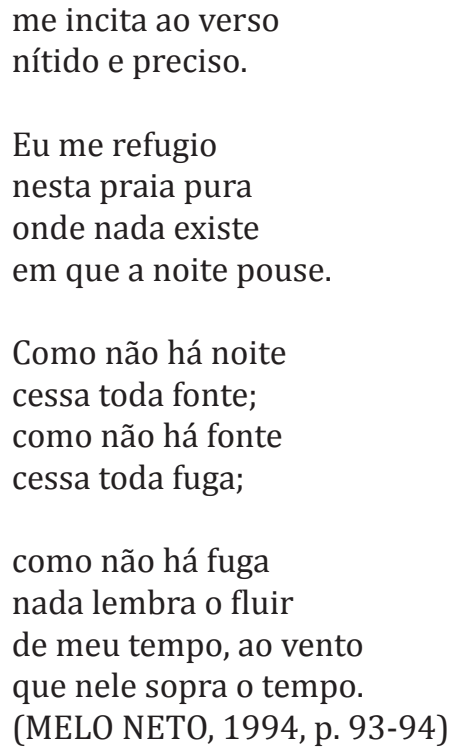

A voz que anuncia o primeiro verso é assertiva e confiante, pois tem a certeza do êxito em sua realização: "Saio do meu poema/ como quem lava as mãos.". 0 sujeito celebra a vitória da composição sobre o branco da folha, do intelecto sobre o sonho. Vence a habilidade técnica que atinge a forma pretendida, não porque foi "encontrada" ou obtida como um milagre ("em lance santo ou raro"), mas atingida pelo labor e atenção cerrada.

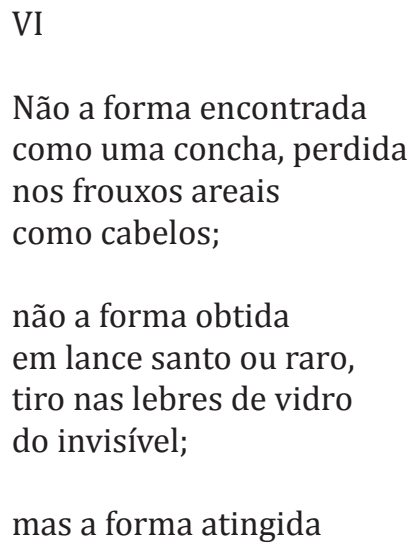


como a ponta do novelo

que a atenção, lenta,

desenrola,

aranha; como o mais extremo

desse fio frágil, que se rompe

ao peso, sempre, das mãos

enormes.

(MELO NETO, 1994, p. 95-96)

A representação do ato de escrita cabralina aponta para uma poética do controle sintático, por meio de versos "nítidos e precisos", e para uma habilidade técnica de tecer o verso, os fios frágeis, tal uma aranha, com extrema meticulosidade. No universo cabralino, tudo o que precisa dizer está dito. Nenhum recalque, "sussurro" que ficou no rascunho segrega ou quer inscrever-se. Esta poética vai ao encontro do pensamento crítico de Wimssat e M. Beardsley (1954), segundo o qual o êxito de um poema está em sua eficácia, em sua capacidade de funcionamento, como se exige de uma máquina qualquer.

A poesia é uma operação do estilo pela qual um complexo de significado é apreendido de um só golpe. A poesia triunfa porque tudo ou quase tudo que nela se diz ou se encontra implícito é relevante; o que não importa foi excluído, como os caroços de um pudim ou os enguiços de uma máquina (WINSATT; BEADERSLEY, 1983, p. 87).

$\mathrm{Na}$ representação da escrita de "Psicologia da composição", interessa ao enunciador que o espetáculo se mostre pronto, em sua autonomia no palco da linguagem, e não em seu processo de composição e seus percalços. Na representação do ato de escrita de Armando, ao contrário, o eu lírico permite que se veja todo o processo, toda a maquinaria utilizada na composição, sobretudo o que foi rasurado, apagado, volta através das frestas.

Faz parte da poética de Freitas Filho este misto de reverência 
e confronto, de louvor e crítica à tradição modernista e, por isso mesmo, sua escrita possui papel de relevo na cartografia da poesia brasileira, como bem assinala Célia Pedrosa (2003, p.02) a respeito da reunião de obra, intitulada Máquina de escrever (2003):

o sólido chão da tradição moderna se transforma em trampolim para um salto no escuro, como diz Drummond. Armando redesenha o legado de nossa melhor estética moderna e sinaliza os vínculos com seu próprio tempo, fazendo da obra reunida, uma alegoria de sua vontade de não ser um sobrevivente de si mesmo, mas um contemporâneo, lembrando as palavras de Murilo Mendes a respeito de sua própria obra reunida. (PEDROSA, 2013, p.02)

A consciência de débito em relação à herança modernista não significa repetir o legado, ao contrário, ela é impulsionadora de permanente diálogo crítico, ora como confronto, ora como desejo de superação. Sem abdicar da evidente filiação de sua poesia à tradição cabralina, Freitas Filho não escamoteia as especificidades históricas em que está inserido, mas, como herdeiro, recusa o papel de mero seguidor, inscrevendo-se num espaço tenso a sua condição de poeta no/do tempo presente.

Essa relação problemática faz dele um poeta a contrapelo dos seus pares contemporâneos ou mesmo distante da ideia de "retradicionalização frívola", exposta por Simon (2011). A fim de avaliar o impacto da matriz modernista em sua obra, exporemos adiante o modo como o poeta reage e dramatiza, no espaço da linguagem, sua atitude de permanente desafio frente à poética drummondiana e cabralina.

João Cabral de Melo é um destes poetas pelos quais Armando Freitas Filho se deixou inocular, conforme assinalado na epígrafe. No entanto, a poética de Cabral projeta-se na obra de Freitas Filho ora de modo pacífico, ora conflituoso. Dialogando com seu antecessor, o poeta também busca libertar-se do seu peso: "O que vejo, enfim, quando sou retrospectivo, para ficar só no âmbito do 
literário, que é um lugar mais ameno no meio da minha vida, é que escrevi, escrevo, o que posso, não o que devo, e o que posso está muito aquém do que devo" (apud ROSA; OLIVEIRA, 2000, p.06).

A consciência de escrever o que é possível e não o que deve, ganha amplitude na poesia brasileira para muitos poetas pós-50, como Sebastião Uchoa Leite e José Paulo Paes, que enfrentam a crise da palavra poética em língua portuguesa do Brasil. Ítalo Moriconi (1992, p. 27) observa que "ofuscado pelo apogeu da estética modernista, o poeta, que já não pode renová-la, só pode repetila" (...).. Repetir, entretanto, é um gesto distante das estratégias de Armando, que prefere marcar posição pelo contraste. É este instigante contraponto que permite a um "poeta forte" (Bloom, 1991), como Armando, inscrever-se na tradição da poesia brasileira, deslendo com rigor e vigor os poetas fortes do modernismo.

Quanto ao cenário poético de ontem e o de hoje, posso constatar, agora, quando, infelizmente, tenho mais espelhos retrovisores disponíveis e menos pára-brisas, que o que conta, de verdade não é o pró, é o contra. Ele é que tempera e, mesmo sabendo que vou ser derrotado (pois esses olhos da mocidade que vem chegando verão a minha morte física), é esse oponente, às vezes todo sorriso, que, no fundo, me faz viver, me mantém em alerta e não me deixa sentar e engordar, antes da hora, de costas para a porta aberta. (apud. ROSA; OLIVEIRA, 2000, p. 6).

A atitude de estar contra, exercitada por meio da intensa reavaliação que faz da obra de João Cabral, desafiando um dos modelos que mais admira, é o que impulsiona Freitas Filho a inserir-se na tradição. A autoconsciência das diferenças contextuais - a que foi experenciada por João Cabral e a que foi vivenciada por ele, no cenário contemporâneo - incita-o a adotar uma postura ambivalente. Ao renunciar à engenharia e à arquitetura cabralina, estabelece forte aproximação com esta mesma poética. Paradoxalmente, verifica-se um impulso de negação em relação àquilo mesmo que admira, inclusive no plano biográfico, uma vez 
que João Cabral foi um poeta com quem Armando manteve fortes laços de amizade.

Neste diálogo crítico e combativo que Armando desenvolve "com e contra Cabral", "pode-se reconhecer o quanto a sua obra se distancia de qualquer formalismo sem deixar de absorver todas as consequências da autonomia da linguagem poética, liberta tanto das amarras do objetivismo quanto do biografismo" (GUERREIRO, 2002, p. 15).

O diálogo com a tradição modernista vem acompanhado do jogo metalinguístico recorrente na poesia do autor de Fio Terra. Compreender este diálogo é significativo pelo fato de representar uma reflexão sobre esta poética que quer estar contra. 0 poema "Para João, com amor e sordidez", publicado em Duplo Cego (2003, p.541) e que traz a epígrafe "Ninguém aqui está interessado em ser simpático", extraída de J. D. Salinger, é bom exemplo deste amor por contraste:

Exercício de estilo, se existe

Não visa, como o de tiro

Um alvo único, fixo e físico

Mas a muitos

Mais de imaginação do que de imagem.

Não usa bala burocrática, numerada

De calibre certo, didático.

E sim um punhado de chumbo

De pedras

Que pega um pouco em tudo

Assinando o nome com garranchos

Sem carimbo

Ou caligrafia pré-fabricada

Picotando o papel jornal com furos de franco-atirador.

(FREITAS FILHO, 2003, p.541)

Um recado com endereçamento nominal, o poema rasura a um só tempo, o sistema unívoco ("que visa um alvo único, fixo e físico"), a gramática de contenção, de precisão, o rigor construtivo alcançado pelo controle da sintaxe e, sobretudo, pelo controle do discurso do 
mestre pernambucano. 0 que se lê é uma acusação inclemente da poética cabralina, para sinalizar o que não se deve repetir: a poética didática, monocórdica, bala de "calibre certo" ou burocrática. 0 gesto é de afrontamento, mas, para Armando, só é possível amá-lo por meio desta sordidez. Como afirma em entrevista Adolfo Montejos Navas (2000): “João Cabral, poeta fundamental - mas péssima influência quando lido de modo servil -, tem de ser enfrentado pelos que vêm depois, até para que possamos, por contraste, amálo melhor. [...] Senti muito a sua morte." (NAVAS, 2000, p. 9). Tratase de uma demarcação de terreno onde a psicologia da composição é exposta como contramodelo. Utilizando o método cabralino de comparar pela oposição, Armando não pretende obter o total controle da linguagem.

0 poema estabelece uma série de distinções entre o seu "exercício de estilo" e o de Cabral, tomando como ponto de comparação a metáfora do "tiro", ou melhor, dos "modos de atirar": um que privilegia a imagem, densa, concentrada do objeto e a outra, que usa a imaginação, aberta, plural. Partindo do verbo intransitivo não "visa", no sentido de "dirigir o olhar para ou apontar arma de fogo contra" o poema vai se expandido o seu discurso bélico (tiro, alvo, bala, calibre, chumbo, pedras) até finalizar com a presença da imagem do atirador altamente especializado, o franco-atirador.

0 alvo a ser atingido aqui é a estratégia composicional do poema Uma faca só lâmina (1955), um dos poemas metalingüísticos mais sistematizados de Cabral e que gira em torno de eixos semânticos permanentes, que beira à obsessão, pelo grau de concentração e interconexões das imagens que perpassam suas oito estrofes. Cabral explora um limitado campo semântico, com imagens que remetem à ideia de acuidade, contundência, acentuando os sentidos que vão de "bala" a "faca", ao "relógio", retornando da última (faca) à primeira (bala). Se, no poema de Cabral, a bala calculada é de "calibre certo", Freitas Filho aconselha lançar as pedras aos punhados, que, ao serem lançados, atinjam muitos alvos inesperados.

A assinatura é um entre tantos indícios de como a escrita de 
Armando evidencia as marcas das contingências, do tempo vivido, incerto, "assinando o nome com garranchos", inscrevendo nesta assinatura as marcas do corpo. Como afirma Sérgio Alcides (1997, p. 100), a poesia de Armando "é da experiência, do experimento, mas não em laboratório tecnocrático, e sim na vida.

\section{Sobre Drummond: a presença que falta}

Se a relação entre Armando e Cabral se dá por meio da desleitura, pela diferença, a longa sequência de poemas em homenagem a Drummond, publicada em Numeral/Nominal (2003), evidencia outra problemática de filiação. Há um nítido desejo de rivalizar com o poeta mineiro, mas, ao mesmo tempo, emerge a consciência da impossibilidade de alcançá-lo. 0 fracasso é anunciado antes de realizar o desafio.

Na segunda parte, "Nominal" figura uma longa sequência de poemas dedicados ao poeta mineiro, uma tentativa de decifrar os mecanismos da máquina de Drummond. Começamos pela leitura de "Pensando em Drummond e Clarice":

A máquina de um, a outra se sentindo uma, e a minha: mecânica, não oferecida tampouco entranhada, enferruja sem metafísica ou metáfora perdendo força a cada dia não dizendo o que durante tanto tempo prometeu - ilusão não era pois o mundo palpita para todos.

0 que faltou foi velocidade na datilografia, acurácia, para captar o que sub-reptício se afastava e mesmo se gritante, os dedos gagos não conseguiam, nas teclas, articular as palavras, o que se exprimia, próximo 
mas sempre além de todo o mecanismo que embora igual aos outros, desistia.

(FREITAS FILHO, 2003, p. 47)

Descrição angustiada do seu deparar-se com os próprios limites diante de uma máquina que não se oferta, como a máquina do mundo, que não se revela. Angústia por não materializar-se no seio da linguagem o que se pretende dizer. Seus dedos gagos não permitem a velocidade, a acurácia para "Captar o que subreptício se afastava". Há, em Armando, um vasto campo semântico que aproxima Drummond de uma espécie de miragem. 0 poeta de Itabira representa a voz forte da qual Armando gostaria de se apropriar, mas cuja presença é ausente e muito distante. É esta presença tão ausente que é descrita no poema "CDA no coração":

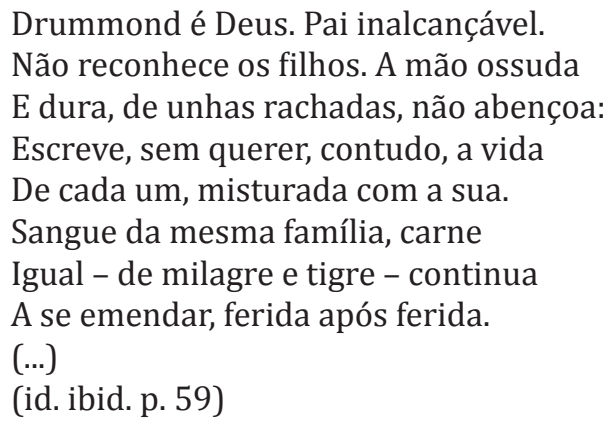

Espécie de código genético, o poeta de Itabira é uma matriz que deu origem a toda uma herança de uma poesia que alia distanciamento crítico e subjetividade, poesia e experiência, vida e linguagem, com as quais o sujeito poético se identifica. Mais do que reproduzir, o interesse aqui é decifrar as estruturas dos genes para apreender o cerne da máquina drummondiana. 0 discurso de veneração deixa vazar certa decepção, resignação instaurada pelo distanciamento desta presença que falta: "Sangue da mesma família" "carne/igual” este pai não permite ser alcançável por nenhum filho. 
E, diante da impossibilidade de decifrar este deus inalcançável, prenhe de humanidade, mas que não se permite moldar-se, modelarse, pois está sempre além, o sujeito lírico sente-se frustrado, como atestam os versos de "Palavra chave", poema que dialoga com "À procura da poesia":

\author{
(...) \\ 0 encaixe desta chave não \\ se corta a priori: seu ajuste \\ se molda a partir da febre \\ que o instante forja - fugaz. \\ Não se faz cópia, do que não se funde \\ Nem memoriza o fecho, a nuvem cinzenta \\ Do seu segredo volátil: então \\ se perde completamente, amnésica \\ isolada, imperfeita, inútil \\ no fundo da gaveta, do pensamento \\ Até que a imaginação refaça \\ Em outra liga de duração semelhante \\ Sua imagem de uso e magia \\ (id. ibid. p. 62-63)
}

Um desejo quase religioso de sacralizar tanto a obra quanto o poeta-pai e a ele religá-lo, como se quisesse ver a face do inapreensível, repete-se no poema "CDA na cabeça":

Sua pedra é do castelo

Do esforço da montanha

Em apurá-lo, com céu e neve.

E como um traço de horizonte

Ao fundo, para iludir melhor

Quem o quer alcançar - logo ali

Logo além - sempre recuando

À mão agrimensora que refaz.

O cálculo, toda vez, mas acaba

Por contar incerto, e se interrompe.

Sua pedra é do castelo

Não soletra nem se metaforiza. 
Não se deixa paginar - bruta

Não se lapida nunca, não

Se faz rara, nenhuma máquina

A consegue aparar, pois se parte

E se funde, no trabalho, a ela:

Peça engastada de ferro, aresta

Calcária, rocha, barra e fere

0 passo do caminho, as mãos presas.

(id. ibid. p 61)

Entre a gratidão e a admiração intelectual, metáforas e imagens circulam em torno do poeta de Itabira, ressaltando sua presença intangível. Drummond é a linha do horizonte, que ilude quem quer alcançá-lo ("está logo ali, logo além").

Há algo de Sísifo neste sujeito que busca apreender os segredos da máquina Drummond. A estrada pedregosa, aberta pelo poeta mineiro, incita-o a percorrê-la. Mas o poeta desiste para perfazer o seu próprio percurso: "À mão agrimensora que refaz./0 cálculo, toda vez, mas acaba/Por contar incerto, e se interrompe". 0 gesto de "contar incerto", instaura no ato da sua escrita a errância e o imponderável, interrompendo o percurso da procura.

É a inserção da experiência, a transformação da vida em linguagem, "sem ser calculado e sem contagem", o ponto de intersecção da poética de Armando com a de Drummond. Corpo e subjetividade impregnam todo o tecido textual, sem que isso signifique centralização narcísica. Ao contrário, trata-se de um sujeito em permanente trânsito, "à deriva", "ficcionalizado", "ferido" e compulsivo.

A "pedra bruta, que não se lapida e não se faz rara", assim como seu sistema plural que abarca o vasto mundo são os elementos admirados em Drummond e, por confronto, rejeitados em João Cabral. No entanto, a confrontação cabralina não exclui a "inevitável marca de Cabral na economia de sua escritura". (LOSSO, 2002, p. 14). Uma escrita que assume os riscos e as incertezas da linguagem, mas sem abandonar o rigor. 0 poeta impulsivo, desenfreado e hostil, 
é o mesmo que baliza e controla o verso, fazendo conviver exatidão e abismo, construtivismo e impureza.

A leitura de Armando nos fornece subsídios para entender como as gerações contemporâneas vivenciam a modernidade não mais como uma "tradição da ruptura", mas como dilema em relação tanto com o tempo presente quanto com os poetas modernistas.

\section{Referências bibliográficas}

BLOOM, H. A angústia da influência; uma teoria da poesia. Rio de Janeiro: Imago, 1991.

ELIOT, T. S.Tradição e talento individual. In:_Ensaios. São Paulo: Art Editora, 1989.

FREITAS FILHO, A. Máquina de escrever: poesia reunida e revista. Rio de Janeiro: Nova Fronteira, 2003.

. Três Mosqueteiros. In: MASSI. A. (Org) Artes e Ofícios da poesia. São Paulo e Porto Alegre: Secretaria Municipal de Cultura e Ofícios. 1991.

GUERREIRO. E.G.B. Travessia cega de um desejo incurável: a experiência sublime na obra de Armando Freitas Filho. Dissertação de Mestrado. Rio de Janeiro: UFRJ, 2002.

MARTELO, R. M. A forma informe: leituras de poesia. Lisboa: Assírio Alvim, 2010.

MASSI. A. (Org) Artes e Ofícios da poesia. São Paulo e Porto Alegre: Secretaria Municipal de Cultura e Ofícios. 1991. 
MELO NETO, J. C. de. Obra completa. Rio de Janeiro: Nova Aguilar, 1994.

NAVAS, A. M. Correspondencia celeste; nueva poesía brasileña (1960-2000). Madri: Árcora Ediciones, 2001.

PEDROSA, C. O poeta definitivo. Jornal do Brasil, Rio de Janeiro, 29 nov. 2003. Idéias, p. 2-3.

ROSA. M. A; OLIVEIRA. A. Coisa incerta. Suplemento Literário Minas Gerais. Belo Horizonte, 10 de novembro de 2000.

SECCHIN. A. C. João Cabral: a poesia do menos. São Paulo: Duas cidades; Brasília: INL, Fundação Nacional Pró-Memória, 1985.

SIMON, I. M.; DANTAS, V. Negativo e ornamental. Um poema de Carlito Azevedo em seus problemas. Novos estudos, CEBRAP, n. 91, São Paulo, nov. 2011.

SIMON, I. M. Condenados à tradição. O que fizeram com a poesia brasileira. Revista Piauí, n 61, 2011. http:// revistapiaui.estadao.com.br/edicao-61/aceleracao-docrescimento/condenados-a-tradicao. acessado no dia 09 de janeiro de 2012.

WINSATT W.K.; BEADERSLEY, M.C. A falácia intencional. In: COSTA LIMA. L. (Org.). Teoria da literatura em suas fontes. Rio de Janeiro: Francisco Alves 1983. p. 86-103. 



\title{
POETIC EXPERIENCE AND CULTURAL KNOWLEDGE IN P.K.PAGE'S "BRAZILIAN FAZENDA"
}

\section{EXPERIÊNCIA POÉTICA E CONHECIMENTO CULTURAL EM "BRAZILIAN FAZENDA" DE P.K.PAGE}

Sigrid RENAUX ${ }^{1}$

\begin{abstract}
Starting from Northrop Frye's statement that "it is not a nation but an environment that makes an impact on poets, and poetry can deal only with the imaginative aspect of that environment", this paper ${ }^{2}$ investigates the impact that the specific environment of a Brazilian farm has made on P.K.Page, as revealed in her poem "Brazilian Fazenda". In the description of her surroundings from an unusual perspective, she not only highlights the imagistic precision of her visual perception but simultaneously foregrounds her poetic sensibility, as she transforms the referential aspects of the fazenda into an intense poetic and cultural experience.
\end{abstract}

KEY-WORDS: Canadian poetry. P.K.Page. Brazilian culture.

The aim of this article is to investigate the impact that the experience of visiting a Brazilian coffee farm made on P. K. Page, as revealed in her poem "Brazilian Fazenda". Drawing on Northrop

\footnotetext{
${ }^{1}$ Centro Universitário Campos de Andrade (UNIANDRADE). Professora titular do Curso de Mestrado em Teoria Literária.

2 An earlier, shorter version is available in CD-ROM: Anais do VI Congresso Internacional da ABECAN: Transculturalismos. Porto Alegre: UFRGS, 2002.
} 
Frye's theoretical postulations in The Bush Garden: Essays on the Canadian Imagination, I discuss how Page describes her surroundings from an unusual perspective, caught as she is between two cultures, as well as between a real and an imaginary world. Both the imagistic precision of her visual perception and her poetic sensibility are highlighted as she transforms the referential aspects of the fazenda into an intense poetic, cultural and metaphysical experience. My response to the poem reflects the delight I feel as a Brazilian on reading it, as well as the assurance I have gained from Frye's critical views regarding poetic experience and cultural knowledge.

In his "Preface to An Uncollected Anthology", Frye presents certain critical principles which he considers essential for dealing with Canadian poetry:

The first of these principles is the fact that the cultivated Canadian has the same kind of interest in Canadian poetry that he has in Canadian history or politics. Whatever its merits, it is the poetry of his own country, and it gives him an understanding of that country which nothing else can give him.

He also claims that "the qualities in Canadian poetry which help to make Canada more imaginatively articulate for the Canadian reader are genuine literary values, whether they coincide with other literary values or not."(FRYE, 1971, p.163).

Both statements are already significant for an understanding of the Canadian reader's stance vis-à-vis the poetry of his or her own country, and could thus serve as a means of comparison with the attitude adopted in other cultures. They also help us to keep in mind that literariness ${ }^{1}$ is the essential quality in the literary production of any country.

However, it is actually the following assertion by Frye that will be the starting point for my own argument: "It is not a nation but an environment that makes an impact on poets, and poetry can deal 
only with the imaginative aspect of that environment." (FRYE, 1971, p.164). This provides me with the key to a better insight not only into Canadian poetry, but also into the poems that P. K. Page has written about her experience in Brazil. These poems make the landscape of my own environment suddenly become more meaningful, "more imaginatively articulate", seen as it is not through the eyes of my own countrymen, but through the eyes of a cultivated Canadian poet.

P.K. Page was already a well-known writer when she arrived in Brazil in 1957 with her husband, William Arthur Irwin, the newly-appointed Canadian ambassador. Besides poems in several Canadian poetry magazines, she had also published a novel, The Sun and the Moon (1944) and two books of poems, As Ten, as Twenty and The Metal and the Flower, which won the Governor General's Award for poetry. As critical comments emphasize, the poems in As Ten as Twenty (1946) showed Page's "strong awareness of English poetic trends in the 1930s" and her sharing "the psychoanalytic preoccupations of contemporary English poets", while the poems in The Metal and the Flower (1954) reflect "in their sharply visual presentations of concrete situations (...) the cinematographic perceptions" she had acquired while working as a scriptwriter for the National Film Board (TOYE, 1983, 630-31). From 1942 onwards Page also became associated with the Preview group in Montreal, where she met F.R.Scott, A.J.M.Smith and others who had introduced the aesthetics of modernism into Canadian letters (ORANGE, 1987,p. 9).

The fact that Page studied art and learned to speak Portuguese during the time she lived in Rio de Janeiro ${ }^{2}$ already suggests how fascinated and intrigued she must have been with her new environment. As she said in a 1975 interview, "Well, I think Brazil gave me a whole dimension or emphasized a dimension that I had, I don't know how to explain it, but I honestly felt in a kind of way that my consciousness was altered." (KEELER, apud ORANGE, 1987, p.4). Yet even though Page's "consciousness was altered" by 
the Brazilian environment, the impact of this new landscape on her poetic sensibility would only be transformed into verse many years later, as during the time she lived away from Canada (from 1953 to 1964, when W. A. Irwin served as Canadian ambassador in Australia, Brazil, and Mexico) she wrote comparatively little poetry. She concentrated instead on paintings and intricate drawings, which show how her various arts reflect one another, evoking as they do both poetic and aesthetic images (TOYE, 1983, p. 631).

This background, plus the fact that the traditions out of which Page's poetry grows are the French Symbolistmovement, Surrealism, and the modernists - she herself lists Lorca, Rilke, Auden, Eliot and Stevens, among others, as having influenced her (ORANGE, 1987, p. 8) - makes it even more of a challenge to evaluate a poem such as "Brazilian Fazenda" (PAGE, 1997, p. 123), in which the historical, religious and cultural elements of the external landscape become transmuted and reappear as a lyrical vision. It is this challenge that underlies my reading of Page's poem, as she moves back and forth from a visual portrayal of the external landscape to a conceptual rendering of the experience.

The title "Brazilian Fazenda" immediately arouses a dual feeling in Brazilian readers: firstly, a sense of a déjà vu, due to the familiarity which the image of a Brazilian fazenda conveys to us Brazilians, as it is part of our historical and cultural background ${ }^{3}$. On the other hand, the title also creates in us a sense of expectancy, of curiosity as to how a foreigner would be affected by this strange new environment. This dual feeling is reinforced by the alliteration (LEECH,1969, p. 92) 4 and consonance in "Fazenda" and "Brazilian", which seem to draw the words together both in sound and meaning (JAKOBSON, 1971, p. 371), despite their belonging to different languages and cultures.

This combination of two different words/worlds will also characterize the poet's 'suspended' position in the poem, as Page, caught between two cultures, is not only viewing one country with the eyes of another. She is also divided between a real, 
representational world and an imaginary one, between referential and emotive language, as her literal or scenic rendering of the farm merges with the visionary experience which this visit to a fazenda has produced in her. In reply to my request as to whether she could recontextualize the specific experience that led to the poem, Page wrote the following to me on June 29,2001 :

The specific experience that gave rise to the poem was in 1957 although I didn't write the poem until many years later. In my Brazilian Journal, pp. 43-45, I describe our visit to a fazenda in São Paulo owned by the Meireles family. It was old, elegant and very beautiful. (...) It was the first fazenda I had ever seen and its beauty made the day special for me.

This double distancing in time and place (the poem was published in 1967 and "written about that time") recalls Wordsworth's poetic principle that poetry "takes its origin from emotion recollected in tranquillity." (WORDSWORTH, 1973, p. 608), and stresses even further the extent to which this experience must have affected her, and how the beauty of this fazenda made that day "special" for her.

Although "Brazilian Fazenda" is composed of 23 lines of irregular length grouped in seven strophes, this graphological irregularity, so characteristic of free verse, is deceptive. A closer examination of the poem reveals that every strophe encapsulates one complete scene or event and that the prosodic pattern of each strophe is further bound not only by enjambment but also by subtle sound parallelisms, discussed below. These enhance the semantic relationships among the images impregnating each scene, and highlight the intricate texture that underlies Page's verbal art.

At the same time, the sentences in the first six strophes, in which the persona gives us a scenic yet surrealistic rendering of the farm, are made up of coordinate clauses of equal rank, which give the images a cumulative effect. On the other hand, the complex sentence in the last strophe, in which the clauses are bound by subordination, 
will reveal the effects of the "extraordinary" experience that this visit to a Brazilian plantation has caused in the persona: her plea to return on an ordinary day, in order to look at the fazenda with literal eyes.

This syntactic organization is reinforced by the way the semantic units of the first six strophes (lines 1-17) are dominated by the adverbial phrase "that day" with which the poem begins, and by the use of the past tense in which the persona narrates the events. By contrast, the seventh strophe (lines 18-23) is controlled by the adverbial phrase "on a day", and the persona addresses herself in the present tense. In this manner, a sophisticated, multi-layered linguistic structure emerges which will transform the apparent randomness of the referential details caught by a foreigner's eye into a coherent yet complex whole as well as an intense poetic and cultural experience.

As we enter this Brazilian fazenda, we are immediately drawn into the past, with the connotations of distance in time and memory evoked by "that day":

\author{
That day all the slaves were freed \\ Their manacles, anklets \\ Left on the window ledge to rust in the moist air \\ And all the coffee ripened \\ Like beads on a bush or balls of fire \\ as merry as Christmas \\ and the cows all calved and the calves all lived \\ such a moo.
}

At the same time the deictic "that" draws us into a definite day in the past, already understood by the persona, as she visualizes "that day" on which "all the slaves were freed", reminding us of the actual day on which slavery was abolished in Brazil by the Lei Áurea, May 13, 1888. A further link between the day and the event is established by the assonance in day/slaves, while "freed" is given 
visual prominence and thus further highlighted by being placed at the end of a line.

Freed from slavery and thus from their symbolic chains, the slaves have their handcuffs metaphorized into ornaments, the juxtaposition of the images in "manacles, anklets" leading to their superposition not only in meaning and form (both are plural nouns) but also in sound and graphology, as "anklets" is partially contained in "manacles". Significantly foregrounded in line 2, and referred to in Page's Brazilian Journal as she describes her visit to the first of these "two early nineteenth-century fazendas"-"Off the hall, a room full of trophies and slave relics, and off that, the slaves' room." (PAGE, 1997, p.43) - these "slave relics" consequently become the concrete signs of the abolition of slavery not only on this fazenda but, by extension, in the whole country.

The fact that the relics were "left on the window ledge", either forgotten or abandoned, "to rust in the moist air", to be corroded and spoiled by nature itself, is highlighted by the alliteration in left/ledge, manacles/moist and the consonance in rust/moist. Furthermore, by leading us to visualize the window as a gateway to air, light and vision, the image also emphasizes the unnaturalness and cruelty of the institution of slavery. The word "air" is strategically placed at the end of the first triplet and introduced phonologically by "their". As the first element, the first essential need of human life, air is symbolic not only of space as the medium for movement and the emergence of life processes but also of freedom as dematerialization (VRIES, 1974, p. 7). It thus reminds us of the newly acquired freedom of the slaves and of the removal of their material emblems of bondage.

As a consequence, "moist air" or "moisture", suggesting a state of indetermination between the formal and informal, as well as being the source of fertility, will destroy what is unnatural and simultaneously prepare the way for the renewal of nature that takes place in the next two strophes. This transition is also prefigured phonologically in the alliteration rust/ripened: 
and all the coffee ripened

like beads on a bush or balls of fire

as merry as Christmas

Paralleling the juxtaposition of manacles/anklets, emblematic of the abolition of slavery, the syntactic connection between the first and second triplets effected by "and" establishes several links between the date of the liberation of the slaves and the time of the ripening of coffee on the fazenda. First of all, it brings out a seminal aspect of Brazilian history and culture by reminding us of how 19th century coffee plantations, especially in the states of Rio de Janeiro, Minas Gerais and São Paulo relied on slave labor. This makes the time link established between the liberation of the slaves and the ripening of the coffee even more significant, by stressing the deep and contradictory connections that exist between bondage and liberty, man and nature.

Vegetation can be said to have two main emblematic implications: in relation to its annual cycle, it is symbolic of death and resurrection as it follows the pattern of winter and spring, while its abundance links it to fertility and fecundity (CIRLOT, 1971, p. 359). Coffee naturally shares these implications, which can be extended if we remember that beans are not just a form of food but also symbolize energy, resurrection and reincarnation (VRIES, 1974, p. 37; CHEVALIER \& GHEERBRANDT, 1974, p.314 ), while seeds are associated with fertility, growth, and human nature (VRIES, 1974, p.409); CIRLOT, 1971, p.282). The date consequently acquires an even broader dimension by linking a historical event to a natural one. The renewal and fertility of vegetation stresses the fundamental unity of life, a metaphor that continues to be developed to the end of the poem, as vegetation, like man, is born from the earth, and an incessant circuit runs through the lower and higher levels of life (CHEVALIER \& GHEERBRANT, 1974, p 363). The combination of the two events thereby becomes a metaphor for the "fundamental unity of life", as the ripening of the coffee not 
only coincides with the date of the liberation of the slaves, but, like the anklets, becomes emblematic of their freedom.

This superposition is further enriched by the simile "like beads on a bush or balls of fire" through the structural and conceptual analogies established between the tenor and vehicles of the comparison (LEECH, 1969, p.151). ${ }^{5}$ By way of their similarity with beads and balls of fire, these red coffee beans are visualized as bright ornaments hanging on the green bushes, making the work of resemblance - their roundness, color and ripened splendor become a "pictorial or iconic moment" (RICOEUR, 1979, p.143). If we compare these lines to Page's description of the coffee plantation ten years before, we become aware again of how the poet's and painter's eye has kept the vivid colors and light of her experience: "After luncheon we saw the coffee plantation. Bright, shiny green bushes with scarlet berries - birds in a bush, beads of fire. As far as the eye could see, coffee bushes stippled the lovely, undulating land." (PAGE,1997, p. 44). ${ }^{6}$ The comparison also brings out the way the poem moves both from description to perception and from the presentation of imagery to the use to which it is put, as "the poetic image is an instrument of the poetic language." (SHKLOVSKY, 1990, p. 3).

At the same time, the conceptual analogies foregrounded in "beads", connoting not just decoration but also prayer (VRIES, 1974, p. 37), and "balls of fire" - "ball" being symbolic of the earth, perfection, eternity, the circle (VRIES, 1974, p. 33; CIRLOT, 1971, p. 46-7), and "fire" of the essence of life, sun, fertility (VRIES, 1974, p. 187-88) as well as of transformation and regeneration (CIRLOT, 1971, p. 105) - emphasize the "fundamental unity of life" symbolized by vegetation, adding a festive, joyous, religious element.

We cannot detach the particular use of the image of the beads, as an explicit comparison with the coffee beans, from its symbolic associations with prayer, not only because in a largely Catholic country such as Brazil the word "beads" would immediately be associated with the beads of a rosary, butalso because these symbolic 
associations are reinforced by the simile "as merry as Christmas". The images of the fertile coffee bushes adorned with red beads and shining in the sun merge with the associations in folklore of the sun shining through the trees at Christmas as a symbol of fruitfulness, while the Christmas tree symbolizes enduring life, fertility and resurrection (VRIES, 1974, p. 97-98; CIRLOT, 1971, p. 346-8). Christmas becomes intertwined with the symbolism of vegetation expressing this fundamental unity of life, further highlighted by its association with celebration and spiritual renewal. One could even say that the negative imagery of roundness prefigured in manacles/ anklets is now transformed into a positive imagery of coffee beans/ beads/balls of fire, making the joy of Christmastide also become an objective correlative for the joy of the freed slaves.

Various sound parallelisms, such as the alliteration in beads/ balls/bush, the partial alliteration in coffee/Christmas, the assonance in ripened/fire, and the syntactic and phonological structure "as merry/ as -mas", serve as an undercurrent to enhance the stressing of "Christ-" as the most important word in the line. All these visual and semantic associations will be transposed into the third strophe, again suggesting the way plants and animals bring forth new fruit and offspring, when nature is ripe:

and the cows all calved and the calves all lived such a moo.

The scene as depicted in Page's Journal shows clearly how she has selected an image and remodeled it in such a way that it fits into this atmosphere of release, joy and fruitfulness established in the first two strophes: "In the dairy we visited the calves, which sucked your fingers as if they were udders when you put your hand out to stroke them, and saw the elaborate forecasting, month by month, of the number of calves to be born"(p. 44). Nature continues its fertility cycle as we move from man to vegetation and to animals. The image of the cows giving birth projects the cows' symbolic associations 
with earth and fertility (VRIES, 1974, p. 114; CIRLOT, 1971, p. 69), while the image of the young calves adds a touch of innocence and tenderness to the picture, with the humorous, onomatopoeic "moo".

The alliteration in cows/calved/calves, reverberating backwards to include coffee/cows/calves, draws the images of vegetation and animals even closer together in sound and meaning, as we visualize the sheer number projected by the repetition of "all the cows/ all the calves". Moreover, the structural parallelisms in the first three strophes (all the slaves were freed/and the cows all calved/and all the coffee ripened/and the calves all lived) reinforce the connections already established at the three levels of linguistic description: realization, form and semantics (LEECH, 1969, p. 37). The structural and conceptual analogies overlap, giving the four statements a kind of semantic equivalence. The strophes thus become a single metaphor for the "fundamental unity of life".

Still within the sphere of "that day", which initiates the poem, the following three strophes (lines 9-17) present another angle of the fazenda, as we move from an external landscape to the veranda of the colonial house:

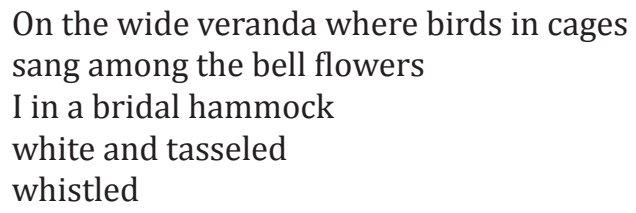

Page describes the scene thus in her Journal: "on a deep veranda, dark from creepers with pink bells, were birds in cages and a white tasseled bridal hammock." (1997, p.43). In contrast with the freedom of the extensive fields of the coffee plantation, she presents a series of images of containment or partial containment. The wide veranda is typical of a Brazilian fazenda, with its open space along the sides of the house and the roof supported at the front by pillars, and has connotations of shelter and security but also contact with the outside world/landscape. Cages, like the manacles, 
are emblematic of cruelty and imprisonment (VRIES 75). As such they highlight still further the positive symbolic associations of the birds with air, wind, sun, divine essence, immortality and creation (VRIES, 1974, p. 47; CIRLOT,1971, p. 28), and of their song with the winds, fertility and enticement (Vries, 1974, p. 431), by negating them, emphasizing the birds' lack of freedom. The showy pink bell flowers indirectly recall the symbolism of the birds' song through the associations of "flower" with beauty, joy, transitoriness and the soul (VRIES, 1974, p.194-95; CIRLOT , 1971, p.109-110). They thus remind us of the connotations of the "bell" itself - worship, joy, freedom, fertility, the creative power of sound (VRIES, 1974, p.44; CIRLOT, 1971, p. 24) - while at the same time their shape, like the cage, suggests containment.

As if all these images of containment are turned on herself, we finally visualize the persona's "I" precisely in the middle of the poem, encapsulated by the sentences above and below, enwrapped and suspended "in a bridal hammock". "White and tasseled", it is not only adorned with bell-shaped tufts, but is also, in its bridal whiteness and beauty, symbolic of purity, illumination, intuition and the unconscious (VRIES, 1974, p. 499; CHEVALIER \& GHEERBRANDT, 1974, p. 206). This typical Brazilian artifact projects first of all the persona's literal suspension between air and ground, but by involving her in a state of illumination and intuition it also suggests her state of suspension between two worlds, as mentioned above: between a historical past and her present moment, between her liberty and the confinement of the slaves and birds. Suspension, as unfulfilled longing or tense expectation, will thus propitiate the merging of reality and surrealism in the next strophe.

While our senses have already been stimulated as we moved through the three initial strophes, sight, sound, scent and touch also pervade this network of intricate visual parallelisms of containment. Veranda/ cage/ bell flower/ tassel/ hammock are all bound by subtle sound parallelisms, while the appearance of the persona's "I" is phonologically preceded and then followed by its 
asymmetrical assonance with wide/bridal/white. The sequence of nasals and liquids in sang/among/bell reflects the sonority of the birds' song, with a slight reechoing of "among" in "hammock", while other effects such as alliteration or partial alliteration in bird/bell/ bride, consonance in sang/among, and assonance in tasseled/ hammock further contribute to the drawing together of sound and meaning. In addition, the graphological similarities in "wide veranda" justify Page's change of the original "deep veranda" in the Journal to "wide".

We arrive now at the only action the persona performs in the poem: to whistle. On a first reading, the whistling only seems to imply that the persona, by imitating the birds' singing, is trying in an inconsequential way to pass the time. However, the alliterative effects and visual similarity between white/whistled, plus the rhyme tasseled/whistled and the assonance in I/bridal/white, once more foreground the intimate relationship between sound and sense, between whistling and being suspended. The paradigmatic and syntagmatic equivalence of the two clauses "birds in cages sang among the bell flowers/ I in a bridal hammock, white and tasselled, whistled" suggests a symbolic connotation of whistling, as a general magic act or archaic device for attracting the theriomorphic deities (VRIES, 1974, p.499; CIRLOT, 1971, p.372). This reinforces the sense of the persona being suspended between a real and a surreal world, leading to the merging of these two worlds. In whistling she has performed a magical act, for the external landscape reappears to her as vision in the next strophe:

and bits fell out of the sky near Nossa Senhora who had walked all the way in bare feet from Bahia.

Blue is the color associated with the immensity of upper space and depth, and thus with freedom, spirituality and eternity (VRIES, 1974, p.54; CIRLOT, 1971, p.53). The bits of sky not only fall "near Nossa Senhora" but are emblematic of her very colors, blue and 
white (FERGUSON, 1972, p.151). They thus establish an intimate connection between this vision of Our Lady, surrounded by the blue sky and wrapped in a sky-blue mantle, and the way she is portrayed in images and paintings in Catholic churches. This is probably how Page saw her when she visited the chapel in the fazenda, "with a beautiful Nossa Senhora" (1997, p.45). The vision brings out clearly the surrealists' unification of exterior reality with interior reality, in which the real and the imaginary, the past and the future, the high and the low, the communicable and the incommunicable cease to be perceived as contradictory (PREMINGER, 1974, p.821). It is then further amplified in the next line as the persona, with almost metaphysical knowledge, imagines the coming of this image to the fazenda.

The distancing in time and space, which sets another frame around Page's actual visit to the fazenda and the writing of the poem, serves to make this vision pregnant with religious, cultural and historical connotations. The past perfect already places the action at a time before "that day", the day the slaves were liberated, while "in bare feet" symbolizes humility and willing servitude because the foot touches the dust of the earth (VRIES, 1974, p.19798). It brings to mind both the image of Nossa Senhora barefoot and the bare feet of the slaves. "From Bahia", besides bringing to mind the long journey on foot to be traveled to reach the fazenda, evokes its fascinating history. Bahia was where the Portuguese made their first landfall in Brazil, where the first mass was celebrated, the first capital of Brazil and also the richest captaincy or province in the first half of the 18th century, thanks partly to its being a center for the slave trade.

As Page confirms in her letter

Looking at the poem today I think, in reference to the slaves, I was trying to incorporate a small piece of Brazilian history. We had not been to Bahia at the time we visited the fazenda [1957], so from the vantage point of '67 [when Page wrote the poem] I was trying to make 
the fazenda a vehicle for other elements of Brazil that impressed or moved me.

While a preliminary reading of this line might make it seem like a continuation of the persona's visionary/surrealistic experience, as she conjures up the picture of Nossa Senhora coming to the fazenda back in the days of slavery, we cannot ignore the fact that an image of Our Lady could literally have been carried from Bahia by barefoot slaves on a litter with poles, as is still customary in religious street processions. The line also brings to mind religious pilgrimages in which people walk barefoot, even on their knees, to obtain or pay for a certain grace. Moreover, the literal and the figurative use of walking "in bare feet" is not just a question of transferred meaning, a concretive metaphor (LEECH, 1974, p.158) attributing physical existence to the image of Nossa Senhora. Walking "in bare feet" actually merges the image of Nossa Senhora walking barefoot with that of the slaves, as if by walking barefoot she is identifying with them and showing her sympathy towards them, or walking towards them, on "that special day" of their liberation.

This line, foregrounded by being the longest in the poem and thus iconic of "walked all the way", is further interlocked by phonological parallelisms such as the alliteration in bits/bare/ Bahia and Nossa/Senhora, the assonance in I/sky, bits/lit, feet/ Bahia, and the alliteration and assonance in "walked all the way", "all" also being visually contained in "walked". At the same time, the assonance in bits/lit provides a transition between this strophe and the next:

and the chapel was lit by a child's fistful of marigolds on the red velvet altar thrown like a golden ball.

Still subordinate to "that day", the magic atmosphere of the previous strophe continues in the next, and again has its origin in excerpts from Page's Journal: 
The second fazenda, smaller than the first, was equally old. ...

The main room downstairs was shaped like a dumbbell.... Flowers, in a child's small bunches, without leaves (...) pushed tightly into mug-shaped vases, were perfectly placed by a painterly eye. ( ...)

After the semen , ${ }^{7}$ the chapel, with a beautiful Nossa Senhora, and on the altar, as in the house, the same child's tight fistful of flowers - marigolds this time, against the red velvet backcloth. (1997, p. 44-45).

From the openness of the external landscape in the last strophe we move back to an image of containment, that of the chapel that envelops visitors in its religious atmosphere. The chapel on a Brazilian fazenda may be a separate building or part of the main one, and is usually dedicated to the Virgin Mary. As marigolds open from daybreak to noon, then stay closed till night, the "child's fistful of marigolds" that lights the chapel can be seen as emblematic of the sun (VRIES, 1974, p. 313), while their golden color associates them with spiritual illumination and pure light, the heavenly element in which God dwells. (FERGUSON, 1972, p.42).

At the same time, "the fistful of marigolds" takes us back to the image of Nossa Senhora, since in Christian symbolism this flower is also an attribute of the Virgin Mary (VRIES, 1974, p.313), while the color gold symbolizes the color of her hair (VRIES, 1974, p. 220). For this reason, other connotations of the marigold such as constancy, mercy, devotion and piety become virtues which are associated with the Mother of Christ. The marigold also partakes of the general symbolism of the flower, regeneration, thereby linking back with the atmosphere of renewal in nature stressed in strophes II and III, on "that day" on which the slaves were freed.

The fact that the fistful of marigolds has been left on the altar by a child brings out the association of children with purity, spring, fertility and unity in nature, so that the image shares that same atmosphere of renewal in nature. The child's symbolism as mediator and bringer of healing (VRIES, 1974, p.96) can also 
suggest renewed faith in the future of mankind. It also reinforces the symbolism of the marigolds as regeneration, and hence the fundamental unity of life.

This religious atmosphere attains its greatest significance in the image of the altar, emblematic in Christian Art of the presence of Christ in the Sacrament of the Eucharist (FERGUSON, 1972, p.161), as well as of devotion, sacrifice and faith. Its significance is enhanced by being covered with red velvet, for the color red, apart from its associations with light, resurrection, gold, love and fire (VRIES, 1974, p.382-83), is used during the Church's season of Pentecost. "That day" is thus inserted even more deeply in a religious season, established in strophe II, and then reinforced in strophe V.

Closing the strophe, the simile "thrown like a golden ball" foregrounds the structural analogy between a fistful of marigolds and a golden ball on account of their roundness and color. Besides merging their structural and conceptual analogies, the overlapping of the images simultaneously retrieves the imagery and symbolism of "balls of fire" and reinforces the intimate connection between the renewal of nature and the religious atmosphere which impregnates strophe II and the scene inside the chapel. Above all, the placing of the simile at the end of the first part of the poem, subordinate to "that day", makes the visual and symbolic associations of "golden ball" an illuminating final image of the perfection of this "extraordinary" day on which the slaves were freed, a perfection that once more recalls the fundamental unity of life.

The images in this strophe are again interspersed with sound parallelisms that enhance their semantic relationships. Chapel/ child are bound by alliteration, while chapel/marigolds, red/velvet, gold/golden/thrown, altar/ball are bound by assonance. Most conspicuously, perhaps, /l/ occurs in almost all the words of the strophe, and / $\mathrm{r} /$ to a lesser extent. Besides further interlocking the images in chapel/lit/child, red/velvet/altar, golden/ball and fistful/marigold, the liquids add a touch of softness to the images and fluidity to the lines, enhancing the delicacy and beauty of the 
vision. These parallelisms are then carried over into the second part of the poem, with the assonance in thrown/golden/Oh also establishing a phonological transition between the two segments.

The last and longest strophe contains the second time frame in the poem, for in contrast with the former strophes, controlled by "that day" and narrated in the past tense, this one is controlled by "on a day", and the persona now addresses herself in the present tense:

\author{
Oh, let me come back on a day \\ when nothing extraordinary happens \\ so I can stare \\ at the sugar-white pillars \\ and black lace grills \\ of this pink house.
}

The strophe opens with the emphatic interjection "Oh," its hint of regret heightened by the silent stress which follows the comma, conveying the strength of her emotion as she utters her prayer or invocation: "let me come back on a day/ when nothing extraordinary happens". With this a contrast is immediately established between "that day" on which "extraordinary" (from extra-ordinem > outside the usual order) events took place and this "ordinary" (inside the usual order) day on which she longs to return.

As the persona realizes the imaginative distance which separates the "ordinary" from that magical moment when the referential world became an imaginary one, the historical past merged with the here and now of her experience, and a golden glimmer imbued and fused the external and internal landscapes, her plea to return on an common day becomes a prayer to see, to "stare at" reality again, as if the surrealism ${ }^{8}$ of her vision has been too intense for her eyes. "Stare" is strategically foreshadowed in "nothing extraordinary", for "nothing" annuls "extra", allowing "stare" to stand out. Its letters also form a chiasmus with "extra", revealing their contrastive implications of vision versus reality. "Stare" thus becomes the most 
meaningful word in the line, further emphasized by being placed at the end.

As the subordinating conjunction of purpose "so" suggests, in the concluding statement "so I can stare", the persona only wishes to look, literally, with eyes fixed and wide open, at the façade:

\author{
at the sugar-white pillars \\ and the black lace grills \\ of this pink house.
}

One could almost say that, by looking steadily and intently at the concrete façade of the house, she would not allow herself to visualize "extra"- ordinary events taking place, almost as if "stare", like "nothing", annulled the implications of "extra".

Comparing these last three lines with the entry in Page's Journal - "We visited two early nineteenth-century fazendas. The first, a colonial house, light pink with white pillars, and lacy black grilles on the windows." (1997, p.43) - there seems to be little alteration at first sight between what is recorded as fact and as fiction. However, by qualifying the white pillars as "sugar-white", by removing "on the windows" from "black lace grills", and by simplifying "a colonial house, light pink" to "this pink house", these exterior features, subtly bound by the consonance in pillars/grills/house, become even more emphasized, besides evoking historical and cultural associations again in the Brazilian reader. The sugar-white color of the pillars, symbolic of ownership, remind us that sugar was the main produce of Brazilian fazendas up to the end of the $17^{\text {th }}$ century. The black lace grills, in spite of their fine ornamental design, connote protection against outsiders but also, by retrieving the image of the manacles, imprisonment. Their black color, moreover, reinforces the association with slaves. The "pink house", a final image of containment, brings back the image of the colonial house with which Page started her Journal entry, but in an inverted order, thus projecting the contrast between the vision of freedom 
established in the first line and that of bondage in the last line of the poem.

In this way, the last three images of the poem simultaneously become emblematic of the three basic elements of the Brazilian colonial economic structure - the great plantation, one-crop farming, and slave labor - making the poem end, despite the persona's wish to only "stare" in aesthetic contemplation at the beauty of this colonial house, with a concrete vision of economic and cultural dominance. ${ }^{9}$

Our entrance into this "Brazilian Fazenda" has thus provided us on the one hand with a scenic rendering of the environment, foregrounding the images which have caused an impact on the poet's visual perception. However, the description of the external topography also reveals the inner eye of the poet, as, in her reverie and with her poetic sensibility, she evokes and transforms the natural events, through the richness of their symbolic connotations, into a transcendental experience. Above all, by linking her almost metaphysical knowledge to her cultural knowledge of Brazil further stressed by the time gap between the experience and the writing of the poem - and by retrieving historical, religious and cultural associations which enhance still further the unification of exterior with interior reality, Page has created an unforgettable lyrical vision of a Brazilian farm.

As a verbal message, projecting the emotive function of language conveyed in thelyrical "I" and breaking the arbitrariness of referential language through foregrounded phonological, morphological and syntactical parallelisms as well as by paradigmatic and syntagmatic equivalences, this vision simultaneously establishes the poetic function of language, centered on the message (JAKOBSON, 1971, p.356), as the determining function of this poem.

Frye ends his "Preface" by stating that Every good lyrical poet has a certain structure of imagery .typical of him as his handwriting, held together by certain recurring metaphors, and sooner or later he 
will produce one or more poems that seem to be at the centre of that structure. These poems are in the formal sense his mythical poems, and they are for the critic the imaginative keys to his work. Such poems (...) enrich not only our poetic experience but our cultural knowledge as well, and as time goes on they become increasingly the only form of knowledge that does not date and continues to hold its interest for future generations. (1971, p.179)

We can further qualify this statement by adding that Page, in her response to our natural and historical environment, has not only enriched our "poetic experience" as readers and our "cultural knowledge" as Brazilians. She has also sharpened and deepened them for, by making "Brazilian Fazenda" a metaphor for the fundamental unity of life and thus for an intense poetic, cultural, and above all transcendental experience, she has made us much more keenly aware of the poetic possibilities of our own fascinating environment and cultural background. ${ }^{10}$

\section{Notes}

1 "That which makes of a given work a work of literature" (JAKOBSON apud Preminger, 1101).

${ }^{2}$ From January 1957 to August 1959, when Rio de Janeiro was still the capital of Brazil.

${ }^{3}$ The coffee farm in particular, which helped to expand human occupation in the states of Rio de Janeiro, São Paulo and Minas Gerais, had its period of greatest opulence in the 19th century, due to a considerable extent to the use of slave labor. The coffee plantation owners became the social and political elite of the country either as "coffee barons", as important political figures, cabinet ministers or senators of the Empire. Their wealth manifested itself not only in their elegant mansions, but also in their bringing European culture to theaters built in the new cities in the hinterland of the state of São Paulo.

${ }^{4}$ According to Leech, "it is the main stressed syllable of a word which generally carries the alliteration, not necessarily its initial syllable".

${ }^{5}$ According to Leech, the "tenor" of a metaphor is that which is actually under discussion and the "vehicle" is the image or analogue in terms of which the tenor is represented. As metaphoric transference can only take place if some likeness is 
perceived between tenor and vehicle, the third notional element of metaphor is the "ground" of the comparison.

${ }^{6}$ Please refer to Page's drawing of this fazenda in Brazilian Journal (edited by Suzanne Bailey and Christopher Doody). Erin: The Porcupine's Quill, 2011, p. 74. Page's description also brings to mind Cândido Portinari's 1939 painting "O lavrador de café" (The coffee farm hand) at MASP (Museu de Arte de São Paulo), which portrays a black laborer on a coffee plantation at the beginning of the 20th century. Standing in the foreground, with a hoe in his hands, he is gazing at the coffee bushes stippling "the lovely, undulating land" in the background. It is one of Portinari's most famous paintings, and representative of his interest in this national theme. Page was not only acquainted with his work, as mentioned several times in her Journal, but even sat beside him during a dinner party.

${ }^{7}$ Page and her husband were visiting the dairy with their hosts. As the remark preceding the quotation explains, "We also saw the equipment used for artificial insemination - and there, under a microscope, for the edification of the men, some semen".(p.45).

${ }^{8}$ Reminding us that Surrealism is one of the traditions out of which Page's poetry grows, as mentioned in the introductory notes.

${ }^{9}$ This dominance can be better evaluated by following a brief outline of the History of Brazil: Colonial Brazil comprises the period from its discovery in 1500 by Pedro Álvares Cabral until 1815, when Brazil was elevated to a kingdom alongside Portugal as the United Kingdom of Portugal, Brazil and the Algarves. During these three centuries, the economic exploration of the land was based on the extraction of "pau-brasil" (brazilwood) in the16th century, on sugar production from the 16 th to the 18th centuries, and on gold and diamond mining in the 18th century. African slaves furnished most of the working force of the Brazilian economy. With the coming of the Portuguese royal family to Brazil, in 1808, fleeing from the Napoleonic invasion of Portugal, Brazil became the seat of the Portuguese colonial Empire. When D. João VI returned to Portugal in 1821, he left his eldest son Pedro to rule Brazil. After declaring independence on September 7th, 1822, Dom Pedro was acclaimed as the first Emperor of Brazil on October 12th. Pedro I abdicated on April 7th 1831 in favor of his five-year-old son, Pedro II, in order to depart for Europe to restore his daughter to the Portuguese throne. After a weak Regency period while he was a minor, D. Pedro II, once he was declared of age, managed to bring peace and stability to the country, which gradually became an emerging international power.

According to historian Boris Fausto, "coffee and slavery, in the states of Rio de Janeiro and São Paulo, financed the Empire and bound the elite together during the 19th century. However, with the end of the trans-Atlantic slave trade in the 1850s" (Reviews in History n. 146), slavery was gradually restricted, until it was abolished in 1888 by Princess Isabel, Pedro II's daughter. The Imperial Period thus lasted from 1822 to 1889, when Brazil was proclaimed a Republic. Fausto also emphasizes that "Brazil is unique in the Americas in that independence from the mother country was 'presided' over by the heir to the metropolitan throne. Perhaps this also accounts for the survival of 'colonial' institutions - monarchy, plantation and slavery - and national unity" (Reviews in History, n. 146) in the 19th century . 
10 P.K.Page's e-mail concerning my presentation of this paper during the VI International Congress of ABECAN : Transculturalisms is in honor of her memory.

Subject: Re: Brazilian Fazenda

Date: Mon, 10 Nov 2001 11:07:00 -0800

From: "P.K.Page" octogen@home.com

To: turbo@ipnet.com.br>

Dear AUTOR, The e-mail came through loud and clear this time and I am delighted that it did as I was greatly interested.

First, I am astonished by your sensitivity to my language. Critics today seem so intent upon meaning that they are inclined to forget that much of the meaning is in the language itself. A kind of meaning beyond meaning.

More importantly, I was surprised by the richness you pulled from the poem, the layers beneath its surface, and how deeply you were able to mine seams I didn't know were there. As I am not a Catholic I was astonished to realize how much Catholic imagery and symbolism the poem contained. All of which re-inforces my belief that a poet is only a vehicle. On good days a better vehicle than on bad days, but a vehicle non-the-less.

Your close reading of my poem has given me great pleasure and I am especially delighted with the circularity of it all - that my pleasure in your beautiful country fifty years ago has given you pleasure today, and that you in turn....

I thank you most sincerely and hope your paper is as well received in academic circles as it has been by me.

Best wishes and warm regards. PKP

\section{Works Cited}

CHEVAliER, J. \& GHEERBRANT, A. Dictionnaire des Symboles. Paris: Seghers, 1974. vol. 4.

CIRLOT, J. E. Dictionary of symbols. London: Routledge \& Kegan Paul, 1971.

FAUSTO, B. A Concise History of Brazil. Cambridge: Cambridge University Press, 1999. URL: http://www.history. ac.uk/reviews/review/146. Date accessed: 10 February, 2014.

FERGUSON, G. Signs \& Symbols in Christian Art. London: Oxford University Press, 1972. 
FRYE, N. The Bush Garden. Essays on the Canadian Imagination. Toronto: Anansi, 1971.

JAKOBSON, R. "Linguistics and Poetics”. IN: Style in Language. Ed. Thomas A. Sebeok. Cambridge: The M.I.T. Press, 1971. 350-377.

LEECH, G. N. A Linguistic Guide to English Poetry. London: Longman, 1969.

ORANGE, J. P.K.Page and Her Works. Toronto: E.C.W. Press, 1987.

PAGE, P. K. Brazilian Journal. Toronto: Key Porter Books, 1997.

The Hidden Room. Collected Poems, vol. 2. Erin:

The Porcupine's Quill,

1997.

. Letter to Sigrid Renaux. June 29, 2001.

PREMINGER, A., ed. Princeton Encyclopedia of Poetry and Poetics. Princeton: Princeton University Press, 1974.

RICOEUR, P, "The Metaphorical Process as Cognition, Imagination, and feeling".IN: On Metaphor. Ed. Sheldon Sacks. Chicago: The University of Chicago Press, 1979.

SHKLOVSKY, V. Theory of Prose. Elmwood Park: Dalkey Archive Press, 1990.

TOYE, W. ed. The Oxford Companion to Canadian Literature. Toronto: Oxford University Press, 1983. 
VRIES, A. de. Dictionary of Symbols and Imagery. Amsterdam: North-Holland, 1974.

WORDSWORTH, W. "Preface to Lyrical Ballads". The Oxford Anthology of English Literature II. New York: Oxford University Press, 1973. 



\title{
ALGUMA POESIA E A TÉCNICA
}

\section{'SOME POETRY' AND THE TECHNIC}

\author{
João Batista SANTIAGO SOBRINHO ${ }^{1}$ \\ a rua acabou, quede as árvores? a cidade sou eu \\ a cidade sou eu \\ sou eu a cidade \\ meu amor. \\ Carlos Drummond de Andrade, 2012, p.102
}

\begin{abstract}
Resumo: Sempre encontramos na poesia de Carlos Drummond de Andrade uma preocupação crítica com os rumos civilizacionais. Este texto pretende, pois, expor, no primeiro livro do poeta mineiro, Alguma poesia, publicado em 1930, uma gênese dessa preocupação. Para colocarmos em evidência essa temática, nos utilizaremos da crítica literária e filosófica, bem como de alguns poemas drummondianos, nos quais o poeta problematiza, ao longo de sua poesia, uma tensão entre a técnica e a vida.
\end{abstract}

Palavras-chave: poesia, técnica, filosofia, crítica literária.

Abstract: We always found in the poetic of Carlos Drummond de Andrade - a brazilian poet from Minas Gerais - a criticism upon the process of civilization. In this paper, we focus on the first book of the poet, intitled "Some Poetry", first published in 1930, so to say, the foundation of his speculations. To approach this subject we dialogue with the literary and philosophical criticism and also with his poems. In a way,

\footnotetext{
${ }^{1}$ Professor, Departamento de Linguagens e tecnologias, Centro federal de Educação Tecnológica de Minas Gerais, CEFET-MG, 30421169, Belo Horizonte, Minas Gerais, Brasil e joaoliter@hotmail.com
} 
Drummond's poetic problemizes the tensions between technic and life.

Keywords: poetry, technic, philosophy and literary criticism.

A poesia drummondiana, desde o início, problematizou a relação do homem com o meio. Por essa razão, Manuel Bandeira dirá que Carlos Drummond é o poeta da "emoção social", seara que, segundo Manuel Bandeira, ele só atingiu em meia dúzia de poemas (BANDEIRA, 1984, p.102). E é justamente em meio a essa emoção que perscrutamos, na poesia de Drummond, a presença da técnica, da qual daremos notícia conceitualmente um pouco mais à frente. A expressão de Bandeira possui a delicadeza de não enquadrar o poeta mineiro para além da verdade poética, essa grande estrela no firmamento da linguagem de Drummond. Nesse sentido, este texto irá explorar, no livro Alguma poesia, o fio nascente e tentacular dessa preocupação com os rumos civilizacionais, que se estenderá, por fim, a toda escritura de Carlos Drummond de Andrade. Para tanto, nos utilizaremos da filosofia, mormente aquela envolvida com a crítica à técnica, bem como da crítica literária que contribua para a visualidade temática que ensejamos. Este texto é fruto das pesquisas que temos realizado no grupo de pesquisa "Literatecnica: estudos sobre literatura, outras artes e técnica”, do Centro Federal de Educação Tecnológica de Minas Gerais (Cefet-MG).

O livro Alguma poesia pertence à geração de 1930, no entanto, muitos dos seus poemas foram escritos ao longo dos anos 20 do século passado, portanto, na fase "heroica do modernismo" e sob forte influência das vanguardas europeias e todo o aparato estéticosocial que àquele momento hiperbólico se firmava. Drummond, a exemplo de outros modernistas, não se deixa contaminar pelo futurismo de Filippo Tommazo Marinetti, expressão estética das vanguardas mais entusiasta da técnica.

Marinetti, ideólogo e poeta do futurismo, de acordo com Nikos 
Stangos, "queria que as artes demolissem o passado e celebrassem as delícias da velocidade e da energia mecânica" (STANGOS, 2000, p.85); com esse pathos técnico, Marinetti logo se encaminharia para a expressão máxima da técnica em sua época, o fascismo e o nazismo e, consequentemente a guerra.

Ao tratar sobre a estetização da vida política no texto "Estética da guerra”, em 1935/1936, Walter Benjamin, fará duras críticas às ideias de Marinetti:

A política se deixou impregnar, com d'Annunzio, pela decadência, com Marinetti, pelo futurismo, e com Hitler, pela tradição de Sachwabing [bairro boêmio de Viena]. Todos os esforços para estetizar a política convergem para um ponto. Esse ponto é a guerra. A guerra e somente a guerra permite dar um objetivo aos grandes movimentos de massa, preservando as relações de produção existentes. Eis como o fenômeno pode ser formulado do ponto de vista político. Do pondo de vista técnico, sua formulação é a seguinte: somente a guerra permite mobilizar em sua totalidade os meios técnicos do presente, preservando as atuais relações de produção. (BENJAMIN, 1985, p.195; grifos do autor).

Benjamin enfaticamente combate a expressão de Maninetti: "a guerra é bela", que se repete em um manifesto do futurista sobre a guerra colonial da Etiópia.

Embora saibamos que Alguma poesia não traduz de maneira intensa a "emoção social", é no âmbito dessa mirada drummondiana que encaminharemos nossa investigação de uma poesia que nasce justamente no início do "século da guerra", ou "sob o paradigma da guerra”, na visão de Alain Badiou, que, no livro O século (2007, p.60), interpreta o século XX como aquele mais violento da história da humanidade. Ainda de acordo com o filósofo, depois de uma largada luminosa de "criatividade polimorfa", semelhante à Renascença florentina ou ao "Século de Péricles", o século XX se estabelece como longa tragédia, marcada sobretudo por uma efervescência criativa, com vistas a criar um "novo homem", e "criar um novo homem 
equivale sempre a exigir que o homem seja destruído" (BADIOU, 2007, p.21). Para Badiou,

0 projeto do homem novo é nesse sentido projeto de ruptura e de fundação que sustenta, na ordem da história e do Estado, a mesma tonalidade subjetiva que as rupturas científicas, artísticas, sexuais do início do século. É, portanto, possível afirmar que o século foi fiel ao seu prólogo. Ferozmente fiel. (BADIOU, 2007, p.21).

Badiou quer dizer que o século da guerra, em vista do que anunciava em seu prólogo, o intento de criar um novo homem, resultou num processo de violência sem precedentes cujo ápice concentra-se, pode-se dizer, no projeto de estetização proposto e colocado em prática pelo Nacional Socialismo alemão.

A poética drummondiana assume postura corrosiva quanto ao "novo homem", encontrando forte apelo, por exemplo, no poema "Especulações em torno da palavra homem" (DRUMMOND, 2002, p.428), do livro A vida passada a limpo, de 1958, poema que se encerra com a pergunta "mais que coisa é o homem?", retomada no poema "Novo homem", do livro Versiprosa, de 1967:

\footnotetext{
"Nove meses eu?

Nem nove minutos."

Quem já concebeu

melhores produtos. (ANDRADE, 2002, p.638).
}

A "coisificação" do "novo homem" fica evidente quando o poeta o chama de "produto", rimando com o tempo de fabricação ajustado ao timing de produtividade mercantil. 0 poema se constrói tensionando o velho homem, "defeituoso", o homem "antigório", com o homem novo, e termina com os versos:
eis que o homem feito
em laboratório
sem qualquer defeito
como no antigório, 
acabou com o homem.

Bem feito. (ANDRADE, 2002, p.640).

Para acabar com o homem velho, a técnica, o século XX, atendendo ao seu "prólogo", lançou-se com avidez no projeto de criação do homem novo. 0 poema drummondiano, como não podia deixar de ser, encerra sua jornada de maneira irônica, com a expressão dúbia, aberta: "Bem feito". Bem, no sentido, de "bens" e de "coisa", do poema "Especulações em torno da palavra homem", mercadoria bem acabada, bem feita; e "Bem feito!" no sentido do sarcasmo machadiano de "ao vencedor, as batatas", ao fim, tem-se o que se fez por merecer.

Manuel Bandeira, em Itinerário de Pasárgada, comentando o que ele chama de "emoção social", afirma:

intenso é meu desejo de participação, mas sei, de ciência certa, que sou um poeta menor. Em tais altas paragens só respira à vontade entre nós, atualmente, o poeta que escreveu o Sentimento do mundo e Rosa do povo. (BANDEIRA, 1984, p.102).

De muitas maneiras, nossa leitura sobre Alguma poesia advém de uma mirada sobre os dois livros citados nesse recorte bandeiriano e, para dar sequência ao nosso olhar sobre a poesia de Drummond, também a contribuição de Umberto Galimberti para a compreensão do que seja a "técnica" é decisiva. Seu conceito de técnica chama a atenção para a racionalidade, a funcionalidade e a eficiência que, no imaginário social, se assentam como instâncias imprescindíveis e inquestionáveis:

com o termo técnica entendemos tanto o universo do meios (tecnologias), que em seu conjunto compõem o aparato técnico, quanto a racionalidade que preside seu emprego, em termos de funcionalidade e eficiência. (GALIMBERTI, 2006, p.9). 
Ainda, corroborando o conceito de técnica de Galimberti, utilizamos o conceito de "dispositivo" de Giorgio Agamben, que o constrói a partir, por exemplo, dos estudos de Foucault, Heidegger e Marcuse, e o expõe às forças hegemônicas que reforçam a visão tecnocrata do mundo, da qual participam o capitalismo e as instâncias que o sustentam, dando origem àquilo que Agamben chama de "dispositivo" e Heidegger "armação", ou seja, a "máquina que produz subjetivações" (AGAMBEN, 2012, p.46). Assim, o conceito de "dispositivo", para o filósofo italiano, abarca

qualquer coisa que tenha de algum modo a capacidade de capturar, orientar, determinar, interceptar, modelar, controlar e assegurar os gestos, as condutas, as opiniões e os discursos dos seres viventes. (AGAMBEN, 2012, p.40).

Os poemas de Alguma poesia deixam entrever vestígios de uma crítica problemática à técnica, que se acentuará em poemas como "Sentimento do mundo" (DRUMMOND, 2012, p.205), no qual o poeta retrata uma espécie de "campo de guerra" - expressão mais acabada da técnica - em que a vida se transformara; e "A noite dissolve os homens" (DRUMMOND, 2012, p.246), em que o mesmo cenário se repete. Mas, sobretudo, é no livro Rosa do povo, no qual "melancolias, mercadorias" espreitam o poeta, no poema "A flor e a náusea" (DRUMMOND, 2012, p.310), que ocorrerá um dos momentos mais fortes de "emoção social". É esse mesmo poema que traz o nascimento de uma flor que, para além de seu aspecto metalinguístico, é metonímia da natureza, presença intensa no imaginário drummondiano, que, ao longo de toda a sua produção poética, se contrapõe quase sempre ao modelo civilizacional:

Uma flor nasceu na rua!

Passem longe, bondes, ônibus, rio de aço do tráfego.

Uma flor ainda desbotada

ilude a polícia, rompe o asfalto.

Façam completo silêncio, paralisem os negócios, garanto que uma flor nasceu. 
Sua cor não se percebe.

Suas pétalas não se abrem.

Seu nome não está nos livros.

É feia. Mas é realmente uma flor.

(ANDRADE, 2012, p.311).

Naturalmente que a flor, metonimicamente, pode simbolizar a esperança frágil em oposição à "razão instrumental", cujos dispositivos "bondes”, “ônibus”, “tráfego”, “polícia”, “asfalto” exprimem.

Essa condição ulterior da escritura mais incisiva do poeta em relação aos rumos civilizacionais nos obriga a reler Alguma poesia com olhos mais argutos em relação ao tema que propusemos. Em que pese a recolha do poeta no livro Claro enigma, marcado por uma espécie de cansaço agudo ou recusa trágica mediante a ineficácia da luta do homem por um mundo mais justo, a "emoção social" nunca abandonará o poeta. Quase sempre se pode notar esse aspecto na poesia de Drummond, sobretudo na dimensão de um apreço à natureza, cuja menção ocorrerá necessariamente por conta do seu massacre perante o processo civilizatório, ou seja, as forças da técnica que, de acordo com Galimberti, crescem concomitantemente à destruição da natureza. Ressaltamos que não há em Drummond um discurso do inocentação ou da culpabilização, nada escapa à escritura corrosiva do poeta, que compreende que a vida é uma resultante problemática de forças. É o que ele faz ver em poemas como, por exemplo, "Tarde de maio", do livro Claro enigma, quando trata da guerra, misturando-a ao labor de uma subjetividade furiosa que espelha a devastação do mundo:

quando, ao rubor dos incêndios que consumiam a terra, outra chama, não perceptível, e tão mais devastadora, surdamente lavrava sob meus traços cômicos (ANDRADE, 2012, p.596-597).

Vemos, nessa cena de guerra, uma espécie de suma do que seja a técnica, ou seja, ela é uma forma de pensamento - "outra chama”, 
uma força que "surdamente lavrava sob meus traças cômicos" - e não, conforme se imagina em geral, uma dimensão externa ao homem. Em verdade, a técnica é mais "uma visão de mundo", é uma maneira de desvelar o mundo, para usar um termo caro a Heidegger, que afirma que a "a essência da técnica não é, de forma alguma, nada de técnico" (HEIDEGGER, 2008, p.11).

Alguma poesia foi publicado em 1930, edição em 500 exemplares, paga pelo autor. 0 mundo vive, então, um momento extremamente crítico, a crise de 1929. Uma crise, sem precedentes, do capital. 0 poema “Outubro 1930" (DRUMMOND, 2012, p.139) retrata, com ares autobiográficos, já que Drummond participou ativamente da revolução de 1930, que contribuiu para levar Getúlio Vargas ao poder:

de 5 em 5 minutos um ciclista trazia ao Estado-Maior um feixe de telegramas contendo, comprimida, a trepidação dos setores. 0 radiotelegrafista ora triste ora alegre empunhava um papel que era a vitória ou a derrota. Nós descansávamos, jogados sobre poltronas, e abríamos para as notícias os olhos que não viam, olhos que perguntavam. Às 3 da madrugada, pontualmente, recomeçava o tiroteio. (DRUMMOND, 2012, p.139).

O poema em prosa, acima, compõe a segunda estrofe de “Outubro 1930", no entanto, se pode afirmar que é um retrato do século XX, tomando-o já como século da guerra. Sobre esse assunto, Drummond irá falar de maneira mais ou menos íntima numa prosa com Ary de Andrade, que será registrada no texto produzido a partir de uma conversa entre esses dois gauches: "O mundo de apósguerra”, do primeiro volume da Coleção Fortuna Crítica, dirigira por Afrânio Coutinho. Ary de Andrade pergunta a Drummond, "Como lhe parece o mundo de após-guerra?", tomando como referência a Segunda Guerra Mundial. Entre o que disse o poeta sobre o pósguerra, recolhemos a seguinte passagem:

Para que se pudesse dizer que este conflito não foi em vão 
e veio beneficiar a humanidade, seria preciso que nesse amanhã, de que estamos ainda num sombrio princípio de aurora, trouxesse melhores condições de vida, habitação, cultura, subsistência para todos os homens, sem distinções nem discriminações, quaisquer que elas fossem. Que às bibliotecas fosse permitido o acesso aos que tem os pés descalços (ou antes, que não houvesse mais pés descalços no mundo...) mas, esquecidos das vísceras, têm fome e sede de saber. Que os museus não fossem só para privilegiados capazes de apreciá-los pelo seu nível de cultura. Que os homens que nada possuem pudessem frequentar esses lugares como podem agora viajar nos bondes de segunda classe. Porque, nas atuais condições econômicas vigentes na maior parte da superfície da terra, e apesar do que se diga em contrário, a cultura continua a ser um privilégio de classe e de casta. (ANDRADE, 1977, p.32).

No trecho acima, a "emoção social" salta aos olhos. Não só por sua lucidez de análise e seu diálogo com a própria poética drummondiana, mas por sua atualidade. Drummond se utiliza da pergunta sobre o pós-guerra para trazer sua reflexão para o âmbito da guerra cotidiana, que, afinal, constitui o próprio viver mediante as forças político-sociais que nitidamente privilegiam as classes mais abastadas. E, para o poeta, a guerra - expressão radical da técnica - resultaria em nada caso não pudesse ela mudar as condições de desigualdade social.

Isto posto, dentre os poemas do livro Alguma poesia, cuidaremos de problematizar apenas alguns que fizerem direta ou indiretamente alguma alusão à técnica.

Em princípio, a presença da técnica ocorre apenas como ilustração do cotidiano, donde o poeta, acolhendo um preceito modernista, extrai sua poesia. Isso não quer dizer uma ausência de problematização do "eu lírico" em relação à técnica. Se "bonde”, no "Poema das sete faces", é espaço para o voyeurismo drummondiano, posteriormente, a presença desse dispositivo será acrescida de suas razões, digamos, técnicas. Nesse poema, é notória a dimensão 
do corpo que, na perspectiva que adotamos, se torna importante, em razão de uma mirada pós-orgânica que torna o corpo obsoleto para o "ideário fáustico da tecnociência contemporânea", conforme, Paula Sibilia (2002, p.63), por exemplo. Esse ideário fáustico consistiria num pacto, numa aceitação incondicional às promessas da técnica. Certamente, não é isso que vemos em Drummond. Embora se possa perceber que, ao fim, o corpo é a única dimensão da existência em que o eu lírico drummondiano se veja dividido. Essa divisão é exposta nos versos do poema "Missão do corpo", do livro póstumo, Farwell, do qual recortamos as seguintes passagens:

\author{
Em ti me sinto dividido, campo de batalha \\ sem vitória para nenhum lado \\ e sofro e sou feliz \\ na medida do que o acaso me oferece \\ Será mesmo acaso, \\ será lei divina ou dragonária \\ que me parte e reparte em pedacinhos? \\ Meu corpo, minha dor, \\ meu prazer e transcendência, \\ és afinal meu ser inteiro e único. \\ (ANDRADE, 2002, p.1418-1419).
}

Essa declaração de que o corpo é o "ser inteiro e único" do poeta nos parece exemplar no sentido de que essa é a instância da qual tudo o mais se deflagra, o campo de batalha primeiro, donde resulta, por assim dizer, o mundo no qual ocorrem as "outras" batalhas, que são, por sua vez, resultado das projeções do corpo - a dimensão da "guerra" no significante "batalha", problematizada também no poema "Tarde de maio", conforme vimos, anteriormente, neste texto.

Como desdobramento desse sentimento tão drummondiano do estar no mundo - no mundo que se desvelava naquele século $\mathrm{XX}$-, encenam-se as progressivas mudanças cuja ambiguidade, no sentido de um encantamento/desencantamento, explora o eu lírico no poema "A rua diferente": 
Na minha rua estão cortando as árvores

botando trilhos

construindo casas.

Minha rua acordou mudada.

Os vizinhos não se conformam.

Eles não sabem que a vida

tem dessas exigências brutas.

Só minha filha goza o espetáculo

e se diverte com os andaimes,

a luz da solda autógena

e o cimento escorrendo nas formas.

(ANDRADE, 2012, p.78).

Há no poema "A rua diferente" a primeira constatação mais contundente de que as mudanças festejadas no projeto modernista, cujo exemplo maior, no Brasil, à época, era a cidade de São Paulo, não goza de tanto prestígio assim aos olhos do povo e do eu lírico apesar da "filha" deste gozar o "espetáculo". E, apesar da aparente serenidade com que mostra saber que a vida tem suas "exigências brutas", o poema deixa entrever um grau de insatisfação que se pode inferir como sendo também do eu lírico. 0 mesmo clima, agora sem nenhuma intervenção do eu lírico, ocorre no poema "Construção":

Um grito pula no ar como um foguete.

Vem da paisagem de barro úmido, caliça e andaimes hirtos.

O sol cai sobre as coisas em placas fervendo.

0 sorveteiro corta a rua.

E o vento brinca nos bigodes do construtor. (ANDRADE, 2012, p.62).

Esse poema, que antecede na enunciação e no enunciado, o poema "Uma rua diferente" - este editado em 1928 e aquele em 1925 -, tem uma marcação mecânica, que os pontos finais, a cada verso, enfatiza. De resto, o poeta apenas observa e constata, como um fotógrafo, um flaneur, os acontecimentos intermináveis do devir civilizacional, como a imagem final do poema, "e o vento 
brinca nos bigodes do construtor", metalinguisticamente faz ver, pois o construtor, pode-se também inferir é o eu lírico que constrói as imagens, que constrói o poema.

Em outro caso, o poema "Cidadezinha qualquer" se opõe, naturalmente, a uma das dimensões mais caras à técnica, a velocidade, esta que, para Paul Virilio, no livro $A$ velocidade de libertação (2000) representa uma espécie de libertação da matéria:

\author{
Casa entre bananeiras \\ mulheres entre laranjeiras \\ pomar amor cantar \\ Um homem vai devagar \\ Um cachorro vai devagar \\ Um burro vai devagar \\ Devagar... as janelas olham. \\ Eta vida besta, meu Deus. \\ (DRUMMOND, 2012, p.109).
}

A vagareza se notabiliza por oposição implícita à velocidade dos grandes centros urbanos. Mas, mesmo aí, a técnica, com seu projeto totalitário, já atravessa o sertão, e, se antes o fazia de "carroça", urge fazê-lo de trem, ou seja, à luz de uma modernização que acerte os ponteiros brasileiros com o resto do mundo, não apenas no âmbito estético, mas também tecnológico. Não estamos afirmando que o poema drummondiano aventa essa proposta, mas ela é frequente ao momento em que Drummond escrevia Alguma poesia e ressoa em sua produção na condição revelada mais tarde pelo eu lírico, sobretudo quando este afirma, epigramaticamente, no poema explicação: "no elevador penso na roça,/ na roça penso no elevador". Está aí ou, segundo John Gledson, no livro Poesia e poética de Carlos Drummond de Andrade, seu "provincianismo e seu modernismo" (GLEDSON, 1981, p.59): o provincianismo estaria para "cidadezinha qualquer", ao passo que o cosmopolitismo, explícito, por exemplo, pela presença dos gadgets que traduzissem uma atualização do país com o resto do mundo, estaria para o "modernismo". Mas, ainda de acordo com Gledson, em Drummond, o provincianismo é desconfiado e crítico 
da metrópole (Paris), que Belo Horizonte copia, com seus jardins e arquiteturas, e, nesse sentido, o poeta capta o sentimento oscilante que normalmente nos toma mediante a técnica:

Ao irmos da "roça" para o "elevador", descobrimos que a própria escolha da imagem resume muita coisa. É, sobretudo, o aspecto moderno e mecânico da cidade que interessa ao poeta: quaisquer que fossem as possíveis razões sociológicas deste interesse, não podemos duvidar de sua importância. 0 automóvel é assunto de dois poemas irônicos, "Cota zero" (0. C. p.71) e "Sinal de apito" (0. C. p.68); e, "Nota social", o poeta melancólico está cercado de automóveis, máquinas, fotografias e elevadores; "Poema do jornal" (O. C. p.63) comenta as novas máquinas de construção. Num sentido mais metafórico, também, há uma forte tendência a ver a sociedade urbana no seu aspecto mecânico. Poemas como "Sociedade" (0. C. p.73), "Família" (0. C. p.69), "Moça e soldado" (0. C. p.70), e "O que fizeram do natal" (O. C. p.61) mostram seres humanos que obedecem as regras sociais como autômatos. (GLEDSON, 1981, p.68).

Nesse sentido, concordamos com a postura de Gledson, ou seja, Drummond, entre o "elevador" e a "roça", se mantém ironicamente gauche, sem afirmar decididamente ante essa ou aquela dimensão da vida, muito embora não deixe de traduzir uma crítica dura quanto aos rumos civilizacionais, que o "elevador" alegoriza, como esperamos explicitar neste texto.

Essa "demora" da "vida besta" da pequena cidade desaparece, agora por completo, em meio de cabos de fibra ótica ou wireless, "atualizando" toda a gente com a velocidade, digamos, em tempo real. A sensação do tempo veloz é experimentada por praticamente todos. Sobre isso, afirma Paul Virilio: "O tempo mundial é o mundo do tempo único e acabado, que ameaça ter consequências dramáticas sobre o nosso sentimento de realidade" (VIRILIO, 2000, p.194). Esse mesmo filósofo nos lembra a origem da realidade virtual que proporciona experiências em tempo real:

É preciso ver que a guerra é que trouxe a realidade 
virtual: é o desenvolvimento dos simuladores de voo para a US Air Force (na intensão de economizar a gasolina dos bombardeios, bem como vidas humanas) que esteve na base das pesquisas sobre os ciberespaços que são, doravante, objetos lúdicos. Pouco a pouco, desenvolveram tecnologias de simulação de voo dentro do quadro de antecipações da guerra nuclear: fizeram jogos de guerra, war games, que eram jogos não de garotos, mas de estados-maiores, e essa realidade virtual substituiu aos poucos a realidade das manobras terrenas. (VIRILIO, 2000, p.195).

A razão que está por trás da lógica da guerra é instrumental, não visa à outra coisa senão reduzir os custos e aumentar os lucros. 0 termo ironicamente utilizado por Virilio, "economizar", não deixa dúvidas quanto ao caráter racional-instrumental que gerou a descoberta do virtual. Tudo isso, monitorado pela ideia de eficácia, reduz a própria vida aos dispositivos.

O poema, "Cidadezinha qualquer", também nesse sentido, para além da blague, do humor, do poema-piada, se ressignifica para ser uma espécie de crônica de um outro tempo, cuja lentidão e graça, por si mesmas, se opõem à vontade de velocidade da técnica.

No poema intitulado "Europa, França e Bahia", o eu lírico vê a Europa conforme em geral nos viam, ao sonhar que os europeus é que são "exóticos":

Meus olhos brasileiros sonhando exotismo.
Paris. A torre Eiffel alastrada de antenas como um
caranguejo.
O cais bolorento de livros judeus
e a água suja do Sena escorrendo sabedoria. (ANDRADE, 2012, p.64).

São os versos iniciais do poema, e são extremamente corrosivos ao desancar o dispositivo iluminista, a torre Eiffel, comparando-a a um caranguejo, que, no imaginário popular, anda para trás. E logo se seguem imagens decadentes relativas ao ocidente judaico, 
expressas num porto "bolorento", "cais" de "livros judeus", e fecha a estrofe com a sabedoria "suja" que escorre do rio Sena. Tratase de um poema completamente desencantado com os rumos civilizacionais do Ocidente. Em seguida, o eu lírico afirma:

0 pulo na Mancha num segundo.

Meus olhos espiam olhos ingleses vigilantes nas docas.

Tarifas bancos fábricas trustes craques.

Milhões de dorsos agachados em colônias longínquas formam um tapete

[para Sua Graciosa Majestade Britânica pisar. E a lua de Londres como um remorso.

(ANDRADE, 2012, p.64).

A presença da Bahia, metonímia de Brasil, nos faz pensar num outro poeta cuja "ira", talvez inda mais corrosiva, recai sobre essa relação de subserviência da colônia para com a Europa. Estamos nos referindo a Gregório de Matos e ao poema que ficou conhecido nesses "tristes trópicos" como "Triste Bahia". Sobre ele, os estudos de Alfredo Bosi, na Dialética da colonização (1992), no capítulo “Do antigo estado à máquina mercante”, e de José Miguel Wisnik, no livro Poemas escolhidos de Gregório de Matos (2010), para ficar apenas nesses dois, traduzem com agudeza o clima crítico que o poeta barroco conclama, e que não é outro senão este mesmo que Drummond reencena em relação à "máquina mercante" dos anos de 1930. Nesse encontro entre os dois poetas, o "sagaz Brichote", nome dado aos estrangeiros (HOUAISS, 2001, p.512) por Gregório de Matos, equivale aos "olhos vigilantes dos ingleses nas docas" de que fala Drummond. Em seguida, o eu lírico faz uma suma do que tem sido historicamente a relação da Bahia/Brasil com os dispositivos civilizacionais, e lá em Gregório, como aqui em Drummond, a atualidade dos versos saltam aos olhos.

Além disso, em que pesem outras possíveis representações da lua na obra drummondiana, para o que remetemos, por exemplo, ao artigo de Vivaldo Andrade dos Santos, “O corpo que não morreu 
especialmente para nos comover" (REVISTA USP, 2006, p. 181192), que traz uma análise do corpo no livro Alguma poesia. No sentido que perscrutamos nos versos acima, podemos inferir que se trata de uma ironia, a personificação da lua, para dizer de uma impossibilidade de remorso por parte de dispositivos e pessoas (como dispositivos) imperantes sob a lua: tarifas, bancos, fábricas, trustes, craques, e, especialmente, "Sua Graciosa Majestade Britânica", os quais capitaneiam o processo civilizatório. "Europa, França, Bahia", ainda alude, de maneira explícita, a dispositivos de guerra, ao se referir, por exemplo, aos "submarinos" (DRUMMOND, 2012, p.64) e ao próprio Mussolini (DRUMMOND, 2012, p.65), nesse poema que, entre outras perspectivas, aborda a relação de exploração mercantilista existente entre a metrópole e a colônia, entre, vale dizer, a "Europa" e a "Bahia".

Assim, este texto consistiu em apontamentos para um estudo mais aprofundado das questões que expusemos, quais sejam, as dimensões problemáticas da relação da poesia drummondiana com a técnica. Dimensões que se viram exemplificadas, a partir de uma leitura, mesmo que fragmentada, de uma "emoção social" que passa pelas considerações do poeta, advindas do corpo, donde se elabora o pensamento que conduz o homem ao processo civilizatório, dentre o qual a dimensão bélica se destaca. 0 poeta protagoniza, então, e corrobora, uma máxima heideggeriana, aquela de que a técnica não é neutra, e tampouco é apenas uma dimensão do técnico, do qual se faria bom ou mau uso. Dessa forma, o poeta insere o homem, desde dentro, desde o início de sua jornada escritural, como um dispositivo propulsor da tragédia social em que se vê encalacrado, sem, contudo, perder a dimensão corporal, espaço único e problemático de uma transcendência mundana em cuja batalha, por fim, o homem, em "amor problemático, se dissolve na cidade, que é ele mesmo. 


\section{Referências bibliográficas}

AGAMBEN, Giorgio. 0 que é o contemporâneo? e outros ensaios. Tradução de Vinícius Nicastro Honesco. Chapecó, SC: Argos, 2012.

ANDRADE, Carlos Drummond de. Poesia 1930-62 - de Alguma poesia a Lição de coisas. Edição crítica organizada por Júlio Castañon Guimarães. São Paulo: Cosac Naify, 2012.

ANDRADE, Carlos Drummond de. Poesia completa. Rio de Janeiro: Nova Aguilar, 2002.

ANDRADE, Carlos Drummond de. 0 mundo de após-guerra. Entrevista a Ary de Andrade. In: BRYNER, Sônia (organização). Carlos Drummond de Andrade. Rio de Janeiro: Civilização Brasileira, 1977 (Coleção Fortuna Crítica, 1). p. 30-36.

BADIOU, Alain. 0 século. Tradução de Carlos Felício da Silveira. São Paulo: Ideias \& Letras, 2007.

BANDEIRA, Manuel. Itinerário de Pasárgada. Rio de Janeiro: Nova Fronteira, 1984.

BOSI, Alfredo. Dialética da colonização. Rio de Janeiro: Companhia das Letras, 1992.

BENJAMIN, Walter. Magia, técnica, arte e política. São Paulo: Brasiliense, 1985.

GALIMBERTI, Umberto. Psiche \& techne: o homem na idade da técnica. Tradução de José Maria de Almeida. São Paulo: Paulus, 2006. 
GLEDSON, John. Poesia e poética de Carlos Drummond de Andrade. São Paulo: Duas Cidades, 1981.

HOUAISS, Antônio. Dicionário da língua portuguesa. Rio de Janeiro: Objetiva, 2001.

REVISTA USP, São Paulo, n.69, p. 181-192, mar./maio 2006.

SIBILIA, Paula. 0 homem pós-orgânico: corpo, subjetividade e tecnologias digitais. Rio de Janeiro: Relume Dumará, 2002.

STANGOS, Nikos (organização). Conceitos de arte moderna. Tradução de Álvaro Cabral). Rio de Janeiro: Jorge Zahar Editor, 2000.

VIRILIO, Paul. Velocidade de libertação. Lisboa: Relógio D’água, 2000.

WISNIK, José Miguel (seleção e organização). Poemas escolhidos / Gregório de Matos. São Paulo: Companhia das Letras, 2010. 


\title{
IMAGENS POÉTICAS E PICTÓRICAS DAS CATARATAS DO IGUAÇU E SETE QUEDAS: POESIA E MEMÓRIA
}

Antonio Donizeti da CRUZ ${ }^{1}$

\begin{abstract}
RESUMO: 0 presente artigo visa o estudo das imagens representativas das Belezas Naturais do Paraná, (re) apresentadas pelos escritores, poetas, artistas plásticos, que possibilitem uma reflexão sobre a natureza, sobre a poesia, a pintura, artes visuais, com textos representativos do Estado, bem como as confluências do sentido da arte, da linguagem poética, dos aspectos sociais, míticos e da intertextualidade presentes em imagens poéticas e picturais, fotográficas, visuais, tais como as Cataratas do Iguaçu e Sete Quedas, com estudos nas imagens simbólicas e na valorização de temas interligados às belezas naturais do Paraná, e na valorização de tais imagens presentes nas obras dos poetas, artistas, do Paraná e do Brasil.
\end{abstract}

\section{Imagens poético-aquáticas do Paraná}

Para Octavio Paz, cada civilização é uma metáfora do tempo. Já a imagem do mundo - estrutura inconsciente da sociedade -, nutrida por uma concepção particular de tempo (PAZ, 1991, p. 97) -, se alicerça nas produções culturais, por isso é que ela remete à encarnação de uma presença. É pelo diálogo com o mundo que o

${ }^{1}$ Professor Associado da Universidade Estadual do Oeste do Paraná. Bolsista Produtividade em Pesquisa pela FUNDAÇÃO ARAUCÁRIA - Paraná. 
homem se instaura frente à realidade na qual se insere, ou seja, as imagem do poema é sempre um convite à transmutação de sentido. Nesse sentido, as imagens do tempo e do mundo se interligam. 0 homem é tempo. Se cada época escolhe sua definição de homem, para Octavio Paz, a do nosso tempo é "o homem é um emissor de símbolos" (1991, p. 114).

Conforme Bachelard (1989b), a imagem ao assumir um valor cósmico produz o efeito de um pensamento vertiginoso. Uma tal imagem-pensamento, um tal pensamento-imagem-frase é uma proeza de expressão. As palavras vão além do pensamento. Toda poesia é retorno, começo. As imagens-frases que são um colorido especial, que contam as chamas vegetais são igualmente ações polêmicas. Com os poetas contemporâneos, entramos no reino da poesia brusca, poesia de ruptura, "uma poesia que não conversa, mas que sempre quer viver em primeiras palavras. Portanto, é preciso escutar os poemas como palavras ditas pela primeira vez. A poesia é admiração, exatamente ao nível da palavra, na palavra e pela palavra" (BACHELARD, 1989b, p. 79).

Em relação às forças imaginantes da nossa mente, Bachelard salienta que elas se desenvolvem em duas linhas bem diferentes. Umas encontram seu impulso na novidade; divertem-se com o pitoresco, com a variedade, com o acontecimento inesperado. A imaginação que elas vivificam tem sempre uma primavera a descrever. As outras forças imaginantes escavam o fundo do ser e, ao mesmo tempo, querem encontrar no ser, o primitivo e o eterno. Dominam a época e a história.

Para Gilbert Durand, o imaginário é "o reservatório concreto da representação humana em geral, onde se vem inscrever o trajeto reversível que, do social ao biológico, e vice-versa, informa a consciência global, a consciência humana" (2003, p. 65). A imaginação, por sua vez, é uma forma de pensamento, a qual não necessita de um processo descritivo e que se utiliza da lógica dos símbolos, isto é, a mente se utiliza de imagens quando não consegue representar de maneira direta o mundo por meio de uma percepção 
simples ou sensação, conforme assevera Durand. Salienta ainda que a imaginação se define como uma reação defensiva da natureza contra a representação da inevitabilidade da morte, por meio da inteligência. A função da imaginação é, acima de tudo,

uma função de 'eufemização', mas não é simplesmente ópio negativo, máscara que a consciência ergue diante da hedionda figura da morte, mas pelo contrário, dinamismo prospectivo que através de todas as estruturas do projeto imaginário, tenta melhorar a situação do homem no mundo. (DURAND, 1995, p. 99. Grifo do autor).

Dessa forma, a imaginação simbólica é um elemento de equilíbrio psicossocial, sociológico, psíquico e biológico. Assim, a imaginação e memória são elementos que balizam as obras dos poetas e artistas do Paraná e Brasil - ao (re)apresentarem as imagens das belezas naturais do Estado do Paraná, uma vez que elaboram uma poiesis alicerçada em um mundo de significações, com suas imagens simbólicas com as quais realizam um fazer poético e construção imaginária que remetem à condição humana e à natureza: transitoriedade e permanência. 0 conjunto dos textos poéticos e pictóricos forma uma constelação de textos-imagens que visam preservar, compartilhar os saberes e a construção de uma Memória de valorização do patrimônio do Paraná e Brasil, com vistas à interação dos contextos a partir das Belezas Naturais do Estado - Cataratas do Iguaçu e Sete Quedas - convertidas em "vozes" e "imagens" que visam compor um quadro mais amplo de uma "memória do mundo". Ou como diz o poeta e pensador Octavio Paz, "a poesia é a Memória feita imagem e esta convertida em voz. A outra voz não é a voz do além-túmulo: é a do homem que está dormindo no fundo de cada homem" (1993, p. 144. Grifo do autor).

Para o filósofo Gaston Bachelard, o homem sonha através de uma personalidade de uma memória muito antiga. Ele mira-se em seu passado, pois toda imagem para ele é lembrança. Nesse 
sentido, memória e imaginação não se deixam dissociar, ou seja, ambas trabalham para o aprofundamento mútuo. Elas constituem, na ordem dos valores, uma união da lembrança com a imagem. "Uma memória imemorial trabalha numa retaguarda do mundo. Os sonhos, os pensamentos, as lembranças formam um único tecido. A alma sonha e pensa, e depois imagina" (BACHELARD, 1993, p. 181).

Durand salienta que a memória tem "o caráter fundamental do imaginário, que é ser eufemismo, ela é também, por isso mesmo, antidestino que se ergue contra o tempo" (1997, p. 405. Grifo nosso.). É ainda "poder de organização de um todo a partir de um fragmento vivido". Essa potência "reflexógena" é "o poder da vida", que por sua vez, é capacidade de reação, de regresso. A organização que faz com que uma parte se torne "dominante" em relação a um todo é a negação da capacidade de equivalência irreversível que é o tempo. Por isso, a memória - bem como a imagem - é a magia dupla "pela qual um fragmento existencial pode resumir e simbolizar a totalidade do tempo reencontrado" (1997, p. 403). 0 ato reflexo é ontologicamente esboço da recusa fundamental da morte. Longe de estar do lado do tempo, “a memória, como o imaginário, ergue-se contra as faces do tempo e assegura ao ser, contra a dissolução do devir, a continuidade da consciência e a possibilidade de regressar, de regredir, para além das necessidades do destino" (DURAND, 1997, p. 403). Frente às "faces do tempo" e à cristalização da "memória", o homem se vê isolado, ilhado, mesmo estando rodeado por uma multidão. Mergulhado em um mundo de imagens e realidades que dão uma configuração à própria vida, ele é sabedor da sua condição existencial: a solidão habita a sua vida. Ou seja, ela é experiência viva que se concretiza não só enquanto recolhimento, mas, acima da tudo, como sentimento intrínseco frente à sensação de isolamento e vazio vivenciado pelo sujeito humano.

Para Octavio Paz, o vocábulo imagem possui múltiplas definições, entre elas um valor psicológico, pois elas são produtos do imaginário. A imagem é toda forma verbal, frase ou conjunto de frases, que o poeta diz e que interligadas entre si compõem o poema. 
Toda imagem, ou cada poema composto de imagens, enquanto "cifra da condição humana", contém um número extraordinário de significados contrários ou díspares. "Toda imagem aproxima ou conjuga realidades opostas, indiferentes ou distanciadas entre si. Isto é, submete à unidade a pluralidade do real" (PAZ, 1991, p. 120).

Os textos literários, plásticos, visuais, imagéticos dos poetas e artistas que abordam as imagens das Cataratas do Iguaçu e Sete Quedas, (imagens das belezas naturais do Paraná) são embasadas em um fazer poético e artístico centrados na força da linguagem e na concretização de um dizer que aponta para imagens visuais, momentos de observação atenta de um eu em sintonia com o mundo circundante.

\section{Cataratas do Iguaçu: a poética das águas}

Um número significativo de poetas do Paraná e do Brasil ao (re) apresentar as imagens poéticas, pictográficas, figurativas, visuais, centram suas obras em um universo poético e imaginário em que configuram espaços de lirismo, elaboração estética e construções de "mundos imaginários possíveis, com obras que apresentam o social, o mítico e as configurações centradas nos campos da imaginação e da memória. Privilegia-se, no presente projeto as imagens das belezas naturais do Paraná, com suas imagens poéticoplásticas, das Cataratas do Iguaçu e Sete Quedas, tão "cantados" e (re)apresentados pelos poetas e artistas.

O poeta Fábio Campana, em Paraíso em Chamas (2013), assim se expressa sobre as Cataratas [do Iguaçu]: 


\title{
CABEZA DE VACA
}

\author{
Dom Alvar Nuñes \\ Cabeza de Vaca \\ não achou ouro, \\ não achou prata, \\ muito menos diamante, \\ achou as Cataratas. \\ E como fazem os turistas \\ deslumbrou-se por um dia \\ e seguiu adiante, \\ deixando detrás de si \\ os estragos típicos \\ do visitante. \\ (CAMPANA, 2013, p. 63)
}

São versos que expressam a visão do eu lírico que reporta ao passado - enquanto espaços da memória - e centra o olhar na questão do deslumbramento da natureza mesmo que seja de um tempo curto, mas que segue adiante deixando as marcas do que seria os "os estragos típicos do visitante". Com o olhar voltado ao explorador Cabeza de Vaca aos turistas contemporâneos, que se não encontram ouro ou prata, se encantam com as belezas naturais das cataratas. 0 explorador espanhol Alvar Nuñez Cabeza de Vaca foi o primeiro homem branco a avistar as Cataratas do Iguaçu, em 1542, quando "se deslocava do litoral de Santa Catarina rumo a Assunção, no Paraguai, cidade recém-fundada por expedições anteriores, quando se deparou com a grandiosidade das quedas d'água." ("Cataratas do Iguaçu”, 2015).

Segundo Maurício Ragagnin Pimentel (2010), a "mesma 'falha geológica' é atribuído um sentido diverso pelo explorador Cabeza de Vaca, e hologramaticamente pela sociedade quinhentista espanhola a que este pertencia. Este, que conta-se ser o primeiro branco a relatar as quedas, lhes atribuiu uma toponímia cristã: Saltos de Santa Maria. Em sua busca pelas riquezas minerais americanas, o explorador acompanha os índios em um caminho às entranhas do 
continente, o Peabiru. Sua intencionalidade apreendia os rios como meios de navegação." (PIMENTEL, 2010. Grifo nosso).

Álvar Núñez Cabeza de Vaca foi o primeiro branco a contemplar as Cataratas do Iguaçu e também a foz [do Iguaçu]:

\begin{abstract}
Mas ao irem rio Iguaçu abaixo, era tão forte a correnteza que as canoas corriam com muita fúria. Logo adiante do ponto onde haviam embarcado o rio dá uns saltos por uns penhascos enormes e a água golpeia a terra com tanta força que de muito longe se ouve o ruído. De modo que foi necessário sair da água, tirar as canoas e conduzi-las por terra até passar aqueles saltos. Assim, à força de braços, as conduziram por mais de meia légua passando grande trabalho. Vencido aquele obstáculo, voltaram a colocar [as canoas] no [rio] Paraná. Quis Deus que a gente que ia por terra com os cavalos e os que iam por água com as canoas chegassem ao mesmo tempo. (CABEZA DE VACA, 2009, p. 125-126).
\end{abstract}

Se o desnível do rio Iguaçu, na observação do explorador foi notoriamente interpretado como "um obstáculo", os apontamentos do explorador direcionam para a observação das terras planas, boas para o cultivo. Já "as áreas silvestres, montanhas e pântanos eram tidos como os símbolos vivos do que merecia ser condenado." Em outros trechos Cabeza de Vaca (1987, p.138) narra os recursos dessa terra que parece ser "a mais fértil do mundo". A natureza era apreciada segundo sua utilidade e a capacidade do homem em dominá-la. (apud PIMENTEL, 2010).

Note-se, no poema "Cabeza de Vaca", de Campana, que ao se criar estruturas, relações, a partir de elementos preexistentes, o poeta mediante a criatividade conecta estruturas mentais, expressas mediante formas e linguagem altamente elaborada, resulta em uma construção poética alicerçada na arte-poesia. Dos golems de palavras, labirintos de imagens, águas, mármores de pedra e cores, sons ou gestos, os poeta-artistas combinam esses materiais com o intuito de "intensificar a experiência e provocar profundas emoções para distinguir certas composições de ações fluentes, distinção que 
hoje em dia é mais necessária que nunca" (RACIONERO, 1995, p. 15-16).

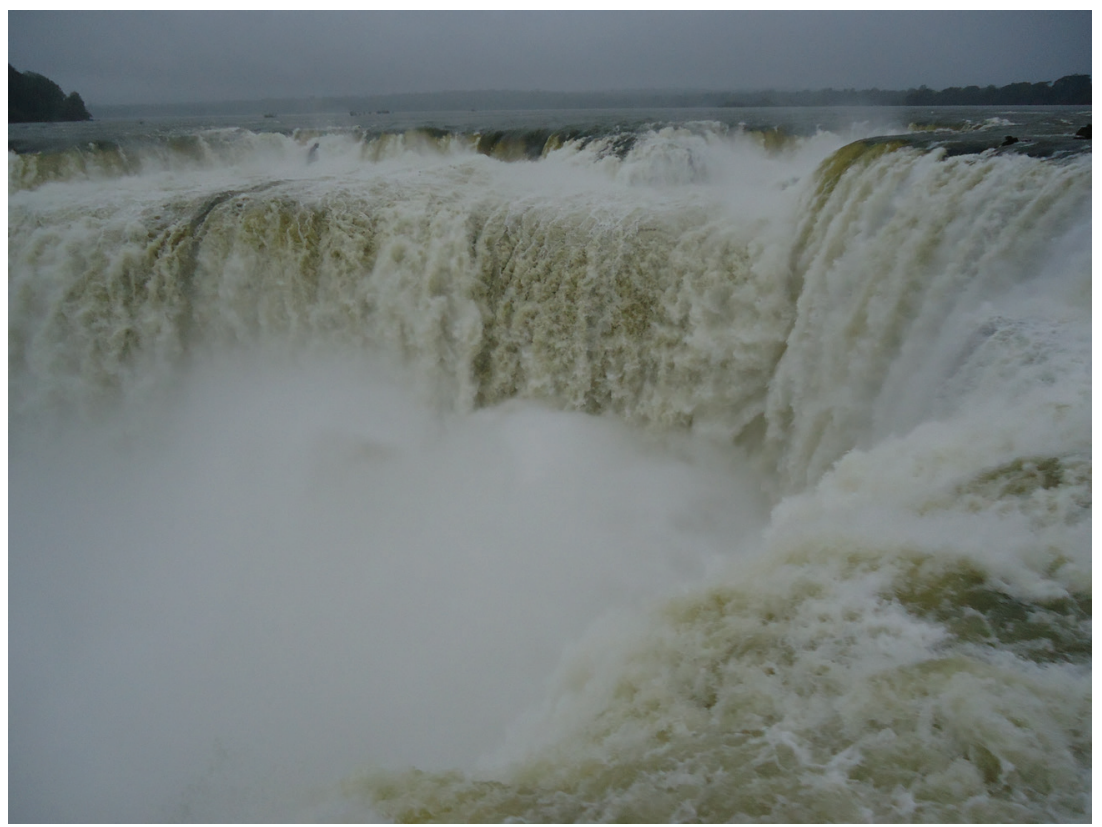

Figura 1: Garganta do Diabo - Cataratas do Iguaçu (lado argentino). Out. 2011.

Fonte: Fotografia de Antonio Donizeti da Cruz

A pintura intitulada "Cataratas do Iguaçu" (1920), do artista Frederico Lange de Morretes, mostra a vigor e a beleza de uma das mais belas paisagens da natureza: 


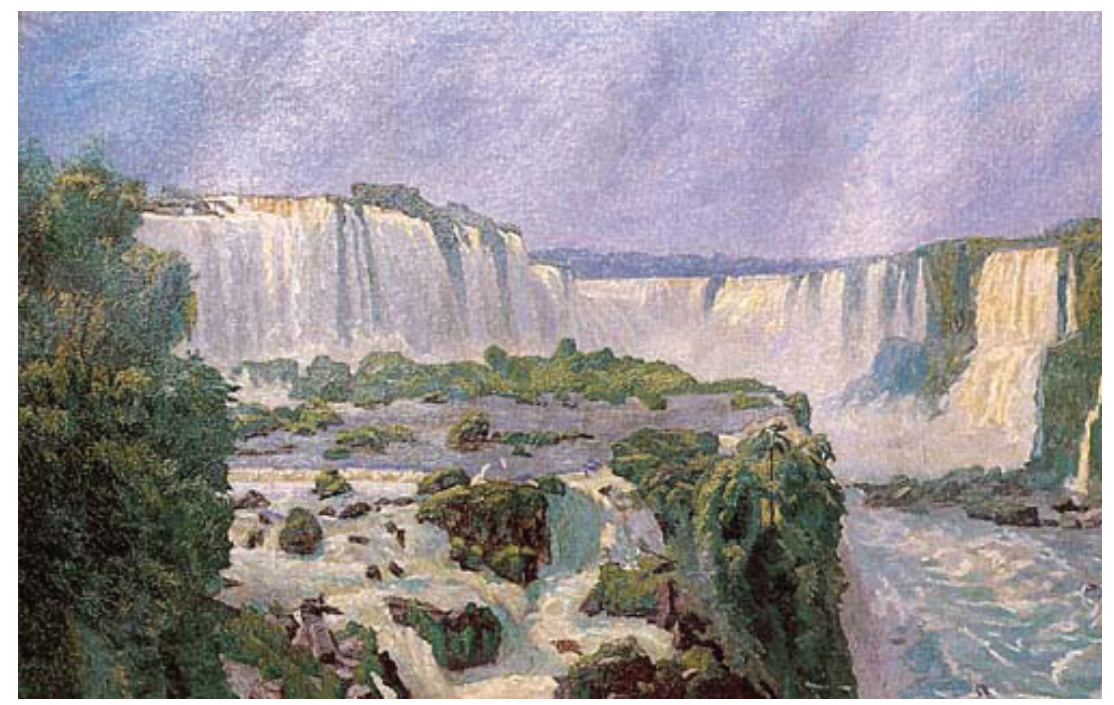

Figura 2: LANGE DE MORRETES, Frederico. - Cataratas do Iguaçu, 1920. Óleo sobre tela. 143 x 224 cm. Coleção Clube Curitibano.

Fonte: PINTORES da Paisagem Paranaense, 2005, p. 163.

A harmonia e beleza da tela apresenta o olhar de encantamento pelo quadro natural, visto pelo olhar do artista Frederico Lange (1892 - 1954), mais conhecido como Friz Lange de Morretes, foi pintor, desenhista, gravador e professor paranaense e um dos idealizadores do paranismo. Nota-se, na pintura, a vasta unidade da água, uma vez que na acepção de Bachelard, em A água e os sonhos: ensaio sobre a imaginação da matéria, "o riacho, o rio, a cascata têm, pois, um falar que os homens compreendem naturalmente. Como diz Wordsworth, "uma música da humanidade" (1989a, p. 201). Nesse sentido, em toda a atividade poética (plástica), há uma espécie de reflexo condicionado, quer se trate das raízes que reúnem impressões visuais, auditivas e vocais, justamente pelo fato de a "água tem também vozes indiretas". A natureza repercute ecos ontológicos. Os seres respondem-se imitando vozes elementares. De todos os elementos, a água é o mais "fiel 
espelho das vozes" [Tristan Tzara]." (BACHELARD, 1989a, p. 199).

O turbilhão das águas também é registrado na pintura de Antonio Diogo da Silva Parreiras (1860-1937), intitulado "Cataratas do Iguaçu", de 1920, com suas cores e pinceladas que iluminam e dão vida à tela, em que se percebe um índio contemplando as cataratas com suas águas de denso volume e o canto das águas:

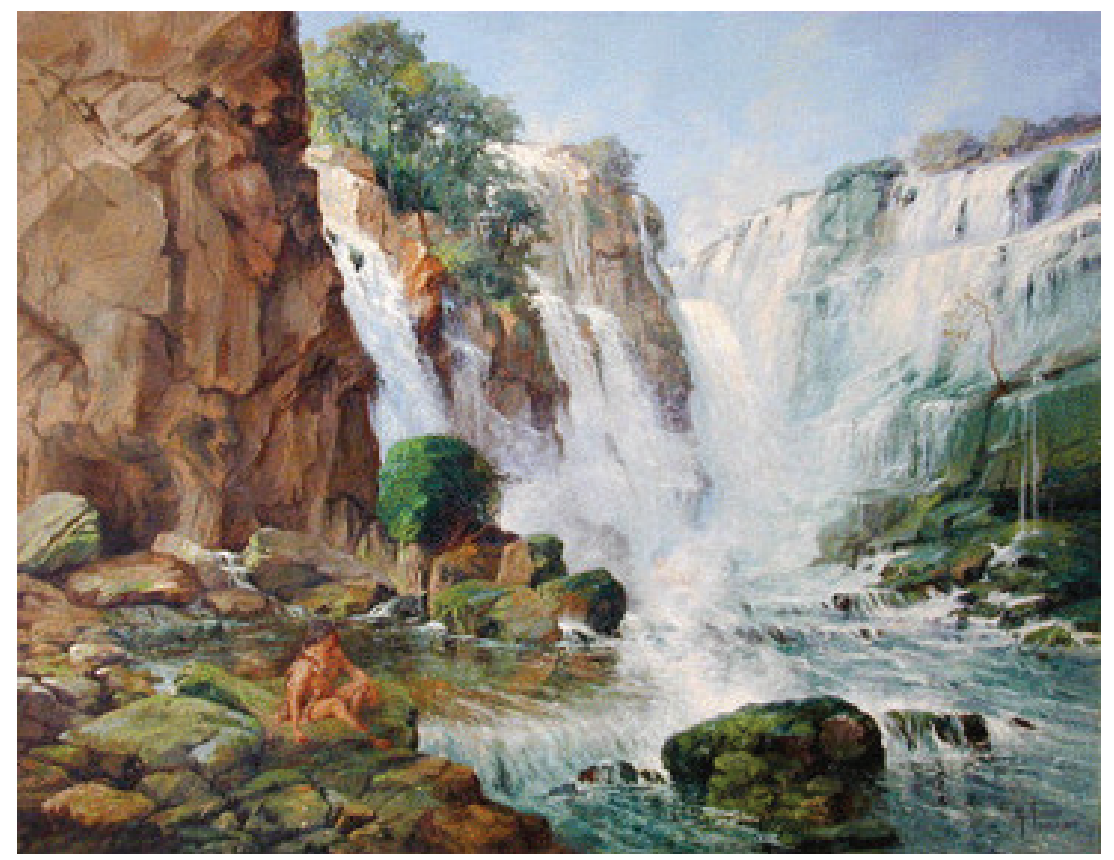

Figura 3: PARREIRAS, Antonio (1860-1937). - Cataratas do Iguaçu, 1920. Óleo sobre tela. 200 x $250 \mathrm{~cm}$. Coleção Palácio Iguaçu.

Fonte: PINTORES da Paisagem Paranaense, 2005, p. 164.

As "Vozes das águas" são apresentas pela poeta Helena Kolody, no texto de densa significação lírica ao descrever as Cataratas do Iguaçu, marcada pela beleza natural e grandeza do espetáculo no "imenso palco" da natureza: 


\section{CATARATAS DO IGUAÇU}

Num profundo clamor,

Salta no abismo o turbilhão das águas.

Referve na garganta, em convulsões, e espuma, Ergue-se em renda e névoa, que o sol irisa,

No imenso palco escarpado, Esgarçam-se líquidos tules, Há esguias águas dançantes, Nevoeiros de arco-íris.

No abismo do tempo imemorável, Reboa, soturna, a voz das cataratas. (KOLODY, Helena. 1999, p. 160)

As imagens das águas em turbilhão geram contrastes com as formas de renda e névoa irisada pelos raios do sol. São movimentos dançantes das águas e do "abismo do tempo imemorável", em que se privilegia uma memória do mundo e do ressoar das vozes das águas. 


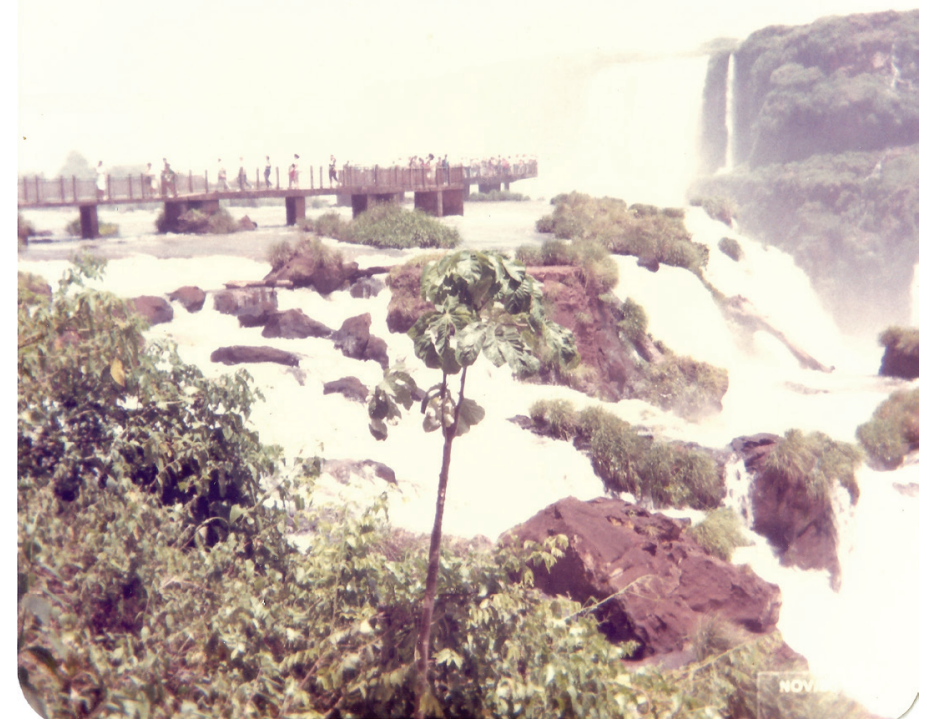

Figura 4: Cataratas do Iguaçu - Nov. 1986.

Fonte: Fotografia de Antonio Donizeti da Cruz.

0 poeta Mario Quintana também tece seu canto de amor às "Cataratas do Iguaçu", no poema que apresenta as imagens dos rios como caminhos mais antigos do mundo, com suas formas e cores, "serpenteiam" os espaços geográficos e não há como limitá-los e sequer parar o curso das águas. 0 questionamento movimenta o poema na indagação do sujeito lírico:

\section{CATARATAS DO IGUAÇU}

Os rios são caminhos

mais antigos

que a redondeza da terra.

Eles descem horizontes

seguem sozinhos no ar. 
E a bela asa em pleno voo, entre o partir e o chegar, sem se importar com fronteiras.

Mas como se há de parar?

(QUINTANA, Mario, 2015)

Os poemas de Mario Quintana e Helena Kolody atestam que não é possível compreender a arte de um determinado período histórico, conforme diz Racionero (1995), sem entender a visão que o homem tem de si mesmo e de sua relação com o mundo no momento em questão. 0 homem deseja distintas coisas em lugares e momentos diferentes. Ele se vê a si mesmo - no universo - de distintas maneiras em momentos e lugares diferentes. Ele se reflete em sua arte. A intuição imaginativa dos problemas que se valorizam em cada época é uma das funções da arte, a qual, ao funcionar por abandono poético à associação de ideias, aos vislumbres, permite captar e expressar o incipiente, ainda formalizar o recém-aceitado. Em nível instrumental, no referente ao material e às ferramentas necessárias para penetrar em um novo campo, é a ciência que vai adiante, de modo que, quando são inventados instrumentos de observação mais precisos, permite-se observar o que as gerações precedentes tiveram que descobrir mediante a imaginação. A olhar atento e valorização da Natureza sempre foram pontos centrais das reflexões e do ofício dos poetas e artistas ao evocar imagens poéticas que mediante a imaginação as combinam e valorizam tais imagens alicerçando-as na força expressiva e na potência de uma poética capaz de dar sentido à vida. Ao buscar a essência da linguagem, os artistas realizam o poder mágico através das palavras poéticas e das imagens enquanto mediação, comunicação e exercício de construção de sentidos, uma vez que elas são manifestações dos entes e seres.

Nas palavras de Javier González (1990), é sempre mediante o universo poético, que o poeta apoia-se nos aspectos lúdicos, rítmicos e imaginários da linguagem, uma vez que a função poética funciona como um vetor constitutivo da natureza humana. É pela palavra que 
o homem se coloca no plano expressivo superior a não significação da ordem natural, pois ela, enquanto núcleo de dispersão e convergência, é capaz de nomear o mundo (GONZÁLEZ, 1990, p. 152-153). Nesse sentido, o trabalho do poeta, artista, se estabelece frente aos meios de fixação e dispersão de sentido, ou seja, como uma construção modular e jogo de palavras que têm por finalidade projetar um grande número de significações, em que o escritor descobre e constrói o mundo utilizando a palavra enquanto instrumento - como bem afirma González - "capaz de conter a surpreendente variedade do real", isto é, ele sabe que o uso da linguagem abre múltiplos espaços de "comunicação e de nominação dos objetos", com bem afirma Gonzáles (1990, p. 156-157).

\section{Sete Quedas: lembrar para não esquecer}

Uma das tarefas primordiais do poeta está na busca de uma elaboração que possibilita representar as coisas e o mundo por das formas simbólicas, uma vez que é mediante a imaginação que se constrói uma poética alicerçada um mundo de sentidos que se interligam à "memória ontogenética", isto é, todo o (re)criar "remete à criação artística e à fruição estética da obra de arte" (MANCIA, 1990, p. 155-159. Grifo do autor). Sendo assim, Mancia observa que ao criar, o artista percorre "todas as etapas do processo que o levou a construir o seu mundo interno", no sentido de recriar objetos que correspondem ao "seu mundo 'ideal' ou 'sublime', aos quais confere uma nova disposição espaço-temporal” (p. 167. Grifo do autor).

Recordar é elemento inerente ao fazer poético e pictórico enquanto registros e arquivos centrados no poder das rememorações e a maneira como o poeta e artistas organizarem os textos, direcionando-os ao tempo e às configurações de imagens que trazem certa valorização da natureza e também os registros de nostalgia e sentimento melancólico em relação a não preservação da natureza, em que o espetáculo do mundo e as paisagens naturais 
precisam ser (re)apresentados de forma a apontar para o esforço de valorização e de uma atenção cada vez maior, Como diz o filósofo Gaston Bachelard, o sonhador inflamado conjuga o que vê ao já visto, ou seja, conhece perfeitamente a associação entre imaginação e memória (1989b, p. 19).

Assim, fundamentando-se em Bachelard, pode-se dizer que os poetas e os artistas, em geral, realizam um fazer poético organizado no mundo das imagens e na rememoração das coisas mais singelas, que despertam para as imagens mais ternas e para as belezas naturais, que semelhante às obras de arte existem para ser contempladas, decodificadas, dialogadas, testemunhadas e perpetuada. Nesse sentido, os poemas, imagens, pinturas e fotografias das Belezas naturais do Paraná, ficam marcados no tempo e a na memória e são forças mediadoras e potências capazes de interligar os fatos, as pessoas e suas ações e as coisas do mundo para que não se perca a memória e para uma maior valorização da natureza, como a projeção da pintura do artista Alfredo Andersen (1860-1935), intitulada Sete Quedas, pintada em 1904 em que visualiza-se o conjunto dos Saltos das Sete Quedas:

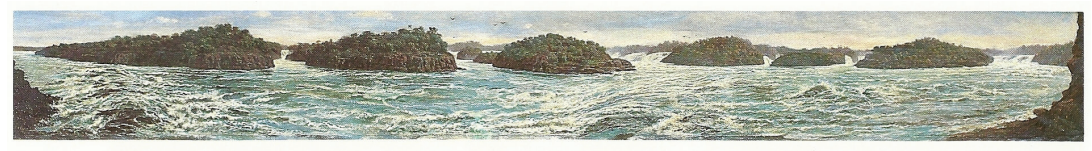

Figura 5: ANDERSEN, Alfredo (1860-1936). - Sete Quedas. Óleo sobre tela. 41 x $322 \mathrm{~cm}$. Coleção Palácio Iguaçu. Coleção Orlando Villela Bittencourt.

Fonte: PINTORES da Paisagem Paranaense, 2505, p. 159.

O poema "Adeus a Sete Quedas", de Carlos Drummond de Andrade, publicado no Jornal do Brasil, de nove de setembro de 1982, é um réquiem às Sete Quedas, e traz duas epígrafes: "Sete damas por mim passaram, / E todas sete me beijaram." de Alphonsus de Guimaraens, e "Aqui outrora retumbaram hinos." de Raimundo Correia. Note-se a forte crítica social do poeta Drummond: 


\section{Adeus a Sete Quedas}

Sete damas por mim passaram,

E todas sete me beijaram.

Alphonsus de Guimaraens

Aqui outrora retumbaram hinos.

Raimundo Correia

Sete quedas por mim passaram, e todas sete se esvaíram.

Cessa o estrondo das cachoeiras, e com ele a memória dos índios, pulverizada, já não desperta o mínimo arrepio.

Aos mortos espanhóis, aos mortos bandeirantes, aos apagados fogos

de Ciudad Real de Guaira vão juntar-se

os sete fantasmas das águas assassinadas

por mão do homem, dono do planeta.

Aqui outrora retumbaram vozes

da natureza imaginosa, fértil

em teatrais encenações de sonhos

aos homens ofertadas sem contrato.

Uma beleza-em-si, fantástico desenho

corporizado em cachões e bulcões de aéreo contorno

mostrava-se, despia-se, doava-se

em livre coito à humana vista extasiada.

Toda a arquitetura, toda a engenharia

de remotos egípcios e assírios

em vão ousaria criar tal monumento.

E desfaz-se

por ingrata intervenção de tecnocratas.

Aqui sete visões, sete esculturas

de líquido perfil

dissolvem-se entre cálculos computadorizados

de um país que vai deixando de ser humano

para tornar-se empresa gélida, mais nada. 
Faz-se do movimento uma represa, da agitação faz-se um silêncio empresarial, de hidrelétrico projeto. Vamos oferecer todo o conforto que luz e força tarifadas geram à custa de outro bem que não tem preço nem resgate, empobrecendo a vida na feroz ilusão de enriquecê-la.

Sete boiadas de água, sete touros brancos, de bilhões de touros brancos integrados, afundam-se em lagoa, e no vazio que forma alguma ocupará, que resta senão da natureza a dor sem gesto, a calada censura e a maldição que o tempo irá trazendo?

Vinde povos estranhos, vinde irmãos brasileiros de todos os semblantes, vinde ver e guardar não mais a obra de arte natural hoje cartão-postal a cores, melancólico, mas seu espectro ainda rorejante de irisadas pérolas de espuma e raiva, passando, circunvoando, entre pontes pênseis destruídas e o inútil pranto das coisas, sem acordar nenhum remorso, nenhuma culpa ardente e confessada. ("Assumimos a responsabilidade! Estamos construindo o Brasil grande!") E patati patati patatá...

Sete quedas por nós passaram, e não soubemos, ah, não soubemos amá-las, e todas sete foram mortas, e todas sete somem no ar, sete fantasmas, sete crimes dos vivos golpeando a vida que nunca mais renascerá.

(ANDRADE, Carlos Drummond de. Jornal do Brasil, Caderno B, 09 set. 1982. In: Drummond: 100 anos. 2015) 
No poema, Carlos Drummond de Andrade manifesta sua inconformidade em relação à destruição do Salto de Sete Quedas - enquanto patrimônio natural do Brasil e da humanidade - por causa da construção da hidrelétrica de Itaipu. 0 eu lírico relembra os mortos da Conquista e dos Bandeirantes e conclama se juntarem a eles "os sete fantasmas das águas assassinadas / por mão do homem, dono do planeta" e tece um panorama do quadro real da história e alude à arquitetura engenhosa da natureza e, por outro lado, aponta para a "destruição" das Sete Quedas pela intervenção de tecnocratas. E conclama a todos para ver pela última vez os Saltos das Sete Quedas e guardá-la para sempre na memória e em cartões postais, mas sem remorso, uma vez que todos "estamos construindo o Brasil grande!". E na última estrofe a triste constatação de que elas passaram, foram destruídas pela falta de amor. Crime, em número de sete, que golpeia a vida que jamais renascerá, tal como afirma o sujeito da enunciação. 


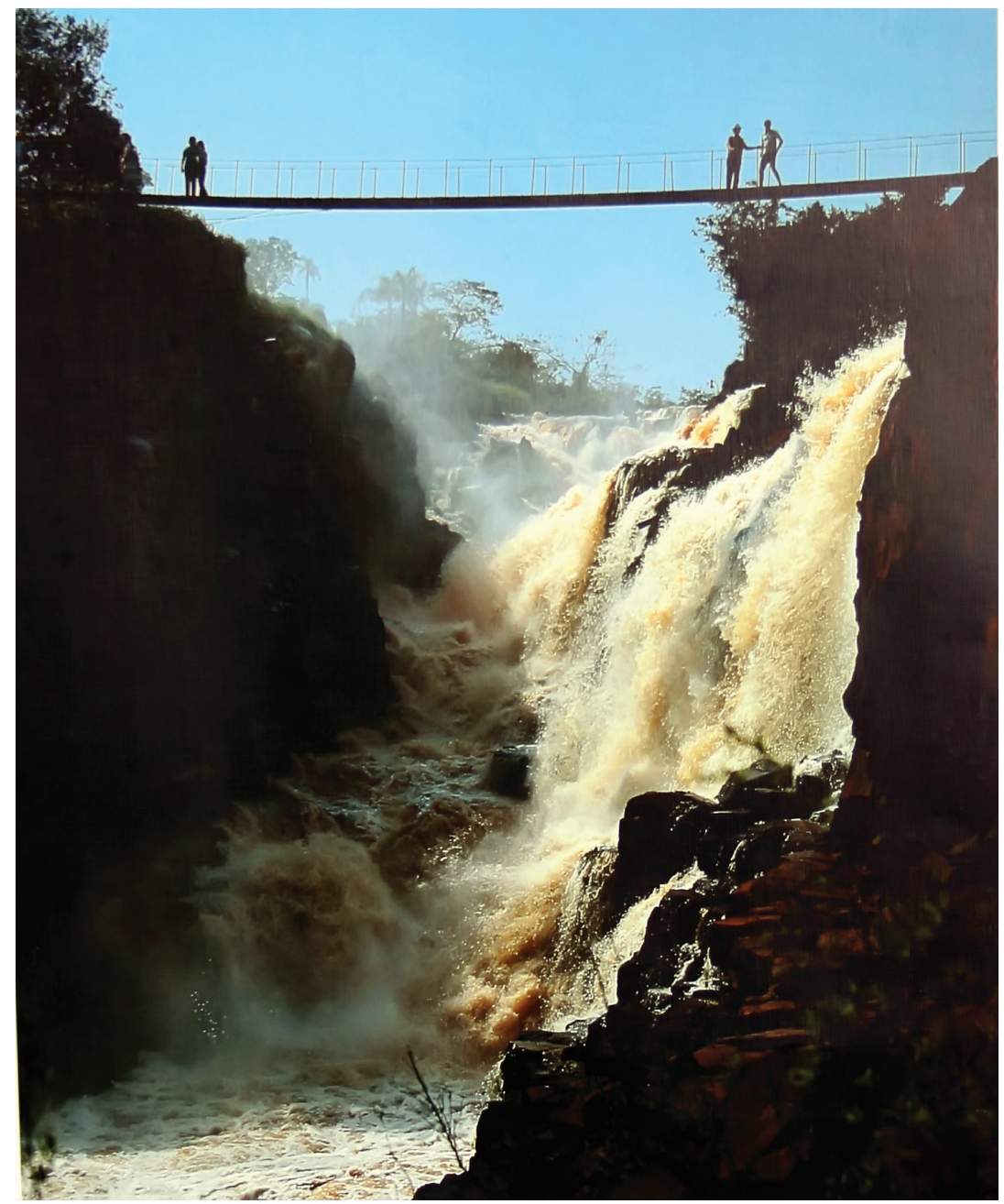

Figura 6: Sete Quedas

Fonte: Foto (Crédito e Cortesia) - Arquivo do Jornal $O$ Presente. Sete Quedas. Marechal Cândido Rondon - PR

O Salto de Sete Quedas também denominado Salto Guaíra (Saltos del Guairá, em castelhano) foi a maior cachoeira do mundo em volume de água, até o seu desaparecimento com a formação do lago da Usina hidrelétrica de Itaipu. Sete Quedas, apesar do nome, eram formadas por dezenove saltos principais, sendo agrupadas em sete grupos de quedas. 
Em relação à Memória, o poeta e crítico Octavio Paz afirma que os poetas têm sido a memória de seus povos, pois "cada poeta é uma pulsão no rio da tradição, um momento da linguagem. Às vezes os poetas negam sua tradição mas só para inventar outra" (1993, p. 109). A invenção lírica se projeta do presente para o futuro. 0 poeta é ciente de sua tarefa: ser elo da cadeia, uma ponte entre o ontem e 0 amanhã. Entretanto, no findar do século XX, ele "descobre que essa ponte está suspensa entre dois abismos: o do passado que se afasta e o do futuro que se arrebenta. 0 poeta se sente perdido no tempo" (PAZ, 1993, p. 108-109). Nesse sentido, ao recriar sua experiência, leva avante um passado que é um futuro. 0 tempo possui uma direção, um sentido, ou seja, "ele deixa de ser medida abstrata e retorna ao que é: concretude e dotado de direção. 0 tempo é um constante transcender" (PAZ, 1982, p. 69).

A função essencial do tempo na estruturação da imagem do mundo reside, conforme Octavio Paz, no fato de que o homem, dotado de uma direção e apontando para um fim, faz parte de um processo intencional (1993, p. 97). Os atos e as palavras dos homens são feitos de tempo. Assim, a cronologia está fundamentada na própria crítica. Já a poesia é tempo revelado, isto é, o enigma do mundo que se transforma em "enigmática transparência". 0 poeta diz o que diz o tempo, até quando o contradiz, pois ele é capaz de nomear o transcorrer, e ainda, "torna palavra a sucessão" (PAZ, 1993, p. 98).

Do tempo revelado, das lembranças e esquecimento de que fazem parte a MEMÓRIA, o poeta é o elo que mediante o processo intencional faz com que as palavras, as imagens poéticas, bem como todas as formas de (re)apresentações da vida e da natureza se convertam em uma grande construção individual e coletiva de preservação da memória:

No "canto" do poeta, os flashes que captam momentos únicos e também nas pinceladas dos artistas, o registro de um tempo marcado pelas lembranças e tecidos nos tênues fios da memória, tal como as passagens do poema "Réquiem para as Sete Quedas", do poeta, ensaísta e escritor João Manuel Simões: 


\section{Réquiem para as Sete Quedas}

Sete quedas, Sete Quedas

(eram sete ou eram mais?)

sete templos liquefeitos, capelas e catedrais, sete cascatas de luz, sete líquidos vitrais, sete sonatas etéreas, sete orfeões, sete corais, sete cantos camonianos, sete poemas minerais, (os versos são alva espuma, as rimas puros cristais) sete quedas, sete quedas que não se levantam mais.

Sete dores, sete mortes, sete afiados punhais, sete gemidos de angústia, [...]

Sete véus, sete grinaldas, sete sonhos nupciais que as sete noivas sonhavam, (sonhos tecidos com fios argênteos de sol e luar). [...] Sete Quedas, Sete Quedas, em tempo de nunca mais, sete mortalhas escondem vossos restos imortais de noivas que se tornaram dos altos deuses vestais. [...] Quando voltarão à vida as sete noivas fatais? Pergunto à brisa que canta na terra dos pinheirais [...] Sete Quedas, Sete Quedas, em vão as invoco, em vão: elas jazem soterradas 
na mais profunda solidão.

[...]

(Sete Quedas, Sete Quedas, noite no meu coração!)

Sete Quedas, Sete Quedas, (eram sete ou eram mais?) Eram sete, sete apenas mas na saudade são mais. (SIMÕES, João Manuel, 1982, p. 9-21)

Os versos do poema de João Manuel Simões, além da crítica social a que se refere o sujeito da enunciação, registra a preocupação do eu lírico ao constatar o desaparecimento das Sete Quedas, cujo canto transforma-se em réquiem, tendo em vista a perda da beleza natural que o Estado do Paraná, o Brasil e o mundo perderam ao dar lugar à construção da hidrelétrica de Itaipu. No texto mostra a força da memória que tem o poder de ativar ou reter as coisas e apontando para a necessidade de se preservar a natureza. Recordar as Sete Quedas é um fator imprescindível que movimenta as aspirações e sentimentos do sujeito poético, pois no momento da recordação o eu lírico rememora, com saudade e erguendo sua voz lembrar a todos da atenção que é preciso ter para com a valorização da natureza. Assim, o texto é uma alerta para que não ocorra destruição das belezas naturais.

As imagens das Sete Quedas e das Cataratas do Iguaçu fornecem múltiplas categorias de percepção de beleza que ficou desaparecida no espaço geográfico e na perda da imagem repleta de beleza e encantamento das manifestações dos Saltos das Sete Quedas, imagens instauram lembrança e um sentimento de tristeza em saber ficaram submergidos em prol do "progresso". Há toda uma valorização das imagens que ficam marcadas nas lembranças das paisagens naturais das Sete Quedas, em que as operacionalizações dos poetas, artistas, que as relembram apontam para as reconstruções de registros e acontecimentos passados. Os olhares e os textos dos escritores e artistas que se voltam para as 
rememorações vividas e registradas que acentuam o poder das imagens e seu poder de simbolização.

\section{REFERÊNCIAS BIBLIOGRÁFICAS}

ANDRADE, Carlos Drummond de. "Adeus a Sete Quedas". Jornal do Brasil, Caderno B, 09 set. 1982. In: Drummond: 100 anos. Disponível em: http://www.algumapoesia.com.br/ drummond/drummond30.htm Acesso em 9 mar 2015.

BACHELARD, Gaston. A água e os sonhos: ensaios sobre a imaginação da matéria.Trad. Antonio de Padua Danesi. São Paulo: Martins fontes, 1989a.

BACHELARD, Gaston. A chama de uma vela. Rio de Janeiro: Bertrand Brasil, 1989b.

BACHELARD, Gaston. A poética do espaço. São Paulo: Martins Fontes, 1993.

CABEZA DE VACA, Álvar Núñez. Naufrágios \& Comentários. Trad. de Jurandir Soares dos Santos. Porto Alegre: L\&PM, 2009 (1. ed. em espanhol 1542).

CATARATAS do Iguaçu - Uma das sete maravilhas da natureza. Disponível em: http://www.fozdoiguacudestinodomundo. com.br/atrativos/cataratas-do-iguacu Acesso em 09 mar. 2015.

CAMPANA, Fábio. Paraíso em chama. Curitiba: Travessa dos editores, 2013. 
DAVALLON, Jean. A imagem, uma arte da memória? In: Papel da memória / Pierre Achard. [et al.]; tradução e introdução de José Horta Nunes. Campinas, SP: Pontes, 1999.

DURAND, Gilbert. A imaginação simbólica. Lisboa: Edições 70, 1995.

DURAND, Gilbert. Campos do imaginário. Textos reunidos por Danièle Chauvin. Trad. Maria João Batalha Reis. Lisboa: Instituto Piaget, 2003.

DURAND, Gilbert. As estruturas antropológicas do imaginário: introdução à arquetipologia geral. Trad. Hélder Godinho. São Paulo: Martins Fontes, 1997 (Ensino Superior).

GONZALES, Javier. El cuerpo y la letra: la cosmología poética de Octavio Paz. México - Madrid - Buenos Aires: Fondo de Cultura Económica, 1990.

KOLODY, Helena. "Cataratas do Iguaçu”. In: Viagem no espelho. 5. ed. Curitiba: Editora da UFPR, 1999.

MANCIA, Mauro. No olhar de Narciso: ensaios sobre a memória, o afecto e a criatividade. Lisboa: Escher, 1990.

PAPEL da memória / Pierre Achard. [et al.]; tradução e introdução de José Horta Nunes. Campinas, SP: Pontes, 1999.

PAZ, Octavio. $O$ arco e a lira. Trad. Olga Savary. Rio de Janeiro: Nova Fronteira, 1982 (Coleção Logos).

PAZ, Octavio. A outra voz. São Paulo. Siciliano, 1993. 
PAZ, Octavio. Convergências: ensaios sobre arte e literatura. Trad. Moacir Werneck de Castro. Rio de Janeiro: Rocco, 1991.

PIMENTEL, Maurício Ragagnin. Cataratas do Iguaçu: experiências e registros de uma paisagem turística. Porto Alegre: Dissertação (Mestrado) - Universidade Federal do Rio Grande do Sul. Instituto de Geociências. Programa de PósGraduação em Geografia, Porto Alegre, RS, UFRGS/PPGEA, 2010.

PINTORES da Paisagem Paranaense. Edição fac similar. Curitiba: Secretaria de Estado da Cultura: Solar do Rosário, 2005.

QUINTANA, Mario. “Cataratas do Iguaçu”. Disponível em: http://prosapoesiaecia.xpg.uol.com.br/quintanamestres. htm Acesso em 09 mar. 2015).

SIMÕES, João Manuel. Réquiem para Sete Quedas. Curitiba: Lítero-Técnica, 1982. 



\title{
ESCREVENDO-SE MULHER: UM DIÁLOGO ENTRE A CRÍTICA FEMINISTA E A LÍRICA DE MARIA TERESA HORTA
}

\section{WRITING ONESELF AS A WOMAN: A DIALOGUE BETWEEN FEMINIST CRITICISM AND THE POETRY BY MARIA TERESA HORTA}

\author{
Natália Salomé de SOUZA ${ }^{1}$ \\ Vinícius Carvalho PEREIRA ${ }^{2}$
}

\begin{abstract}
Resumo: Maria Teresa Horta, poetisa portuguesa contemporânea, faz de sua lira um exercício do que a crítica feminista convencionou chamar de écriture féminine, ou escrita feminina. Suas escolhas estéticas são, pois, escolhas também políticas, em que a poesia se constrói a partir do corpo numa busca do sentido do ser mulher. Perquirição identitária no seio da linguagem, os poemas da autora se constituem como experiências eróticas de autoconhecimento, em que a mulher possa se entender como positividade, e não como negação do masculino. No presente artigo, colocam-se em diálogo teorias da crítica feminista e alguns textos da obra de Maria Teresa Horta, a fim de melhor compreender como
\end{abstract}

\footnotetext{
${ }^{1}$ Graduada em Letras (UFMT), Mestranda do Programa de Pós-Graduação em Estudos de Linguagem (UFMT) - natsalome@gmail.com

2 Doutor em Ciência da Literatura (UFRJ) e professor do Departamento de Letras e do Programa de Pós-Graduação em Estudos de Linguagem (UFMT) viniciuscarpe@gmail.com
} 
a escrita feminina da autora (e por que não da eu-líricA?) pode ser metonímia de uma busca de todas as mulheres por um espaço de diferença sexual - inalienável do gozo, da letra, do poema.

Palavras-chave: Maria Teresa Horta. Crítica feminista. Écriture féminine.

\begin{abstract}
Maria Teresa Horta, a contemporary Portuguese poet, exercises in her poetry what feminist criticism calls écriture féminine, or women's writing. Therefore, her aesthetic choices are also political, whereby poetry comes up from a quest for what it means to be a woman. In a search for identity within the realm of language, the poems by this writer are erotic experiences of self-knowledge, where the woman can be understood as something positive, not as a negation of masculinity. In this paper we propose a dialogue between theories from feminist criticism and some texts by Maria Teresa Horta, to better understand how the author's feminine writing (and why not the writing of a feminine lyrical-I?) can be a metonymy of all women's quest for a space of sexual difference - inextricable from joy, letter and poetry.
\end{abstract}

Keywords: Maria Teresa Horta. Feminist criticism. Écriture féminine.

\title{
Introdução
}

Mulher, mulher, mulher. Talvez nos dissessem que devêssemos usar um dicionário de sinônimos para evitar a repetição desnecessária. Necessária para nós. Mas se nos deixamos dominar pela lógica falogocêntrica, mantemo-nos na busca pelo nome: recusamo-nos à busca dos falsos sinônimos. Ser mulher não cabe no nome, não é captável pelos nomes. É inominável, é fluido e circular. Retorna a si mesma, assim como a escrita, porque se toca, leve, intensa, repetidamente. Se reescreve! Se inscreve: no corpo.

É através da lógica da não presença que a mulher se mantém presa, mas e se usar essa mesma lógica para se libertar? E se for no interdito - para os ouvidos e olhos masculinos - que sua música 
se faz? Parler femme ${ }^{3} .$. falar: mulher. São tantas e são diversas. Diversas em si, diversas deles - e não como retrato dele ou dela, mas como celebração da diferença que não se compara. Não vemos a diferença pelo negativo: não é pela falta do falo, é na positividade da fala - multiplicidade que a mulher encarna e de que é a diferença. "Porque o que eu quero, de fato, não é criar uma teoria da mulher, mas assegurar um lugar para o feminino dentro da diferença sexual." (IRIGARAY, 1985, p. 159).

Nesse contexto, na dilemática empreitada de um artigo a quatro mãos, em que uma mulher e um homem se põem a escrever, na fluidez polifônica desse discurso acadêmico (mas também poético), pomonos a analisar, sob a ótica da crítica feminista, a produção poética de Maria Teresa Horta. Homem e mulher a falar de mulher, Academia e poesia a falar de literatura: a crítica feminista como exercício de metalinguagem política. Neste artigo, exercitamos, pois, um diálogo da diferença, em que uma escrita feminina, que fala pela pele, pelos poros, pelos lábios da primeira autora, é acolhida, hibridizada mas nunca assimilada - pela voz de seu coautor masculino, a fim de melhor compreender a écriture feminine de Maria Teresa Horta.

A écriture feminine, como nos diz Cixous (2007) é aquela que parte do corpo, mas de um corpo que se conhece e se reclama. Não é o corpo que vem sendo representado ao longo dos séculos, que é milimetricamente detalhado, observado e definido, e sim o corpo que vem ganhando espaços no ser mulher. No corpo que reconhece em si o próprio gozo e a própria dor. Na escrita feminina, a mulher se insere na linguagem e a transforma para que esta possa ser verdadeiramente sua. Não é mais o padrão, a forma, a regularidade masculina que está em vigor, mas o corpo da mulher, fluido como sua fala, intenso tanto quanto seu gozo, que encontra um fim em si próprio, o qual está inscrito nessa escrita. A mulher se escreve e inscreve dando forma a si própria para mostrar que está presente, e que dessa forma se marcará na história, na sociedade.

${ }^{3}$ Ao longo artigo, traduz-se essa locução cunhada por Irigaray (1985) como "falar (como) mulher". 
Sendo, pois, essencialmente poética essa escrita feminina, colocamos em diálogo neste artigo as produções líricas de Maria Teresa Horta, poetisa portuguesa contemporânea, e algumas teorias da crítica literária feminista, que entendem o ato da escrita poética como escrita também do ser mulher. Assim, discutimos aqui como se dá na superfície do corpo a escrita feminina que reclama para si a materialidade do procedimento poético: corpo do texto e corpo da mulher imbricam-se num jogo erótico, em que o gozo devém lírico e a mulher se funda no real e no simbólico.

Tal pesquisa se justifica sob dois vieses complementares: o acadêmico-estético e o sociopolítico. Por um lado, a análise da poesia de Maria Teresa Horta à luz de teorias feministas preenche uma série de lacunas exegéticas nos estudos de literatura portuguesa contemporânea, lançando nova luz sobre uma autora de vasta produção, ainda que duplamente marginalizada pelo cânone - na condição de mulher que escreve sobre a experiência de ser mulher. Por outro lado, o artigo que aqui se delineia é ação política ao ampliar a noção de pós-colonialismo, fazendo do estudo de poesia uma práxis decolonizadora, que permite ao oprimido dizer(-se) (SPIVAK, 1988).

A esse respeito, somem-se alguns dados da biografia da autora cuja obra ora se analisa. Maria Teresa Horta combateu o silêncio da ditadura militar em Portugal ao dar-se voz através de sua poesia erótica, que faz do corpo da mulher instrumento de libertação de si. Repreendida, investigada, julgada e agredida não apenas pelo poder ditatorial de Marcelo Caetano, mas também pelos membros da sociedade patriarcal em que se inseria, a poetisa foi surrada na rua quando da publicação do livro Minha Senhora de Mim (HORTA, 1971). Na publicação de Novas Cartas Portuguesas (BARRENO, COSTA, HORTA, 1974), foi levada a julgamento junto a Maria Isabel Barreno e Maria Velho da Costa, coautoras da obra, por incitarem a emancipação da mulher. No corpo, as chagas da luta que se transplantam como violência e sublevação em sua écriture féminine.

De relevância para a academia enquanto extrapolação do 
cânone e para a afirmação política da mulher, o estudo da poesia de Maria Teresa Horta se justifica também na imanência do texto da autora. Extremamente lírica, sua poesia põe em questão o que é escrever e como este ato confunde-se com o escrever-se. Na página ou na pele - escrivaninha do corpo em que a poesia feminista se dá -, é essa condição da escrita feminina como autoconhecimento e emancipação pelo gozo que o presente artigo visa analisar.

\section{Escrevendo-se mulher pelo corpo}

Encontrar o lugar do feminino dentro da diferença sexual é um grande passo para mudanças da percepção do local da mulher na cultura, na sociedade e na economia. Inseri-la nos espaços através de uma perspectiva que não seja da similitude é, pelo menos, ousado. A similitude levaria a mulher a uma comparação direta com o homem, ou seja, procuraria moldá-la de acordo com as características que a assemelham e a afastam da figura masculina. Dentro dessa perspectiva, existe uma relação hierárquica que prevê que o homem é o padrão, a norma; por isso, diferir dele equivalia a ser-lhe inferior, segundo a lógica do patriarcado.

Tendo seus corpos aprisionados nessa ideologia em que a centralidade está na imagem do falo, as mulheres foram representadas ao longo do tempo de diversas formas que oprimiam sua própria chance de imanência - e talvez de essência -, problema que cabe também aos estudos literários investigar e denunciar. A escrita, como sinal da materialidade, do deixar marcas no mundo, tradicionalmente captou o que a mulher não era e, a partir dessa política da negatividade, não permitiu que a mulher entendesse/ sentisse suas próprias potencialidades.

Assim, as poucas mulheres a quem foi dado o direito de escrever convencionalmente tiveram de fazê-lo dentro de uma linguagem que não era a sua, de um dispositivo discursivo que não as integrava, que não as via e onde elas não cabiam. A mulher só pôde escrever dentro do falogocentrismo (DERRIDA, 1981); dominada pela lei do 
falo - do Pai, e não da Mãe - e pela lei do logos ocidental, ela se emaranhou (ou foi emaranhada) dentro de uma teia cada vez mais fechada onde se tornou uma sombra do que poderia vir a ser.

Desse modo, passou a escrever, mas continuou a se representar (e ser representada) através de um mundo que não era seu. 0 logos mantinha e estabelecia a visão e a intenção do homem sobre o corpo da mulher, a respeito da alma da mulher, acerca de uma cultura, sociedade e economia - que não eram da mulher. A escrita por meio das mãos que perpetuaram a dominância do falogocentrismo procurou moldar o ser mulher no interior da linguagem patriarcal. Do falo à fala realmente feminina há, então, um hiato, que custou à literatura atravessar.

Maria Teresa Horta, em plena ditadura portuguesa, lançou-se a esse desafio, em uma escrita poética que lhe brota das entranhas do corpo, das cavidades mais íntimas em que se institui no mundo e na sociedade como mulher. Em ato libertário, escreve para ver a si prescindindo dos olhos do homem e da ideologia fascista do Estado Novo.

No governo de Marcelo Caetano, o regime opressor transpunha para a instância da família a lógica de uma sociedade organizada pelo medo, em que à mulher caberia a preservação do lar, metonímia da nação. Nessa perspectiva, a mulher deveria ser mãe, acima de tudo; o que lhe cabia era cuidar dos filhos e do marido, sua pequena pátria a defender. Sua vida sexual e seu desejo deveriam ser trancafiados dentro de seus corpos, sob o peso e a repressão da pátria: falar sobre isso era ultrapassar os limites da moral e da religião.

Do mesmo modo como essa mãe portuguesa, podemos pensar o discurso que ronda na sociedade tradicional todas as mães: as esposas-mães, as mulheres-mães, as amantes-mães, as irmãs-mães, as primas-mães, as rainhas-mães, as santas-mães, as putas-mães $\mathrm{e}$ as bruxas-mães.

Para a lógica machista, todas essas mães exercem sua função e nela se descontentam. Aquelas que recusaram a maternidade 
foram taxadas como histéricas, doidas, bandidas e banidas de uma convivência social porque lhes restava o lugar do ninguém: ao não serem mães, jamais conseguiriam a entrada no simbólico por meio da projeção de um falo próprio (o bebê). Essa é uma forma curiosa (para usar as palavras de maneira mais branda) de enxergar a mulher: como sua imagem na sociedade é a do não homem, carregada de negatividade, ela representa o papel que o homem lhe deu: o papel materno que lhe proporciona uma vida de cuidado e de castidade e lhe dá um arremedo do falo castrado, sob a forma de um filho. É apenas através do falo que a mulher alcança um status dentro da sociedade.

Contudo, isso não é ser mulher. E então, o que é ser mulher? Simone de Beauvoir (1980) afirma que não se nasce mulher, tornase mulher. Luce Irigaray (1985) assevera que a mulher, na entrada ao simbólico, já se relaciona com o mundo de forma diferente, por isso já é mulher - com o que Irigaray não pretende entrar no reino dos binarismos. Na verdade, essa entrada no simbólico, quando comparada com a entrada do homem, demonstra a multiplicidade e mobilidade da mulher. 0 gesto da mulher difere do gesto do homem e pode ser entrevisto, em sua dinâmica fluida no poema a seguir, em que a escrita de Maria Teresa Horta se constrói como movimento em direção a uma identidade, busca de si que não se cristaliza em um precipitado, mas faz ressoar, na própria significação, reverberações do tornar-se mulher.

\author{
Minha memória cetim \\ À minha mãe \\ Minha mãe \\ mulher-infância \\ meus cabelos revoltados \\ minhas longas pernas nuas \\ meu espelho desirmanado
}




\author{
Minha mãe \\ mulher-infância \\ com sua pele marfim \\ minha água de beber \\ minha memória \\ cetim \\ (HORTA, 1983, p.59).
}

A aproximação entre mãe e filha no poema é apresentada numa relação de similaridade, em que o hífen do neologismo "mulher-infância" funciona como espelho entre os vocábulos. 0 sinal diacrítico, enquanto lâmina refletora, faz da justaposição morfológica um processo de equalização, em que a semelhança entre as mulheres torna o laço mãe-filha mais forte.

É curioso o quanto essa união é vital, pois a mãe se torna "água de beber", ou seja, além de dar a vida, ela a mantém. A delicadeza desse laço se exprime na imagem "minha memória/cetim": o toque macio do tecido é traço mnêmico dessa relação, que se dá no nível da sensação e do sentimento. É na infância que esse vínculo se torna vital, ou seja, na entrada numa ordem simbólica que alça outros voos que não os da Lei do Pai.

Nessa perspectiva, Luce Irigaray (1985) afirma que se faz fundamental a percepção dessa outra ordem simbólica, não masculina, na qual a mulher viva em plenitude a partir de si mesma ou da identificação especular com a mulher primeira - a mãe. Em "Minha memória de cetim", essa dinâmica de reflexos e imagens se presentifica no verso "meu espelho desirmandado" e na própria estruturação das estrofes, em que os versos se relacionam por parataxe, e não hipotaxe. Sem subordinação sintática, as imagens de "Minha mãe", "mulher-infância" e "meus cabelos revoltados" se relacionam por similaridade, em que a filha, a mãe, a infância se tornam instâncias híbridas, no difuso e inefável ser mulher. Desse modo, o poema que se endereça à mãe, na figura do apóstrofe que o abre, pode ser lido como poema que se endereça à própria eu- 
lírica ${ }^{4}$, já que uma mulher é sempre todas as mulheres, constituídas no simbólico por essa identificação mútua.

Notemos: embora a entrada da mulher no simbólico seja diferente da do homem, ela é enlaçada pela história e cultura patriarcais de tal forma que não lhe é permitido vivenciar sua multiplicidade, de modo que ela acaba entrando nos moldes do simbólico masculino. É nesse ponto que Irigaray propõe toda uma mudança - quase uma luta solitária - para que a mulher se empodere como tal e consiga viver na mesma casa com o homem: uma casa de celebração da diferença.

Nessa mudança de ordem simbólica proposta por Irigaray, não se deveria relacionar a mulher ao falo, à falta; ou seja, à visão de que ela é mulher por não ser homem. Ela deveria ser vista como mulher, um sujeito completamente independente da subjetividade e objetividade biológica, social, econômica e histórica do homem. Belamente, ao descrever o simbólico feminino, Irigaray introduz a metáfora dos dois lábios: ao se tocarem, os lábios permitem uma série de prazeres que só são possíveis por haver dois, dois que representam um. Lábios que não se separam da boca, da língua, da fala, e portanto da poesia, como nos revela a lírica de Maria Teresa Horta.

É a partir desse movimento de se perceber, de entender a sua própria relação com o mundo, seu corpo e outros corpos, que a mulher conseguirá se desvencilhar das amarras do logocentrismo fálico e produzir um discurso embasado em si e em sua interação com o seu próprio simbólico. A mulher, por estar constantemente se tocando - uma vez que sua genitália possui um formato de dois lábios que estão em contínuo contato e não precisam de um

\footnotetext{
4 Termo aqui propositalmente flexionado no feminino, demarcando morfologicamente uma posição ética e estética. Afirmar que a mulher se insere na escrita não significa que Maria Teresa Horta em seu poema escreva suas experiências pessoais, e sim que transforma o seu ser em poesia. Há sim o corpo da mulher na escrita, mas este não é a materialidade do corpo da autora. 0 uso do termo "eu-lírico" nesse trabalho nos levaria a um apagamento do sujeito feminino e um enraizamento na lógica do falogocentrismo; portanto, subverter o termo e usá-lo num jogo de linguagem que o transforma em feminino realiza melhor o gesto crítico deste artigo.
} 
mediador para se tocarem (IRIGARAY, 1985) -, possui outras formas de relação consigo mesma que não são possíveis para o homem.

Irigaray relaciona a entrada da mulher no simbólico ao processo da fala, mas de uma fala que é emitida também como canção. Esse canto/fala vai se utilizar dos lábios inteiros e não de parte deles, como acontece no mecanismo do fort-da masculino. A partir dos lábios bucais, a interação da fala feminina se faz com todo o corpo, pois “os lábios são a própria mulher” (IRIGARAY, 1997, p. 183), em jogo erótico entre língua e cavidade bucal, lábios e cavidade genital - gozo a que se dá o poema a seguir:

A BOCA - OS LÁBIOS
A boca
os lábios
o labirinto dos dentes
que a saliva procura
na vagina da face
(HORTA, 2012, p. 92).

No poema "A Boca - Os lábios", a eu-lírica torna imagética essa multiplicidade do sentir feminino, em que todo o corpo está ligado às sensações e como um todo produz e recebe o gozo. Não se encaixa, portanto, na metafísica da presença e ausência masculinas, visto que não é a partir de um ponto único e ereto que a mulher experimenta o seu prazer, tal como o homem que goza centrado no falo.

0 poema exprime com primazia a relação dos dois lábios postulada por Irigaray (1985), pois estes são tanto os lábios bucais - por onde a mulher entra no simbólico com sua fala, sendo capaz de trazer algo de dentro para fora - quanto são os lábios vaginais, uma das várias possibilidades de prazer sexual feminino, num movimento de fora para dentro. 0 dístico da primeira estrofe, que encerra dois versos com mesma estrutura sintática (artigo definido e substantivo concreto), sublinha essa semelhança entre a boca e a vulva, de modo que os dois versos funcionem como o par de lábios que ensejam o beijo, a fala, o gozo na "vagina da face". 
Irigaray ressalta a importância da imagem dos lábios quando diz que

forçar uma mulher a falar ou forçar uma mulher deitada a abrir os lábios, a sair de si mesma, pode representar uma violação analítica. A mulher não está protegida pelo mecanismo do fort-da, pela maneira como este está constituído por divisões de tempo, de espaço, do outro, do eu, por suas divisões fonéticas. Com muita frequência ela é incapaz de se expressar, a não ser que, para começar, seus lábios novamente toquem um no outro e ela movimente o corpo todo. (IRIGARAY, 1997, p. 184).

Portanto, quando os lábios se movem, mexem com todo o corpo e, quando uma mulher fala, espontaneamente, ela se diz por inteira, entregando-se no ato do dizer. 0 corpo da mulher, como estrutura, assemelha-se então ao poema, em que o todo ultrapassa a soma das partes e tem uma dimensão intangível, que a interpretação, o amor, a exegese tentam fazer falar.

Ainda no poema "A boca - os lábios", a interação de todo o corpo se faz presente, pois, embora os lábios estejam distantes como partes do corpo, são boca e vagina ao mesmo tempo; já não importa onde o corpo se toca, pois o toque é total. A metáfora apresentada como a "vagina da face" é fortemente marcada por uma sexualidade feminina devoradora, uma vez que os dentes nos remetem à imagem da mastigação, trituração. Mas eles aqui se apresentam como labirintos percorridos pela saliva, aproximando o ser feminino ao elemento aquático de onde sua fluidez emana. A mulher, como um rio, não pode ser contida numa margem - a mulher transborda no gozar.

Cabe lembrar aqui que a "vagina dentada" é arquétipo que aterroriza os homens pelo seu poder de castrá-los. No entanto, se observarmos mais atentamente esse órgão erógeno feminino, podemos entendê-lo em relação a si próprio - e não como em função (ou oposição) do falo a ser castrado -, na circularidade que é característica da mulher. Observar o corpo da mulher em 
relação a ele próprio retira-lhe a função que exerce no mundo do falo: a vagina dentada não servirá de reguladora sexual masculina e não representará a mulher como descontrolada sexualmente devoradora de homens. A vagina não pertence à Lei do Pai.

Podemos observar essa relação da vagina estritamente com o corpo feminino, ainda que numa perspectiva do devorar, no poema a seguir:

\author{
A VAGINA \\ É cálida flor \\ e trópica mansamente \\ de leite entreaberto às tuas mãos \\ Feltro das pétalas que por dentro \\ tem a felpa das pálpebras \\ da língua a lentidão \\ Rosa do corpo \\ pulmão que não respira \\ dobada em cuspo tecida a sua água \\ Flor carnívora voraz do próprio suco \\ no ventre entorpecida \\ nas pernas sequestrada \\ (HORTA, 2012, p. 117).
}

Iniciado pelo verbo "ser", o corpo do poema se inscreve como explicação ou definição do seu título, movimento metalinguístico em que, por meio da poesia, a mulher busca entender a si, seu sexo, parte de si que lhe foi alienada pelo olhar fetichista e repressor de um outro que a oprime. Nessa perquirição por um significado da vagina, o poema a descreve por meio de imagens altamente sinestésicas, em que a eu-lírica prioriza o sentido do tato nas texturas, temperaturas e movimentos, aumentando a carga erótica da lira sem recair na pornografia que separa a mulher de seu sexo e a reifica para consumo alheio. 
No poema, a vagina é representada de forma ambivalente, entre a flor mansa e a boca ávida, instâncias que se encontram no último verso, na imagem da flor carnívora. Úmida, macia e cálida, a flor bucal - ou boca floral - é vagina que seduz e acaricia; todavia, o objeto da carícia é aqui o próprio corpo da mulher, num movimento reflexivo e autoerótico que se entrevê nos versos "dobada em cuspo tecida a sua água", "no ventre entorpecida" e "nas pernas sequestrada".

Desse modo, o que a flor devora no poema não é o pênis, como no mito da vagina dentada. Ela existe para si mesma, e não para ameaçar o homem; logo, é do seu próprio suco que tal vagina é voraz. Sorver a si mesma é lamber-se na língua - e no verso -, num exercício de a mulher olhar a si própria na instância do poema: "tem a felpa das pálpebras/ da língua a retidão".

Não estando a ferocidade da flor-vagina ligada a uma regulação sexual com o homem, mas sim ao corpo da própria mulher, a busca por uma identidade na escrita feminina devém uma fome de si. Tal necessidade de seu corpo se transfere para a poesia, do mesmo modo como Hélène Cixous (1987) proclama que a mulher deve se escrever com todo o seu corpo.

A mulher deve se escrever: deve escrever sobre mulher e trazer a mulher para a escrita, de onde elas foram retiradas tão violentamente quanto de seus corpos pelas mesmas razões, através da mesma lei, e com o mesmo objetivo fatal. A mulher deve se colocar no texto como no mundo e na história - por sua própria ação. (CIXOUS, 1987, p. 320).

Ou seja, é através de si mesma, do conhecimento do seu próprio corpo, do autoerotismo e do seu preciso - e precioso - ser que a mulher deve elaborar sua escrita, para que dessa forma ela seja inserida na história por meio do que é e não da forma em que é representada pelos homens. A escrita feminina, como escrita do corpo, torna-se uma ferramenta de empoderamento da mulher, em que esta se afirma numa nova linguagem. 
Contudo, quando o corpo feminino é definido através de um modelo falogocêntrico, seu valor fica inscrito nos de uma sociedade patriarcal, onde o que importa é a propriedade, o domínio dos meios de produção, a ordem, a forma, a ereção (IRIGARAY, 1985). É a dinâmica do sólido e não da fluidez que domina no falocratismo.

É dentro dessas tradições falogocêntricas que a psicanálise tradicional entende o desenvolvimento da sexualidade feminina. Logo, segundo Irigaray (1985), na leitura psicanalítica conservadora, não haveria dois sexos, mas apenas um, de modo que a sexualidade feminina seria definida, modelada e inserida dentro das exigências da sexualidade masculina. Nessa perspectiva, tudo o que se refere à mulher se define pelo complexo de castração, pois não haveria uma superação do complexo de Édipo, da inveja do pênis, e ter um filho seria supostamente a única forma de preencher o vácuo causado pela falta do falo.

Quando Lacan leva a psicanálise para o nível do discurso, revela-nos que é na linguagem que se estabelecem as questões da sexualidade, transformando a maneira de enxergar o ser humano. Contudo, Irigaray (1985) não nos deixa esquecer que tais leis da linguagem foram por séculos também definidas pelos homens; fascista (BARTHES, 1994), a linguagem tradicional existe dentro dos padrões masculinos definidos ao longo da existência da humanidade.

Irigaray, para explicar essa visão da psicanálise, cita Lacan e seu seminário XX:

Não há mulher que não esteja excluída da natureza das coisas, que é a natureza das palavras, e temos que dizer que, se há algo que elas lamentem bastante no momento, é mesmo disso - exceto que elas não sabem o que estão falando, esta é toda a diferença que há entre elas e eu. (LACAN apud IRIGARAY, 1985, p. 87).

Quando Lacan diz que as mulheres não sabem o que dizem, é pelo fato de que elas não possuem um lugar privilegiado na linguagem: 
a mulher não existiria na linguagem, embora esteja dentro dela. Há algo no mundo feminino e no seu prazer que escapa à compreensão da lógica linguística. A exclusão feminina seria então inerente à linguagem e por esse motivo a mulher é uma ameaça: ela desafia a ordem pela potência em subvertê-la.

Segundo tal perspectiva, no simbólico a mulher é um "not-all" (não toda), uma vez que o todo é o homem. Ela não é e não vai ser sujeito, não entra num molde universal, a menos que adquira e se entranhe nas necessidades masculinas e a partir delas se defina no único lugar que lhe resta: o da mãe. A necessidade de possuir o falo - a inveja do pênis - representaria a vontade feminina de entrar na ordem simbólica, mas ela só faz parte dessa ordem quando abre mão da sua feminilidade. Dessa forma, seria como se, quando a mulher entrasse no simbólico, perdesse suas características femininas, a ponto de não existir de forma corporal. Ela não seria definida afirmativamente pelo corpo e sim negativamente por essa falta que representa na linguagem.

Nessa descorporeificação da mulher, sua sexualidade é deixada de lado no discurso, uma vez que ela atende às necessidades masculinas. Já não interessam quais são as regiões erógenas das mulheres, pois elas, em verdade, não existem: a mulher não sabe falar sobre o prazer, uma vez que não compreende a linguagem; a ela falta a palavra.

E quando se fala na vivência do prazer, o "Um", ou o todo, só sentiria prazer ao conhecer as partes do corpo do "Outro" que não fazem parte do seu. Logo, a mulher precisa ser mutilada, cortada em partes, a fim de que se torne interessante o suficiente para entrar no mundo da significação. Note-se, porém, que aqui não estamos falando da multiplicidade do corpo feminino; expressamos a sua mutilação, dilaceração. Ele é dividido pelo homem (não múltiplo de sentidos e gozo da mulher). Não haveria, pois, a mulher como unidade, e sim como o que falta. Não haveria dois sexos (o homem e a mulher), e sim apenas um: o homem e o não homem.

A mulher não teria um lugar de prazer a não ser aquele que 
o homem desejasse lhe conferir. Ou seja, "a mulher não tem inconsciente, exceto aquele que o homem lhe confere" (IRIGARAY, 1985, p. 93-94). A sexualidade da mulher, em última instância, além de ser pautada na única possível - a masculina - depende exclusivamente da intervenção do homem para que aconteça. E esse desejo do homem é o desejo de ter a mãe, o útero da mãe, possuir a origem de si, permitindo-se continuar.

Mulher como útero, o útero inconsciente da linguagem do homem: por si própria, ela não teria relação com o "seu" inconsciente, exceto aquele que seria marcado por uma desapropriação essencial. Na falta, no êxtase... e no silêncio. (IRIGARAY, 1985, p. 94).

Apenas no papel de mãe, através da gestação e de ter suas crianças, a mulher consegue se inserir novamente nessa sociedade masculina. A mulher está livre (?) das relações e realizações sexuais; não faz parte delas, porque sua única função é ser a mãe - livre de prazeres. Ela é o útero que satisfaz as necessidades masculinas de existência, de linguagem, e através do seu útero os homens lhe conferem a "feminilidade". Ela é o receptáculo, o cálice, reservatório que garante a continuação masculina - um espaço do homem, enfim.

Dentro dessa lógica falogocêntrica, por meio da qual as mulheres são separadas umas das outras, são analisadas uma a uma, para que lhes seja impossibilitada a noção de um todo uno onde seja possível um novo discurso, uma nova linguagem. "A falta de acesso ao discurso no corpo do Outro é transformada em intervalos que separam todas as mulheres umas das outras" (IRIGARAY, 1985, p.98). Negada à mulher a possibilidade do autoerotismo, ela só sente como o outro - na lógica da mesmidade. Ela, portanto, não tem voz, não tem corpo e não possui a palavra, situação contra a qual se insurge a eu-lírica no poema a seguir. 


\title{
FAZER O POEMA
}

\author{
Desfio a poesia \\ no baraço \\ do peito \\ Na curva da cintura \\ em fogo-fátuo \\ Pois na cama \\ é poema e é papel \\ Para logo ser \\ gemido \\ corpo e queira \\ Chegar na palavra \\ e naquilo que rasgo \\ Verso a verso ao topo \\ do orgasmo \\ (HORTA, 2012, p. 275).
}

No poema acima, a eu-lírica reclama o local da linguagem e do corpo como presença. Nesse processo, desafia a lógica masculina do discurso ao desfiar a própria poesia que existe dentro de si, e este é um desafio que se encarna no corpo - é a poesia manifestação de seu autoerotismo, dando-se no espaço da cama e do papel. Desafiar a poesia se torna, então, uma atividade vital e orgânica, busca de algo que se confunde com a chegada e o orgasmo, gozo de quem seguiu "verso a verso ao topo" em busca do "gemido/corpo e queira" do poema.

Encontrar a poesia em si é resistir às imposições de ordem masculina, o que só pode se dar na luta e na lida com a linguagem, em que se "desfi[a] a poesia/no baraço do peito". Note-se, nesse verso, a ambiguidade do substantivo "baraço", que pode significar tanto um cordel mais espesso de fios do qual se desenleia a poesia quanto um relho para açoite ou uma corda para enforcamento (HOUAISS, 
2009), o que torna ainda mais dramática a busca tematizada no verso.

A eu-lírica desafia a poesia numa necessidade de encontrar sua própria voz, que não é tomada pela linguagem masculina. Para isso, é necessário ao mesmo tempo revelar a total articulação da mulher com sua linguagem - uma linguagem que fica repleta de vazios e de incompletudes. Estes só podem ser preenchidos com o corpo, quando, "na curva da cintura", a escuridão (ou ausência) devém brilho (ou presença), iluminada pelo fogo fátuo da segunda estrofe.

A sexualidade intrincada nesse processo transforma o poema e a sua matéria de permanência - o papel - em local de prazer, pois na cama se transformam em gemidos as palavras da poesia. Mais uma vez, o prazer feminino se faz múltiplo, se transforma e toma para si todos os espaços que lhe são palpáveis. Ao chegar a essa palavra, aquela que a define, que lhe dá nome, a mulher rasga tudo, transforma o verso a partir da sua fúria e da sua necessidade de não definição no mundo falogocêntrico.

A palavra não é suficiente para expressar-se, para dizer do seu gozo; por isso, a mulher desfaz-se dela. Nessa rebeldia e nessa não definição a partir do masculino, o orgasmo feminino se alcança. Através da sua linguagem e do domínio dela, em paralelo à recusa ao logos fálico, a mulher encontra mais um ponto de prazer. Suas margens não são definidas e o gozo se manifesta em tudo o que a mulher faz, refaz e não faz. A escrita se torna local de prazer - é poema e é papel - e possibilita a permanência material de uma marca do feminino, que se deixa ver desde a conformação morfológica do corpo.

Quando Irigaray (1985) discute o que seria a linguagem feminina, assevera que esta está completamente ligada à corporeidade; contudo, a autora apresenta a impossibilidade de definição do que seja exatamente essa linguagem. Afinal, ao defini-la usando uma sintaxe e um léxico caros à Teoria da Literatura ou da Linguística, instituições sobretudo acadêmicas, mais uma vez estaríamos no reino da tradição e do falogocentrismo, aprisionando a significação sob um ditame machista do signo. 
O que se pode dizer, então, é que a escrita feminina se entrevê mais por sua constante transformação numa economia da fluidez do que por sua materialidade do significante, como nos poemas de Maria Teresa Horta aqui analisados. 0 falar (como) mulher pode ser observado quando há sofrimento (momento em que a mulher se entrega a si mesma), mas também quando há risada e quando a mulher se encontra entre mulheres (IRIGARAY, 1985) e o discurso corre, livre, nos meandros do corpo. Nesses momentos, pode haver a possibilidade de um distanciamento da linguagem masculina para uma apropriação da imanência da voz, da fala da mulher.

Mas escrever nessa sintaxe, nessa fluidez - que é muito próxima à da fala -, é algo que requer uma disciplina muito intensa - uma disciplina no sentido de se libertar de todas as imagens do "reino do imaginário masculino" (IRIGARAY, 1985, p. 135). Nesse sentido, a escrita feminina ressoa justamente no não dito, na fenda - neste intervalo onde a mulher se diferencia do homem e não significa a partir dele. Como todo corte, esse precisa ser aberto - e assim mantido - à custa de uma violência; talho que é, exige uma incisão linguageira no simbólico para fazer esvair e fluir o sentido do ser mulher.

\author{
VIOLÊNCIA \\ Ó secreta violência \\ dos meus sentidos domados \\ em mim parto \\ e em mim esqueço \\ senhora do meu \\ silêncio \\ com tantos quartos fechados \\ Anoitece e desguarneço \\ despeço \\ aquilo que faço
}




\section{Ó semelhança firmeza mulher doente de afagos}

(HORTA, 2007, p. 61).

Neste poema de Maria Teresa Horta, a violência que lhe dá título é também interlocutora, a que a eu-lírica se dirige por meio de dois apóstrofes: "Ó secreta violência/dos meus sentidos domados" e "Ó semelhança firmeza/mulher doente de afagos". Mais do que medo, trata-se de violência que dá segurança, pois a mulher aqui não é vítima do ato violento; trata-se da violência que a mulher perpetra para se afirmar na linguagem, por meio de um corte que lhe abre um espaço para ser.

Ademais, é essa violência que escoria a superfície textual, abrindo-lhe intervalos entre as palavras e os versos, para que a mulher possa significar. Esta se inscreve violentamente no desejo do corpo a fim de libertar seus "sentidos domados" - libido que o patriarcado silencia sob a imagem da mãe virgem. Nesse sequestro de seu gozo, a mulher entra num jogo de "máscaras" (masquerade), em que a realidade acaba sendo invertida e o jogo se torna o que é real, de modo que aquilo que seria essencialmente feminino é perdido e deixado de fora do discurso. Mas é exatamente nesse silêncio que a mulher recupera sua feminilidade, pois ela se entende ainda que continue trancafiada: "senhora do meu/silêncio/com tantos quartos fechados".

Quando se encontra sozinha, ela se liberta das amarras da sintaxe masculina e consegue se sentir e se entender como mulher, o que culmina poeticamente no texto acima em construções estranhas à sintaxe padrão - mas altamente significativas -, como a justaposição de "semelhança firmeza" ou a locução "em mim parto". Nesse processo de autoconhecimento na solidão e no vazio, a mulher se lança em uma jornada cada vez mais para dentro de si, denotada pelos verbos "partir" e "despedir", abrindo sua jornada, à força, no próprio corpo. Essa é a violência da escrita feminina, ou do falar (como) mulher. 
Cixous (2007) também enxerga na escrita o caminho para que a mulher se apodere de seu próprio corpo: "Escreva! Escrever é para você, você é para você, o seu corpo é seu, apodere-se dele" (CIXOUS, 2007, p. 320). A esse respeito, a autora assevera que, apesar de a escrita da mulher não vir a público no passado, ela já escrevia, assim como se masturbava silenciosamente, no espaço do "escondido". Tal qual o orgasmo, a escrita lhe proporcionava o sentimento de culpa, co-habitando o território do interdito.

O erótico, segundo Lorde (1984), está presente em todos os aspectos da nossa vida e negá-lo é perder a capacidade de ser plena, de se conhecer e ser feliz. Render-se a um estigma ou a uma imposição sobre o corpo é não poder gozar e se entregar ao pornográfico - ter o desejo usado por outro. Logo, a escrita também deve apoderar-se do uso do erótico e, através desse corpo que fala (e canta e dança e grita e ri!), ela pode se tornar feminina, desde que não siga reproduzindo o corpo confinado na mentalidade falocêntrica.

É a partir da sua escrita, como assevera Cixous (2007), que a mulher recupera o corpo que lhe foi confiscado. Ela se reconecta com sua própria sexualidade e se torna uma guerreira de si mesma, ao invés de lutar por uma batalha que não é sua. A escrita feminina como escrita do corpo é uma forma de empoderamento feminino que leva a mulher a se apropriar de seu discurso e fazê-lo político.

A mulher fala de si e para si, fala com outras mulheres numa linguagem sua e que não é compreensível para o homem, pois ela está fora da linguagem - é a "não-toda" - e fala com o corpo. Suas palavras são "balbucios" e nesse sentido se aproximam da fala da criança para quem o som e sua articulação com o corpo têm um significado que vai além da linguagem oral (BRANCO; BRANDÃO, 2004). Sua fala faz parte de uma linguagem pré-verbal, e essa reaproximação com um caráter originário da fala e da língua, em que as palavras recobram a corporeidade da enunciação, sublinha o estatuto poético da escrita feminina.

É nessa fala pré-verbal e corporal que a escrita feminina falará 
do corpo da mulher, através do corpo da mulher. Transferir essa linguagem, esse falar (como) mulher, para a obra escrita é levar ao nível do incompreensível a palavra grafada, é transformar a palavra para ressignificar o corpo feminino " $\mathrm{E}$ é no momento em que a linguagem verbal se cala que o corpo da personagem invade a cena, por meio da tentativa exaustiva da narradora de reconstituílo, de restaurá-lo." (BRANCO; BRANDÃO, 2004, p.153). Aqui, se substituída a voz enunciadora da narração (narradora) pela voz enunciadora do poema (eu-lírica), pode-se entender como Maria Teresa Horta se torna todas as mulheres ao assumir o lócus de instância poética, dizendo de uma experiência que a transcende e a constitui.

Nesse processo, a escrita feminina não pretende comunicar, ela reivindica ser. Não há mensagem a ser passada, não há signos a serem decifrados: o corpo se diz, não informa. Ele expressa a si na linguagem feminina sem pretender com isso ser entendido intransitividade da literatura de que Barthes (1994) já falara. A multiplicidade da Outra mulher transcende o seu corpo e abarca tudo o que a voz lírica enuncia. Assim, a escrita feminina almeja "ao lado de um sujeito que não chega a ser, à margem de um discurso que não visa a comunicar, em torno de uma escrita - inscrição que pretende dizer o indizível." (BRANCO; BRANDÃO, 2004, p.157). Aporética, essa inscrição melhor se faz na metáfora do poema do que no discurso acadêmico; logo, recorramos à lira de Maria Teresa Horta para experimentar a escrita feminina em ato.

\author{
ANTECIPAÇÃO \\ Entreabro as minhas \\ coxas \\ no início dos teus beijos \\ imagino as tuas \\ pernas \\ guiadas pelo desejo
}




oiço baixo o teu
gemido
calado pelos meus dentes
imagino a tua boca
rasgada
sobre o meu ventre
(HORTA, 2007, p. 74)

A pré-linguagem coabita o espaço da antecipação: é o prenúncio na pele do que vai acontecer. Nesse processo de adivinhar o que virá a ser, a eu-lírica habita o corpo de desejo e as sensações provocadas pela antecipação - tal qual o título que precede, suscita, mas não define o corpo do poema. Mais do que palavras, "Antecipação" vai desabrochando sensações múltiplas que não se concentram num órgão - ou verso - específico. É com o corpo inteiro que a eu-lírica sente: são as coxas ligadas ao beijo, a boca que conduz pelas pernas, o desejo que se mistura com a audição, o gemido que vem da região do indizível, daquilo que é apenas som - e não significante -, mas que é calado pela corporalidade dos dentes.

Nesse poema, a linguagem não é matéria-prima da imagem; ela é construída como imagem do corpo. 0 enjambement entre os versos é então articulação sintática e anatômica, com que a falta de sinais de pontuação colabora, sugerindo a fluidez e a circularidade do desejo feminino, sem entraves. Se o desejo não reconhece limites, não deve também a linguagem estabelecê-los, de modo que só como pré-linguagem - infensa à castração ou à adoração do falo - pode a escrita feminina se construir. Gemido calado, imaginado, é sempre significação fugidia, condição do sentido que não se quer absoluto.

A imaginação presente desce até o ventre. Através da palavra escrita, sente-se a pulsação do desejo que, antevisto ainda na esfera da não presença, já faz gemer. É “um gozo de um corpo que goza a si mesmo" (GABRIEL, 2009, p. 47).

Essa escrita feminina que se faz impossível de ser captada, domada e classificada é justamente ferramenta do indizível da 
mulher, aqui analisada na pena de Maria Teresa Horta. Trata-se, pois, de feminino que não pode ser contido em um quarto escuro, que não teme a lacuna e que é turbilhão lírico: letra, corpo e gozo.

\section{Considerações finais}

A escrita feminina não se quer passível de uma apreensão final de significado ou de uma definição que circunscreva seus limites estéticos, até porque delimitar e segregar são estratégias do patriarcado que marginalizaram, ao longo dos séculos a mulher. É como gozo, sempre inefável e fugidio, que essa linguagem deve ser entendida, cabendo-nos sobretudo fruí-la para melhor entendê-la, como aqui fazemos no diálogo entre a teoria feminista e a lira de Maria Teresa Horta.

Na produção poética da autora portuguesa, observamos a ressignificação do ser mulher, como sujeito de seu corpo e seus desejos, perquiridos numa busca de si no seio da poesia. Sua escrita feminina, construída não como negativa do masculino - e sim como afirmação de mulher -, enseja uma série de reflexões teóricas, que se buscou alinhavar no presente artigo.

À guisa de conclusão, encerra-se aqui o fio argumentativo, mas na ciência de que todo fim ou divisa é arbitrário, como bem nos ensina o feminismo. Na superação dos limites, o ser mulher transborda as fronteiras estipuladas pelo falocentrismo e por isso sua escrita se torna subversiva. Ela usa as ferramentas masculinas e de dentro delas faz com que suas bordas sejam alargadas, remodeladas, e isso tudo para transcendê-las. A mulher múltipla não teme o abismo que o falocentrismo lhe atribuiu por se saber transbordante.

Nós somos tempestuosas, e isto que é nosso se liberta de nós sem nosso temor de alguma debilidade. Nossos olhares, nossos sorrisos são gastos; risadas exsudam de nossas bocas; nosso sangue flui e nós nos estendemos sem jamais alcançar um fim; nós nunca seguramos nossos pensamentos, nossos signos, nossa escrita; e nós não temos medo da falta. (CIXOUS, 2007, p. 322). 
Dessa forma a mulher fala, Maria Teresa Horta fala e a eu-lírica devém nós-líricas: uma mulher é sempre todas as mulheres.

\section{Referências bibliográficas}

BARRENO, M. I.; COSTA, M. V.; HORTA, M. T. Novas cartas portuguesas. São Paulo: Abril (Círculo do Livro), 1974.

BARTHES, R. Aula. São Paulo: Cultrix, 1994.

. Crítica e verdade. São Paulo: Perspectiva, 2011.

BEAUVOIR, S. de. 0 segundo sexo. v.I, II. Rio de Janeiro: Nova Fronteira, 1980.

BRANCO, L. C.; BRANDÃO, R. S. A mulher escrita. Rio de Janeiro: Lamparina editora, 2004.

CIXOUS, H. The Laugh of the Medusa. In.: FREEDMAN, S. B. The essential feminist reader. New York: Modern Library. 2007.

. The newly born woman. Minneapolis: University of Minnesotta Press, 1987.

DERRIDA, J. Dissemination. Chicago: University of Chicago Press, 1981.

GABRIEL, A. B. A casa da diferença. 106 f. Monografia (Mestrado em Filosofia). Instituto de Humanidades. Universidade de Brasília. Brasília. 2009. 
HORTA, M. T. As Palavras do Corpo (Antologia de Poesia Erótica). Lisboa: Publicações Dom Quixote, 2012.

. Minha Senhora de Mim. Lisboa: D. Quixote, 1971.

.Palavras Secretas. São Paulo: Escrituras Editora, 2007.

Poesia Completa. Lisboa: Litexa, v.1 e 2, 1983.

HOUAISS, A. HOUAISS eletrônico. Versão Monosuário 3.0. Editora Objetiva, 2009.

IRIGARAY, L. 0 gesto da psicanálise. In.: BRENNAN, Teresa (org). Para além do falo: uma crítica a Lacan do ponto de vista da mulher. Rio de Janeiro: Record/Rosa dos Tempos, 1997.

. This sex which is not one. Ithaca, New York: Cornell University Press. 1985

LORDE, A. Uses of the Erotic: The Erotic as Power, In: Sisters Outsider: essays and speeches. New York: The Crossing Press Feminist Series, 1984. P. 53-594.

SPIVAK, G. C. 1988b. 'Can the Subaltern Speak?' in. Nelson C. and Grossberg, L. (eds.) Marxism and the Interpretation of Culture. London: Macmillan, pp. 271 - 313. 